
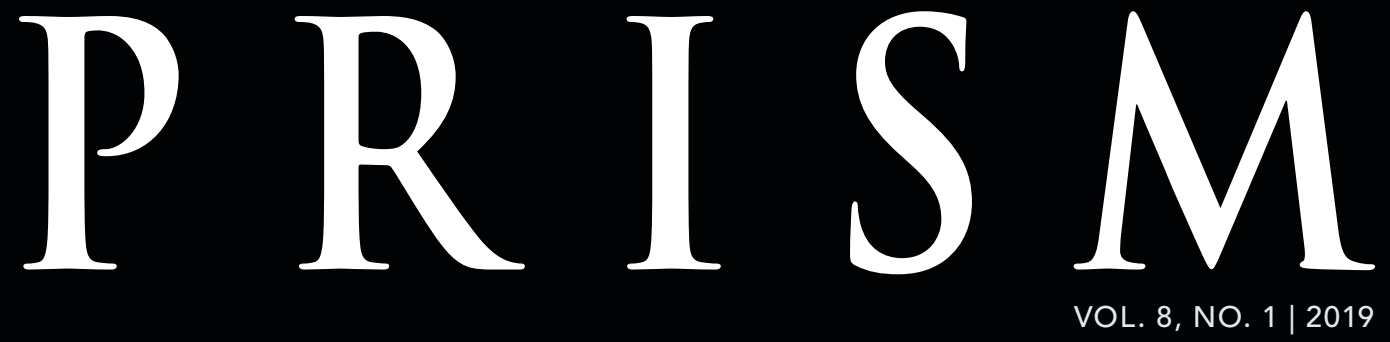

\title{
SECURITY IN THE WESTERN HEMISPHERE
}

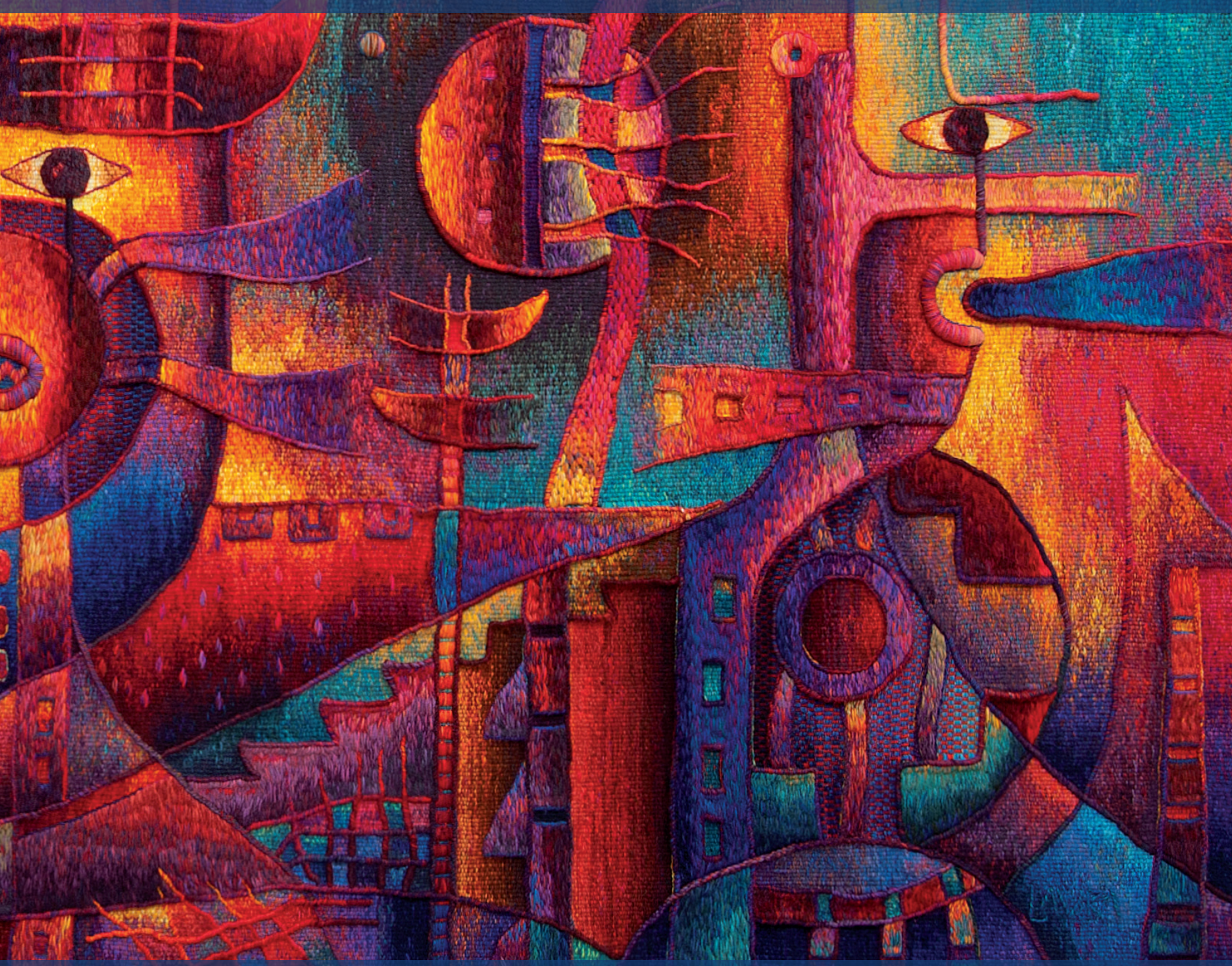

THE JOURNAL OF COMPLEX OPERATIONS 


\section{PRISM}

VOL. 8, NO. 12019

\section{EDITOR}

Mr. Michael Miklaucic

\section{DEPUTY EDITOR}

Ms. Patricia Clough

\section{ASSOCIATE EDITOR}

Mr. Dale Erickson

\section{INTERNET EDITOR}

Ms. Joanna E. Seich

\section{DESIGN}

Ms. Jamie Harvey,

U.S. Government Publishing Office

\section{EDITORIAL BOARD}

Dr. Gordon Adams

Dr. Pauline Baker

Ambassador Rick Barton

Dr. Alain Bauer

Dr. Hans Binnendijk

ADM Dennis Blair, USN (ret.)

Ambassador James Dobbins

Dr. Francis Fukuyama

Ambassador Marc Grossman

Ambassador John Herbst

Dr. Laura Junor (ex officio)

Dr. David Kilcullen

Ambassador Jacques Paul Klein

Dr. Roger B. Myerson

Dr. Moisés Naím

Ambassador Thomas Pickering

Dr. William Reno

Lt. Gen. John F. Sattler, USMC (ret.)

Dr. James A. Schear

Dr. Joanna Spear

ADM James Stavridis, USN (ret.)

Dr. Ruth Wedgwood

\section{ABOUT}

PRISM, the quarterly journal of complex operations published at National Defense University (NDU), aims to illuminate and provoke debate on whole-of-government efforts to conduct reconstruction, stabilization, counterinsurgency, and irregular warfare operations. Since the inaugural issue of PRISM in 2010, our readership has expanded to include more than 10,000 officials, servicemen and women, and practitioners from across the diplomatic, defense, and development communities in more than 80 countries.

PRISM is published with support from NDU's Institute for National Strategic Studies (INSS). In 1984, Secretary of Defense Casper Weinberger established INSS within NDU as a focal point for analysis of critical national security policy and defense strategy issues. Today INSS conducts research in support of academic and leadership programs at NDU; provides strategic support to the Secretary of Defense, Chairman of the Joint Chiefs of Staff, combatant commands, and armed services; and engages with the broader national and international security communities.

\section{COMMUNICATIONS}

PRISM welcomes unsolicited manuscripts from policymakers, practitioners, and scholars, particularly those that present emerging thought, best practices, or training and education innovations. Publication threshold for articles and critiques varies but is largely determined by topical relevance, continuing education for national and international security professionals, scholarly standards of argumentation, quality of writing, and readability. To help achieve threshold, authors are strongly encouraged to recommend clear solutions or to arm the reader with actionable knowledge.

Our review process can last several months. The PRISM editorial staff will contact authors during that timeframe accepting or regretfully rejecting the submission. If the staff is unable to publish a submission within four months of acceptance, PRISM will revert publication rights to the author so that they may explore other publication options.

Constructive comments and contributions are important to PRISM. We also welcome Letters to the Editor that are exclusive to PRISM - we do not publish open letters. The PRISM editorial staff will contact authors within two months of submission if they accept the letter for publication.

Please direct all electronic comments and contributions to <prism@ndu.edu $>$. Hard copies should be sent to the address listed below and include a note that highlights a preferred phone number and email for feedback; PRISM does not return original hard copy submissions.

\author{
National Defense University \\ Deputy Editor, PRISM \\ 260 Fifth Avenue, S.W. \\ Suite 2500 \\ Fort Lesley J. McNair \\ Washington DC 20319
}

\section{DISCLAIMER}

This is the authoritative, official U.S. Department of Defense (DOD) edition of PRISM. Any copyrighted portions of this journal may not be reproduced or extracted without permission of the copyright proprietors. PRISM should be acknowledged whenever material is quoted from or based on its content.

The opinions, conclusions, and recommendations expressed or implied within are those of the contributors and do not necessarily reflect the views of DOD or any other agency of the Federal Government, or any other organization associated with this publication.

As this edition went to press, the political situation in Venezuela remained dynamic and uncertain. On January 23, 2019, U.S. Secretary of State Michael R. Pompeo issued a press statement declaring that the United States "recognizes Juan Guaido as the new interim President of Venezuela, and strongly supports his courageous decision to assume that role pursuant to Article 233 of Venezuela's constitution and supported by the National Assembly, in restoring democracy to Venezuela."

\section{COVER ART}

Maximo Laura, "Inner Cosmos," Alpaca wool, mixed fiber hand-woven Peruvian tapestry. Reproduced with permission by the artist. 


\section{SECURIT Y IN THE WESTER N H M ISPHERE}

\section{FEATURES}

2 Defending Democracy and Human Rights in the Western Hemisphere

By Luis Almagro

12 The Strategic Price of Neglect

By Peter Schechter

26 The U.S. Military in Support of Strategic Objectives in Latin America and the Caribbean By R. Evan Ellis

40 The Venezuelan Crisis and Salvador Allende's Glasses

By Juan S. Gonzalez

56 The Evolution of the Most Lethal Criminal Organization in Brazil-the PCC

By Leonardo Coutinho

68 Great Expectations and Grim Realities in AMLO's Mexico

By Mary Speck

82 Security Challenges of the New Colombian Administration

By David E. Spencer

96 Extra-regional Actors in Latin America: The United States is not the Only Game in Town By Douglas Farah and Kathryn Babineau

114 Only Connect: the Survival and Spread of Organized Crime in Latin America By Ivan Briscoe and David Keseberg

132 The New Opium War: A National Emergency

By Celina B. Realuyo

\section{BOOK REVIEWS}

143 China's Strategic Partnerships in Latin America: Case Studies of China's Oil Diplomacy in Argentina, Brazil, Mexico, and Venezuela 1991-2015

Reviewed by William H. Godnick

146 Soldiers, Politicians, and Civilians: Reforming Civil-Military Relations in

Democratic Latin America

Reviewed by Craig Deare 


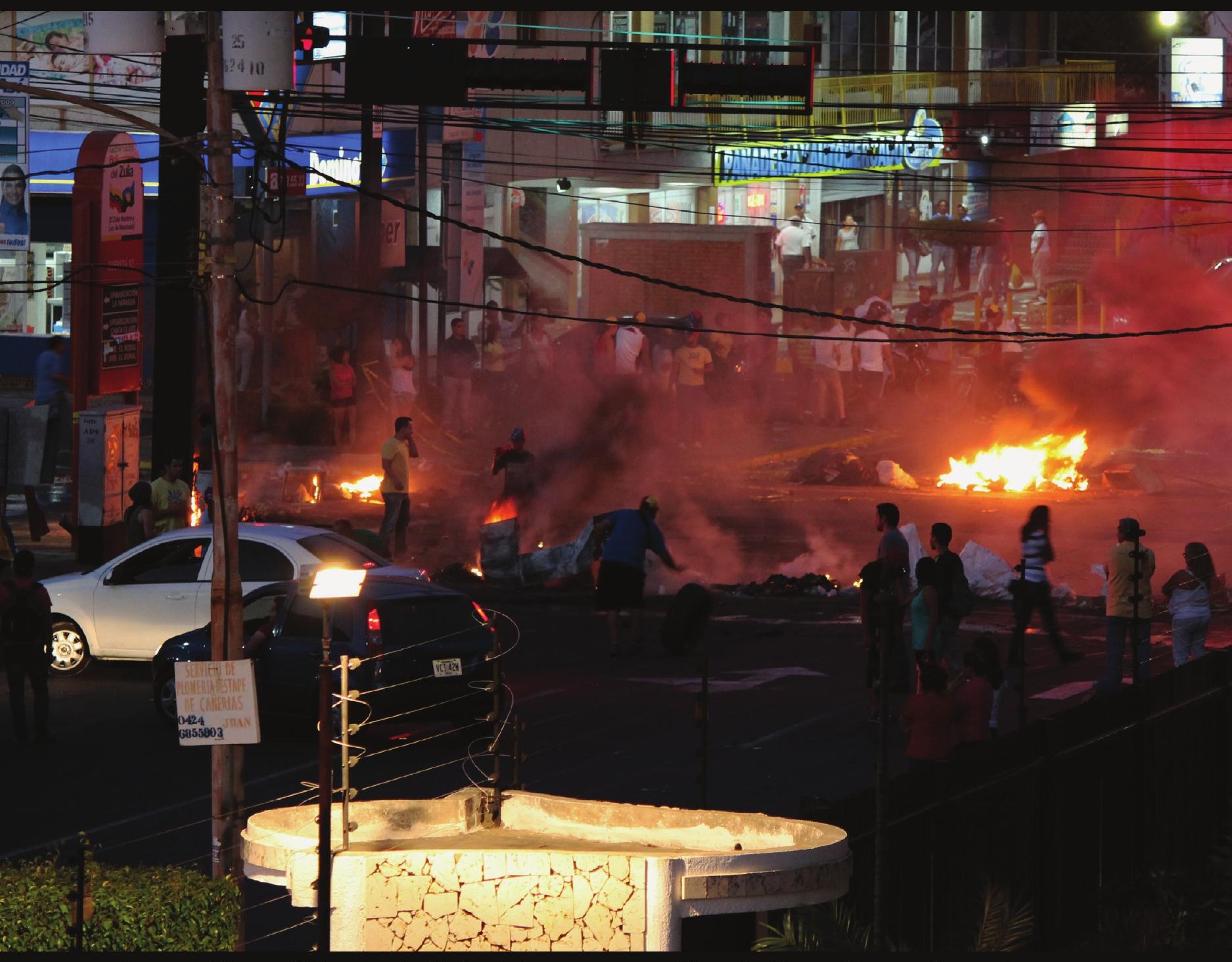

Protests in February 2014 against the Nicolas Maduro government in Maracaibo, Venezuela's second largest city. (Wikimedia/Name withheld at request of copyright owner) 


\section{Defending Democracy and Human Rights in the Western Hemisphere}

By Luis Almagro

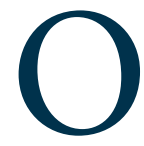
ne glimpse at the covers of the main news and political magazines in recent years is often enough to discern a common theme. These publications often display fatalist titles such as "Democracy in Demise," "Democracy in Crisis," "Democracy in Peril," or maybe the alternative favorite, "Authoritarianism on the Rise." First the 2008 financial crisis, then the results of certain elections worldwide led many to question the future of liberal democracy. In Latin America, an additional series of events such as the "Operacão Lava Jato" (Operation Car Wash) corruption scandal that put many high-level elected and public officials in jail, paved the way for fed-up citizens to rebel against their governments in the streets and in the polls, ousting traditional parties and political elites from power.

Despite the bad news, and the serious backsliding in some specific cases and notorious exceptions (e.g. Cuba and Venezuela), I argue that democracy is not dying. For better or worse, it is moving forward. Recent events do not necessarily mean that democracy is on the brink of extinction; rather, they show that there are challenges inherent to democratic life. If anything, the heated public debates confirm that democracy is a living process, which requires constant maintenance and strengthening.

Democracy cannot succeed by inertia. It is unreasonable to assume that the fight against authoritarianism is won because not one, but three waves of democratization have occurred or because the free world defeated totalitarianism in the $20^{\text {th }}$ century and created a robust international law regime to protect human rights. ${ }^{1}$ Democracy, freedom, and human rights, require never-ending democratic actions and behaviors from all sectors of society, domestic and international. Leaving democracy to proceed by inertia alone, and if its supporters are passive and silent, risks the total collapse of democratic norms and institutions as we have seen in Venezuela.

Regardless of the democratic deficits and emerging anti-rights agenda in recent years, democracy is the preferred form of government of the clear majority and a right for the peoples of the Americas. ${ }^{2}$ Except for the dictatorial outliers, the Hemisphere is home to young democracies that are going through growing pains. Granted, these growing pains are far more severe for some than for others.

There is no such thing as the perfect democracy, but it is important to act as though such a thing is possible. Democracy requires constant, continuous work. As such, the system relies upon the accumulation of small

The $10^{\text {th }}$ Secretary General of the Organization of American States, Minister Luis Almagro is a Uruguayan lawyer, diplomat, and politician. 
victories on the path of respect for and protection of democratic and human rights. Unfortunately, the Americas have not rid themselves entirely of authoritarian conditioned reflexes. The rest of the world has not either. This is partly due to human nature, both its humane and inhumane dimensions. The dark, anti-democratic and anti-rights side-as the persistence of dictators, extremely personalist forms of leadership, organized crime, terrorism, and corruption shows-is always alive and attempting to corrupt and co-opt those actors and causes that support human dignity, rights, and democracy development.

This includes international actors and causes. The threats to democracy, human rights, and human dignity do not respect borders; therefore, the role of the international community and diplomacy in championing and protecting human dignity is essential. Given the need for international checks and balances to ensure that the humane and civilized outweighs the corrupt and authoritarian, the Organization of American States (OAS) exists to assure that there is compliance with Inter-American and international law pertaining to democracy and human rights throughout the region.

\section{The Role of the OAS}

The OAS has acted to maintain and strengthen democracy and human rights in the Americas in accordance with its core values enshrined in InterAmerican law. There was a time when the OAS fulfilled this role on paper only, but not in reality. The Organization was not at the center of the political agenda of the Hemisphere. It was merely an instrument, a place, a platform, in which political interests and the dominating powers of the geopolitics of the day convened, bargained, negotiated, colluded, and/or exchanged views. It was a passive organization; an OAS that was not active, did not know its purpose, and was whatever its member states and its General Secretariat wanted it to do and be at any given time.
The OAS must be what the peoples of the Americas want it to be; it must be, and is today what the member states agreed by formal Inter-American agreements, an instrument to serve the American peoples. The OAS should always stand by these principles and values and should work for the peoples of the Americas, as a function of their needs and of principles, and not as a function of politics and individual interests.

The way forward should be and is, to guide every decision, every action, every day in the General Secretariat, by democratic and human rights values. These values are already part of international law, particularly a norm approved by OAS member states in 2001, the Inter-American Democratic Charter (IADC). This instrument resolves that the essential elements of representative democracy include:

respect for human rights and fundamental freedoms, access to and the exercise of power in accordance with the rule of law, the holding of periodic, free, and fair elections based on secret balloting and universal suffrage, the pluralistic system of political parties and organizations, and the separation of powers and independence of the branches of government. ${ }^{3}$

Article 4 also mentions that transparency in government activities, probity, responsible public administration on the part of governments, respect for social rights, and freedom of expression and of the press are essential components. ${ }^{4}$

The IADC represents the democratic ideals to which we aspire, to which we direct our efforts. In theory, democracies in the region should attempt and/or be as close to this ideal as possible. In practice, the story is different. Defending principles is often viewed as an unconventional way of doing diplomacy, but it should not be unconventional at all. Defending human rights, human dignity, and democracy should 


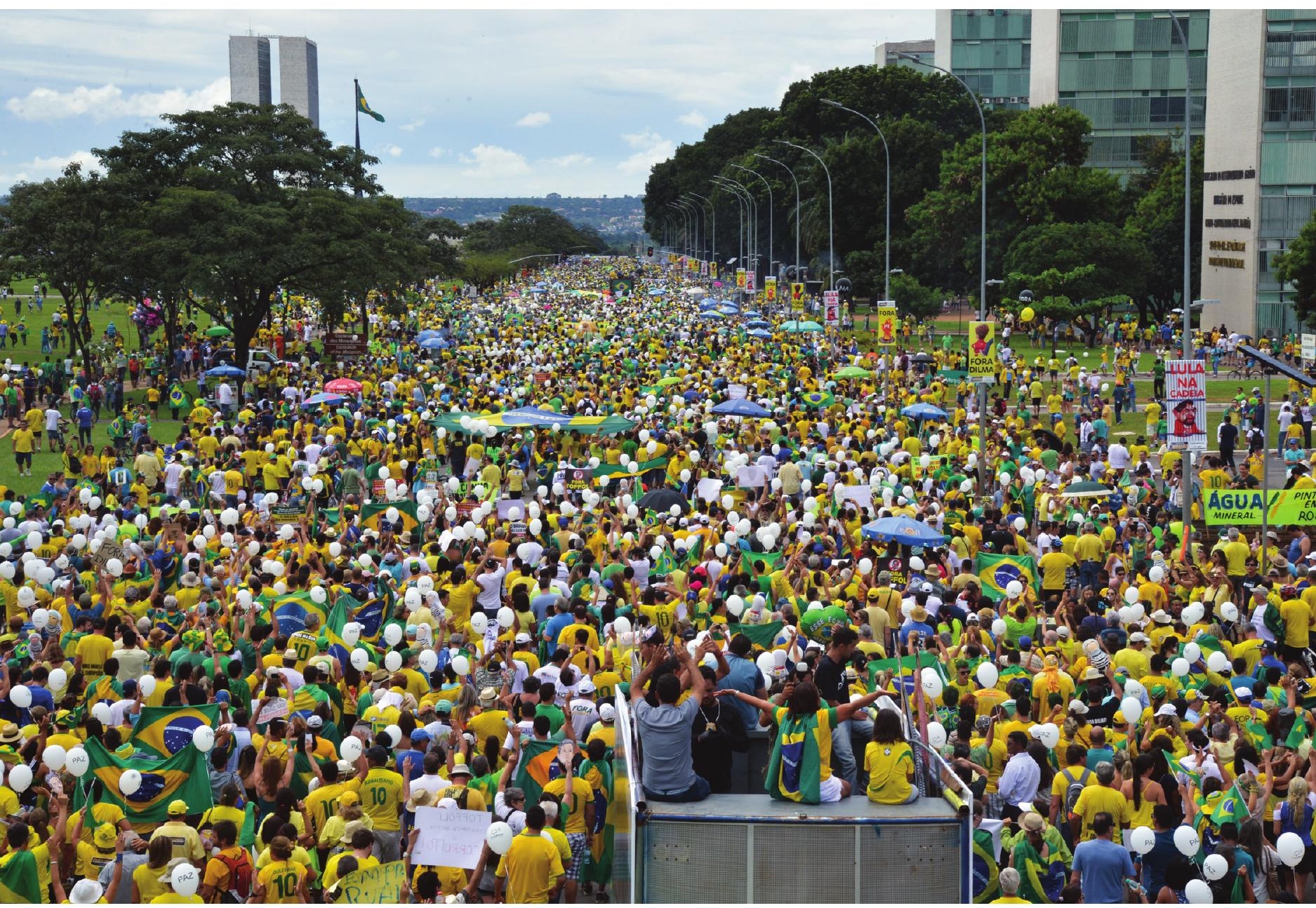

In mid-March 2016, protesters go to National Congress Palace denouncing corruption and calling for the departure of Brazilian President Dilma Rousseff. (Agência Brasil Fotografias)

be the normal and expected course of action. The international community, including the OAS General Secretariat and its member states, should strive to be consistent in theory and practice. The environment in which the OAS acts, and in which democracy develops, is challenging.

\section{Challenges to Democracy}

Today in the Americas there are high-levels of social and political tension both north and south, and between democracies and dictatorships. The Hemisphere is home to 35 states, all democracies except two dictatorships (Cuba and Venezuela), and one that is transitioning toward dictatorship (Nicaragua). These latter are governments that repress people through conventional means such as torture and political persecution, as well as through less conventional patterns of repression such as hunger and disease.

The voices of the victims of the abuses of these dictatorships speak by themselves of the challenges ahead to bring justice and strengthen democracy. As of November, there are hundreds of political prisoners in Cuba, Venezuela, and Nicaragua. 
There is evidence of torture. There is evidence of forced disappearances, and extra-judicial assassinations at the hands of the state that is supposed to protect them.

In 2014, Johanna Aguirre and her husband, Alejandro, were about to have dinner at their home, when Alejandro decided to join the nearby protests in Caracas, Venezuela. ${ }^{5} \mathrm{He}$ was filming the deployed Guardia Nacional Bolivariana on the street with his cell phone, and when he refused to surrender his phone, he was beaten and taken. He disappeared for hours and finally Johanna found him in a hospital bed, in a coma; he died days later. Alejandro died because he expressed dissent and protested, and because he had the "audacity" to film the repression. Now Johanna will spend her life fighting to get justice for him.

The testimony of Marco Novoa, a Nicaraguan protester whose forced disappearance and torture during the outbreak of the crisis for being the water coordinator - the person in charge of bringing water to the students who were in the barricades-is also disturbing. ${ }^{6}$ Marco said that the experience "took his humanity." His life changed completely since April 2018. He was to graduate last summer, start his life as a young adult, and perhaps get a job. Instead, he will now live forever with the horrific scars left by torture. And he will live seeking justice, for himself and for those who are still detained and tortured by regime forces in Nicaragua.

In October, two more dissidents were assassinated in the region. Oscar Herrera Blandon was shot by paramilitary forces in Nicaragua, and Fernando Albán was killed by the premier intelligence agency in Venezuela. Juan Requesens, a Venezuelan opposition leader, now a political prisoner, is subject to torture and has not been given appropriate medical attention. As of early January, the Venezuelan nongovernmental organization Foro Penal registered a total of 966 political prisoners in the country, representing a sharp uptick from the total of 232 in
November; in addition, 7,495 individuals are subject to judicial processes for political reasons. ${ }^{7}$

The testimonies of these victims and their relatives should force leaders to recognize fundamental truths. There is simply no access to human rights in too many places in our Hemisphere, there are no guarantees, and there is no due process that allows individuals to defend themselves. That is morally unacceptable, in addition to being illegal from the standpoint of international human rights law and the basics of the rule of law.

Comparing this situation to that in the rest of the world, there are two obvious negative aspects of the current quality of democracy in Latin America: it remains the most economically unequal region in the world, and it is also the most violent region on the planet. ${ }^{8}$ Organized crime, drug trafficking, violent death, lack of access to rights, poverty, and extreme poverty are persistent threats. The power of transnational organized crime is in some areas greater than that of the state. Shameless corruption, which has always existed, has come to the surface and angered citizens who now often blame democracy for its shortcomings. According to the latest Latinobarómetro survey of 18 Latin American countries, the proportion of people who are dissatisfied with democracy increased from 51 percent in 2009 to 71 percent in $2018 .^{9}$

However, according to the Freedom House scores, the standing of the Western Hemisphere vis-àvis the rest of the world is not that dismal. According to the Freedom in the World 2018 Report, the Americas is second only to Western Europe in terms of freedom and respect for human rights worldwide, despite democratic backsliding and an escalation of authoritarian tendencies, populism, and violence. ${ }^{10}$

If democracy in the Hemisphere today is compared to the past-to how it was in the 1970s and 1980s-the record is mixed. On the positive side, the most notable progress is that there were numerous successful transitions to democracy from 
dictatorships and authoritarian rule to electoral democracy. Great effort and political will has been invested in building democratic institutions, creating pluralistic political party systems, strengthening the judiciary and the rule of law, and liberalizing political systems to provide and protect more political rights and more civil liberties.

However, it has not been enough. The scores for political rights and civil rights assigned by the Freedom House methodology across two decades show a relative decline of freedom in the Americas. In 1998, 74 percent of the countries assessed were considered Free, 23 percent Partly Free, and 4 percent Not Free. ${ }^{11}$ By 2018, 66 percent of the 35 countries were categorized as Free, 28 percent as Partly Free, and 6 percent Not Free. ${ }^{12}$ In recent years the region lost a democracy, and by extension gained a new dictatorship. Venezuela joins Cuba in the "Not Free" ranks. Nicaragua could soon follow suit.

Comparing Latin America today to the 1970s and 1980s, reveals that quantitatively there were more authoritarian governments and dictatorships back then. Yet the two dictatorships that exist today, Cuba and Venezuela, have shown shrewd capacity for exporting bad practices throughout the region.

This is worrisome for many reasons, but I will highlight the three most relevant. First, the question of silence and appeasement from the rest of the region, at least initially. Bad practices exported and propagated systematically by dictatorships gained more and more strength as there was increasing fear and silence from democratic and human rights voices in the region to denounce them in formal, multilateral, political forums. After the transitions to democratic rule across the region, there were not supposed to be more dictatorships, which were considered artifacts of the past. During the transitions it was believed by many that democracy was now firmly established as the only game in town. But one dictatorship did survive the turn of the centuryCuba-and another emerged in Venezuela. Formal denunciations have been made in the international sphere, specifically since the resolutions approved by the OAS Permanent Council in April 2017. ${ }^{13}$

Second, the nature and impulse behind the toxic effects of the Cuban and Venezuelan regimes on the rest of the region do not derive from ideology as in the past century. They oppress and repress not because of an ideology or national security doctrine that defines enemies of the state framed within Cold War politics. Cuba and Venezuela repress any individual who represents a threat to regime permanence in power. They export practices such as polarization, violent repression of innocent civilians, rampant corruption, and criminal activities. Their strategy to instill fear as a way of governing has nothing to do with ideology, and everything to do with personal gain.

And third, the persistence of these dictatorships is worrisome given that we are dealing in our very Hemisphere with regimes that operate shamelessly within a different values system entirely, incompatible with morally and legally accepted human rights and democracy principles in international relations. This trend is similar to the behavior of global authoritarian players elsewhere in the world that are blatantly ignoring the human rights and principles agenda.

Regardless of the technological advances and the rise of social media that make events evident and in real time to the public, these regimes overtly kill, repress, and oppress their own people, but blatantly and shamelessly deny it.

\section{How to Respond to Challenges}

Democracy is not dying, but action is needed to achieve justice and keep moving democracy forward. There is a need to permanently address countries' bad practices and encourage them to adopt good practices. Common bad practices in political systems in the region are; co-optation of the judiciary, blocking the action of parliaments and/or members of parliament, the threat of or assassination of political 
candidates, corruption, impunity, murder of human rights and environmental activists, and blocking political participation, among others.

The good news is that the OAS is responding to that in cooperation with civil society. The time when those guilty of corruption enjoyed impunity is over. Impunity is being pushed back, the corruptors shamed, and the possibility of justice is becoming a reality. The work of the Mission to Support the Fight against Corruption and Impunity in Honduras (MACCIH, for its initials in Spanish), since it was established in 2016 is a case in point. The certainty of justice in the Americas is the ideal, but it will still take a while to achieve.

As the previously mentioned cases of Cuba, Venezuela, and Nicaragua show, the challenges ahead are not only how to tackle the deficits in democratic governance, but also the persistence of dictatorships. It is not simply a problem of governments not having the capacity, in terms of human resources, budget, and management, to respond to pressing issues such as drug trafficking and gang violence. The challenge is not only to fight rampant corruption and impunity within the framework of imperfect democratic states. The main test now is to fight those who are deliberately eliminating the basic human rights of their own people, within their borders.

Venezuela is the greatest, most painful test of the commitment to democracy of OAS member states. How should the international community respond to this test? Venezuela is not only a failed state, it is a free-falling narco-state. The regime is led by individuals who have been charged with corruption and drug trafficking. They know that if they leave their positions of power, they will face justice.

The Venezuelan regime has destroyed checks and balances and governmental institutions, destroyed free and fair elections, destroyed the economy, destroyed PDVSA (the Venezuelan national oil company), destroyed democracy while it steals millions, and has persecuted, imprisoned, tortured, and killed its "internal enemies": innocent civilians who simply do not support and agree with the regime. They have even deliberately starved infants and

Figure 1: OAS Member State Votes on Venezuela 2016-18.

25

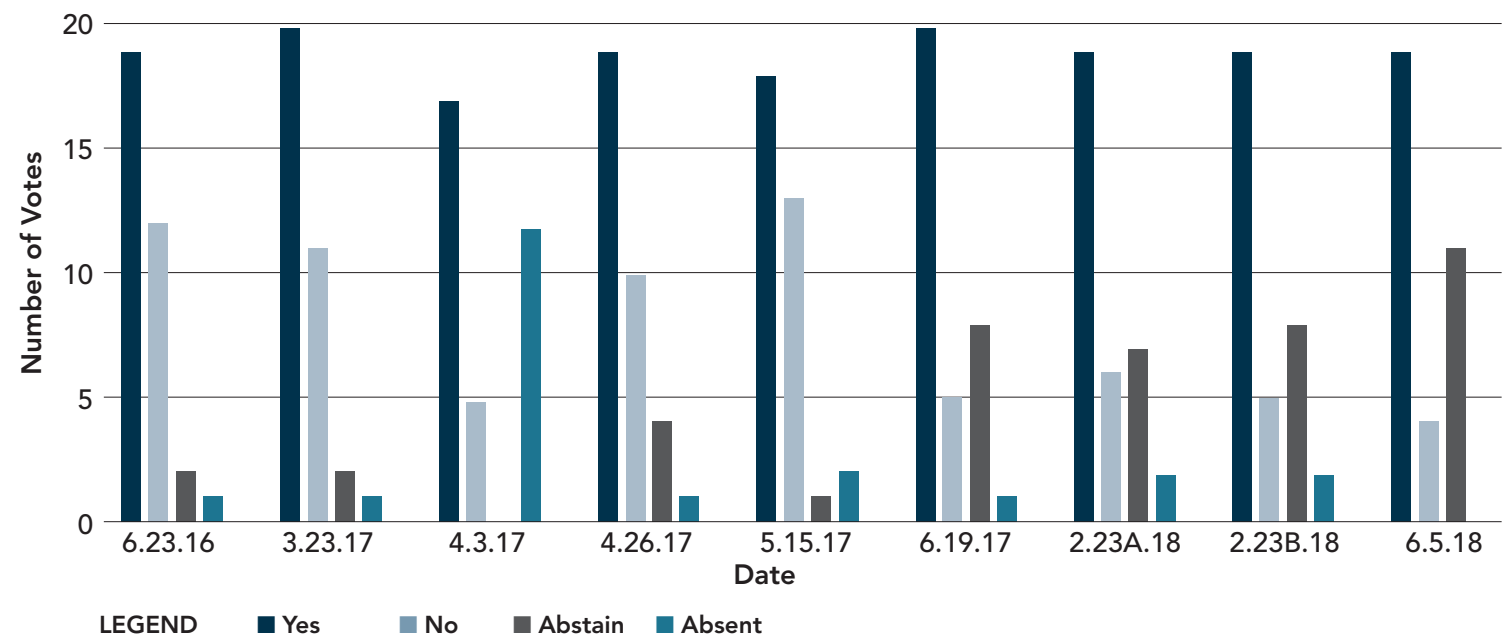

Source: Derived from votes recorded during sessions of the Permanent Council, Meetings of Consultation of Ministers of Foreign Affairs, and OAS General Assemblies from 2016-18. 
reduced hospitals to penury, without running water; and surgeries if done at all, are performed by candle light or the flashlights of cell phones. ${ }^{14}$

This crisis is also far from a trivial discussion of leftist and rightist politics. The current situation is about human tragedies, and about a regime that has intentionally and systematically crushed the human dignity of its people. The suffering of Venezuelans is evident not only in Venezuela. The dictatorship has caused the largest migratory exodus in the history of our Hemisphere: 3.3 million Venezuelan refugees have fled the oppression and repression of the Maduro regime; and 1.8 million more are expected to leave by year-end. Countries in the region are trying to absorb the refugees and migrants, many who arrive by foot, but it has proven a difficult economic, social, and cultural challenge. Colombia President Iván Duque Márquez recently mentioned that migrant influx costs 0.5 percent of the country's GDP.

Since 2015 the General Secretariat of the OAS has observed the situation, documented facts and testimonies, and acted accordingly. The Secretariat was the first in the region to call the problem by its name-a dictatorship. So far, four published OAS reports documented evidence of the escalation of the crisis, as well as justification that there is an unconstitutional interruption of democratic order as defined in Chapter IV of the IADC. ${ }^{15}$

The principles that are already in our international instruments and international law must be put into action. There has been progress. So far two resolutions have declared illegitimate the alteration of the Constitutional Order as well as the elections in May. ${ }^{16}$ This is a clear indication that some member states are acting morally and according to international law by actively fighting a dictatorship rather than remaining on the sidelines for whatever national or particular reason, as many have done and many still do.

The voting pattern of the OAS member states on issues related to Venezuela in 2016-19 sheds some light on where states stand vis-à-vis the moral dilemma. Figure 1 shows that while the number of countries voting against the interests of the Venezuelan dictatorship has remained constant, the number of member states voting in favor has decreased, and in lieu, the number of abstentions has increased substantially. ${ }^{17}$

Only tangible action-such as such votes against the dictatorship-gets Venezuela closer to justice and returning democracy to the country, and by extension, increasing the state of democracy in Latin America. It is quite hard to accept that there are crimes against humanity being committed in Latin America again. But it is a reality that cannot be denied. On the contrary, it is imperative to work to find justice for the victims. There is no other way.

\section{The Moral Dilemma}

The Venezuelan crisis transcends politics. It is a test of the power of principles, of where the Inter-American community of nations and its leaders stand when facing a moral dilemma: is the Hemisphere pro-democracy or anti-democracy? There are two paths ahead: action according to universal human principles of tolerance and respect, seeking the greater common good even if it means personal sacrifices; or inaction and maintenance of the status quo, preferring to succumb to indifference and silence even though it means that this inaction is indirectly killing and repressing innocent people.

This OAS General Secretariat administration unconditionally chose the first option. In July 2017, immediately after the General Assembly of Cancun, the OAS decided to push forward solutions for human rights abuses as well as crimes against humanity. In September 2017, the OAS Panel of International Independent Experts was created, documenting denunciations, testimonies, cases, and facts. In May, the Panel published a report that concluded there were reasonable grounds to believe that crimes against humanity were committed by the Venezuelan regime. ${ }^{18}$ 
On September 26, countries of the Americas made history - for the first time a country or group of states referred a case involving crimes against humanity in another state to the International Criminal Court (ICC). Argentina, Canada, Chile, Colombia, Paraguay, and Peru in their referral referenced the report of the OAS, and France, Costa Rica, and Germany joined the group afterward. The referral symbolized the effective use of international law to bring justice for the victims of the dictatorship. The OAS will continue on this path of justice, human rights, and democracy. It will continue to exert pressure, no matter the cost. This is the new form of war the Hemisphere faces against old enemies-democracy versus tyranny.

The responsibility of the international community and diplomacy is to defend people, not states. Action based on principles is the only way forward for responsible diplomacy. The best partners for those who violate human rights and commit crimes against humanity are those who remain silent and inactive. Venezuela is a warning sign to the rest of the region and the world that, no matter how rich in natural resources you are, no matter if you had enjoyed a sort of democratic stability when everybody else was submerged in dictatorial rule, democracy cannot be taken for granted.

There is one certainty in all of this: if there is to be a better quality of democracy in Latin America, if justice is to be done for the victims, if the international community wants to avoid having more victims like Marco, Oscar, Fernando, Juan, and so many others, then action and work must follow a legal and moral doctrine that is already agreed in international law, to protect the people, and not necessarily the states.

\section{Democracy, Never-ending}

In sum, democracy is an ongoing quest; the multidimensional criteria by which we analyze a democracy are clearly laid out in the Democratic Charter and other Inter-American norms. Democracy is a right of the peoples of the Americas. The OAS is doing its part to ensure that all peoples in the Hemisphere maintain and can exercise this fundamental right. The OAS will continue to support member stateseach with its own different degree of democracy and democratic ailments-in their never-ending quest for political, civic, economic, and social liberties. The OAS stands firm in its commitment to the values and principles of human rights and democracy, and to the shared future goal of achieving and maintaining 35 free and democratic member states in the Hemisphere.

The competition between democratic and anti-democratic forces is playing out in the Americas. Democracy will not repair its shortcomings by itself. Therefore, the Inter-American community, and the international community as a whole, must propel us toward democratic improvement, if the goal is more and better democracies, freer societies, and ultimately more rights for more people. The power of principles and a transnational moral responsibility, consistent with international law, should be the doctrine implemented to defend people, not to defend states. PRISM

\section{Notes}

${ }^{1}$ According to Samuel P. Huntington, the first wave of democratization took place in the $19^{\text {th }}$ century, followed by a second wave after World War II. Huntington described the democratization of more than 60 countries throughout the world following the 1974 "Carnation Revolution" in Portugal as the "third wave" of democratization. See: Samuel P. Huntington, The Third Wave: Democratization in the Late Twentieth Century (University of Oklahoma Press, 1991).

${ }^{2}$ OAS, "Inter American Democratic Charter, Chapter I Democracy and the Inter-American System," Lima, Peru, September 11, 2001, available at <http://www. oas.org/charter/docs/resolution1_en_p4.htm>.

${ }^{3}$ Ibid.

${ }^{4}$ Ibid.

${ }^{5}$ Testimony of Johanna Aguirre at the Hearing of the OAS General Secretariat to analyze the possible commission of crimes against humanity in Venezuela, 
September 14, 2017, available at <https://www.youtube. com/watch?v=KRX0QaJPzRk $>$.

${ }^{6}$ Joshua Partlow, “They Took my Humanity':

Pro-Government Paramilitaries Terrorize Nicaraguan Protesters," Washington Post, August 2, 2018, available at $<$ https:/www.washingtonpost.com/world/the_americas/ they-took-my-humanity-pro-government-paramilitaries-terrorize-nicaraguan-protesters/2018/08/02/349f8 914-900a-11e8-ae59-01880eac5f1d_story.html?noredirect=on\&utm_term $=. e 23011 \mathrm{~d} 1 \mathrm{ba11}>$

${ }^{7}$ Foro Penal Venezolano, Twitter post, 2018, available at <https://twitter.com/alfredoromero/status.1059529448788254721>and <https://twitter.com/ alfredaromero/status/109242743124217858>.

${ }^{8} 42$ of the 50 most violent cities in the world are in Latin America. See Christopher Woody, “These were the 50 most violent cities in the world in 2017," Business Insider, March 6, 2018, available at <https://www.businessinsider.com/most-violent-cities-in-the-world-2018-3>.

${ }^{9}$ Latinobarómetro, "Informe Latinobarométro Survey 2018," (Santiago, Chile: Corporación Latinobarómetro, 2018) available at <http://www.latinobarometro.org/lat.jsp $>$.

${ }^{10}$ Freedom House, "Freedom in the World 2018," available at <https://freedomhouse.org/report/ freedom-world/freedom-world-2018>.

${ }^{11}$ Freedom House, "Freedom in the World 1998," available at <https://freedomhouse.org/report/ freedom-world/freedom-world-1998>.

${ }^{12}$ Freedom House, "Freedom in the World 2018."

${ }^{13}$ OAS Permanent Council, Resolution 1078, Recent Events in Venezuela, E-022/17 (April 3, 2017), available at $<$ http://www.oas.org/en/media_center/ press_release.asp?sCodigo=E-022/17>; and OAS General Assembly, Resolution 2929, Regarding the Situation in Venezuela, D-032/18 (June 5, 2018), available at <http:// www.oas.org/es/centro_noticias/comunicado_prensa. asp?sCodigo $=\mathrm{D}-032 / 18>$.

14 "Collapse of the Venezuelan Health System,"The Lancet, vol 391, April 7, 2018, available at <https:// www.thelancet.com/pdfs/journals/lancet/PIIS01406736(16)00277-4.pdf>.

${ }^{15}$ The release dates and links for the four OAS reports are: OAS, "Reports on Venezuela: I,” May 30, 2016, available at <http://www.oas.org/documents/spa/ press/OSG-243.es.pdf>: "II," March 14, 2017, available at <http:/www.oas.org/documents/spa/press/Informe-VZSpanish-signed-final.pdf; "III," July 19, 2017, available at <http://www.oas.org/documents/spa/press/TERCERINFORME-VENEZUELA-SPANISH-Final-signed.pdf >; "IV," September 25, 2017, available at <http://scm.oas.org/ pdfs/2017/CP38157INFORME.pdf >.
${ }^{16}$ Res 1078 of April 2017; and Res 2929 of June 2018.

${ }^{17}$ Special Session of the Permanent Council June 23, 2016; Special Session of the Permanent Council March 28, 2017; Special Session of the Permanent Council April 3, 2017; Special Session of the Permanent Council Resolution April 26, 2017; Special Session of the Permanent Council Sets Date for Meeting of Consultation of Ministers of Foreign Affairs May 15, 2017; Meeting of Consultation of Ministers of Foreign Affairs during the General Assembly June 19, 2017; Special Session of the Permanent Council February 23, 2018; General Assembly June 5, 2018; and Special Session of the Permanent Council January 10, 2019.

${ }^{18}$ OAS, Report of the Organization of American States and the Panel of Independent International Experts on the Possible Commission of Crimes Against Humanity in Venezuela, (Washington D.C.: OAS General Secretariat, May 29, 2018), available at <http://www.oas. org/documents/eng/press/Informe-Panel-IndependienteVenezuela-EN.pdf $>$.

\section{Photos}

Page 2. Wikimedia/Name withheld on request of copyright owner. Licensed under Creative Commons Attribution-ShareAlike 3.0 Unported License. Photo produced unaltered.

Page 5. Licensed under Creative Commons Attribution 2.0 Generic License. Photo unaltered. 


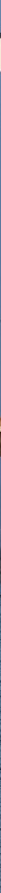

Juscelino Kubitschek bridge in Brasilia, Brazil; Latin America is no longer a development backwater. (Wikimedia/Erik Gaba) 


\title{
The Strategic Price of Neglect
}

\author{
By Peter Schechter
}

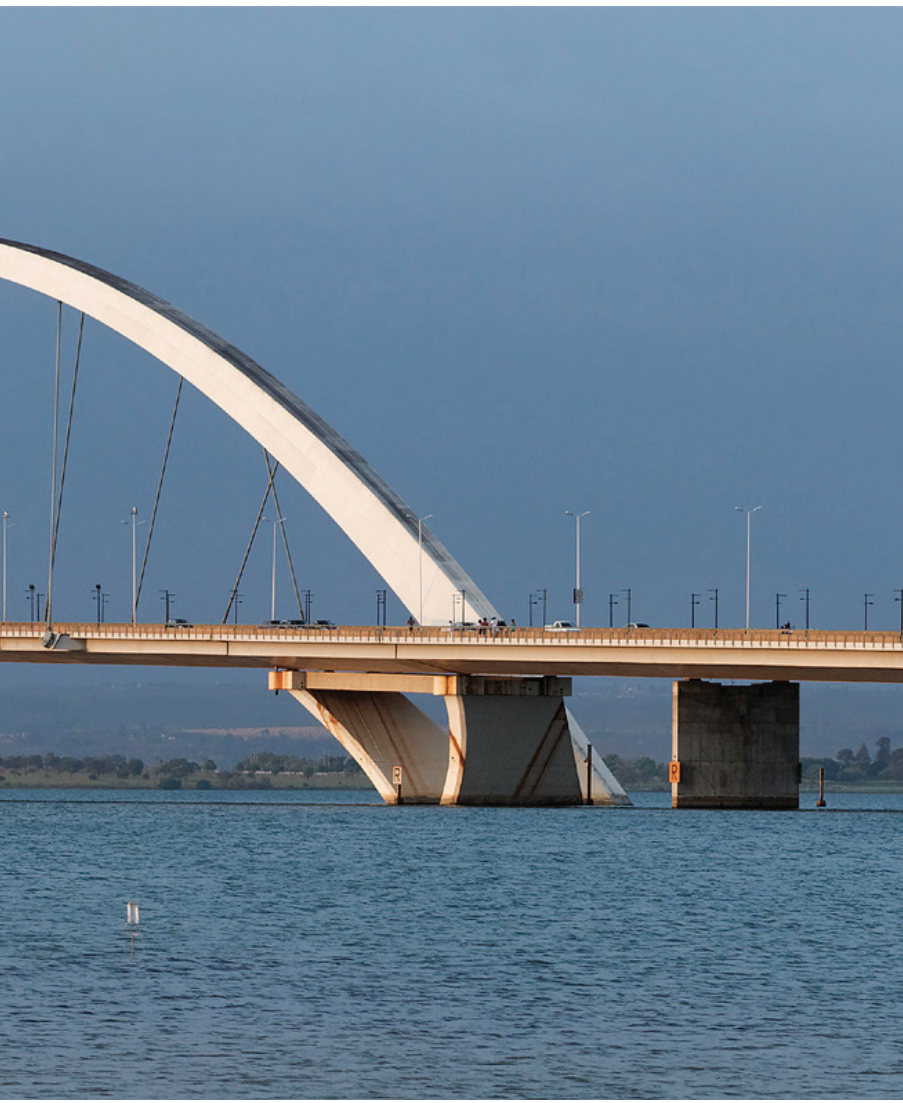

$\tau$ atinoamericanistas - those of us who follow, love, and have dedicated much professional and personal attention to Latin America-are often quick to complain about the historical U.S. neglect of "our" region. On the campaign stump, then Governor George W. Bush hinted at the long periods of negligence when he said, "Should I become president, I will look south, not as an afterthought, but as a fundamental commitment of my presidency."

Indeed, we who advocate for stronger regional ties have long been disappointed with the lack of attention from U.S. policymakers. We have pointed to the dearth of commercial favoritism from America's businesses. We have argued for more assistance, more presidential visits, more creative policy frameworks.

But this time, something is very different. The United States is at a historic juncture. It cannot afford the costs of continued neglect towards the region because today the United States is incurring more than just lost opportunity costs. Uncertainty is everywhere; it is even more acute beyond Latin America. It tears at the fabric of America's alliances and puts into play the 70-year old, U.S.-created post-war international order. Decades-old friendships are now in question.

Mr. Peter Schechter is co-host and executive producer of the global issues podcast, Altamar. An entrepreneur, strategist, and foreign policy expert, Mr. Schechter is also the former founding director of the Atlantic Council's Adrienne Arsht Center on Latin America. 
Like other U.S. allies, the region is confused by the conflicting signals from the United States. On the one hand, Latin music, culture, food and drinks are skyrocketing in popularity. ${ }^{2}$ The U.S.-based investments of multilatinas, Latin multinational companies, are prospering and U.S. foreign direct investment in the region is growing. ${ }^{3}$ On the other hand, except for Venezuela, the United States government's policy toward the hemisphere has, during the past eighteen months, oscillated between apathy and disdain. Reference to Latin America is often accompanied by an unusually sharp barrage of criticism of Latin Americans in general and Mexicans in particular. Tariffs have targeted some of the region's important exports. And, President Trump passed on the chance to meet his regional colleagues at the Summit of the Americas.

This detachment is unfortunate. In the past 25 years, the region has changed radically-mostly for the better (although, in a few cases, for the dismally worse). More importantly, while the world recognizes the transformation of the region, the United States cannot seem to let go of its view of Latin America solely through the narrow lens of drugs, crime, and immigration.

Indeed, Latin America is a good mirror of our times; an apt measurement of the zeitgeist of doubt. Having cemented its democracies and reformed its economies, some of America's closest Latin American friends are reassessing their options and realigning their interests away from the United States. Our closest regional friends are realizing that the United States may no longer be the fulcrum of Latin America's future. While America's soft power-its culture, innovation, and ethos-are still highly attractive, the fact is Europe, Asia, and China are capturing much of the region's political imagination and economic attention.

At a time of fast change, it is hard to think strategically. Yet, strategy is what will be needed to re-prioritize Latin America within U.S. foreign policy. At some point-in this administration or the next - there will inevitably be a debate about the role of China in Latin America. In her report this year on Chinese engagement with Latin America, the InterAmerican Dialogue's Margaret Meyers asks whether China has understood the appeal to Latin American governments of inclusive rhetoric and development-oriented policies-maybe better than the United States. ${ }^{4}$ Today, there is a price for neglecting the region: the abdication of influence to the United States' most important strategic rival.

\section{If You Were Latin American, China Would Look Pretty Good}

China's fast-growing interest in the region, in fact, has not gone unnoticed by U.S. policymakers. In February 2018, former U.S. Secretary of State Rex Tillerson warned Latin American countries against excessive reliance on economic ties with China, arguing that the region did not need new imperial powers: "Today China is getting a foothold in Latin America. It is using economic statecraft to pull the region into its orbit; the question is at what price?"5

Secretary Tillerson was not wrong. The United States should be worried about its waning influence with an estimated 640 million increasingly middle-class Latin Americans. Yet, notwithstanding the apparent preoccupation, U.S. actions in the region seem designed to distance the United States from its regional neighbors. Compare China's "peaceful rise" of investments and trade missions or Europe's negotiation of a Mercosur-EU trade deal with the demarche from the Trans-Pacific Partnership, assaults against NAFTA, the North American Free Trade Agreement (which now has turned into the United States-MexicoCanada Agreement), rhetorical attacks on Mexico, tariffs on Argentina and Brazil, and the harsh treatment of Latin American migrants, including the tear gassing of Central Americans at the Tijuana border. ${ }^{6}$

As an example, the Economist's Bello column juxtaposes the Trump Administration's rhetoric 
during the World Economic Forum in Davos, Switzerland early last year with Chinese Foreign Minister Wang Yi's speech during the same period while attending the China and the Confederation of Latin American and Caribbean States (CELAC) to promote globalization, free trade, and co-operation with Latin America. China, in the soothing words of Minister Wang, offers Latin America a "strategy of mutual benefit and shared gain."7 In fact, since that speech Minister Wang, as of mid-2018, has completed at least 14 ministerial-level meetings with government officials from the region, discussing trade, bilateralism, surely all while selling the 'intuitiveness' of including Latin America in the One Belt One Road (OBOR) initiative in coming years. ${ }^{8}$

The difference with the United States is not just stylistic; it is substantive. Talk to Latin American leaders and you will hear a consistent theme: the Chinese are willing to provide trade, financial assistance, and technical help. They construct the infrastructure, invest in local companies and grow commerce. Chile's former Foreign Minister, Heraldo Muñoz, summed up these feelings during the China-CELAC summit in Santiago in January 2018- "We are in uncertain and complex times, and China is playing a very constructive role in addressing these complexities."

It is worth reviewing some of the salient facts of Chinese influence in the region. In the past five years, total annual trade between China and Latin America shot up from almost nothing to more than $\$ 200$ billion by 2014. After stalling for the next two years, Latin America's exports to China increased by around 30 percent in 2017, according to the InterAmerican Development Bank (IDB), mainly because of an increase in the price of South American oil, minerals and other commodities. China is the largest trading partner of Brazil, Chile, and Peru. ${ }^{10}$

It is not just trade. Chinese investment in the region, according to a report by the Boston University's Global Development Policy Center, has continued to rise. In just the past couple of years, Chinese companies have increased their new "greenfield" foreign direct investment in the region from $\$ 2.7-\$ 4.3$ billion during 2016-17, totaling to $\$ 29.5$ billion from $2013-17 .{ }^{11}$ Since 2008 , the region has become the second largest destination for Chinese finance. ${ }^{12}$ Chinese investors are diversifying away from extractive industries and, smartly, from a geographic focus on Venezuela. Investments in Brazil and Argentina have recently shot up, concentrating on banking and infrastructure projects such as railroads, power plants, and ports. ${ }^{13}$

Importantly, there has been some understandable preoccupation about the impact of Chinese trade on Latin economies. Reports by the Atlantic Council and others have expressed concern that Chinese demand for raw materials exacerbates the dependency on low-end exports and has a deindustrializing effect on the region's heavy industries such as steel, plastics, and glass. ${ }^{14}$ Recent meetings with officials and think tanks in China have convinced me that the Chinese are aware of this criticism and are seeking to compensate through increased investments.

China's currency, the renminbi, now has regional clearinghouses in Latin America to facilitate trade. In 2015, the People's Republic of China opened two of these Offshore Clearing Banks in Latin America, first in Santiago, Chile, and then in Buenos Aires, Argentina. ${ }^{15}$ These clearinghouses facilitate trade integration between China and the clearinghouse's host nation by allowing direct dealing in either currency, lowering transaction costs, and streamlining administrative obstacles. ${ }^{16}$ Though the renminbi still trails other global currencies, it has transcended its humble beginnings in the past 15 years or so. According to the UN Economic Commission for Latin America and the Caribbean (ECLAC), the International Monetary Fund accorded special drawing rights to the renminbi, granting it potential to be used for IMF loans. Not to mention that the renminbi has become an increasingly desired currency on 
global financial markets, with at least 60 countries possessing a cache of the Chinese currency. ${ }^{17}$

Notwithstanding some very public setbacksespecially in Sri Lanka and Malaysia-China has caught the world's attention with its Asian Infrastructure Investment Bank (AIIB) and the OBOR initiative. While both are mostly designed for Asia, Panama surprised many by being the first Latin America nation to petition joining the Belt and Road initiative. Even Chile's conservative new president, Sebastian Piñera, used his campaign stump speeches to promote the importance of a deeper bilateral relationship between China and Chile. Chinese capital flows have grown exponentially.

There has been considerable recent commentary that China's Belt and Road Initiative is little more than a 'debt trap'. But the numbers speak for themselves. The ECLAC report from January 2018 on "Exploring New Forms of Cooperation between China and Latin America and the Caribbean," notes that 80 percent of international loans to Latin American nations from 2005-16 originated from the China Development Bank, totaling $\$ 141$ billion. " ${ }^{18}$ "Chinese lending to the region's governments exceeds that of the World Bank, the Inter-American Development Bank, and the CAF-Development Bank of Latin America." ${ }^{\text {19 }}$

Yes, there are some preoccupying Chinese military sales to a few governments in the region, including some radars and fighter jets to Venezuela, a national emergency response system to Ecuador, military trucks and buses to Bolivia and Peru. But make no mistake-America's leadership in the region is not threatened by China's military sales; it is being sapped by the trade and investment opportunities created by China's strategic approach to Latin America. ${ }^{20}$

When asked what the United States should do to combat China's growing influence in the region, a Brazilian official recently answered in exasperation: "Anything! Because now the U.S. is doing nothing." The truth is that slowing China's growing importance in Latin America will not be easy; it will require a proactive, positive and economics-oriented approach. America's lack of response is the longterm threat. Put bluntly, it is the chronic reluctance to fortify hemispheric relations against the flood of Chinese finance and diplomacy that may be the reason Washington is washing out of the region. Again, this is the key, costly price of negligence.

There is no question that today's increasingly middle class, western, and democratic Latin America is a key asset to sustaining a strong U.S. economy and spreading democratic values around the globe. What is far from clear, however, is whether the United States wants to put in the effort to regain its influence in the region.

\section{It is Not Your Grandmother's Latin America}

It is hard to overstate the profound changes in Latin America during the past twenty years, which have largely seen the hemisphere evolve into a more prosperous region with an admirable new political consensus. With some notable exceptions, change is all over and it is mostly positive. In a region that has seen its share of international conflicts, there are now no border disputes at risk of flaring into 
military conflict. Known in the past for blaming economic failures on outsiders, most Latin American nations have reformed their economies, sanitized their finances and raised millions out of poverty into a new middle class. Guerrillas and internal conflicts officially became a thing of the past with the recent signing of Colombia's peace agreement. Even the political turbulence caused by corruption investigations in Brazil, Peru, Colombia, and other countries means that the region's judicial institutions are becoming stronger and civil society's demand for transparency cannot be held back.

Perhaps the biggest change of all has been that, after a long history of inward looking, autarchic economic policies, much of Latin America now espouses a globalist mantra. Notwithstanding the rhetoric, politicians of vastly different persuasionsfrom Mauricio Macri in Argentina, Andrés Manuel López Obrador (known as AMLO) in Mexico to Jair Bolsonaro in Brazil-today want their countries to become stronger international competitors. Latin Americans largely favor politicians and policies that insert their economies into the global marketplace. Eleven countries in Latin America have free trade agreements (FTA) with the United States. ${ }^{21}$ Outside the neighborhood, Latin American nations have ratified or are negotiating free trade agreements with Japan, the European Union, Israel, and China.

As proof of its growing weight, three Latin American countries are now part of the Organization of Economic Cooperation and Development (OECD), with important cooperation programs and access discussions in the wings with Costa Rica, Brazil, Peru, and Argentina. The OECD is known as a club of wealthy, democratic countries-though it should be better branded, in Daniel Runde's words, as "a club for serious countries." 2 Colombia joined in 2018, following Mexico and Chile, as the $36^{\text {th }}$ member of the organization.

Even after years of economic slowdown and notwithstanding dire predictions, the 2018 "monster" year of elections in Brazil, Mexico, and Colombia brought to power a wide political spectrum, but has not altered a growing consensus towards open markets. In June, Iván Duque Márquez won in Colombia 54 percent to 42 percent against Gustavo Petro, a former guerrilla and leftist candidate. In the past 25 years, Colombia has earned recognition as consistently centrist. Petro's mere presence in the second round was groundbreaking. But in the end, Colombia's proclivity for caution won out.

In July, Mexico elected AMLO with more than 53 percent of the vote, a huge victory by Mexican standards. AMLO took office in December and he will hew a political high-wire act that combines accelerated social expenditures to the poor with protecting Mexico's hard-earned reputation as a manufacturing power. Despite fears that AMLO will reverse most of the previous government's important decisions (and he did, indeed, reverse the decision to construct a new airport in Mexico City), nothing he said in the campaign put Mexico's 2014 energy reforms or its outward looking, export-oriented manufacturing economic model into doubt

Bolsonaro, Brazil's newly elected populist leader, took office in January on a platform to battle rampant corruption and crime as well as promising to reignite Brazil's economy. Brazil has suffered one of the deepest and longest economic recessions in its history. There are legitimate worries that Bolsonaro's anti-crime crackdown could go too far. But, the election cemented a growing consensus that Brazil needs strong action to modernize its economy and engage further-not less-in the world. To that end, Finance Minister Paulo Guedes has promised to launch a deep program of privatization and reform.

With some glaring exceptions-led by Venezuela, Cuba, Central America’s Northern Triangle and, more recently, Nicaragua-Latin America has become a solid western bastion of 640 
million people. The region's countries are avid consumers of social media; indeed, Brazil is the world's second largest Facebook community. Democratic freedoms - the freedom to read anything, espouse a point of view and assemble to defend a cause - are not in question in most Latin countries. There are more women in the Congresses of Mexico and Argentina than in the U.S. Congress. Not withstanding Bolsonaro's rhetoric, gay marriage is legal in Brazil, Argentina, Uruguay, and Colombia.

Given Latin America's progress during the past two decades, this is the historical moment in which the United States and a rejuvenated Latin America should be most aligned. Even the much feared 'pink tide' of Hugo Chavez' Venezuela, and Evo Morales' Bolivia has failed completely; nobody in Latin America sees the catastrophe that Venezuela is today as a model for the future.

Indeed, many of the political and economic issues that divided the United States and the region in the past seem to have faded into history. From economic reforms, central bank independence, judicial strengthening, protections for journalists, liberating civil society and NGO's from government oversight, to the belief that open, global economies are the keys to prosperity-the United States and Latin America seem to finally be in synch across a spectrum of issues. Common economic, social, and political purpose has allowed greater cooperation on narcotics, immigration, and terrorism to occur without the historical sensitivities about hegemony and national sovereignty.

Sadly, that alignment has not happened. In 2016, America decided to move in a different direction, pivoting suddenly against the rules based international framework it had been preaching to the region for the past 20 years. Beginning with the administration's decision to pull out of the TransPacific Partnership, the break with the region is accelerating. The consequences of this shift will inevitably be felt in the decades to come.

\section{The "Arc of Confidence"}

It seems almost quaint to suggest-in this moment of international dislocation and uncertainty about America's leadership and the cohesion of the Westthe need for a "strategy" towards the region. Yet, this is exactly the right time to begin a debate about how to best integrate Latin America back into the U.S. foreign policy picture. At some point in the future, this administration or a future president will have to discuss whether U.S. policy now needs the creation of additional, new cornerstones.

When we do come to this debate, China will be its fulcrum. Its staggering 25 -year sprint to prosperity has astounded many and created admirers around the globe. At its core, China's success raises deep questions. Many of us believed - and preached-that democracy was the essential precursor element needed to create the combustion of prosperity. China has proven us wrong.

Yet, China's development-and the model it proposes to other countries-is profoundly different from America's. China's deep economic advances beyond Asia and Africa into Latin America will soon force us into a debate about a defense of common values. A discussion of values may sound haggard and harried today, but the United States, Japan, Korea, and countries across Europe and Latin America still comprise an "arc of confidence" of western-oriented, democratic nations that have chosen openness and inclusion.

Latin America is where the fight to expand the arc of confidence must succeed. Of the regions that share a commonality of values, Latin America is the youngest and largest. Seemingly the economic caboose, the region's growth potential makes it a possible locomotive for the preservation of democratic values. Admiral James Stavridis, former Commander, U.S. Southern Command writes,

The countries of Latin America and the Caribbean have large populations with 
strong cultural and religious linkages to the United States, are almost all democratic, enjoy vast natural resources, and represent the only region of the world that avoided a war in the $20^{\text {th }}$ century and are at peace today... we are lucky to be part of the Americas with partners like these. ${ }^{23}$

Including Latin America in an arc of confidence will require a whole new, positive policy that joins together democratic nations everywhere. But, in the Western Hemisphere, we will need to create new initiatives to promote growth, reduce inequality, enhance civil society and strengthen the values of democracy, freedom, and personal responsibility. This is not about crowding China-or anybody else-out of the region. It is about re-engaging with the hemisphere on an exciting, goal-oriented mission to re-imagine the hemispheric partnership and re-connect with Latin America on shared values and ideals.
The goal must be to take the impressive economic gains of the past two decades and push forward harder and faster-we must help to convert the majority of Latin America to become high-income countries by 2035 . The most important countries of the region have come this far; there is no reason that Latin American nations cannot break the mold and become more developed countries. Latin America is not condemned to underdevelopment. After all, Colombia, Mexico, Argentina, Peru, Brazil, and Chile stand today about where Spain and Portugal stood only 25 years ago.

The ability to reach high income status will require combining specific national level policies and reforms with strategically delivered U.S. partnership. Leaders across the region must adopt a shared vision of the path forward and their objectives. Governments must act in concert; with business and civil society stakeholders included in the effort.

This effort will require large, highlydirected investments in infrastructure, education,

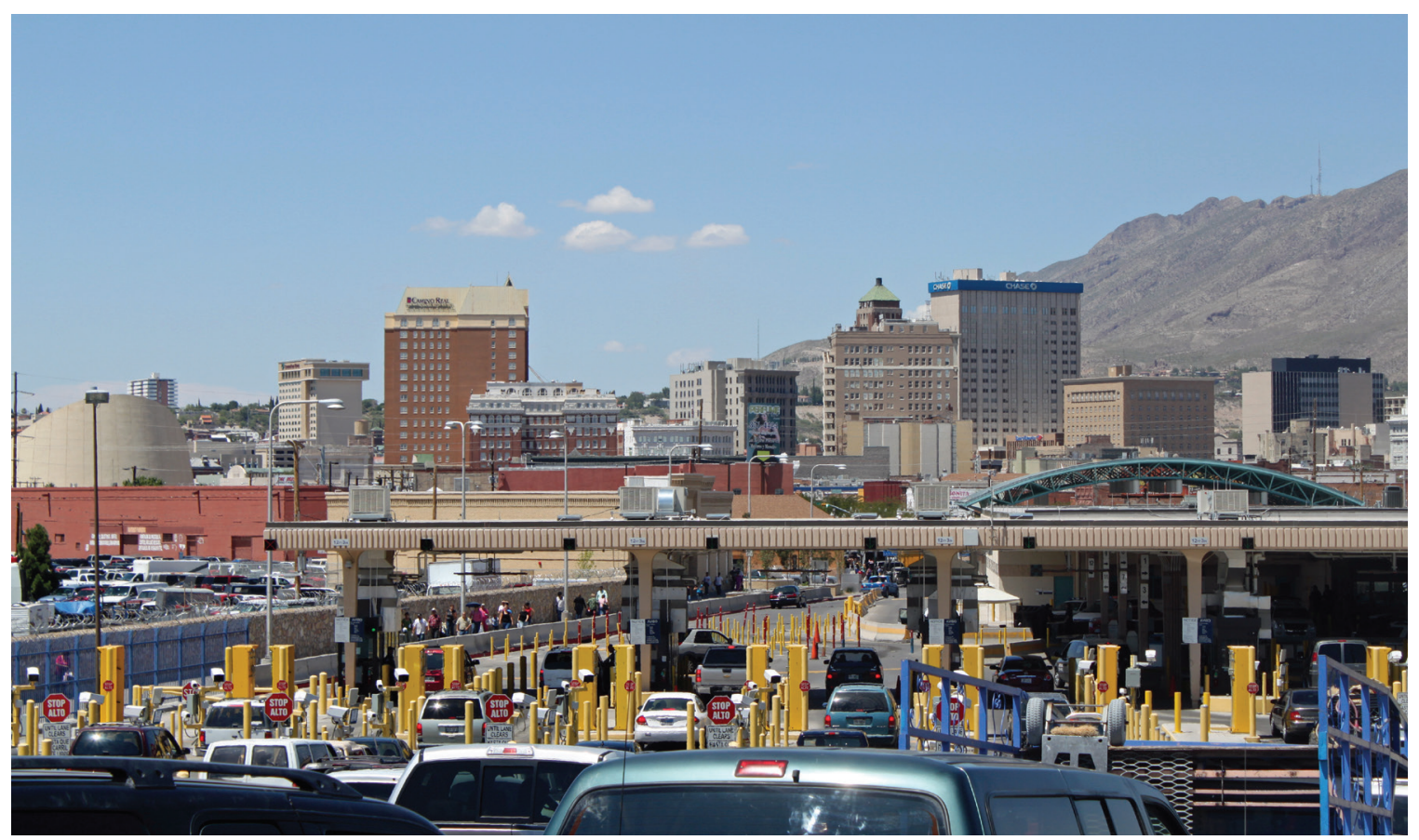

View of El Paso, Texas from the Ciudad Juárez, Chihuahua side of the U.S.-Mexico border. The United States is linked by history, geography, and economics to Latin America. (Flickr/ Astrid Bussinik) 
and innovation. What is clear is that a commoditiesbased export model will not deliver the economic upgrades and fixes needed to transport a country to higher incomes. Diversifying to exports of higher value-added goods is sine qua non. Easy to say, harder to do.

Change is possible. Who would have believed only two decades ago that the policies such as fiscal discipline, tax reform, market dependent interest rates, floating currencies, trade liberalization, and privatization of state enterprises would be seen today as normal? These ideas, then derided as "IMF thinking" and "Washington Consensus," are today the basis of much of the region's economic modernization. It is worthwhile to remember that these changes happened without much political consensus. If Latin America came this far notwithstanding the opposition of powerful political voices, imagine how much further it could move with a broad consensus for change.

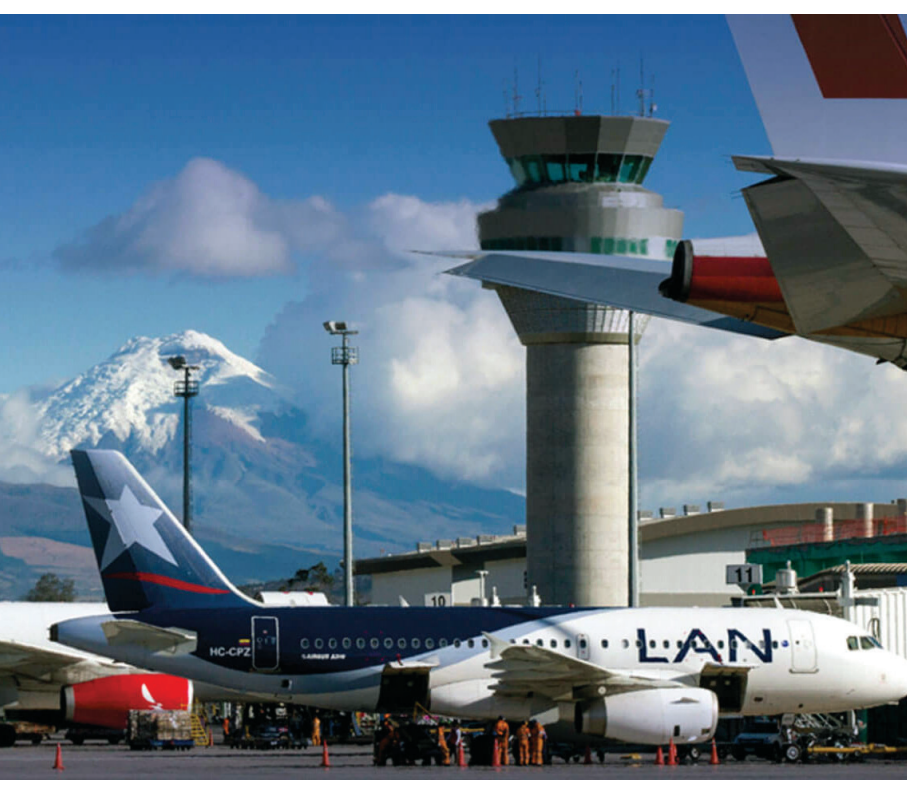

In 2003, OPIC committed $\$ 200$ million in financing to support the construction of the Mariscal Sucre International Airport (Quiport) in Quito, Ecuador. Since opening in 2013, the airport has produced far-reaching benefits from Ecuador to the United States. (OPIC)

\section{With a Little Help from our Friends, High Income is Doable!}

Including Latin America in an arc of confidence starts with expanding the economic bargain.

Democracy and freedom remain in danger without growth. What then might be the cornerstones of a new regional initiative to bring Latin America into the ranks of high income economies? Certainly, the brunt of the work and responsibility must be borne by Latin countries that must continue to reform economies to raise productivity levels, liberalize trade, and open markets. But, there is an important role for the United States as catalyst, investor and cheerleader. Here are the four fundamental pillars of what should be a new U.S. policy for growth in Latin America.

\section{Create a Regional Infrastructure Investment Center}

The Chinese clearly have done some things right through a massive effort, both at home and across the region. With the help of the Chinese, infrastructure transformation in the continent is accelerating. But, needs are still huge. The Economist describes it this way: More than 60 percent of the region's roads are unpaved, compared with 46 percent in emerging economies in Asia and 17 percent in Europe. Two-thirds of sewage is untreated. Poor sanitation and lack of clean water are the second-biggest killer of children under five years old, according to the World Health Organization. ${ }^{24}$ Losses of electricity from transmission and distribution networks are among the highest in the world. Latin America spends a smaller share of GDP on infrastructure than any other region except sub-Saharan Africa. ${ }^{25}$

Infrastructure deficiency reduces productivity and throttles demand. The McKinsey Global Institute predicts that if the infrastructure of the region's middle-income countries were as good as that in Turkey and Bulgaria, their growth rates would be two percentage points higher than they 
are. ${ }^{26}$ The Economic Commission on Latin America estimates that the region needs to invest more than 6 percent of its GDP in infrastructure for 10 years (an estimated $\$ 320$ billion) to eliminate the infrastructure needs gap. ${ }^{27}$ This is far above the current level of investment, as none of the region's economies are currently investing more than 3 percent of GDP in infrastructure. Any new infrastructure investment center should seek to match the government's 3 percent with an equal contribution during the next fifteen years.

There are two ways to implement a new infrastructure center. The first would follow the Chinese model and create a mini-financial institution which could be attached to one of the three multilateral lending institutions-the World Bank, the Corporación Andina de Fomento (CAF) or the IDB. The latter probably is best placed as both a regional institution and also a bank that provides knowledge-based solutions. The second way would be to follow the European Investment Bank's model of providing regional and commercial banks with guarantees for infrastructure investment. Commercial banks do not lend monies for infrastructure because there are no back-up guarantees for these huge expenses. This latter route allows guarantees to leverage private funds.

Either route requires the participation of the private sector. Public-private partnerships (PPP) have been given a bad political name by the onslaught of corruption revelations linking political parties and infrastructure companies such as Odebrecht. But with careful oversight and transparent procurement, PPPs can not only accelerate funds to infrastructure, they can also reduce the cost of infrastructure through expanded competition and less red tape.

\section{Strengthen OPIC and EXIM}

The United States needs to strengthen its economic diplomacy, instead of relying excessively on its military to project American influence. The Overseas Private Investment Corporation (OPIC), which insures U.S. exports against overseas risk and the Export-Import Bank of the United States (EXIM), which provides financing solutions for U.S. exporters are the two principal bilateral bastions of U.S. economic leverage. They help both U.S. exporters and foreign purchasers by facilitating the acquisition of expensive, high-end products.

Both agencies underwent withering attacks by Republican members of congress (with the help of a sprinkling of liberal Democrats) in the final years of the Obama Administration. Michael Lind, a Politico contributing editor, referred to the attacks on EXIM and OPIC as "a study in strategic incompetence." ${ }^{28}$

But 2018 brought an unexpected turnaround. In October, through the sheer willpower of a bipartisan group of legislators and experts, the United States now has a new development finance institution-the U.S. International Development Finance Corporation (DFC). This is an important step-it is the first strengthening of export credit to occur in decades. The DFC will combine OPIC and the U.S. Agency for International Development's (USAID) Development Credit Authority, adding new development finance capabilities, including equity authority, and a higher lending limit than its predecessor. There should be a plan to expand the new agency's programs during the next two decades.

Now is also the time to strengthen EXIM. Indeed, both agencies provide precisely the aggressive economic diplomacy President Donald Trump seems to prefer.

One visit to the EXIM website gives a reader an immediate sense of the power of expanded export credit financing. EXIM credit to a medium sized Peruvian company allowed it to complete a \$1.6 million transaction with a medium sized U.S. company in Indiana. The Chinese call this "win-win" and provide billions in similar transactions to Latin America each year. Indeed, China uses its development bank 
to win allies by financing infrastructure projects and economic development in countries of strategic importance to China's foreign policy goals.

America's overseas development banks, the EXIM and OPIC need to become similarly strategic instruments. And Latin America should be the proving ground for greatly strengthened export facilitation agencies. As an example, only 23 percent of OPIC's portfolio is directed today at Latin America. This should be doubled during the next 15 years.

\section{Integrate North America}

With all three parties exhausted by the negotiations leading up to the renegotiations of NAFTA, (now known as the U.S.-Mexico-Canada Trade Agreement, USMCA), discussions to deepen ties amongst Canada, the United States, and Mexico may seem far-fetched. But, this region's answer to China's OBOR initiative, which accelerates the integration of infrastructure between China and its neighbors, should be an ambitious North American infrastructure project that catapults the continent's prosperity and solidarity. As the United States faces accelerated competition from China (and the EU), the integration of North America's economies will become an urgent imperative. Regional trade amongst the three countries is today a whopping $\$ 1.1$ trillion. Mexico and Canada together account for nearly 30 percent of U.S. trade-China (the largest individual trading partner) is next with 16.4 percent and next in line is Japan at 5 percent. ${ }^{29}$ These large numbers hide the important role of an integrated North American economy for individual states. Canada is, for least 14 states, the number one export destination, conducting more than 30 percent of these states' global two-way trade. Similarly, Mexico is the number one destination for 14 states, moving more than 13 percent of these states' global trade.

We have already seen how increased integration of our economies has made North America energy independent. Pipelines crisscross the borders, moving petroleum products and renewable energy through the three countries' electricity grids. The fact that North America's energy markets have become so much closer has benefited both manufacturers and consumers alike. This has, in turn, accelerated the integration of production chains. Automobiles manufacturing, for example, moves parts and products across borders several times in the construction of a single car.

Now, just imagine more integration. Think, for example, how large, but legal, movement of peoples for seasonal or project labor could effectively contribute to reduced migration. Or, how free and unimpeded movements of goods and services would result in private and public sectors cooperating to upgrade infrastructure in all three countries. Or how large-scale technological improvements at the border could vastly increase trade by permitting a single clearance at one North American border to function as cleared across all North American borders. ${ }^{30}$

Nobody questions the right of the United States to control its borders. But this should not impede greater integration with Canada and the burgeoning middle-class economy that Mexico is becomingremember, by 2050, Mexico will be the fifth or sixth largest economy in the world. We are lucky to have the neighbors we have; let us be smart about the possibilities for U.S. growth and prosperity by lifting its neighbors' boats alongside its own.

\section{Make Latin America's Education an International Priority}

During the past 25 years, Latin America has bet heavily on education as a route to more equitable and prosperous societies. The IDB reports that the region spends about 3 percentage points more of its GDP on education than in the early 1990s. ${ }^{31}$ This number is not that far off from education budgets in countries in the industrialized world. This investment has paid off in some respects: Enrollment in the region has markedly increased across all levels of 
education, with basic education now nearly universal. Citizens in Latin America now see education as a fundamental right.

While access to education has improved, the quality of the offering has gaping holes and should become a central part of how the United States can participate in the improvement of its neighbors' lives. The IDB points out that the region continues to underperform in education-around one out of every three youths does not finish high school. Recent PISA (Program for International Student Assessment) scores reveal that the region has a long road yet to travel; scores in math, reading, and science are highly discouraging. Latin American students rank in the bottom third of all the world's countries. Unemployment among youths in the region during the last two decades has been 15 percent-three times higher than the average unemployment rate among adults. The time is ripe for another exponential jump in Latin America's education investments.

The IDB and the World Bank are the principal organizations expending resources for education. Both institutions support key priorities; school infrastructure (to meet the demand for increasing access to pre-school, to increase science labs in secondary and high schools), teacher education and training, and curriculum transformation to teach skills sought by the private sector, among others.

As the IDB and the World Bank highlight, rising education opportunities increase incomes and social mobility. These are key to reducing inequality and fostering social inclusion. While there is plenty of opportunity to support education expansion, the United States should focus its resources on developing a major workplace skills initiative in the region. Latin Americans understand the importance of education to improve jobs access and retention. Indeed, the IDB describes, vocational training as "a key ingredient to improve lives in Latin America and the Caribbean to face the challenges of this new era." ${ }^{32}$

USAID already supports a plethora of youth workforce programs, higher education efforts, and equitable access projects. Programs to expand and improve vocational training, apprenticeship, and core life skills advance the successful transition from school to work and contribute to positive impacts on the employment quality over the long term. More must be done to support regional private sector-sponsored initiatives to create and sustain youth programs. The United States is perfectly placed to foster public-private partnerships and enhance collaboration between Latin American and American companies to hugely expand vocational programs so that they reach and deliver science, math, and technology skills to larger and more diverse numbers of young people.

\section{Conclusion}

Latin America has more to offer the United States than ever before. Describing the region as a threat is a disservice to Americans, let alone Latin Americans. Fifty-five million U.S. citizens of Latin American descent diversify-and animate-daily life in the United States. They shine in all walks of American life. Without Latinos, Lin-Manuel Miranda would not have written "Hamilton"; Daniel Lubetsky would never have invented KIND ${ }^{\circledR}$ fruit and nut bars; U.S. Supreme Court Justice Sonia Sotomayor could not have written her searing dissents. These are just a few of the millions of successful Latinos in America.

It is unfortunate that the transformation of Hispanics in America or the rapid changes in Latin American countries does not seem to elicit much attention in America. In the minds of too many Americans, the region cannot unglue from the rut of being viewed as a purveyor drugs, crimes, and immigration. Barring a change, that out-of-date stereotype may cost the United States a heavy price. 
There are some unexpected, positive consequences from Latin America's unmooring from the United States. It is true that the America's newfound distance from the region has created an unlikely, new impetus to accelerate integration-particularly between Mercosur countries and the Pacific Alliance nations. Difficult as it may be to imagine given the migration crisis created by millions of desperate Venezuelans, Latin America's newfound self-assurance should create more open borders, greater trade and accelerated regulatory integration in Latin America.

But, meanwhile, other nations, particularly China, are proving that they understand the unique opportunities offered by Latin America. China is wooing Latin America through business, culture, and by showering the region with political attention. It is working; slowly, the region's citizens are becoming convinced that Beijing takes the region more seriously than Washington.

The building of a new partnership—an arc of confidence-with other democratic countries and with our neighbors will require a full-scale effort to move the largest and most important Latin American nations to become high income countries. For the United States, this will be an act of self-interest. It will expand markets and create a more prosperous Americas. Most importantly, it will insure that 640 million Latin Americans continue identify themselves with the hemisphere's common values of democracy, freedom, and inclusion. PRISM

\section{Notes}

${ }^{1}$ Terry M. Neal, "Bush Vows to Push For Stronger Ties To Latin America," The Washington Post, August 26, 2000, available at <https://www.washingtonpost.com/ archive/politics/2000/08/26/bush-vows-to-push-forstronger-ties-to-latin-america/5a15dde4-b1f6-4961-ad93c6d83d19e658/?utm_term=.a49abf7018ad>.

${ }^{2}$ Marisa Arbona-Ruiz, “The 'Despacito' effect: The year Latino music broke the charts," NBC News, December 25, 2017, available at <https://www.nbcnews.com/news/latino/ despacito-effect-year-latino-music-brokecharts-n830131>.

${ }^{3}$ Thomas Anderson, "New Foreign Direct Investment in the United States in 2016," August 2017,retrieved from <https://www.bea.gov/scb/ pdf/2017/08-August/0817-new-foreign-direct-investment-in-the-united-states.pdf>; Adrian B. Estévez,"The Latin American Foreign Investment Boom: Recent Trends And the Evolution of Multilatinas,"(Wilson Center Mexico Institute, June 11, 2015), available at <https://www.wilsoncenter.org/publication/ the-latin-american-foreign-investment-boom-recent-trends-and-the-evolution-multilatinas $>$; United Nations Conference on Trade and Development (UNCTAD), World Investment Report 2018:Investment and New Industrial Policies, June 2018, available at https://unctad.org/en/PublicationsLibrary/ wir2018_en.pdf $>$.

${ }^{4}$ Margaret Myers,"Does China Understand Latin America Better than the U.S.?"China-US Focus, February 2018, available at <https://www.chinausfocus.com/ foreign-policy/does-china-understand-latin-america-better-than-the-us>.

${ }^{5}$ David Brunnstrom, Matt Spetalnick, and Jon Herskovitz, "Latin America Should Not Rely on China: U.S. Secretary of State Tillerson,”ed. Chizu Nomiyama and Grant McCool, Reuters, February 2018, available at <https://www.reuters.com/article/ us-usa-diplomacy-latam-china/tillerson-warns-latin-america-against-reliance-on-china-idUSKBN1FL6D5>.

${ }^{6}$ Gonzalo Sebastian Páz, "China, United States and Hegemonic Challenge in Latin America: An Overview and Some Lessons from Previous Instances of Hegemonic Challenge in the Region," The China Quarterly 209 (March 2012), 18-34, retrieved from <http://www.jstor.org/stable/41447820>; Gaston Fornes and Alvaro Mendez, The China-Latin America Axis: Emerging Markets and their Role in an Increasingly Globalized World, 2nd ed. (Cham, Switzerland: Spring International Publishing, 2018).

${ }^{7}$ Michael Reid, "China Moves Into Latin America," The Economist: Bello, February 3, 2018.

${ }^{8}$ China-CELAC Forum notes, June 2018, retrieved from <http://www.chinacelacforum.org/eng/zyxw_1/>.

${ }^{9}$ Felipe Iturrieta, "Chile Praises China's 'constructive Role' at Latin American Forum," Reuters, January 2018, available at <https://www.reuters.com/ article/us-chile-china/chile-praises-chinas-constructive-role-at-latin-americanforum-idUSKBN1FA185>.

${ }^{10}$ Michael Reid "China Moves into Latin America," The Economist: Bello, February 3, 2018.

${ }^{11}$ Rebecca Ray, 2018 China-Latin America Economic 
Bulletin, Discussion Paper No. 2018-1, April, 2018, available at <http://www.bu.edu/gdp/2018/04/04/2018-china-latin-america-economic-bulletin/>.

${ }^{12}$ Stephen B. Kaplan, "The Rise of Patient Capital: The Political Economy of Chinese Global Finance," July 24,2018 , available at $<$ https://ssrn.com/abstract $=3108215>$.

${ }^{13}$ Rebecca Ray, 2018 China-Latin America Economic Bulletin.

${ }^{14}$ Jorge Guajardo, Manuel Molano, and Dante Sica, "Industrial Development in Latin America: What is China's Role?", Atlantic Council Adriennne Arhst Latin America Center, August 29, 2016, available at <http:// www.atlanticcouncil.org/publications/reports/industrial-development-in-latin-america-what-is-china-s-role $>$.

15 The Economist, "China Establishes Renminbi Clearing Bank in Chile," Intelligence Unit (online), June, 2015, available at <http://www.eiu.com/industry/ article/1493221333/china-establishes-renminbi-clearing-bank-in-chile/_9>; Meng Meng and David Stanway,"China Central Bank Appoints ICBC as Argentina RMB Clearing Bank," September 18, 2015, Reuters, available at <https://www.reuters.com/article/ china-rmb-argentina-idUSB9N11K01O20150918>.

${ }^{16}$ Douglas W. Arner and Andre Soares, "A Globalized Renminbi: Will It Reshape Latin America?” Atlantic Council, October 1, 2016, available at <http://www.publications.atlanticcouncil.org/renminbi/index.php $>$.

${ }^{17}$ United Nations Economic Commission of Latin America and the Caribbean (ECLAC), Exploring New Forms of Cooperation between China and Latin America and the Caribbean, United Nations Document LC/ TS.2018/6 (United Nations: Santiago, Chile, January 2018). ${ }^{18}$ Ibid.

${ }^{19}$ Margaret Myers and Kevin Gallagher, "Down But Not Out: Chinese Development Finance in LAC," The Dialogue: Leadership for the America, March, 2018, available at <https://www.thedialogue.org/resources/ chinese-finance-to-latin-america-and-the-caribbean-in-2017/>.

${ }^{20}$ David B.H. Denoon, ed.,China, The United States, and the Future of Latin America Vol. 3, U.S.-China Relations (New York: New York University Press, 2017).

${ }^{21}$ Office of the United States Trade Representative, "Free Trade Agreements," February 6, 2018, available at $<$ https://ustr.gov/trade-agreements/ free-trade-agreements $>$.

${ }^{22}$ Daniel Runde, "Colombia is Ready to Join the Club," Foreign Policy, April 3, 2018, available at <https://foreignpolicy.com/2018/04/03/ colombia-is-ready-to-join-the-club/>.

${ }^{23}$ James Stavridis, "Six Steps on a Path to Latin American Strategy," Bloomberg,
February 6, 2018, available at <https://www. bloomberg.com/view/articles/2018-02-06/ six-steps-on-the-path-to-a-latin-america-strategy $>$. 24 "Latin America Needs and Infrastructure Upgrade," The Economist, March 10, 2018, available at <https://www.economist.com/the-americas/2018/03/10/ latin-america-needs-an-infrastructure-upgrade $>$.

${ }^{25}$ Ibid.

${ }^{26}$ Andrés Cadena, Jaana Remes, Nicolás Grosman, and André De Oliveira, "Where Will Latin America's Growth Come From?” McKinsey Global Institute, April 2017, available at <https://www.mckinsey.com/ /media/ McKinsey/Featured Insights/Employment and Growth/ How to counter three threats to growth in Latin America/ MGI-Discussion-paper-Where-will-Latin-Americas growth-come-from-April-2017.ashx>.

${ }^{27}$ Patricia Krause, Time to Address the Infrastructure Gap in Latin America, September 8, 2017, COFACE Economic Publications, available at <http://www.coface. com/News-Publications/Publications/Time-to-addressthe-infrastructure-gap-in-Latin-America $>$.

${ }^{28}$ Michael Lind, "Cold War II, National Review, May 10, 2018, available at <https://www.nationalreview.com/ magazine/2018/05/28/us-china-relations-cold-war-ii/>.

${ }^{29}$ United States Census Bureaue, “Top Trading Partners-December 2017," available at <https://www. census.gov/foreign-trade/statistics/highlights/top/ top1712yr.html>.

${ }^{30}$ This excellent idea was raised in the Council of Foreign Relation's Independent Task Force Report \#71. David Petraeus, Robert Zoellick, and Shannon O'Neil, North America: Time for a New Focus, (New York: Council on Foreign Relations, 2014).

${ }^{31}$ Matías Busso and Steven Ambrus, "Latin America, the Caribbean and PISA: The Long Road Ahead." IDB: Ideas Matter, December 13, 2016, available at <https:// blogs.iadb.org/ideasmatter/2016/12/13/latin-america-thecaribbean-and-pisa-the-long-road-ahead/>.

${ }^{32}$ Matías Busso, Julián Cristia, Diana Hincapié, Julián Messina, and Laura Ripani, ed. Learning Better. Public Policy for Skills Development, August, 2017, (Washington, DC: Inter-American Development Bank, 2017), available at <https://publications.iadb.org/ handle/11319/8495>.

\section{Photos}

Page 12. Licensed under Creative Commons Attribution-ShareAlike 3.0 Unported License. Photo produced unaltered.

Page 19. Licensed under Creative Commons Attribution 2.0 Generic License. Photo unaltered. 


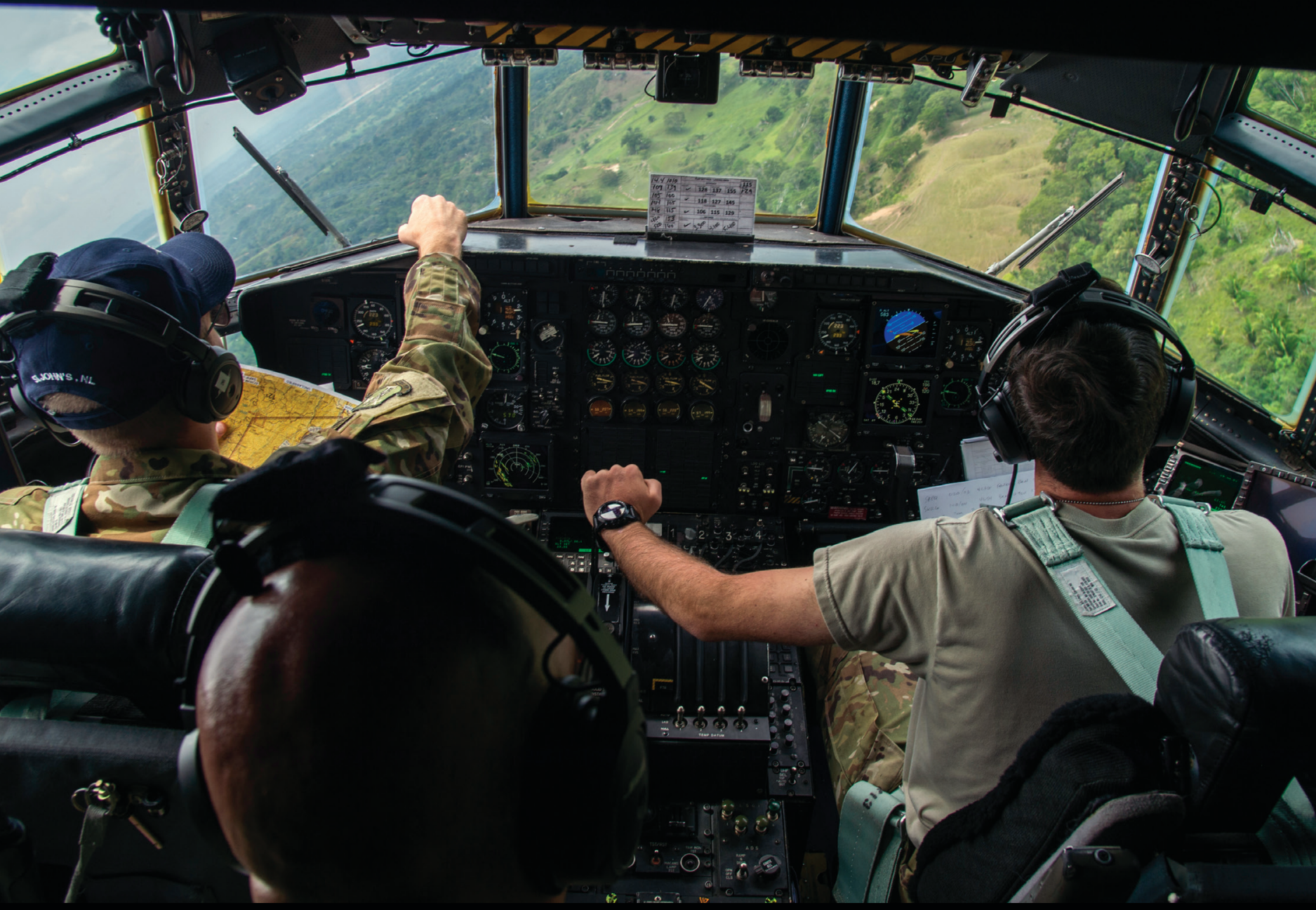

In September 2018, U.S. C-130 Hercules pilots conduct low altitude flying maneuvers over Colombia during the Colombianled search and rescue exercise Angel de los Andes. (U.S. Air Force/ Angela Ruiz) 


\section{The U.S. Military in Support of Strategic Objectives in Latin America and the Caribbean}

By R. Evan Ellis

$\mathrm{S}$ ince the end of the Cold War, Latin America and the Caribbean have received a relatively minimal portion of personnel and resources allocated globally by the U.S. military. ${ }^{1}$ Such allocations are understandable, given that there are no major interstate wars or state rivals in the region presenting a conventional or nuclear threat to the United States. ${ }^{2}$ Yet the absence of such challenges has led to an unfortunate paucity of thinking about the strategic roles and potential contributions of the U.S. military in Latin America, and other regions where the threat of major armed conflict is limited or absent.

The 1991 collapse of the Soviet Union arguably reduced the strategic significance for the United States of Marxist insurgencies such as those in Peru, Colombia, Nicaragua, and El Salvador, and the associated importance of helping governments in the region to combat them. The evaporation of ideologically-based state funding for such groups, and their increasing reliance on drug and other criminal revenues enabled by their control over territory, redirected the U.S. military focus in the region to a struggle against narcotrafficking that was far removed from missions that had traditionally defined the size and structure of U.S. forces, even as the U.S. military wrestled to "transform" in the post-Cold War context. ${ }^{3}$ The Global War Against Terrorism with substantial military engagement in Iraq and Afghanistan, further decreased attention from U.S. military thinkers to challenges in Latin America, as the focus of combat units, and associated planning, intelligence, training, and materiel requirements shifted to the Middle East. Later the rise of the People's Republic of China (PRC) and the "Pivot Toward Asia" diverted even more of the U.S. military's attention from Latin America. ${ }^{4}$

That there has not been a major U.S. military intervention in the Latin America and Caribbean region for 24 years, since Operation Uphold Freedom in Haiti in September 1994, has further compounded neglect. ${ }^{5}$ There are few serving U.S. military personnel with experience in, let alone charged with, planning for a major force deployment and the conduct of kinetic operations in the region. Indeed, apart from the remote possibility of U.S. military intervention in Venezuela, it is difficult to imagine a justifiable nearterm scenario for such operations. ${ }^{6}$

While the absence of major interstate conflicts and near-term military threats from regional competitors is a bright spot in the context of the challenges of criminal insecurity, corruption, and inequality that plague

Dr. R. Evan Ellis is a research professor of Latin American Studies at the U.S. Army War College Strategic Studies Institute. 
Latin America, from a U.S. military perspective, such good news has translated into a relative lack of thinking among security planners regarding the role of U.S. armed forces in the region, and in other regions like it, where the prospect of large-scale combat operations is relatively slim. ${ }^{7}$

This lack of recent experience is consistent with the region's often unrecognized strategic importance to the United States. Yet no other geographical region is as directly tied to U.S. security and prosperity than Latin America and the Caribbean, considering the intimate bonds of geography, commerce, and family. As seen by the U.S. domestic political discourse over immigration, Central American street gangs, and the risk of terrorists entering the United States across the nation's southern border, while Latin America may not receive priority as an "international relations" issue, the dynamics of the region are so important that they regularly play a decisive role in U.S. domestic politics. ${ }^{9}$

The region's under-recognized strategic importance adds gravity to the relative absence of strategic thinking by military planners about the region. And because, in the short term at least, major conventional military operations are highly unlikely in the region, there is little incentive to dedicate limited analytical resources to the potential strategic contributions of the U.S. armed forces to integrated engagement in the region.

Even merely discussing a strategic role for the U.S. military in the region evokes discomfort among our regional partners. On the other hand, the types of activities that the U.S. military can and regularly does conduct in Latin America (such as training and medical missions, engineering, and other civil affairs work), are often regarded by the mainstream U.S. military as secondary to more "serious" military activities in other theaters such as the Middle East and Asia.

This article seeks to fill that gap by examining the role that the U.S. military plays, and can play, in advancing U.S. strategic objectives in the region, with a focus on security cooperation and administration of security assistance efforts, as part of a coordinated whole-of-government approach. It argues for greater U.S. military attention to the development and application of strategic concepts built around strengthening governance, as the approach that is both appropriate to sensitivities and limitations regarding the employment of U.S. armed forces in Latin America, and as an effective bulwark against the cycle of criminality, corruption, and populism that opens the door for significant strategic threats against the United States. These include authoritarian anti-U.S. governments that serve as enablers for widespread criminality, terrorist threat networks, and collaboration with hostile extra-hemispheric state actors such as Russia and the PRC.

\section{The Role of the U.S. Military in Latin America}

Given the absence of a near-term military threat from a peer competitor in Latin America and the Caribbean, and in the context of historically-rooted sensitivities regarding direct military action by U.S. forces, the optimal U.S. military activity for achieving national objectives in the region has generally been security cooperation and civil affairs activities, and the administration of Department of State (DOS)-funded security assistance. It is thus imperative for American analysts and policymakers to understand the strengths and limitations of these tools in the Latin American context if they are to be employed in an optimal manner.

For the purposes of this article, security cooperation corresponds to the broad array of activities described by Joint Publication 3-20:

all Department of Defense (DOD) interactions, programs, and activities with foreign security forces... and their institutions to build relationships that help promote U.S. interests; enable partner nations to provide 
the United States access to territory, infra-

structure, information and resources, and/or to build and apply their capacity and capabilities consistent with U.S. defense objectives. ${ }^{10}$

By contrast, security assistance refers to a broader set of programs or activities generally involving the "providing of defense articles, military training and other defense-related services" (to include initiatives to reform or improve a partner nation's security sector). ${ }^{11}$ By law, security assistance is funded and controlled by the DOS, but may be administered by DOD in-country consistent with the partner country's security expertise and capabilities; it thus also may be considered part of the legitimate, albeit not widely recognized, uses of the military instrument in Latin America and the Caribbean.

The most important characteristics of security cooperation and security assistance in determining its effective use in Latin America and the Caribbean (and elsewhere) are the balance between its relational effects and indirect action, and the distinction between near-term and long-term strategic effects.

\section{Relational Effects vs. Indirect Action}

While not often thought of in such terms, security cooperation, security assistance, and other non-traditional military activities discussed herein have two complementary, but distinct channels for achieving effects: relational and indirect action.

Relational effects refer to the contribution of working together, or providing benefits to the partner military, in building bonds of goodwill, trust, influence, or gratitude. By doing something for (or with) the partner, the U.S. military hopes that the partner will behave in some desired fashion. This might include cooperating with respect to something that the U.S. military wishes its partner to do, including providing U.S. military forces use of partner nation facilities, sharing intelligence, or alternatively not cooperating with entities hostile

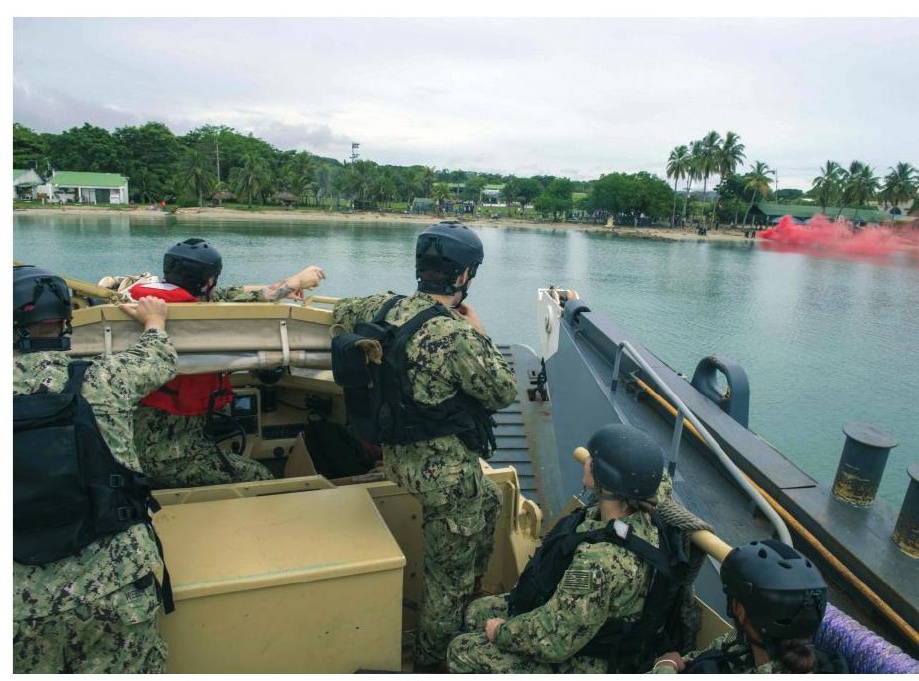

In September 2018, a landing craft utility prepares to land on the beach in Cartagena, Colombia for a humanitarian assistance training exercise during UNITAS - a longstanding multi-national maritime exercise conducted annually in Latin American and the Caribbean to enhance security cooperation and improve coalition operations. (U.S. Navy/ Colbey Livingston)

to U.S. interests (such as the Chinese, Russians, Cubans, or criminal groups). ${ }^{12}$ America's use of terrain in Honduras for Joint Task Force Bravo (JTF-B) and part of the airfield at Comalapa, El Salvador are examples of relational effects.

With respect to indirect action, through the United States providing intelligence, equipment, training, or other benefits, the partner is able to perform some particular activity or function that benefits U.S. objectives, without the U.S. having to do so itself. The contribution of Colombia to the training of Central American security forces through the Colombia Action Plan is one example of indirect action.

Working through partner nations is inherently less predictable than acting directly. Moreover, the determinants of success in achieving effects through relational channels, vice indirect action are different. In the relational sphere, achieving effects depends on the degree to which the partner is motivated to cooperate (whether through expectation 
of continuing benefit, affinity, or fear), rather than whether the cooperation provided actually benefits the partner's institution, although providing real benefits is generally a reliable way to secure a partner's cooperation, and engagement which does not provide enduring benefits (such as bringing partner nation officers to the United States for an attractive trip to attend a military education event that is often of poor quality) may eventually backfire.

By contrast, the effectiveness of security cooperation and assistance as indirect action depends on the quality of the benefit, such as training a competent partner nation force which can prevail against insurgents or terrorists, or combat drug traffickers, relieving the United States from having to conduct such action on its own (avoiding the politically sensitive issue of operating on the partner nation's soil).

While good security cooperation and assistance ideally achieves both relational effects and indirect action, in structuring a program, it is useful to be clear on the mix of objectives to make appropriate choices about difficult tradeoffs. If the strategic goals of the cooperation are mostly relational (e.g. base access, Organization of American States voting, intelligence-sharing, or blocking partner cooperation with China), it is arguably more important to be liked (or feared) than to have truly useful programs. Indeed, analysts often miss this distinction when dismissing Chinese security cooperation programs in the region because they do not seem to be particularly useful, but miss the impact of offering Latin American officers' lucrative trips to Beijing and Shanghai with good food, side trips to the Great Wall, and other perks.

\section{Near-Term versus Long-Term Effects}

Beyond the distinction between relational effects and indirect action, it is important to distinguish between near-term effects of security cooperation and assistance on the partner nation unit being trained or supported, versus the more diffuse, longer-term impacts on the partner nation's institutions or its strategic or political orientation more broadly. While most security cooperation and assistance involves both, measures of program completion and success generally focus on near-term effects (persons trained, competence demonstrated), or at the least, do not credibly measure the long-term benefits (such as partner nation senior officials who believe in the merit of a U.S.-style approach involving rule of law and transparent processes, corruption free institutions, a relatively secure, prosperous country), which may represent the far greater strategic payoff of such cooperation. ${ }^{13}$

In U.S. joint doctrine, the effects of security cooperation are discussed in terms of building partnerships, building partner capacity, and gaining and maintaining access to the theater for U.S. forces; yet for the purpose of formulating effective whole-of-government strategic concepts, it is important to recognize the important albeit indirect ways in which such activities contribute to specific U.S. national security interests. ${ }^{14}$ Specifically:

- blocking a conventional threat to the United States;

- blocking a terrorist threat to the United States;

- stopping illicit and dangerous flows to the United States;

- combatting strategic instability and radical undemocratic alternatives; and

- blocking strategic economic and political advances of external state actors into the region.

\section{Blocking a Conventional Threat to the United States}

Since the end of the Cold War, no U.S. competitor has positioned forces in Latin America or the Caribbean so as to pose a credible threat to the U.S. homeland. Nonetheless, in the event of a global conflict with a rival such as the PRC, the later could employ its commercial investments in the region, in 
fields such as shipping, ports, banking, electronics, and manufacturing to project and sustain intelligence agents and other operatives in Latin America, with the purpose of collecting information on the United States, attacking or impacting the United States through commercial and financial activities in Latin America, or securing entry into the United States from the region. ${ }^{15}$

In the event of a protracted military conflict, the PRC or other adversaries could leverage knowledge and influence from political and military relationships and commercial operations to employ ports, airfields, or other facilities in the region in military operations in the region against U.S. targets.

In such an eventuality, the U.S. military would likely respond directly against the country or countries permitting the use of facilities, although such actions could be too little too late. Prior to such hostilities, however, the U.S.-partner nation military-to-military relationship would be key in deterring and blocking any such attempts by the PRC or any other adversary. Such resistance might involve relational effects, such as partner nation senior defense officials with both personal affinity for the United States and sincere professional belief that resisting cooperation with China is in their national interest, as are transparent, resilient institutions resistant to such vulnerabilities as bribery or personal compromise by PRC agents.

With respect to indirect action, Chinese incursions might be thwarted by sharing intelligence with the United States, and effectively acting with the United States upon information concerning threats. The partner relationship with the United States would also be important in conducting effective resistance or diversionary operations in the event that the country was coopted by the PRC (or any foreign power) in a military conflict with the United States.

Blocking a conventional threat also highlights the importance of achieving synergy between security cooperation engagement by the U.S. military, and more conventional military activities. The motivation of local partners to report incursions by extra-hemispheric actors, at considerable risk to their personal security and the political position of their country, and their commitment to struggle with the United States against those incursions in the period leading up to, and during a conflict, will be strongly influenced by the perception that the United States is capable of, and willing to defend them (and take action if those partners permit the use of their territory against the United States). Apart from the goodwill, trust, and capability for coordinated action that comes from security cooperation, the decisions of partner nations, and specific individuals in them, will generally reflect the U.S. level of commitment visible in a capable U.S. force, and through the signals the U.S. gives when sustaining the costs of standing by its partners in other situations, both in Latin America and other parts of the world.

\section{Blocking a Terrorist Threat to the United States from the Region}

Preventing Latin America and the Caribbean from serving as a staging ground for a terrorist action against the U.S. homeland or its residents goes beyond the effective border control necessary to insulate the homeland from threats from individuals or minor devices. It also requires effective action by partners in the region (and by the United States where appropriate) to identify, degrade, dismantle, and block terrorist threat networks, including recruitment, planning, training, the acquisition or construction of weapons, or the raising of revenues (from licit or illicit sources) in the region.

While countering such terrorist activities may principally be a law enforcement function, the U.S. military may play a role in passing intelligence, and in equipping, training, and otherwise strengthening the capabilities of security forces in the region, to include the supervision of police and other programs as part of Department of State-led security assistance efforts, 
increasing the capability of partner nation security forces to combat such threat networks. Where permitted by national laws and political conditions, U.S. engagement may also include direct action against threats, conducted in coordination with partner nation forces, where consistent with their policies, laws, and constitutional frameworks.

As with countering threats from external state actors, the U.S. military may also contribute to the fight against such networks by supporting strong governance in partner nations by helping to reform and strengthen institutions and processes through programs such as the Defense Institution Reform Initiative (DIRI) and the Ministry of Defense Advisors (MODA) program. DIRI, for example, recently helped Guatemala to develop a new national security planning and capability development process, SIPLAGDE. According to Major General Juan Manuel Pérez Ramírez, former Chief of the Joint Staff of Guatemalan Armed Forces, the vision was to use SIPLAGDE, working together with the United States and Colombia as partners, to systematically resolve capability gaps and achieve the modernization and transformation of the Guatemalan Army. ${ }^{16}$

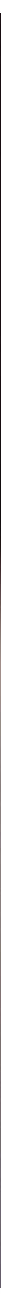

In October 2018, a cadet from the Mexican Air Force Academy sits in the co-pilot seat on a C-17 Globemaster III at the U.S. Dover Air Force Base. Last year, 22 cadets from 11 different Latin American countries were brought to the United States to get hands-on experience with the different branches of the U.S. military. (U.S. Air Force/ Zoe M. Wockenfuss) 
SIPLAGDE, and other security cooperation and security assistance programs may not only bolster partner nation institutional capabilities in identifying and combatting violent extremist organization networks but may also build bonds of trust that bolster partner nation willingness to cooperate with the United States in areas such as intelligence, and (where permitted by the partner nation) joint operations against them.

Such efforts may also include civil affairs activities aimed at bringing connectivity and economic opportunity to regions of partner countries deprived of opportunities other than collaboration with criminal groups and other actors of concern, helping the state to physically assert its own presence and build relations with the population, so as to reduce the space in which threat groups operate.

As a further indirect benefit in combatting threat networks, the institutional relationship, including exercises, training and professional military education of partner nation forces, ideally strengthens the commitment of the partner nation military to democracy and rule of law, limiting the latitude of populists and other regimes to engage in criminal activities that permit such threat networks to flourish. ${ }^{17}$

\section{Blocking Illicit Flows into the United States}

The role of U.S. armed forces in blocking illicit and dangerous flows to the United States is not unlike their indirect (and sometimes direct) contributions in the fight against violent extremist organizations and other threat networks. ${ }^{18}$ As when working against terrorist threat networks, the U.S. military may combat transnational criminal networks through the training, education, and equipping of partner nation security forces, sharing of intelligence, joint exercises, and in some cases direct action (as always, only where permitted by the partner nation) to more effectively control borders, interdict such flows, and counter associated threat groups.
The strong relationships built through security cooperation, and the commitment to democracy and rule of law, may be particularly important when security forces are obliged to act against a politically or economically influential criminal actor, or conduct security operations that impose economic costs, or generate collateral violence, such as occurred in Mexico during the war against the cartels. ${ }^{19}$

As with the fight against terrorist networks, military civil affairs activities, performed in coordination with other security assistance and partner nation activities, impair the ability of criminal groups to produce and move drugs, mining products, and other contraband through the region. These activities also discourage trafficking and smuggling people into the United States, through strengthening state presence and the critical bond with the population, thus increasing law enforcement effectiveness, and creating a culture in which adherence to the law is at least a viable, respectable option.

\section{Combatting Strategic Instability and Anti- Democratic Alternatives}

In addition to directly combatting and reducing the threat to the United States from terrorist and criminal networks, U.S. military engagement may reduce the risk of strategic instability and associated refugee flows that could impact the United States, or adversely impact governance and conditions in other countries in the region..$^{20}$ The primary vehicles for achieving these effects are security cooperation and administration of security assistance activities that strengthen partner nation institutions, as well as civil affairs and other efforts that bring stability, connectivity, and economic opportunity to critical areas of the partner nation.

In some cases, military engagement may include emergency response activities, coordinated through the U.S. Office of Foreign Disaster Assistance (OFDA), addressing natural disasters 
which threaten the well-being and even governance of a stricken nation. Examples include hurricanes such as Irma (2017), the Haiti (2010) and Ecuador (2016) earthquakes, and the eruption of Guatemala's Fuego volcano (2018). This could also potentially include man-made shocks which threaten the stability of the region, for example assisting Venezuela's neighbors as they struggle with the more than 2.3 million persons who have fled from that nation's economic collapse, criminal violence, and political repression. ${ }^{21}$ While such efforts may be bilateral, they may also be part of a multinational effort, coordinated through the OAS or another institution.

Beyond the tactical and operational level impacts of such assistance, and its role in strengthening good-will and trust, it potentially serves U.S. strategic interests by helping to inoculate receiving states against radical or anti-democratic solutions which find receptivity when populations lose faith in the ability of a democratic political system and a free market economy to effectively address the corruption, inequality, injustice, and other dysfunctionalities plaguing their country.

While helping partner nations avoid radical undemocratic alternatives is good on principle, it also strategically benefits the United States, since, as seen in cases such as Venezuela, Cuba, Bolivia, and Nicaragua (and previously Ecuador), such governments tend to be anti-U.S. in character, and open the door for threat networks, criminal groups, and hostile extra-hemispheric actors.

\section{Blocking Advances of External Actors}

Beyond responding to overt military threats by external state actors in the region, the U.S. military also plays an important, albeit indirect role in resisting their strategic advances in the economic and political domains. It does so principally by contributing to partner nation stability and wellbeing, as discussed above, although U.S. military engagement that reduces susceptibility to corruption in partner nation security institutions plays a contributing role.

By helping partner nations successfully address the challenges of insecurity and development through democratic mechanisms and the rule of law, U.S. security cooperation and oversight of security assistance make radical anti-democratic political solutions, less attractive and thus less

likely. While leftist populist governments such as in Venezuela are not the only ones at risk of deepening economic dependence on, and political influence of China, such governments arguably have both a greater economic need, and political disposition to take relationships with external states further, in ways that can threaten U.S. equities, while corruption and authoritarian structures in their institutions make them more vulnerable to Chinese advances. ${ }^{22}$

On the other hand, when healthy democratic partner nations engage with the PRC, institutions strengthened in part through anti-corruption initiatives and other U.S. security cooperation and security assistance oversight will be more likely to secure transparent deals from China that benefit 
the partner, without presenting substantial security challenges to the United States.

\section{Good Governance: A Key Strategic Concept for U.S. Military Engagement}

All of the vehicles for employing the U.S. armed forces in an integrated, whole-of-government effort to achieve U.S. objectives in Latin America and the Caribbean center on security cooperation efforts and security assistance oversight that strengthens effective governance. ${ }^{23}$ Good governance makes countries more effective in tackling, and more resistant to the corrupting effects of, violent extremist organizations and other threat networks, including criminal groups that would employ partner nation territory to move people and illicit goods to the United States.

Good governance also reduces vulnerability to populists who exploit the frustration and ignorance of marginalized and other voters, fed up with elites who use corruption to seize power, then use the power of their mobilized followers to gradually overcome checks and balances and subvert democratic institutions and processes. It further restricts the tendency of such leaders, whose actions isolate their countries from Western companies, banks, and governments, to plunge their countries into relationships of dependency with China, in ways that challenge their own security as well as that of the United States and of the region.

In an international environment in which the countries of Latin America are increasingly globally interconnected, the United States cannot effectively block them from engaging with the PRC (among other external state actors), but through helping to strengthen their governing institutions, it can help to inoculate those nations against China's more predatory behaviors, such as winning economic and strategic benefits by wooing, compromising, and capturing local elites.

While the U.S. military is not the lead agency in advancing governance in the region, as argued in the previous section its security cooperation and security assistance administration efforts are a valuable component of the overall U.S. integrated country strategy. ${ }^{24}$

\section{Challenges to the Effective Use of the Military}

While governance is a compelling strategic concept, with a clear supporting role for the U.S. military, the advance of external state actors in the region, coupled with persistent insecurity, uneven development, weak governance and leftist populism, clearly indicate that much work remains to be done.

It is not that the U.S. military does not do activities such as security cooperation and security assistance administration in the region; rather, it does not adequately understand the dynamics and limitations of such activities, nor does it effectively integrate with non-military programs and partner nation efforts. Nor does it adequately resource them or execute them in an agile, timely fashion.

\section{Limited Understanding}

The U.S. military is, by its nature, focused on organizing, preparing the force for, and conducting large-scale combat operations in defense of the nation. It is not principally a foreign training and public works organization. Joint Publication 3-20 "Security Cooperation" provides some guidance for security cooperation and security administration assistance, yet beyond periodicals such as Dialogo, and publications oriented toward security cooperation professionals such as the Foreign Area Officers Association Journal of International Affairs, thinking within the mainstream military regarding the contribution of such activities has arguably been limited, particularly in the Latin American and Caribbean context. ${ }^{25}$

Combatant Commander strategies include references to security cooperation and security assistance as a vehicle for shaping the theater, yet it is not clear that there is a shared understanding within 
USNORTHCOM and USSOUTHCOM regarding how that shaping mechanism functions, or how well it is working, beyond measuring security cooperation activities completed, and a subjective survey completed by the organization responsible for the action. ${ }^{26} \mathrm{~A}$ DOD presentation explaining a change in funding authorities, for example, acknowledged a lack of "understanding of the security cooperation return on investments and lack of information to facilitate effective resource decisions." ${ }^{27}$

The lack of understanding also obscures the perceived benefits of scaling up security cooperation and security assistance and increases the risk of errors and inefficiencies, as arguably occurred with "nation building" efforts in Iraq and Afghanistan. ${ }^{28}$

\section{Limited Resources}

In 2015, then Commander, U.S. Southern Command General John Kelly, in his posture statement before Congress, lamented the status of the region as the "lowest priority" among all of the Geographic Combatant Commands, and argued that the lack of resources allocated to the region had created "a near-total lack of awareness of threats and the readiness to respond." ${ }^{29}$ Unlike numerous states in the Middle East and Asia, Latin America and its member countries are not even mentioned in the 2019 National Defense Authorization Act. ${ }^{30}$

In most countries of the region, the funds available for U.S. security cooperation are scarcely adequate to do more than send a handful of partner nation officers to U.S. military training and professional military education institutions, do a limited number of in-country training events via entities such as the U.S. Special Forces $7^{\text {th }}$ Group, DIRI, or the William J. Perry Center, conduct a small exercise and/or deploy a medical (MDRDTE) team, and send in a small number of civil affairs team (generally affiliated with the U.S. National Guard state partner for that country). Country Security Cooperation Offices (SCOs) in the region are limited to very small foreign military sales or financing cases, such as acquiring or outfitting a small number of boats for counternarcotic missions, putting sensors on a handful of military aircraft, or providing or upgrading armored vehicles. Such assistance is seldom sufficient to truly make a difference to beleaguered partners with often aging, marginally functional assets, struggling against enormous illicit flows and well-resourced criminal and terrorist groups.

\section{Limits on the Use of Military Resources}

For a number of entirely legitimate reasons, the employment of the U.S. military instrument in Latin America is subject to significant legal and policy constraints. According to Title 22, section 2151 of the U.S. Code, with only limited exceptions, all foreign assistance (including security assistance) is the responsibility of the U.S. State Department. ${ }^{31}$ Within those areas in which DOD security assistance and other forms of engagement are permitted, it may not train or engage with military units or other Latin American entities implicated in human rights violations- "Leahy laws"- the compliance with which imposes time-consuming requirements to vet units to be trained. ${ }^{32}$

Governing laws (principally within Title 10 and 22 of U.S. Code) also establish legal restrictions on how certain U.S. government funds can be used in support of military activities with or for the partner nation. ${ }^{33}$ These include the conditions that must be met, components of the program that must be included, and often burdensome reporting requirements. Title 22, section 333 of U.S. Code, for example, was amended by Chapter 16 of the 2017 National Defense Authorization Act, adding additional requirements for human rights training and reporting requirements. ${ }^{34}$ Such well-intentioned requirements not only limit the commander's flexibility to most effectively employ often very small allocations of money to advance country objectives, 
but in practice, create a situation in which country teams spend more time on internal paperwork than actually engaging with and supporting their partners in the often rapidly changing contexts of the partner nation environment.

Such requirements also significantly increase the delay between the identification of a partner nation need that can be addressed through security assistance, and actual program implementation. The design and implementation of a program using Section 333 program funds, for example, is a twoyear cycle, but in practice, the time from identifying a need to delivery of the capability to the partner nation may be three or four years. ${ }^{35}$

The regulations and bureaucratic procedures of the U.S. Foreign Military Assistance and Foreign Military Financing (FMS/FMF) programs are similarly problematic, leading some U.S. partners to prefer purchasing military equipment from the Russians, Chinese, or other actors, rather than suffer the delays and administrative hurdles necessary to obtain superior U.S. equipment with superior maintenance and training packages.

\section{The Path Forward}

There is significant opportunity for innovative thinking regarding the role of the military in advancing U.S. national objectives through security engagement. This is particularly true in Latin America, where the direct importance of the region to the security and prosperity of the United States is substantial, but the need for, and appropriateness of traditional military engagement is limited.

As a first step, it is important for the military and other personnel engaged in security assistance to draw upon their experiences to publish more case studies and comparative analyses, not only in journals directed toward their own community such as the Foreign Area Officers Association Journal of International Affairs, but also for mainstream military publications such as the U.S. Army's Parameters, PRISM, and Military Review. There is also a need for foreign area officers and others implementing security cooperation programs and overseeing security assistance, to dedicate more time during their professional military education (such as time spent at senior service institutions), and in other assignments, to more systematically study the dynamics and effects of such engagement for the benefit of others in their profession, and for the U.S. military and government team more broadly.

As a complement to better leveraging those with experience in this area, it is important that DOD senior service colleges include more or expanded modules on the dynamics and effect of security cooperation, particularly since at the strategic level, such engagement touches on the success of virtually every operation in which they are involved.

Beyond academics, it is also important for those in security cooperation offices in Latin America and the Caribbean, and elsewhere, to resist the pressures of time and competing requirements, to ensure that the words that they put on the "quad charts" and other documentation defining and justifying their programs, actually correspond to reasonable outcomes for their programs, and that those programs collectively, in conjunction with the other items in their integrated country plans, represent a coherent, mutually reinforcing series of effects that advance U.S. objectives in the country. Personal attention from the Ambassador, and the SCO chief on the military side in highlighting the importance of serious thought behind such program documentation assignments, and periodically reviewing the claims of past documents against program outcomes, would create a forcing function for the level and quality of thought for future programs.

Finally, it is necessary to address the two 800-pound gorillas in the room-resources and authorities. No U.S. Government agency nor DOD combatant command has the money and legal 
latitude to do everything that it wants, in the way that would be most convenient. But in the context of serious challenges to U.S. national security from the region from a combination of external state actors, transnational criminal organizations, and extremist groups, among others, the status quo, which General Kelly referred to as keeping a "pilot light" of military engagement on in the region, is unacceptable. ${ }^{36}$ An order-of-magnitude expansion in security assistance to the region, intelligently designed and executed, and greater latitude in dynamically designing and executing programs with partner nations, must be considered.

In the end, perhaps the greatest obstacle to the effective employment of security engagement as a military instrument in Latin America, the Caribbean, and elsewhere, is not recognizing it as a military instrument, because it does not correspond to the conventional concept of force-on-force engagement, nor are its uses and benefits well understood. Understanding how to do so is critical to achieve security in the region on whose prosperity and effective governance the United States depends, and in the process, more effectively utilizing all dimensions of the military as an instrument of national power. PRISM

\section{Notes}

${ }^{1}$ The views expressed herein are strictly those of the author, who would like to thank COL Phil Cuccia, among others, for their inputs into this work. Commander of U.S. Southern Command Admiral Kurt Tidd, opened his posture statement with references to the area as an "economy of force" command. See: "Posture Statement of Admiral Kurt W. Tidd Commander, United States Southern Command Before the 115th Congress, Senate Armed Services Committee," February 15, 2018, available at <http://www.southcom.mil/Portals/7/Documents/ Posture\%20Statements/SOUTHCOM_2018_Posture_ Statement_FINAL.PDF?ver=2018-02-15-090330-243>.

${ }^{2}$ The last interstate conflict was the limited 1995

"Cenepa war" between Peru and Ecuador. See James Brooke, "Peruvians at Disadvantage in Border War," The New York Times, February 8, 1995, 10.

${ }^{3}$ See, for example, Russell Crandall, Driven by Drugs, 2nd Ed (Boulder, CO: Lynne Rienner, 2008).

${ }^{4}$ Michael J. Green, "The Legacy of Obama's

"Pivot" to Asia," Foreign Policy, September 3, 2016, available at $<$ https://foreignpolicy.com/2016/09/03/ the-legacy-of-obamas-pivot-to-asia/>.

${ }^{5}$ Edwidge Danticat, "The Long Legacy of Occupation in Haiti," The New Yorker Magazine, July 28, 2015, available at <https://www.newyorker.com/news/news-desk/ haiti-us-occupation-hundred-year-anniversary>.

${ }^{6}$ Shannon K. O'Neill, “A U.S. Military Intervention in Venezuela Would Be a Disaster," Council on Foreign Relations, September 18, 2018, available at $<$ https://www.cfr.org/article/ us-military-intervention-venezuela-would-be-disaster>.

${ }^{7}$ See, for example, Nathalie Alvarado, "Why is There So Much Crime in Latin America?" Insight Crime, November 3, 2015, available at <https://www. insightcrime.org/news/analysis/why-is-there-somuch-crime-in-latin-america/>. See also R. Evan Ellis, Transnational Organized Crime in Latin America (New York: Lexington Books, 2018).

${ }^{8}$ See R. Evan Ellis, "The Strategic Importance of the Western Hemisphere-Defining U.S. Interests in the Region." Testimony before the Subcommittee on the Western Hemisphere, U.S. House of Representatives Foreign Affairs Committee, available at $<$ http://docs. house.gov/meetings/FA/FA07/20150203/102885/HHRG114-FA07-Wstate-EllisE-20150203.pdf>, February 3, 2015.

${ }^{9}$ Dan Nowicki, "Immigration at front of 2016 presidential race," USA Today, May 15,2015 , available at $<$ https://www.usatoday. com/story/news/politics/elections/2015/05/15/ immigration-2016-presidential-race/27360717/>.

${ }^{10}$ Joint Publication 3-20: Security Cooperation, May 23, 2017, available at <http://www.jcs.mil/Portals/36/ Documents/Doctrine/pubs/jp3_20_20172305.pdf >, vii.

${ }^{11}$ Ibid.

${ }^{12}$ Ibid.

${ }^{13} \mathrm{Ibid}$.

${ }^{14}$ Ibid, II-2-3.

${ }^{15}$ See R. Evan Ellis, "China’s Activities in the Americas," Testimony before a joint hearing of the Subcommittee on the Western Hemisphere and the Subcommittee on Asia and the Pacific, U.S. House of Representatives Foreign Affairs Committee, September 10, 2015, available at <http://docs.house.gov/meetings/ FA/FA07/20150910/103931/HHRG-114-FA07-WstateEllisE-20150910.pdf>.

${ }^{16} \mathrm{E}$-mail correspondence with the Major General in fall 2018

${ }^{17}$ See, for example, Sabrina Martin, "Hezbollah Announces Support for Venezuelan Vice President 
El Aissami to Take over from Maduro," Panam Post, August 9, 2017, available at $<$ https://panampost.com/sabrina-martin/2017/08/09/ hezbollah-announces-support-for-venezuelan-vice-president-el-aissami/?cn-reloaded $=1>$.

${ }^{18}$ For the purpose of this work, illicit and dangerous flows include drugs, arms, human smuggling and trafficking, and other contraband activity, as well as the destructive side effects from the insufficiently controlled movement of people and goods, including disease, incidental criminal activity, and economic and social disruption.

${ }^{19}$ See Max Fisher and Amanda Taub, "Análisis: El récord de la violencia en México es una crisis que comenzó hace 20 años," The New York Times, October 28, 2017, available at $<$ https://www.nytimes.com/es/2017/10/28/ violencia-mexico-interpreter-homicidios-record/>.

${ }^{20}$ Nina Lakhani, "Central America's rampant violence fuels an invisible refugee crisis," The Guardian, October 13, 2016, available at <https:// www.theguardian.com/world/2016/oct/13/ central-america-violence-refugee-crisis-gangs-murder $>$.

${ }^{21}$ Ishan Tharoor, "Venezuela's refugee exodus is the biggest crisis in the hemisphere," Washington Post, August 23, 2018, available at $<$ https:// www.washingtonpost.com/world/2018/08/23/ venezuelas-refugee-exodus-is-biggest-crisis-hemisphere/?noredirect=on\&utm_term $=.9 \mathrm{clb} 908 \mathrm{e} 3 \mathrm{bfe}>$.

${ }^{22} \mathrm{See}$, for example, R. Evan Ellis, "The evolution of Panama-PRC relations since recognition, and their strategic implications for the US and the region," Global Americans, September 21, 2018, https:// theglobalamericans.org/2018/09/the-evolution-of-panama-prc-relations-since-recognition-and-their-strategic-implications-for-the-u-s-and-the-region/; and R. Evan Ellis, "The Influence of Extra-Hemispheric Actors on the Crisis in Venezuela," U.S. House of Representatives Committee on Foreign Affairs, Subcommittee on the Western Hemisphere, September 13, 2017, available at <http://docs.house.gov/meetings/ FA/FA07/20170913/106398/HHRG-115-FA07-WstateEllisR-20170913.pdf >.

${ }^{23}$ See also R. Evan Ellis, "US Smart to Assist Latin America With Democratic Governance," Newsmax, August 10, 2018, available at $<$ https:// www.newsmax.com/evanellis/democratic-governance-latin-america-strategy/2018/08/10/ id/876479/>.

${ }^{24}$ Joint Publication 3-20: Security Cooperation.

${ }^{25}$ Ibid.

${ }^{26}$ Ibid, vii.

27 "FY17 NDAA Chapter 16 \& Section 333,"
Presentation by U.S. Southern Command, Reviewed September 20, 2018.

${ }^{28}$ See, for example, T.X. Hammes, "Raising and Mentoring Security Forces in Afghanistan and Iraq," in Lessons of the Long War, Richard D. Hooker, Jr. and Joseph J. Collins, Eds. Washington D.C.: National Defense University Press, 2005, 277-344.

29 "Posture Statement of General John F. Kelly," Senate Armed Services Committee, 114th Congress, March 12, 2015, available at $<$ https://www.armed-services.senate.gov/imo/media/doc/Kelly_03-12-15.pdf>. 30 "H.R. 5515: John S. McCain National Defense Authorization Act for FY 2018," GovTrack, available at $<$ https://www.govtrack.us/congress/bills/115/hr5515/text $>$.

${ }^{31} 22$ U.S. Code $\$ 2151$, available at $<$ https://www.law. cornell.edu/uscode/text/22/2151>.

${ }^{32}$ See "Leahy Fact Sheet," U.S. Department of State, March 9, 2018, available at <https://www.state.gov/j/drl/ rls/fs/2018/279141.htm>.

${ }^{33}$ See, for example, $115^{\text {th }}$ Congress 2 nd Session, H.R. 5515Report No. 115-676, April 13, 2018, available at <https://www.gpo.gov/fdsys/pkg/BILLS-115hr5515rh/ pdf/BILLS-115hr5515rh.pdf >.

34 "National Defense Authorization Act of Year 2017," Public Law No: 114-328 S.2943, 114 ${ }^{\text {th }}$ Congress, 2016, available at $<$ https://www.armed-services.senate.gov/imo/ media/doc/FY17\%20NDAA\%20Bill\%20Summary.pdf >; These include a more extensive specification of measurable objectives and evaluation of return on investment from partner nations. See "FY17 NDAA Chapter 16 \& Section 333," Presentation by U.S. Southern Command, Reviewed September 20, 2018.

${ }^{35}$ Off-the-record interview by the author with U.S. security cooperation officials, September 2018.

36 "Posture Statement of General John F. Kelly," Senate Armed Services Committee, 114thCongress, March 12, 2015, https://www.armed-services.senate.gov/ imo/media/doc/Kelly_03-12-15.pdf. 


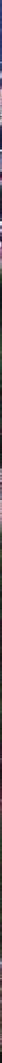

Thousands of Venezuelans have fled to Colombia, straining the Colombian government's ability to police its 1,300 mile border. (Moises Rendon) 


\title{
The Venezuelan Crisis and Salvador Allende's Glasses
}

\author{
By Juan S. Gonzalez
}

$\mathrm{T}$ here is a sculpture in the Venezuelan foreign ministry that conveys the die-hard ideology of those who in a relatively short period have managed to transform a vulnerable but nonetheless pluralistic democracy into an autocracy in the throes of economic collapse and humanitarian calamity. The work, Nunca Mas (Never Again) or Sin Nombre (Without Name), by Chilean artist Carlos Altamirano symbolizes the glasses worn by former Chilean President Salvador Allende, which were found broken in half and cracked following his death during the military coup of 1973. To any foreigner visiting the Venezuelan foreign ministry, the sculpture seems to say, "You won't take us alive."

Such symbolism serves as an important reminder that-despite having wrestled with Venezuela for nearly two decades - the United States still does not fully understand the internal dynamics of the regime or to what ends it will go to ensure its survival. Should the United States invade Venezuela or support another military coup? Has the international community exhausted diplomatic options? This article provides a brief history of what led to Venezuela's political and economic collapse, outlines the dangers of intervention, underscores the importance of a Venezuelan-led resolution to the current stalemate between the government and the opposition, and prioritizes the need to address the humanitarian situation along with the country's debt crisis as tools to pressure the government.

\section{What Chavismo has Wrought}

The Venezuelan political crisis has been nearly two decades in the making. Upon assuming power in 1999, Hugo Chavez and his loyal band of chavistas began to implement an ambitious strategy for consolidating political control, with lasting impacts on Venezuelan civilian and military institutions. Charismatic and omnipresent, Chavez blurred the distinction between government, party, and state to destroy the existing political order, undermine the country's institutions, and strengthen his own personal authority. ${ }^{1}$ His "Bolivarian Revolution" sought to replace capitalism with so-called $21^{\text {st }}$ Century Socialism and

Mr. Juan S. Gonzalez is an Associate Vice President at The Cohen Group and Senior Fellow at the Penn Biden Center for Diplomacy and Global Engagement. He served previously as Deputy Assistant Secretary of State for Western Hemisphere Affairs and as Special Advisor to U.S. Vice President Joe Biden and National Security Council Director for the Western Hemisphere. 
traded representative democracy for a system of participatory democracy designed to empower the Venezuelan citizenry. Traditional parties struggled to unite and organize an effective response to Chavez, which allowed him to win election after election by polarizing and radicalizing the opposition. Even when Nicolas Maduro assumed power in 2013 by the thinnest of margins, the opposition was unable to maintain unity long enough to capitalize on his low level of popularity and the impacts of economic mismanagement.

In the 2011 edition of their book on Chavez, Dragon in the Tropics, Javier Corrales and Michael Penfold define chavismo as a hybrid regime, where the mechanisms for determining access to state office combine both democratic and autocratic practices with the following characteristics:

- Government negotiations with opposition forces are rare;

- Die-hard loyalists of the government are placed at top-level positions;

- The state actively seeks to undermine the autonomy of civic institutions;

- The law is invoked mostly to penalize opponents but seldom to sanction the government;

- The incumbent changes and circumvents the constitution; and

- The electoral field is uneven, with the ruling party making full use of the benefits of incumbency that are denied to the opposition.

In practice, chavismo successfully neutered the press by prosecuting journalists, closing down television stations, harassing regional media, and concentrating government advertising with friendly media. Chavez controlled the private sector through active nationalizations, intimidation, and price controls. The influence of the church was neutralized by shifting government funding for social, health, and school programs toward local chavista organizations, and by challenging the independent curricula of church-run schools.

The Venezuelan military also became increasingly politicized. Chavez expanded its role under the 1999 constitution by providing political and institutional autonomy to the armed forces under the command of the President. ${ }^{2}$ The new constitution granted the military the right to vote and the government passed laws reaffirming its role in maintaining internal order. Chavez appointed military officers to roughly a third of cabinet portfolios and took a hands-on approach to military promotions to ensure loyalists rose through the ranks. These and other actions produced a split within the military between those officers who remained loyal to the traditional order and others who benefited from the Bolivarian Revolution.

It was this split that some analysts believe guaranteed the regime's survival during a failed coup attempt in 2002, during which the military high command briefly removed Chavez from power. ${ }^{3}$ Following the attempt, Chavez purged military officers who came out against the regime and the government expanded its efforts to indoctrinate the military with Bolivarian fervor by linking military identity to the ideological precepts of the governing party. ${ }^{4}$ Chavez placed loyalists in command of strategic positions around Caracas and around opposition strongholds, including the Presidential Honor Guard, the $3^{\text {rd }}$ Division Command at Fort Tuina in Caracas, the $42^{\text {nd }}$ Paratrooper Infantry Brigade in the state of Aragua, and the $21^{\text {st }}$ Brigade in San Cristobal, Tachira.

The government also created parallel security structures, known as colectivos to safeguard the Bolivarian Revolution. ${ }^{5}$ These pro-government vigilante groups became part of the neighborhood-based "communal councils" created in 2006 to oversee community development projects, through which the colectivos became armed, received support from the state, and enjoyed legitimacy in 
their areas of operation. ${ }^{6}$ According to the government, there are at least 100,000 armed members of these bands throughout Venezuela. Some have even received training from the Revolutionary Armed Forces of Colombia (FARC). ${ }^{7}$ According to former Cuban intelligence officials, others were sent for training to Cuba, which by this point had begun to play an increased role in the Venezuelan military and as advisors to the regime. ${ }^{8}$

Under chavismo, corruption and criminality also went from having a presence to acquiring a controlling stake in the Venezuelan government. Rampant corruption and the breakdown of institutional checks and balances in Venezuela created a permissive environment for drug trafficking and led to the rise of the Cartel de los Soles (Cartel of the Suns), a cartel led by senior Venezuelan officials, including possibly then-National Assembly President Diosdado Cabello. ${ }^{9}$ According to former U.S. Ambassador to Venezuela William R. Brownfield, criminal groups have also coopted the government's social programs, its security services, and intelligence organizations. ${ }^{10}$

Internationally, the Bolivarian Revolution led to the creation in 2004 of the anti-U.S. Bolivarian Alternative for the Peoples of Our America (ALBA) that proposed $21^{\text {st }}$ Century Socialism as an alternative to the democracy and free trade agenda of successive U.S. Administrations. ${ }^{11}$ As a coalition of countries, the original members of ALBAAntingua and Barbuda, Bolivia, Cuba, Dominica, Ecuador, Grenada, Nicaragua, Saint Kitts and Nevis, Saint Lucia, Saint Vincent and the Grenadinesallowed Chavez to polarize the continent in the same way he did Venezuela.

Until its zenith in late 2009, ALBA countries proved effective at introducing chaos and undermining the agenda at hemispheric fora such as the Summit of the Americas and the Organization of American States (OAS) General Assembly. Chavez also implicated Venezuela in conflicts outside its borders, by providing safe haven and support to illegal armed groups, like the FARC, and by allying with regimes in Iran, Russia, and Syria.

After Chavez's death in 2013, Maduro defeated opposition leader Henrique Capriles with a margin of just less than 1.5 percent. Instead of sitting down with the more pragmatic elements of the Venezuelan opposition to work toward common cause, Maduro moved quickly to consolidate power by centralizing his authority within his United Socialist Party of Venezuela (PSUV) and by eliminating any remaining semblance of democratic order in Venezuela. The government escalated repression by confronting protestors with deadly force and giving free reign to violent colectivos. It eliminated the freedoms of the press and assembly necessary for legitimate political debate; and demonized and arrested political opponents, including political leader Leopoldo López, who was arrested during a peaceful protest and sentenced without proof in 2015 to nearly 14 years of prison for the laughable crime of inciting violence through "subliminal messages." Hundreds of protesters have been killed and thousands arrested.

When the opposition won the majority of the National Assembly seats in 2015, Maduro circumvented the authority of the legislature. When more than 1 million Venezuelans took to the streets in September 2016 to demand a recall referendum, the government used the National Electoral Council (CNE) to block and delay the signature drive, and ultimately banned protests in $2017 .{ }^{12}$ The government also decreed new elections for a loyalist Constituent Assembly to supplant the legislature and to rewrite the Venezuelan constitution. Maduro was re-elected in May but the process was condemned by the international community, including OAS Secretary General Luis Almagro, who accused Maduro of trying to "give a democratic veneer to his totalitarian regime." ${ }^{\prime 3}$ One could argue that at this point the Maduro government is not even trying to pretend to be democratic. 


\section{Economic and Humanitarian Dimension of the Crisis}

Even before Hugo Chavez, successive Venezuelan governments struggled to manage the country's oil wealth, but $21^{\text {st }}$ Century Socialism managed to destroy the country's economy despite a sustained oil boom that then drove the country over a fiscal cliff once prices dropped.

Literature on the resource curse (where resource rich countries have performed worse than resource poor ones) has evolved from the 1950s inward-looking development models of Import Substitution and Industrialization (ISI) to today's research on the economic challenges of managing resource booms, including the political economy of poor economic policies. ${ }^{14}$ There are notable examples of developing and middle countries, like Botswana, Chile, and Malaysia, that appear to have escaped the curse through a long-term view on the allocation of royalties, expert management of investment decisions, and insulation from political forces. Government commitment to transparency and accountability, due process, and prudent public financial management have also been key. ${ }^{15}$ There are also many counter-examples of developing or transitional economies that, despite sizeable oil and gas reserves, have been unable to manage resource revenues effectively to stimulate development and reduce poverty.

And then there is Venezuela under chavismo. Venezuela has the world's largest proven oil reserves, which account for a majority of its exports. ${ }^{16}$ Proceeds from oil sales provide nearly all of the foreign exchange necessary to fund the government and allow the government to import consumer goods, but also make the country vulnerable to the ebbs and flows of the oil market. Rather than inoculate the country against the whims of the commodity cycle through countercyclical economic policies and an apolitical process for managing resource revenues, Chavez' Venezuela squandered an oil windfall through poor economic policies and rampant corruption. The result is one of the worst economic and humanitarian crises ever in Latin America, while simultaneously mortgaging the country's oil industry to China and Russia for years to come.

The beginning of the Chavez era in 1999 coincided with an oil recovery following an extended lull in prices, which he leveraged to transform Venezuela's oil industry into a tool of executive power. Under his tenure, Venezuela's oil sector became politicized, the economy returned to import substitution-era statism, and the government developed a voracious appetite for expropriation. ${ }^{17} \mathrm{He}$ appointed loyalists to the board of Venezuela's national oil company (PDVSA) and merged the Ministry of Energy and Mines and PDVSA under a single leadership.

Following an oil workers' strike in 2003, he fired an estimated 20,000 thousand PDVSA workers, prompting an exodus of talent to neighboring Colombia, the Caribbean, and others parts of the world. Chavez also diverted PDVSA funds away from exploration and infrastructure upkeep toward unsustainable Bolivarian social missions. The government also raided PDVSA's coffers to fund international petro-diplomacy through the 2005 launch of Petrocaribe, a regional financing mechanism that had greatest impact and influence in the Caribbean and Central America, two sub-regions with high-energy prices, poor fiscal budgets, and relatively weak institutions.

The strategy seemed to work while oil prices were high. According to the Economic Commission for Latin America and the Caribbean, the percentage of the population living under the poverty line in Venezuela fell from 49.4 percent in 1999 to 27.8 percent in 2010. Unemployment dropped from 14.5 percent to 7.5 percent between 1999 and 2009 and GDP per capital rose from $\$ 4,105$ to $\$ 10,801$ during that same period. ${ }^{18}$ Internationally, Petrocaribe's off-book agreements and suitcases filled with cash allowed Venezuela 
to buy regional influence and become the dominant political force in the Caribbean. ${ }^{19}$

Though masked by the oil windfall, the government's policies set Venezuela on an accelerated course toward economic ruin. From 2000 until Chavez's death in 2013, the government increased spending as a share of GDP from 28 to 40 percent, depleting currency reserves from being able to cover over seven months of imports to just under three months. ${ }^{20}$ Underinvestment in the oil industry resulted in a production drop from 3.5 million barrels per day ( $\mathrm{mn} \mathrm{bpd}$ ) at the start of the Chavez era to $2.8 \mathrm{mn}$ bpd in $2012 .{ }^{21}$ Meanwhile, oil dependency increased from 77 percent of export revenue to more than 96 percent today. ${ }^{22}$ The Venezuelan economy began to contract in 2014, and the sharp drop in oil prices to $\$ 30$ at the beginning of 2016 accelerated the country's economic crisis. ${ }^{23}$

Efforts by the Maduro administration to get a handle on the economic situation represent a case study in what not to do: it maintained an overvalued official exchange rate and rationed imports. To gain access to dollars, importers had to prove they were trying to bring something of value into the country. Efforts to control prices drove the growth of the black market and prompted manufacturers to cut production. In an unprecedented step to skirt U.S. sanctions and attempt to control inflation, the government issued a new currency backed by cryptocurrency. ${ }^{24}$ Most recently, the government has allowed private banks to sell dollars and tightened requirements for citizens to use banking services from outside the country. None of this will resolve the damage inflicted on the Venezuelan economy.
In 2018 alone, the International Monetary Fund (IMF) expects the country's GDP to fall by 15 percent and inflation to increase by up to 1 million percent. Poverty levels have spiked to between 70-80 percent, depending on the source. Grocery store shelves are bare, medicine is scant, and violence is rampant. Oil production now stands at just more than $1 \mathrm{mn}$ bpd, which is insufficient to meet contractual obligations. ${ }^{25}$ More than 2 million Venezuelans (roughly 7 percent of the population) have fled the country, according to UN figures.

All the while, the Venezuelan kleptocracy made out like bandits. Stories abound about the so-called boliburgueses - the Bolivarian bourgeois-flying in private planes, buying property in Miami, and sending their children to prestigious U.S. universities. Or, if you are Maduro, you stop in Istanbul on your way back from Beijing to eat a $\$ 275$ steak at Salt Bea. ${ }^{26}$ More troubling are the numerous examples of embezzlement from the

Venezuelan Treasury, like government officials embezzling at least $\$ 300$ billion just through the currency control system, or FinCen's March 2015 discovery that Venezuelan third-party money launderers had bribed Banca Privada d'Andorra to launder $\$ 2$ billion in funds siphoned from PDVSA. ${ }^{27}$ In July, members of a ring of former Venezuelan officials and businessmen were charged in Miami with operating a $\$ 1.2$ billion international money-laundering operation with funds embezzled from PDVSA. ${ }^{28}$ Those are just some of the known cases.

Today, the complexity of Venezuela's debt dynamics has set up an eventual showdown between the Paris Club, China, and Russia. Venezuela has 
largely gone out of its way to meet its debt obligations, even if it meant forgoing the purchase of food and basic goods, until on November 2017 it was forced to default on over $\$ 6$ billion in debt payments. Overall, the International Institute for Finance (IIF) estimates that Venezuela's public external debt totals approximately $\$ 150$ billion, and the servicing requirements on that debt amount to between $\$ 5$ billion and $\$ 7$ billion in each of the next five years, which the country cannot afford. In an effort to initiate debt negotiations, Venezuelan Vice President Tareck El Aissami convened a meeting with creditors last November that some attendees characterized as "bizzare" in that it lasted roughly 30 minutes and consisted of El Aissami devoting his intervention to criticizing the Trump Administration but offering no concrete proposals for debt restructuring. ${ }^{29}$

The challenge for

Venezuela is that U.S. sanctions have all but closed Venezuela's access to international financial markets, which would normally lead to a discussion on restructuring with the Paris Club, except for the fact that China and Russia have become alternative finance mechanisms for Venezuela. Since 2005, China has provided more than $\$ 150$ billion in loans to Latin America and the Caribbean, the majority of which ( $\$ 62.2$ billion) has gone to Venezuela's energy industry. ${ }^{30}$ China is Venezuela's largest creditor, holding \$23 billion in the country's debt, mostly backed by oil deliveries. China continues to provide lifelines to Venezuela, most recently by providing a total of $\$ 10$ billion in credit lines for oil development in June and September. ${ }^{31}$
Russia's Rosneft has also served as a lender of last resort for Venezuela, loaning PDVSA approximately $\$ 6$ billion guaranteed by oil and a 49.9 percent stake in U.S.-based subsidiary CITGO. Following Venezuela's default, Russia stepped in by agreeing to restructure $\$ 3.15$ billion in debt. ${ }^{32}$ Russia is a member of the Paris Club and China is not, but both will have significant leverage over Venezuela in any restructuring discussions.

\section{U.S.-Venezuela Relations and the International Response}

The U.S.-Venezuela relationship can be divided into two parts: before and after the 2002 attempted coup. The bilateral relationship deteriorated sharply following swift U.S. recognition of Pedro Carmona during the attempted coup of 2002 , along with reports of meetings between U.S. officials and plotters. ${ }^{33} \mathrm{With}$ the United States as the foil, Chavez capitalized on the confrontational nature of the relationship as a cover to accelerate his Bolivarian project at home and to divide the countries of Latin America and the Caribbean into pro- and anti-U.S. blocs. Through much of the 2000s, U.S.-Venezuela tension, and the U.S. policy of with-us-oragainst-us-ism dominated the hemispheric agenda and thus raised Chavez's profile.

It was not until the end of the Administration of George W. Bush, when Thomas A. Shannon became Assistant Secretary of State for Western Hemisphere Affairs that U.S. policy assumed a more strategic approach to Venezuela. Under Shannon, the United States set aside 
megaphone diplomacy and public sparring with the Venezuelan government, instead internationalizing the response through multilateral organizations. It did not attack Chavez directly, but rather focused on the vulnerable points of his strategy in terms of democratic breakdown, human rights violations, and poor economic management. Ambassador Brownfield engaged and made inroads in chavista strongholds. This approach was successful in creating the public space necessary for the Venezuelan people to engage in an active debate about the future of their country.

The Bush and subsequently the Obama Administration also undertook a concerted effort to improve the U.S. relationship with Latin America's left-leaning populist governments-Bolivia, Ecuador, Nicaragua, and Venezuela-to advance cooperation on matters like drug trafficking, where the United States held a particular interest. At the same time, by selectively engaging with ALBA countries, rather than treating them as a bloc, U.S. diplomats were able to undermine its very coherence by dispelling historic notions of U.S. Manichaeism, reducing the regional appeal of problematic leaders, and bolstering constructive regional actors.

By emphasizing multilateralism, while simultaneously seeking common ground with anti-U.S. governments, the United States provided an answer to arguments that efforts to engage with outliers undercut a strong commitment to democracy and human rights. It also addressed a longstanding complaint that U.S. policy treated allies-no matter how undemocratic-differently than those who opposed the United States. Further, the Obama Administration's shift in focus toward strengthening and broadening the base of the region's democracies by helping those countries working to bolster transparent and accountable institutions, regardless of their political ideology, helped to bolster the region's democratic development models, and provided a compelling contrast between the freedom, security, and prosperity of people in those countries, and the increasing instability and challenges to freedom in the region's illiberal democracies.

The Obama Administration took an even more forward leaning approach in the second term, with a historic change in policy toward Cuba and with Vice President Joe Biden as lead diplomat for the Americas. Biden raised the profile of U.S.-Mexico economic cooperation through the High-Level Economic Dialogue and engaged in personal shuttle diplomacy to repair the U.S.-Brazil relationship following the cancellation of the Brazil State Visit in the wake of the Edward Snowden disclosures in 2013. ${ }^{34}$ To win back the Caribbean from Venezuela, he launched the Caribbean Energy Security Initiative to marshal an international response to prepare the region for the end of Venezuelan petropolitics. U.S. policy during this time demonstrated an understanding of the limitations of attempting to shape political dynamics inside Venezuela, as well as demonstrated that the most effective way to address the deteriorating political situation inside Venezuela was to encircle Venezuela through a comprehensive regional approach.

One critique of the Obama Administration's policy toward Venezuela was that, while successful in marginalizing ALBA, it did little to prevent Venezuela's rapid deterioration after Nicolas Maduro assumed power. In fact, with Maduro in power, the United States focused its diplomatic efforts on supporting a regional solution through the Union of South American States (UNASUR) and the auspices of the Vatican. Venezuela insisted on having UNASUR mediate between the government and the opposition, but there was a fundamental misalignment between the United States and UNASUR regarding the desired outcome that doomed the effort from the beginning: whereas the United States sought a democratic outcome as part of any resolution to the country's growing political and economic crisis, UNASUR (driven by Brazil 
and remnants of ALBA) defined stability in terms of continuity and regime survival. It is unclear whether Maduro was prevented from making concessions to the opposition by more radical elements within chavismo, or whether he insisted on UNASUR as the dialogue facilitator in order to drag on talks and prevent escalated pressure from the United States. In practice, the talks dragged on without progress while Maduro worked in parallel to dismantle the opposition and to strengthen his grip on power.

The White House did shift gears in 2015 by empowering the Departments of Justice and Treasury to more aggressively sanction money launderers, human rights abusers, and drug traffickers inside the government. The result was the March 8, 2015 Executive Order (E.O.) that went beyond the requirements established by the Venezuela Defense of Human Rights and Civil Society Act of 2014 by providing Treasury with the necessary prongs to target public corruption and human rights abuses in parallel with the State Department's continued efforts to pursue diplomatic options. ${ }^{35}$ It was this E.O. that laid the groundwork for the Trump Administration's approach.

While one could argue stronger enforcement actions should have taken place in early 2013 before

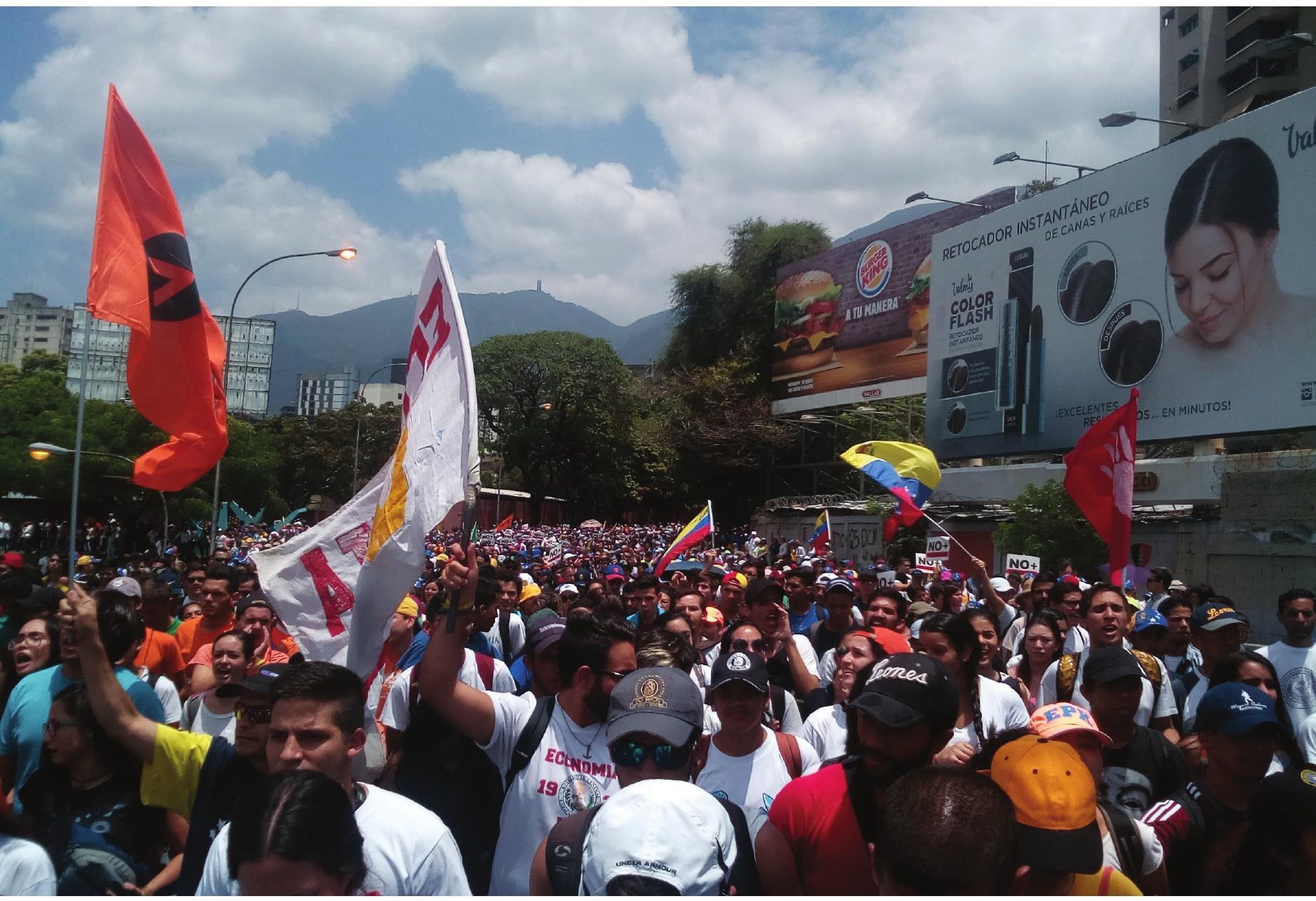

Protests in Venezuela, April 6, 2017. (Wikimedia/Jamez42) 
Maduro was able to consolidate his authority, it is unclear if such measures would have prevented Venezuela from being anywhere other than where it is today. Further, U.S. diplomatic efforts, while unsuccessful in pressuring the government to negotiate in earnest with the opposition, successfully dispelled any doubt among the region's governments regarding the intransigence of the regime, as well as highlighted the many abuses perpetrated. U.S. diplomats also believed that UNASUR would struggle to broker an agreement between the government and the opposition, which would eventually force the matter to the OAS, where the United States, Mexico, and Canada would have more traction to marshal region-wide pressure on the Venezuelan government. Had the United States attempted to block UNASUR or taken a hardline approach to Maduro early on, it would have likely prevented the growing regional consensus against Maduro and the regime's tactics.

Soon after assuming office, the Trump Administration escalated pressure on the Venezuelan government through individual and broad economic sanctions. The Department of Treasury Office of Foreign Assets Control's (OFAC's) designation in February 2017 of Vice President Tareck El Aissami as a drug kingpin sent ripples through the Venezuelan kleptocracy and served as a preview for things to come. ${ }^{36}$ In July 2017, OFAC designated 13 current and former Venezuelan government officials, including then-Foreign Minister Elías José, National Electoral Council President Tibisay Lucena, and PDVSA Vice President Simon Zerpa to try to prevent the government from moving forward with the rigged election for a Constituent Assembly to re-write the Venezuelan constitution. The Administration also went on to sanction Maduro, his wife Cilia Flores, and Executive Vice President Delcy Rodriguez. As it imposed sanctions, the White House and State Department also issued statements in defense of human rights, and U.S. Vice President Mike Pence engaged in personal shuttle diplomacy, traveling multiple times to the region before and after the August 2017 formation of the Lima Group of countries that are leading the regional response to Venezuela. ${ }^{37}$

The set of broader economic sanctions prohibited U.S. persons from trading in Venezuelan sovereign debt either on primary or secondary markets, as well as blocking PDVSA's U.S. entity CITGO from sending dividends back to PDVSA or the government. The approach was not particularly painful for U.S. companies but it did prevent Venezuela from securing additional capital on debt markets. The White House is said to be considering sectoral sanctions against the Venezuelan oil industry but has not moved forward, perhaps due to the negative impact such sanctions would have on U.S. companies.

Of late, there has also been a growing chorus in favor of military intervention in Venezuela by respected Venezuelan academics in the United States, U.S. Senator Marco Rubio, and the President of the United States. ${ }^{38}$ On September 8, The New York Times reported that Trump Administration officials discussed coup plans with rebel Venezuelan officers. ${ }^{39}$ To date, U.S. talk of intervention has not included the outlining of a strategy on how (if at all) the United States would build an international coalition or secure international and domestic legal justification, without which the United States risks fracturing the regional consensus that has been effective at marginalizing the Venezuelan regime. It is also unclear whether the Administration has considered the second and third order effects of such an undertaking, including the potential for a protracted internal conflict that galvanizes regional opposition, or pulls the United States into asymmetric warfare with colectivos and battle-hardened elements of the FARC that refused to demobilize after the 2016 peace accord with the Colombian government. ${ }^{40}$ 


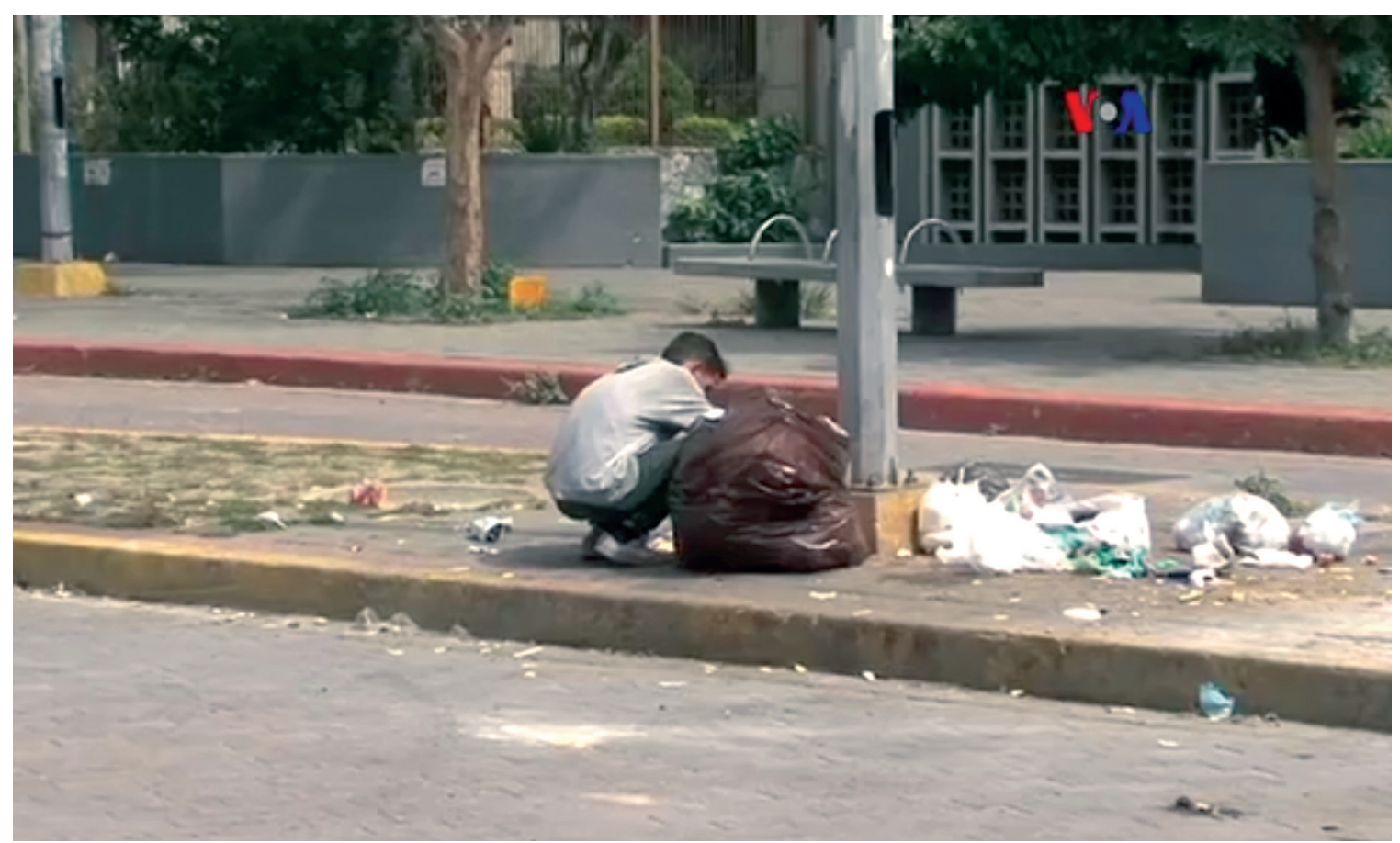

A Venezuelan eating from a garbage bag due to food shortages in 2017. (VOA)

\section{Will There be a Day Zero?}

What then? The Venezuelan regime has demonstrated a surprising level of resilience in the face of state failure and increased pressure from the international community. In a possible end game scenario, it is unclear whether Maduro would be fully empowered to negotiate. Of those who surround him-opportunists, loyalists, kleptocrats, and ideologues-it is the ideologues who are the most dangerous, because they are committed to continued entrenchment and repression as the means to remaking the country's economic model. Even if the opposition were to assume power tomorrow, armed paramilitaries and the lack of viable institutions have rendered Venezuela nearly ungovernable. Those predicting the imminent collapse of the Venezuelan regime may not have gleaned the proper message from the statue of Allende's glasses. The ideologues seem ready to die to maintain the status quo for as long as necessary.
On January 15, opposition-controlled National Assembly, led by Juan Guaido, approved a series of resolutions aimed at establishing a legal basis for removing the de facto government led by Nicolas Maduro. The opposition maintains that the constitutional order was broken after Maduro assumed office for a second six-year term on January 10, despite the fact that the May 2018 presidential election has not been recognized as legitimate by the opposition and most of the international community. The legislative measures aim to provide guarantees for the restoration of democracy by declaring Maduro illegitimate; the establishment of a transitional government led by Guaido as interim president; and the staging of a new free, fair, and transparent general election. Contrary to some criticisms by governments of the left, this was a Venezuelan-led effort by an opposition demonstrating clear unity for the first time since Maduro assumed office in 2013.

The National Assembly also moved to transfer "all political and economic powers from the 
executive power to the legislative power," including the protection of the state's assets, so that these "can be used to address [Venezuela's] complex humanitarian emergency." The National Assembly also approved a law granting amnesty from prosecution to any public official or member of the military that "collaborates with the restitution of the constitutional order." The text of the bill was distributed to all military barracks with a call on the armed forces to disobey Maduro.

The National Assembly's actions were immediately backed by OAS Secretary General Luis Almagro and the United States. To date, in addition to the United States, Argentina, Brazil, Canada, Colombia, Costa Rica, Ecuador, Panama, and Peru-core members of the 14-country Lima Group that has led regional efforts to pressure the Vezeulan government-have publicly recognized Guaido as interim president. Mexican President Andrés Manuel López Obrador continues to recognize Maduro and called for a negotiated solution to Venezuela's 'difficulties.' The EU issued an ultimatum, threatening to recognize Guaido if Maduro did not call for elections, but the list of countries outside the region recognizing the legitimacy of Guaido and the National Assembly continues to grow. In the past, the Maduro government has been able to seize upon dialogue as a way to retain power and wait for the energy of the opposition movement to fade, but this time might be different, given the overwhelming response by the United States and the international community.

As the standoff continues, there is diplomatic and economic pressure on the part of the international community, and the main focus should be first and foremost on addressing the humanitarian crisis and on imposing increased pressure on the regime. In late August, Colombia, Peru, Ecuador and Brazil made a request to the United Nations and the Red Cross to increase support for the region, and leaders from 14 countries and 10 international organizations pledged cooperation at a meeting in Quito in early September. Such a wholesome response by the countries of the region to the situation in Venezuela is relatively new and should be encouraged, but more can be done before turning to more drastic measures, like an oil embargo.

The United States has a robust sanctions regime in place, which the Lima Group should seek to mirror, and pressure the European Union to do the same. It can also play an important leadership role in addressing Venezuela's debt crisis by convening a donors conference with China, the United States, the Paris Club Secretary General, and the IMF to begin negotiations that would allow the government to enter into an adjusted repayment schedule supportable by the country's finances. Such a move would provide further signals to the Venezuelan people that the international community will help Venezuela rebuild.

Venezuela's default has provided the government a temporary boost to import food and medicine with limited consequences, given that international markets have already been closed off, so now is the time for the government to start the conversation. Latin America's history with debt crises suggests that a renegotiation with the participation of multilateral lending institutions offers the best outcome of the debt crisis for both the government and its creditors. ${ }^{41}$ Unless China and Russia plan to continue bankrolling Venezuela indefinitely, the government will eventually have to take a serious approach to renegotiating its debt. Even if oil prices were to reach $\$ 150$, as Bernestein Research recently suggested, it may not be sufficient to resolve the country's political and economic crisis. ${ }^{42}$

Negotiations would likely drag on for years, given the billions Venezuela owes in international arbitration awards and the lack of collective action clauses on PDVSA bonds. Creditors may also see losses due to delays in principal payments or a restructured agreement, but a negotiated solution would produce a higher recovery rate than efforts to seize Venezuelan assets. A successful renegotiation 
would allow Venezuela to eventually regain access to international capital markets, reinvest in its oil sector, and address shortages of food and medicine. Parallel to debt negotiations, the Lima Group should organize a donors conference to help address Venezuela's immediate humanitarian needs.

There are also five steps the United States should take to bolster its response to the Venezuelan crisis. First, it should maintain humanitarian intervention as an option, no matter how controversial, but with Responsibility to Protect (R2P) principals as the blueprint. The basic principle of $\mathrm{R} 2 \mathrm{P}$ is that:

where a population is suffering serious harm, as a result of internal war, insurgency, repression, or state failure, and the state in question is unwilling or unable to halt or avert it, the principle of non-intervention yields to the international responsibility to protect. ${ }^{43}$

R2P principles provide for diplomatic, humanitarian, and military intervention, as well as the responsibility of the international community in rebuilding and supporting reconciliation. Notwithstanding the likely opposition from China and Russia, the United States should initiate a discussion at the United Nations Security Council or have the UN Secretary General raise it under Article 99 of the UN Charter. Any discussion of intervention should prioritize the delivery of humanitarian assistance to the Venezuelan people as the first course of action.

Second, the Trump Administration should significantly increase its efforts to address the Venezuelan refugee crisis, which could cost the international community up to $\$ 5.2$ billion by some estimates. ${ }^{44}$ To date, the United States has pledged just over $\$ 95$ million to the UN Refugee Agency, the United Nations Children's Fund, the International Organization forn Migration, and the UN World Food Program, as well as \$23.5 million to help Colombia manage the influx of migrants. ${ }^{45}$
The United States can and should do more, especially in support of a key ally like Colombia. The Administration should also immediately halt the deportation of Venezuelan migrants back to their native country and grant Temporary Protected Status to Venezuelans. ${ }^{46}$

Third, it is time for the Departments of State and Treasury to target the family members of the regime and other boliburgueses, benefiting from the pillaging of Venezuela's coffers. Standard practice by the U.S. Government is to avoid punishing family members, but in the case of Venezuela anyone benefiting directly or indirectly from government corruption or illicit enrichment should by definition lose their visa or U.S. residency permit. The Administration can also use Global Magnitsky Act and Venezuela-specific authorities to target their U.S. dollar assets. The message should be clear: supporters of the regime cannot live, study, shop, or hide assets in the United States.

Fourth, as the United States ramps up pressure on the Venezuelan government, it should consistently outline the expectation of a peaceful outcome that requires Maduro to step down and be replaced by a transitional government comprised of representatives of the government and the opposition. All political prisoners should be released, and the country should hold free and fair elections, organized and overseen by a credible international body (i.e. not UNASUR). The United States should also articulate a long-term strategy for Venezuela that includes a plan for identifying and recuperating stolen assets, as well as a clear commitment to help with rebuilding.

Lastly, and perhaps most importantly, the United States needs to include Venezuela on its agenda with China, perhaps as part of U.S.-China trade talks where the Trump Administration retains significant leverage. Finding common cause with the Chinese would be the fastest and most effective way to arrive at a negotiated resolution of the Venezuelan crisis.

The situation in Venezuela is deeply worrisome, and the countries of the hemisphere have an 
important responsibility to the Venezuelan people. It is also in the national interest of the United States for Venezuela to prosper as a nation, while seeking to pursue policies supported by its people through a stable and fair democratic process. There is a serious lack of meaningful and productive dialogue between the Venezuelan government and its own people at a time when the country's economy is in crisis. Thus far, it has instead tried to distract its people and the international community from the catastrophic failure of its political and economic policies by blaming the opposition for its troubles and concocting outlandish conspiracy theories about the United States. Apologists for the regime are dwindling and there is a growing chorus pushing for a resolution to the crisis.

The United States can and should lead, but it should follow the lead of the Venezuelan opposition, and avoid reverting to the Cold War-era unilateral action that until recently defined much of our foreign policy toward the region. Such an approach will not usher Venezuela back to its place as one of the most economically and politically consequential countries in Latin America. At least that is what Allende's glasses seem to say. PRISM

\section{Notes}

${ }^{1}$ Michael Reid, The Battle for Latin America's Soul. Yale University Press, 2007.

${ }^{2}$ Max G. Manwaring, "Venezuela as an Exporter of 4th Generation Warfare Instability," U.S. Army War College Strategic Studies Institute Monograph, December 2012, available at <http://www.StrategicStudiesInstitute. army.mil/>.

${ }^{3}$ Iselin Asedotter Stronen, "A Civilian-Military Alliance: The Venezuelan Armed Forces before and during the Chavez Era," CMI Working Paper No. 4 (May 2016), available at <www.cmi.no/publications $>$; Alex Bellos, "Chavez Rises from Very Peculiar Coup," The Guardian, available at <https://www.theguardian.com/ world/2002/apr/15/venezuela.alexbellos $>$.

${ }^{4}$ Frank O. Mora, "Don't Focus on Regime Change in Venezuela," ForeignPolicy,September 4, 2018, available at <https://foreignpolicy.com/2018/09/04/after-maduro-in-venezuela-regime-change/>; Brian Fonseca,
John Polga-Hecimovich, and Harold A. Trinkunas, "Venezuelan Military Culture," Florida International University Steven J. Green School of International \& Public Affairs, May 2016.

${ }^{5}$ Fabiola Sanchez Venezuela's Maduro Seeks To Expand Armed Civilian Militias, available at <https:// apnews.com/3d7e3155411448a491d92540a910a2e2>.

6 "The Devolution of State Power: The 'Colectivos',' InSight Crime, May 18, 2018, available at <https://www.insightcrime.org/investigations/ devolution-state-power-colectivos/ $>$.

7 "Los 5 Colectivos Chavistas Más Temidos Por La Población Civil De Venezuela," Infobae. April 29, 2017, available at <https://www.infobae.com/ america/venezuela/2017/04/29/los-5-colectivos-chavistas-mas-temidos-por-la-poblacion-civil-de-venezuela/>.

${ }^{8}$ Maria C. Werlau, "Venezuela's Criminal Gangs:

Warriors of Cultural Revolution," World Affairs Journal, July/August 2014.

${ }^{9}$ Venezuelan Investigative Unit, "Drug Trafficking Within the Venezuelan Regime: The 'Cartel of the Suns','” InSight Crime, May 17, 2017, available at <https://www.insightcrime.org/investigations/ drug-trafficking-venezuelan-regime-cartel-of-the-sun/>.

${ }^{10}$ Venezuela as a Narco State., peformedby Hon. William R. Brownfield. October 12, 2018,available at $<$ https://www.csis.org/events/venezuela-narco-state>.

${ }^{11}$ Douglas Farah, "Convergence in Criminalized States: The New Paradigm,"Beyond Convergence: World Without Order (Washington D.C.: National Defense University Center for Complex Operations, 2016),179.-94, available at <http://cco.ndu.edu/News/ Article/980815/8-convergence-in-criminalized-statesthe-new-paradigm/>.

${ }^{12}$ Karina Martin, "Despite Government Obstacles, Over a Million Venezuelans March on Caracas," Panam Post, September 4, 2016, available at $<$ https://panampost.com/karina-martin/2016/09/01/ despite-government-obstacles-over-a-million-venezuelans-march-on-caracas/?cn-reloaded $=1>$.

${ }^{13}$ Organization of American States, "Message from OAS Secretary General on Elections in Venezuela," news release, May 21, 2018, availabla at <http://www.oas.org/ en/media_center/press_release.asp?sCodigo=S-019/18 $>$.

${ }^{14}$ Victor Bulmert-Thomas, The Economic History of Latin America Since Independence, 2nd ed. (New York, NY: Cambridge University Press, 2003).

${ }^{15}$ A.Doraisami, "Has Malaysia Really Escaped the Resource Curse?” Resources Policy 45, 98 (2015, April 21). Has Malaysia really escaped the resource curse? A closer look at the political economy of oil revenue management and expenditures. Resources Policy, 45, 98-108. <http:// 
dx.doi.org/10.1016/j.resourpol.2015.03.008>.

16 "Venezuela," OPEC : Venezuela. Accessed

September 10, 2018, available at <https://www.opec.org/ opec_web/en/about_us/171.htm $>$.

${ }^{17}$ Javier Corrales-Michael Penfold-Becerra, Dragon

in the Tropics: Hugo Chavez and the Political Economy Of Revolution in Venezuela (Washington, D.C.: Brookings Institution Press, 2011).

${ }^{18}$ The Guardian, "How Did Venezuela Change Under Hugo Chávez?” The Data Blog, October 4, 2012, available at <https://www.theguardian.com/news/datablog/2012/ oct/04/venezuela-hugo-chavez-election-data $>$.

19 Alexei Barrionuevo, "Cash-stuffed Suitcase Splits Venezuela and Argentina," The New York Times, August 14, 2007, available at <https://www.nytimes.com/2007/08/14/world/ americas/14argentina.html?em\&ex=1187236800\&en=a3d420 c29462728f\&ei $=5087 \% 0 \mathrm{~A}>$.

20 "How Chávez and Maduro Have

Impoverished Venezuela," The Economist, April 6, 2017, available at <https://www.economist.com/finance-and-economics/2017/04/06/ how-chavez-and-maduro-have-impoverished-venezuela?fsrc $=\mathrm{scn} / \mathrm{fb} / \mathrm{te} / \mathrm{bl} / \mathrm{ed} />$.

21 "FOCUS: Declining Oil Production: Venezuela Battles to Find a Solution," Oil and Energy Trends, 38 no. 6 (June 2013), 3-6.

${ }^{22}$ Haley Zaremba, "Venezuela: The Brutal Consequences Of Oil Addiction," May 22, 2017, available at <https://oilprice.com/Energy/Crude-Oil/VenezuelaThe-Brutal-Consequences-Of-Oil-Addiction14123.html>.

${ }^{23}$ https://tradingeconomics.com/commodity/ brent-crude-oil

${ }^{24}$ Kate Rooney, "Venezuela Is Pegging Its Economic Recovery to a Cryptocurrency That's Widely Considered a Scam," CNBC, August 20, 2018, available at <https://www.cnbc.com/2018/08/20/ venezuela-is-pegging-its-economic-recovery-to-a-cryptocurrency--thats-widely-considered-a-scam.html>.

${ }^{25}$ Nicholas Casey, "Dying Infants and No Medicine: Inside Venezuela's Failing Hospitals," The New York Times, May 16, 2015, available at <https:// www.nytimes.com/2016/05/16/world/americas/ dying-infants-and-no-medicine-inside-venezuelas-failing-hospitals.html>; Robert Rapier, "Venezuela's Oil Exports Are Headed Toward Zero," Forbes, June 8, 2018, available at <- https://www.forbes.com/sites/ rrapier/2018/06/08/venezuelas-oil-exports-are-headed-toward-zero/\#4c8a96aa6876>.

${ }^{26}$ Daniela Galarza, "Salt Bae Proudly Feeds Venezuelan Leader \$275 Steak While Venezuelans Starve," EATER.com. September 18, 2018, available at <https://www.eater.com/2018/9/18/17873692/salt-bae-venezuela-leader-nicolas-maduro-venezuelans-starve $>$.

${ }^{27}$ Eyanir Chinea and Corina Pons, "Venezuela Ex-ministers Seek Probe Into \$300 Billion in Lost Oil Revenue," Reuters, February 2, 2016, available at $<$ https://www.reuters.com/article/us-venezuela-politics-idUSKCNOVB26F>; and Financial Crimes Enforcement Network, "Fincen Names Banca Privada D’andorra a Foreign Financial Institution Of Primary Money Laundering Concern," news release, March 10, 2015, available at <https://www.fincen.gov/news/ news-releases/fincen-names-banca-privada-dandorra-foreign-financial-institution-primary-money $>$.

${ }^{28}$ Jay Weaver, and Antonio Maria Delgado, "Ring Plundered \$1.2 Billion of Venezuelan Oil Money, Laundered It in South Florida, Feds Charge," Miami Herald, July 25, 2018, available at <https://www.miamiherald.com/latest-news/article215493015.html $>$.

${ }^{29}$ This calculation does not include PDVSA's debt, which is significant; see Patricia Laya, Jose Enrique Arrioja, and Fabiola Zerpa, "Venezuela's 30 Minutes of Debt Talks Leave Bondholders Guessing," Bloomberg, November 13, 2017, available at <https://www.bloomberg. com/news/articles/2017-11-13/venezuela-s-30-minutes-ofdebt-talks-leave-bondholders-guessing $>$.

${ }^{30}$ Ben Bartenstein, Ben, Fabiola Zerpa, Andrew Rosati, and Aline Oyamada, "China to Lend Venezuela \$5 Billion as Maduro Visits Beijing," Bloomberg, September 13, 2018, available at <https://www.bloomberg.com/ news/articles/2018-09-13/china-to-give-venezuela-5-billion-loan-as-maduro-visits-beijing >; see also Kevin P.Gallagher and Margaret Myers, "China-Latin America Finance Database," Washington: Inter-American Dialogue, accessible at <https://www.thedialogue.org/ map_list/>.

31 "China Approves US\$5Bn Loan for Venezuelan Oil Development,” Venezuelanalysis.com, July 5, 2018, available at <https://venezuelanalysis.com/news/13918>; see also "China Approves Us $\$ 5$ bn Loan For Venezuelan Oil DevelopmentTeleSur English, July 5, 2018, availanle at <https://venezuelanalysis.com/news/13918>.

${ }^{32}$ Henry Fow, John Paul Rathbone, and

Kate Allen, "Russia and Venezuela Agree \$3bn Debt Restructurin,." Financial Times, November 15, 2017, available at <https://www.ft.com/ content/5f3084c6-ca03-11e7-ab18-7a9fb7d6163e>.

${ }^{33}$ Ed Vulliamy, "Venezuela Coup Linked to Bush Team," The Guardian, April 21, 2002, available at <https://www.theguardian.com/world/2002/apr/21/usa. venezuela $>$.

${ }^{34}$ Julian Borger, "Brazilian President: US Surveillance a 'breach of International Law', The 
Guardian, September 24, 2013, available at <https:// www.theguardian.com/world/2013/sep/24/

brazil-president-un-speech-nsa-surveillance $>$.

${ }^{35}$ Executive Office of the President, Exec. Order No. 13692 of March 8, 2015 on "Blocking Blocking Property and Suspending Entry of Certain Persons Contributing to the Situation in Venezuela," available at $<$ https:// www.treasury.gov/resource-center/sanctions/Programs/ Documents/13692.pdf>.

${ }^{36}$ U.S. Department Of the Treasury, "Treasury Sanctions Prominent Venezuelan Drug Trafficker Tareck el Aissami and His Primary Frontman Samark Lopez Bello," February 13, 2017, available at $<$ https://www.treasury.gov/press-center/press-releases/Pages/as0005.aspx $>$.

${ }^{37}$ The original Lima Group countries were Argentina, Brazil, Canada, Chile, Colombia, Costa Rica, Guatemala, Honduras, Mexico, Panama, Paraguay and Peru. Guyana and Saint Lucia joined later.

${ }^{38}$ Ricardo Hausmann, "D-Day Venezuela," Project Syndicate, January 2, 2018, available at $<$ https://www.project-syndicate.org/commentary/ venezuela-catastrophe-military-intervention-by-ricardo-hausmann-2018-01?barrier=accesspaylog >; Ramsey Touchberry, "Marco Rubio: U.S. Military Intervention Could Solve Venezuelan Crisis," Newsweek, September 1,2018 , available at $<$ https://www.newsweek.com/marco-rubio-us-military-solution-venezuela-1101123>; Joshua Goodman, "Trump Pressed Aides on Venezuela Invasion, U.S. Official Says," Bloomberg, July 4, 2018, available at $<$ https://www.bloomberg.com/news/articles/2018-07-04/us-official-trump-pressed-aides-about -venezuela-invasion $>$.

${ }^{39}$ Ernesto Londono and Nicholas Casey,"Trump Administration Discussed Coup Plans With Rebel Venezuelan Officers," The New York Times, September 8, 2018, available at $<$ https://www.nytimes.com/2018/09/08/ world/americas/donald-trump-venezuela-military-coup. html>.

${ }^{40}$ Shannon K. O’Neil, “A U.S. Military Intervention in Venezuela Would Be a Disaster," Bloomberg, September 17, 2018, available at <https://www.bloomberg.com/view/ articles/2018-09-17/a-u-s-military-intervention-in-venezuela-would-be-a-disaster>.

${ }^{41}$ Bianca De Paoli, Glenn Hoggarth, and Victoria Saporta,"Costs of Sovereign Default," Financial Stability Paper no. 1, Bank of England, July 2006.

${ }^{42}$ Tom DiChristopher, "Big Oil Is Sowing the Seeds for a 'super-spike' in Crude Prices above \$150, Bernstein Warns," CNBC, July 6, 2018, available at <https://www. cnbc.com/2018/07/06/big-oil-sowing-the-seeds-forcrude-prices-above-150-bernstein-warns.html>.

${ }^{43}$ The Responsibility to Protect: Report of the
International Commission on Intervention and State Sovereignty. December 2001, available at $<\mathrm{http}$ ://responsibilitytoprotect.org/ICISS Report.pdf>.

${ }^{44}$ Dany Bahar and Sebastian Strauss,"Neighbor Nations Can't Bear Costs of Venezuelan Refugee Crisis Alone," The Hill, Accessed March 7, 2018, available at $<$ https://thehill.com/opinion/international/377186-neighbor-nations-cant-bare-costs-of-venezuela-crisis-alone $>$.

${ }^{45}$ U.S. Department of State, "United States Continues To Assist Venezuelans in Need," news release, September 25, 2018, available at $<$ https://www.state.gov/r/pa/prs/ ps/2018/09/286203.htm>.

${ }^{46}$ Franco Ordonez, "Trump Administration Deports Venezuelans While Pledging Aid," McClatchy, April 24, 2018, available at <https://www.mcclatchydc.com/news/ nation-world/world/article209726344.html>.

\section{Photos}

Page 40. Reproduced with permission from Moises Rendon, Associate Director and Associate Fellow, Americas Program at the Center for Strategic and International Studies.

Page 48. Licensed under Creative Commons Attribution-ShareAlike 4.0 International License. Photo produced unaltered.

Page 50. Photo taken from a public domain Voice of America video and posted to Wikimedia by ZiaLater, using UploadWizard. 


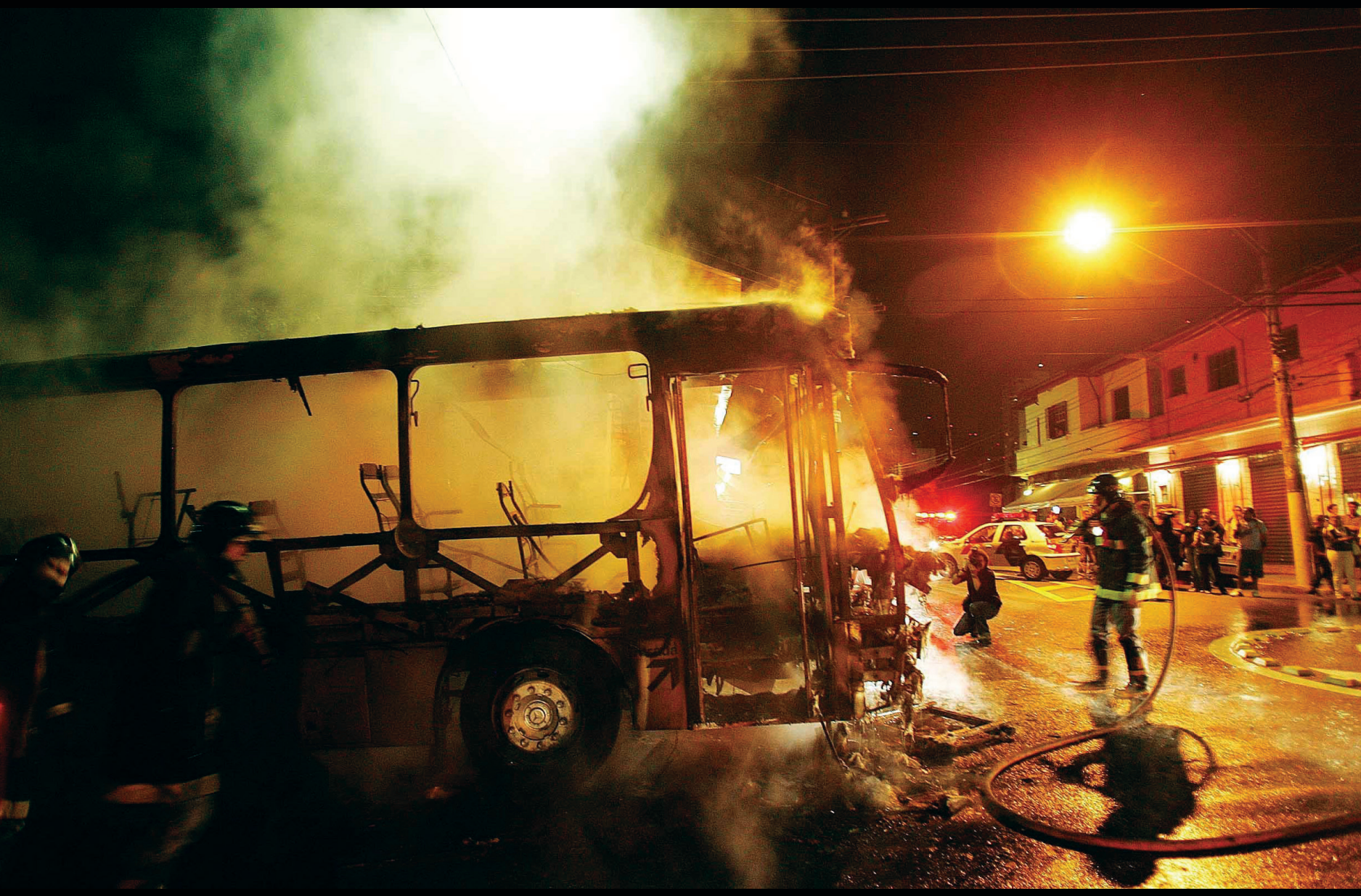

Firefighters fighting a fire in one of the 90 buses destroyed in a series of attacks coordinated by the PCC in São Paulo in May 2006. (Folhapress/ Rogério Cassimiro/) 


\section{The Evolution of the Most Lethal Criminal Organization in Brazil-the PCC}

By Leonardo Coutinho

$\mathrm{B}$ razil is the country of soccer. This statement is significant as a reference to one of the elements of Brazilian national and sub-group identity formation, and as a catalyst of social cohesion. ${ }^{1}$ The national sport of Brazil is also, not surprisingly, the favorite of Brazilian prisoners. In each of Brazil's 1,496 prisons there is a soccer field - whether designed specifically for this purpose or simply improvised in areas intended for sunbathing inmates. ${ }^{2}$ In the early 1990s, there were only eight inmates from the state capital in the Taubaté prison in São Paulo. ${ }^{3}$ Surrounded by inmates transferred from the various hinterland areas around São Paolo who considered them arrogant, the eight capital city thugs joined in a mutual protection pact within the prison. This was the origin of the "Capitals" gang.

The Capitals formed a soccer team that competed against other teams in the prison. On August 31, 1993 the Capital prisoners held a self-organized championship soccer tournament, appearing at the first game wearing standard white T-shirts; scrawled in blue ballpoint pen ink on the left breast were three letters-PCC, referring to Primeiro Comando da Capital, or First Capital Command. After the tournament the PCC assassinated the most feared criminals in Taubaté prison, earning the respect and loyalty of their fellow inmates and establishing themselves as the new prison bosses. ${ }^{4}$

In 1993 Brazil's prisons were still reeling from what had until then been the biggest ever outbreak of prison violence. Less than a year earlier, 111 inmates were shot dead by police in an operation to stem a rebellion in the Carandiru prison in São Paulo city. The tragedy began as a banal fight between two rival gangs for possession of a few boxes of cigarettes. ${ }^{5}$ In 1993, as they assumed the dominant position within the prison gang hierarchy, the PCC adopted the discourse of unity, arguing that in the previous year's carnage the prisoners themselves were to blame as they were fratricidal and ungoverned by an organization strong enough to keep the peace amongst them and represent them both inside and outside the prisons. An inmates' charter was drafted and the criminals pledged to the motto, "Brother does not kill brother. Brother does not exploit brother. The 'Founders' are the leaders."'

The PCC operational foundation was based on two pillars. Internally, PCC inmates would submit to a new rule, behaving in a more coordinated but less confrontational fashion, protecting their own, but still

Brazilian journalist Mr. Leonardo Coutinho is a former editor and foreign correspondent in Washington, D.C. for Brazilian magazine VEJA (2000-18). Translated from Portuguese by Michael Rodelo. 
liquidating their rivals. Externally, the PCC would provide unified legal assistance, supported by the monthly contributions from each of the incarcerated members, who were required to make payments to the organization through their family members. Inspired by, and organizing along, the trade union model, the PCC attracted an ever-increasing number of members. And its modernizing message, which transcended the message of a conventional gang, was exported to several other prisons by transferred PCC members. By 1995, the PCC would win control within the Carandiru penitentiary, which was at the time the largest prison in Latin America.

\section{The Second Phase}

In the beginning PCC financial revenues were not exclusively the product of crime. As noted, each PCC member paid a monthly fee to the organization's funds supply, even while they engaged independently in various forms of criminal activity. While conventional prison gangs used violence to recruit and control, PCC resorted to such violence only in exceptional situations. Older criminal organizations, such as the Comando Vermelho (Red Command or CV), centered their business models on drug trafficking, while the PCC was trying to establish itself as a "self-help society."

In 1999, a bank robber named Marcos Williams Herbas Camacho, known by the nickname Marcola, joined the PCC leadership. Of Bolivian descent Marcola, who was considered a genius among criminals, imposed a new dimension on the organization's business model. By that time PCC not only dominated more than two dozen prisons, it also controlled thousands of members free on the streets. The emerging PCC leader understood that at-large members were a precious asset to the organization, useful for increasing revenue, influence, and power. Under Marcola's management, the PCC began its consolidation as what Max Manwaring called a "second generation gang," organized as much for business as for control of the local terrain. ${ }^{8}$ Marcola not only expanded PCC activity in drug trafficking and bank robbery (the latter his specialty), he also led the organization to adopt a market view of crime and to conquer market share by way of violence, sweeping away competitors.

The PCC grew in obscurity thanks to the Brazilian government's denial of its existence. Within the public security structure PCC was not considered a serious threat. It was only in 1996 that a deputy from the State of São Paulo became the first Brazilian authority to publicly refer to the organization. PCC was first mentioned in the Brazilian press only a year later, but still no one took them seriously. The PCC, according to the governor of São Paulo, was "a fiction." The government's strategy to dismantle PCC was to deny its existence and separate its leaders by transferring them to prisons in other cities and states.

That policy of separation failed. By sending "graduate" members of the PCC to other parts of the country, the government unwittingly helped the PCC to expand its domain throughout Brazil. These transferred inmates served as "ambassadors" of the organization wherever they went. Many were from the largest and richest of the Brazilian states and came with experience in organizational innovation which greatly exceeded the local gangs. They represented an organization that was able to provide protection beyond the prison walls and São Paulo state borders. To reinforce this dynamic, PCC itself started riots, thereby provoking the state to react by sending members to other prisons throughout Brazil. ${ }^{9}$

In February 2001, the PCC seized the Brazilian public's attention when 28,000 inmates took control of 29 prisons in nineteen cities in the state of São Paulo. ${ }^{10}$ The mega-riot took place on a Sunday, during visiting time. No less than 10,000 people were taken hostage. Sheets painted with the PCC insignia were hung on the windows. In 
Figure 1: Brazil's prison crisis.

Prisoners (in thou) Prison capacity (in thou)

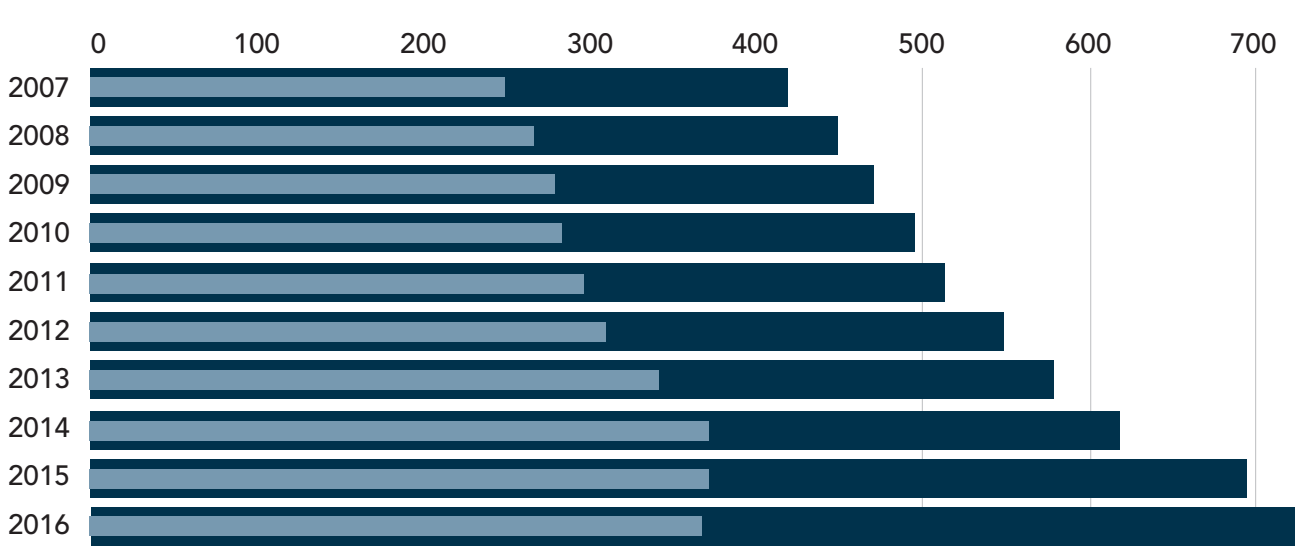

*2016 data: January-June

Source: The Brazil Report, "Brazil's Prison Crisis." Reproduced unaltered with permission from The Brazil Report; data from Brazil's Ministry of Justice.

Carandiru—the very prison where 111 people had been killed in a conflict with police a decade before-the PCC held 5,000 hostages. Twenty-seven hours later, the hostages would be freed and the riot controlled, but the PCC's relationship with the state would never be the same.

\section{Insurgency as a Political Instrument}

Having demonstrated its capacity for mobilization and upon realizing the impact caused by what would be considered the biggest riot in Brazil's history, PCC leaders were convinced of their ability to confront, embarrass, and blackmail the state. The organization's debut proved so successful that the PCC began to call itself the "Party of Crime." Soon after this first collective action, and less than a decade after its establishment, the PCC adopted an action plan that would define it as a "third-generation gang" with a political agenda and transnational connections.

Another critical milestone in the evolution of the PCC was the 2002 arrest and incarceration in Brazil of Chilean terrorist Mauricio Hernández Norambuena. Norambuena was a member of the
Patriotic Front Manuel Rodríguez (FPMR) and had master-minded the kidnapping of a Brazilian businessman. ${ }^{11}$ A fugitive from Chilean justice since 1996, Norambuena, known as "Commander Ramiro," was the operational leader of FPMR. In his own country, he had twice been sentenced to life imprisonment for the murder of a senator and kidnapping of a businessman. Considered the second in the FPMR hierarchy, Norambuena coordinated numerous bombings and kidnappings. Investigations in Brazil revealed that Norambuena received training and the rank of Colonel from the Cuban Army. ${ }^{12}$ This militant from the armed left, highly proficient in insurgency actions, was imprisoned in a cell with Marcola.

\section{According to Attorney Marcio Sérgio} Christino-one of the first authorities to act in the fight against the PCC-the Marcola-Norambuena partnership marked a new phase for the organization. The cerebral Marcola became a student of Norambuena. He learned the concepts of asymmetric warfare and urban guerrilla warfare, and he further developed the political program of the 
PCC, as a way of guaranteeing the perpetuation of the criminal enterprise which, at that moment, was undergoing full expansion in Brazil.

On March 7, 2002, just one month after the union of Marcola and Norambuena, the PCC attempted its first terrorist attack in São Paulo. An automobile loaded with 40 kilograms of powergel (emulsion) explosives was parked in front of the Barra Funda Forum, where 5,000 people worked and another 7,000 transited each day. Due to a device flaw, the attack failed.

Police monitoring of telephone conversations between PCC members, by means of bugged cell phones surreptitiously provided to prisoners, revealed the PCC mission orders to disrupt the upcoming São Paulo gubernatorial election. The content of the audios would only become public four years later. ${ }^{13}$ From their prison cells, the PCC leaders planned a series of incidents to discredit the incumbent governor seeking re-election. According to the audios, PCC had chosen the leftist opposition Workers Party (PT) candidate and would work towards his election. On the eve of the first round of elections, the PCC leadership issued an order that all family members of the prisoners vote for their candidate. To ensure greater participation in the polls, the organization

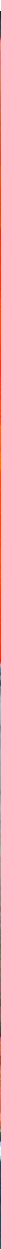

Police forces prepare for the invasion of a detention unit of juvenile offenders under the command of the PCC, in São Paulo. The teenagers rebelled under the coordination of the faction that recruits its members from youth. (Folhapress/ Fernando Donasci/) 
determined that there would be no family visits on election day in order to maximize turnout.

The PCC's electoral effort appears to have succeeded. The faction's preferred candidate managed to reach the second round of the 2002 election for the São Paulo governorship. As the campaign progressed to the next stage, Marcola and the PCC top leadership made the drastic decision to attack Brazil's economy by blowing up the São Paulo stock exchange. The impact of this they believed would favor the leftist candidate, and could also change the course of the presidential election later that year. According to experts who followed the evolution of the PCC, it was the guerrilla mind of Norambuena that brought PCC to the terrorism toolbox. Fortunately the attack was disrupted when police wiretapping led to discovery of a car loaded with 66 pounds of explosives just six days before the second round of elections. For more than a year and a half, Marcola and Norambuena continued to share ideas inside Taubaté prison. Treated as a brother by faction members, Norambuena gained leadership status. ${ }^{14}$

In 2006-a year in which it was believed that President Luiz Inácio Lula da Silva (PT) would not be reelected due to an investigation of his government's involvement in what was known as the Mensalão scandal-the PCC attacked again. ${ }^{15}$ The single "grand attack" strategy that had failed twice was replaced by a series of actions comprising a massive wave of PCC violence. During a nine-day period, the PPC conducted 293 attacks on police stations and public buildings. Dozens of buses were set on fire and São Paulo-the largest city in Latin America-was paralyzed by the wave of terror.

The PCC eventually signed a truce when the São Paulo government agreed to secret negotiations. ${ }^{16}$ The complete terms of the agreement were never disclosed, but after Marcola received a high-level government delegation in the prison, he ordered his followers to abort the operation. Marcola got what he wanted - the state entered into a direct dialogue with the PCC. To "reward" the government for this dialogue, the PCC established a truce that, according to some experts on violence in Brazil, had direct implications on the profile of violence in São Paulo state and later in other regions of the country. The main Brazilian cities were experiencing a homicide boom; São Paolo being one of the most violent in the world had homicide rates that reached 66 per 100,000 inhabitants. ${ }^{17}$ After the truce between PCC and the government, the number of deaths in the state of São Paulo began declining to the extent that by 2016 , the homicide rate was 46 percent lower. ${ }^{18}$ One of the pioneering studies of the PCC's impact on the homicide rate concluded that the faction had become a "monopolist" of death. ${ }^{19}$ Crimes previously uncontrolled came under the management of the PCC leaders. ${ }^{20}$ The PCC began to determine who dies, how many die, and when they die. Marcola successfully exported this system to other parts of Brazil on the grounds that the broader society should be spared from the violence meant exclusively for PCC's enemies. ${ }^{21}$

The ability to influence or even credibly threaten the government and intervene in the daily life of Brazilian society defines PCC as what U.S. Army War College Professor Max Manwaring called a "third generation gang." 22 The evolution of the PCC suggested that the organization not only began to implement actions advancing a political and economic agenda, it also began to act as a transnational criminal organization. Nonetheless, while the PCC arguably meets the requirements of Manwaring's concept of third generation gangs, there is still debate among scholars and experts as to whether the organization has reached this level. ${ }^{23}$

By 2016 the Minister of Justice and the President of the Superior Electoral Court of Brazil believed they had found the first evidence of politics mimicking organized crime. ${ }^{24}$ Their investigation indicated that, of a total of 730,000 donations registered to the candidates and parties that contested 
that year's elections for mayors and city councilors, at least 300,000 were from people without sufficient financial means to make such contributions. Early indications were that organizations such as the PCC were behind this financial scheme. Their assessment revealed that the campaign of overt PCC attacks during previous presidential election years had been replaced by a strategy of political interference behind the scenes. The PCC had started to invest in and elect candidates within the established political process. Evidence has subsequently emerged in several parts of the country that politicians linked to organized crime actually won their elections. ${ }^{25}$ In 2018, eight of Brazil's 27 states requested federal troop reinforcements fearing armed interference by criminal factions, the most powerful of which is the PCC. ${ }^{26}$ But by that time the political action of organized crime in Brazil was no longer based in explicit violence. Criminal organizations instead have begun to play a leading role in formal political activities and disputes. ${ }^{27}$ They finance not only candidates who serve their interests, but also those who promote the political campaigns of their own members. ${ }^{28}$ In the State of Ceará, one of the main PCC bases outside of São Paulo, the local government intelligence agencies investigated ten mayors and fifty councilmen who received election support from the PCC..$^{29}$

PCC pressure and influence on the decisions of the political system eventually increased to such alarming levels that it provoked a reaction from the authorities. In April 2016 the government of the State of Ceará planned to install systems for blocking telephone communication in prisons, pending the approval of a law by the State deputies. After several riots and retaliatory protests, the PCC left a car with 29 pounds of explosives parked in front of the legislature building in the city of Fortaleza. The criminals themselves warned the police of the device, but that threat alone was sufficient to gain a postponement of the legislation for several months; and even after the law was eventually passed, the blockers were never installed in prisons.

\section{Territorial Domain and Finance}

At least 27 gangs are active in Brazil according to security and intelligence agencies. ${ }^{30}$ The PCC is the largest, with an estimated 30,000 members who exercise control over 90 percent of the prison population,or 550,000 prisoners. ${ }^{31}$ The first South American countries in which the PCC extended its dominions were Paraguay, Bolivia (where it operates almost monopolistically), Peru, and Colombia; all countries in which suppliers compete with rivals $\mathrm{CV}$, the second largest gang in Brazil. ${ }^{32}$

Following the demobilization of the FARC in Colombia, PCC began to recruit the trained labor of ex-guerrillas. ${ }^{33}$ Growing suspicions of this development within the Brazilian Ministry of Defense were confirmed in the field. Interviews with policemen revealed frequent occurrences of fighting with Colombian traffickers who were increasingly wellarmed and proficient in combat, especially in the jungle areas. There is a historical link and strategic logic to the PCC's interest in former FARC guerillas. In the 1990s, one of the most powerful Brazilian traffickers, Fernando da Costa, established a partnership with the FARC. ${ }^{34}$ Known by the nickname of Fernadinho Beira Mar, he was a member of CV. Beira Mar's involvement with the FARC became evident in 2001, when he was arrested by Colombian security forces in an operation with FARC leaders. An investigation by the Brazilian Congress found that the Colombian guerrilla group had established a joint venture with CV to obtain arms trafficked from Suriname, and to sell drugs in Brazil and in Europe. ${ }^{35}$ The collaboration with the FARC led to CV's and Beira Mar's domination of Amazonian traffic routes, whose origins were in Colombia. Despite the imprisonment of Beira Mar, the ties were maintained and the $\mathrm{CV}$ and its allied gangs, including the gang Família do Norte (The Northern 
Family or FDN), have expanded their influence and power in the Amazon region, especially in the State of Amazonas, bordering Colombia. ${ }^{36}$

To conquer the Amazon route, which was formerly dominated by rivals, the PCC resorted to "skilled labor." The Amazonas police authorities began to observe an increase in the brutality of the fighting between rival traffickers in the Amazon river region. Called "pirates," the PCC soldiers attacked drug shipments carried on FDN and CV vessels, in several cases using the AKM and FAL rifles typical of FARC guerrillas. In other cases Brazilian police officers were identified carrying military material diverted from the Colombian army. Reports by Brazilian police into this new pattern of violence appear to confirm the presence of FARC ex-combatants in the assault groups used by the PCC in the war for control of the routes from Colombia.

Also in northern Brazil, the PCC has taken advantage of the humanitarian crisis in Venezuela to recruit among the refugees who arrive through the State of Roraima. ${ }^{37}$ Venezuelans have added value to Brazilian criminals as a bridge to Bolivarian militias and arsenals provided by the Chávez-Maduro government. To the PCC the economic crisis in Venezuela makes this a cheap source of weapons which are sold for food by desperate Venezuelans. ${ }^{38}$ In addition, PCC "ambassadors" operate in Paraguay, where they participate directly in the production and shipping of marijuana, counterfeit cigarettes, weapons, and ammunition going to Brazil. In Bolivia, Brazilian criminals have become the principle clients of local cocaine producers and are nearly the exclusive distributors of Bolivian drugs within Brazil. The latest survey measuring the number of drug users in Brazil concludes that as of 2012 there were two million cocaine addicts and another one million crack addicts; figures that make Brazil one of the largest consumer markets for cocaine, behind only the United States. ${ }^{39}$ Projections by Brazilian authorities indicate that the drug

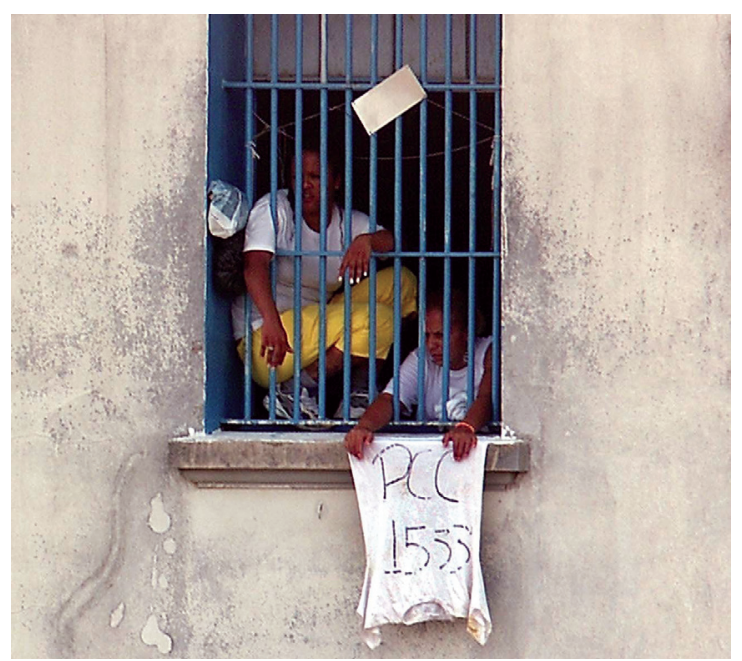

Women show "flag" of the PCC in rebellion against transferring our leaders to maximum security prisons. The gang is also identified by the number 1533, referring to the order of the letters $P(15)$ and $C(3)$ in the alphabet. (Folhapress/Cesar Rodrigues)

market is valued at as much as $\$ 8$ billion per year; with 60 percent of sales, PCC is owner of the largest market share. ${ }^{40}$

The financial power of the PCC is accompanied by its ability to control significant portions of the cities in which it operates. Territorial control is achieved by force and consolidated with money. In the states of Acre, Rondônia , Mato Grosso, and Mato Grosso do Sul in western Brazil, the PCC controls the border stretch that extends from Bolivia to Paraguay. In the state capitals the organization controls entire portions of the city. In Porto Velho, capital of Rondônia State, the PCC took over management of a condominium complex built by the Federal Government to serve 2,000 low-income families. ${ }^{41}$

The PCC has an efficient, almost military organizational structure, with leadership below Marcola distributed in layers, whose functions include management of collection, control of drug "stock," import, export, and human resources. The sector responsible for the management of affiliates has a ledger with the complete registration of each member, including both those in prison and on the streets. The upper orders follow a pyramidal path. 
The retail traffickers, who work on the street are subordinate to the managers, who in turn report to the heads of the "kitchens," or places where cocaine is mixed with other products before being sold on the streets. Although they report to the same boss, the kitchen managers do not interact with each other. In this manner they seek to compartmentalize activities in order to avoid a chain reaction if one of these structures is uncovered by the police.

As noted, the main source of PCC revenue is from drug trafficking. However, drugs are not its only criminal modality. Bank robbery remains another major source of revenue for the PCC. Brazilian criminals have developed a distinctive technique for robbery; the explosion of ATM terminals. In 2015, no fewer than 3,000 ATMs were destroyed. ${ }^{42}$ Though it is not possible to ascertain with certainty the percentage of those attributable to PCC, a conservative estimate suggests PCC is responsibile for around 50 percent. Assuming each ATM requires one to two sticks of dynamite for such attacks, the 3,000 attacks in 2015 (a rate of 8.2 per day) would have required some 3,000 to 6,000 sticks of dynamite. The source for these explosives can be traced to the illegal trade in explosives which originates in Paraguay and Bolivia, where the materials are widely used by the mining industry.

\section{The PCC War}

By 2017 Brazil had well established itself as the country with the highest number of homicides in the world. That year, 63,880 people were murdered. ${ }^{43}$ The victims were typically ordinary citizens who directly suffer the impact of the high crime rates. Advocates of drug decriminalization attribute the death toll to the "war on trafficking." However, security officials from a dozen states testify that the profile of crimes reported to the authorities follows a different predominant pattern. ${ }^{44}$ They say that most of the violent deaths recorded in Brazil are not the result of the war against drugs - that is the state against the bad guys. Most lives lost are the result of another type of war. Who else kills the criminals? It is the criminals themselves. ${ }^{45}$ Regrettably there are no official statistics informing a precise analysis of the impact of organized crime on the total record of homicides. Some of these numbers are police estimates, which in some localities reach a projected correlation of 80 percent of drug trade and consumption to the occurrence of homicides. ${ }^{46}$

The PCC emerged and grew in the dark, ignored by the authorities. Now that it is the leading criminal organization in Brazil and indeed in South America, it still benefits both from the silence of the authorities and from the lack of an approach that acknowledges PCC as a transnational criminal organization which commits crimes from north to south across the length of South America. PCC uses the banking systems of dozens of countries, including the United States, for money laundering. ${ }^{47}$ Investigations conducted by the Brazilian Federal Police have detected links between the PCC and Hezbollah in drug trafficking operations. Brazilian criminals offer protection to Lebanese agents and act as logistic operators for the Shiite militias sending drugs through Brazilian ports to Africa, Europe, and the Middle East. ${ }^{48}$ In return, the Lebanese offer money laundering and logistics networks enabling the PCC to reach drug markets already familiar to or dominated by Hezbollah, including many in Africa and the Middle East. The PCC has shown itself capable of adapting, of blackmailing the state, of functioning as a transnational crime organization (even if not formally recognized by the authorities as such), and of becoming one of the greatest threats to political stability and public security in Brazil and its neighbors.

Brazilian officials believe that ties between the PCC and Hezbollah have been strengthened by the arrest of some of the Lebanese organization's financial operators, particularly Farouk Abdul Hay Omairi, a Lebanese citizen who was designated by the U.S. Department of the Treasury for his links 
to terrorist groups. ${ }^{49}$ Omairi lives in the Brazilian city of Foz do Iguaçu and was arrested in 2006 for being the kingpin of a gang of cocaine traffickers, along with his son, Ahmad Farouk Omairi. The two were accused of leading a drug delivery network trafficking to Europe and the Middle East. Brazilian authorities had been monitoring the Omairi family and other extremists operating in the Tri-Border Area for years, but the lack of anti-terrorism legislation in Brazil prevented their arrest. Nevertheless, terrorism financing transactions are generally associated with other illegal activities, such as money laundering, smuggling, and drug trafficking, leading Federal Police to focus on these crimes.

The arrest of Omairi and his son was the genesis of a criminal-terrorist association between PCC and Hezbollah. The Omairi family was offered protection by members of the PCC while in prison-an agreement negotiated directly with Hezbollah according to an investigation by the Brazilian Federal Police. The partnership has since deepened, and now PCC and Hezbollah work jointly in drugs and arms trafficking. According to Brazil's Federal Police investigations, Hezbollah sells weapons to Brazilian criminal organizations, and has also used the PCC's criminal services inside Brazil. Hezbollah also brokered the sale of $\mathrm{C} 4$ explosives stolen in Paraguay and sold on the black market at very low prices. ${ }^{50}$

\section{Follow the Money}

After more than a decade of denying its existence, Brazilian authorities have finally recognized the PCC as a criminal organization that is a significant threat to public security, whose capacity to threaten democracy and the state can no longer be ignored. In 2018 Brazilians identified public security as one of their most important concerns, rivaling even the resumption of economic growth in a country experiencing its worst economic crisis in more than a century. ${ }^{51}$ The violence generated by Brazilian gangs became the main subject of the presidential campaign of 2018, and Jair Bolsonaro-the winning candidate-was elected on the promise of a relentless and hard fight against organized crime.

In October, just days before the end of the presidential race, the Brazilian government inaugurated what can be considered the first effective step to combat the PCC and other organized crime groups operating in Brazil. An executive order authorized the establishment of the first Brazilian intelligence task force with the sole purpose of monitoring and combating criminal organizations. The current challenge for the authorities is how to identify and dismantle the PCC's influence networks within the executive, legislative, and judiciary branches.

Recent investigations revealed that PCC criminals launder money using the same network discovered by Operation Lava Jato, which is celebrated as the largest anti-corruption investigation in Brazilian history. The investigations of the Brazilian Federal Police showed that the financial apparatus of the PCC has reached levels of professionalism that placed them among the most sophisticated laundering networks discovered in Brazil to date. An unprecedented joint effort by police, military, and state intelligence agencies will have as its basic objective to break the organization's laundering and financing networks.

Born in prison, the PCC is an organization immune to prisons. Its top leaders are already behind bars, yet they do not stop operating. The conclusion is that in addition to sending PCC to prison the financial power of the organization must be targeted. This effort will require Brazil to recognize the transnational character of the PCC, and to seek international support and cooperation. PRISM

\footnotetext{
Notes

${ }^{1}$ Jocimar Daolio, Football, Culture and Society (Campinas:Autores Associados, 2005).

${ }^{2}$ Conselho Nacional do Ministério Público, "Capacidade e Ocupação das Unidades Prisionais Brasileiras,"April 30, 2018, available at < http://www.cnmp.
} 
mp.br/portal/sistema-prisional/index.php?option=com_ content\&view $=$ article\&layout $=$ edit $\&$ id $=11176>$.

${ }^{3}$ Fátima de Souza, PCC: A Facção, (Editora Record, 2007).

${ }^{4}$ Marcio Sergio Christino and Claudio Tognolli, Laços de Sangue, a história secreta do PCC, (Matrix, 2017).

${ }^{5}$ Leonardo Coutinho, "A Origem," VEJA, October 05, 2016, available at <https://veja.abril.com.br/brasil/ carandiru-como-o-massacre-de-111-presos-levou-a-criacao-do-pcc/>.

${ }^{6}$ Christino and Tognoll, 2017.

${ }^{7}$ Comando Vermelho (CV) is a Brazilian criminal group created in 1969, during the military regime in Brazil (1964 $\neg 85)$. The CV is the result of an alliance between leftist militants and common criminals. Originally, this group's purpose was for self-protection of prisoners. But in the 1980s, CV started narcotraffic activities. CV is a most powerful enemy of PCC and command the narcos's web in Rio de Janeiro city and more other places, include de Colombian route to Brazil.

${ }^{8}$ Max G. Manwaring, "Street Gangs: The New Urban Insurgency," Strategic Studies Institute, 2005, 1-47.

${ }^{9}$ Christino and Tognoll, 2017.

${ }^{10}$ Kristhian Kaminski and Larissa Squeff, "Eles tomaram o poder," VEJA, February 22, 2001.

11 "Chilean Leftist Is Held in Brazil Kidnapping," The New York Times, February 2, 2002, available at <https:// www.nytimes.com/2002/02/05/world/chilean-leftist-isheld-in-brazil-kidnapping.html $>$.

12 "Sequestrador de Olivetto concede entrevista exclusiva ao 'Estado,"' Estado de S.Paulo, November 11, 2002, available at < https://brasil.estadao.com.br/noticias/ geral,sequestrador-de-olivetto-concede-entrevista-exclusiva-ao-estado,20020511p17200>.

${ }^{13}$ Juliana Linhares e Camila Pereira. "O PCC ataca. Mas também leva," VEJA. August 16, 2006.

14 "Hernández Norambuena enseñó 'tácticas' a grupo que convulsiona a Sao Paulo," El Mercurio, July 14, 2006, available at <https://www.emol. com/noticias/internacional/2006/07/14/225179/ hernandez-norambuena-enseno-tacticas-a-grupo-que-convulsiona-a-sao-paulo.html $>$. Of mention, in 2016 police discovered that 12 years after first contact, the PCC still sponsored the Chilean terrorist's defense, showing how important he had become to the PCC.

15 The "Mensalão" scandal, discovered in Brazil in 2005, gave rise to a commission of investigation in the Brazilian Congress to investigate the purchase of parliamentary support for the approval of projects of government interest in the administration of Luiz Inácio Lula da Silva, from the Workers' Party (PT). Forty politicians and leaders of the PT were condemned by the Federal
Supreme Court.

${ }^{16}$ James Louis Cavallaro and Raquel Ferreira Dodge, "Understanding the São Paulo Attacks," ReVista Harvard Review of Latin America Online, Spring 2007, available at $<$ https://revista.drclas.harvard.edu/book/ understanding-s\%C3\%A3o-paulo-attacks $>$.

${ }^{17}$ Jacob Waiselfisz, "Mapa da violência” (Brasília:

UNESCO, 2013), 43.

18 "SP tem a menor taxa de homicídios do Brasile redução de 46\% nos assassinatos de 2006 a 2016, diz Atlas da Violência," G1, May 05, 2018, available at < https:// g1.globo.com/sp/sao-paulo/noticia/sp-tem-a-menor-taxade-homicidios-do-brasil-e-reducao-de-46-nos-assassinatos-de-2006-a-2016-diz-atlas-da-violencia.ghtml>.

${ }^{19}$ Graham Denyer Willis, The Killing Consensus: Police, Organized Crime, and the Regulation of Life and Death in Urban Brazil (Oakland, California: University of California Press, March, 2015).

${ }^{20}$ Ibid.

${ }^{21}$ Gil Alessi, "Acordo pela paz entre PCC e Comando Vermelho derruba homicídios em Fortaleza," El Pais, August 26, 2016, available at <https://brasil.elpais.com/ brasil/2016/08/19/politica/1471617200_201985.html>.

${ }^{22}$ Max G. Manwaring, "Street Gangs: The New Urban Insurgency,"Strategic Studies Institute Monograph, 3/1/2005 (Carlisle, PA: U.S. Army War College, 2005) 1-47, available at $\mathrm{K}<\mathrm{www}$.strategicstudiesinstitute.army.mil/pdffiles/PUB597.pdf $>$.

${ }^{23}$ Alfredo Carrijo, "Countering the PCC: A New Federal Government Approach,” Masters Thesis, National Defense University's College of International Security Affairs, 2018.

24 "TSE alerta para necessidade de monitorar atuação do crime organizado nas eleições," Tribunal Superior Eleitoral (TSE) October 10, 2017, available at <1www.tse.jus.br/imprensa/noticias-tse/2017/Outubro/ tse-alerta-para-necessidade-de-monitorar-atuacao-do-crime-organizado-nas-eleicoes-1>.

${ }^{25}$ Fausto Macedo and Mateus Coutinho, "Prefeito de Embu acusado de lavar dinheiro do PCC toma posse," $\mathrm{O}$ Estado de S. Paulo: São Paulo, September 2, 2017, available at <http://politica.estadao.com.br/blogs/fausto-macedo/ prefeito-deembu-acusado-de-lavar-dinheiro-do-pcctoma-posse/>; see also José Maria Tomazela, "PCC financiou campanha de vereador eleito, diz Ministério Público," available at <https://sao-paulo.estadao.com.br/ noticias/geral,pcc-financiou-campanha-de-vereadoreleito-diz-gaeco,10000083373>.

${ }^{26}$ Aline Ribeiro, "Estados temem facções criminosase pedem ajuda nas eleições," O Globo, August 09, 2018, available at <https://oglobo.globo.com/brasil/estados-temem-faccoes-criminosas-pedem-ajuda-nas-eleicoes-23052734>. 
${ }^{27}$ Charles Parkinson, "Brazil's PCC Attempting to Enter Politics," October 14, 2013, available at <http://www.insightcrime.org/news-briefs/ brazils-pcc-attempting-to-enter-politics $>$.

${ }^{28}$ Eleonora Gosman, "Con candidatos propios, los narcos controlan las elecciones en favelas de Río y San Pablo," Clarin, September 16, 2018, available at <https:// www.clarin.com/mundo/candidatos-propios-narcos-controlan-elecciones-favelas-rio-san-pablo_0_HkHe3SnO7. html>.

29 “A ação política do PCC," Isto É, July 2016, available at <https://istoe.com.br/acao-politica-do-pcc/>.

${ }^{30}$ Alexandre Hisayasu, "27 facções disputam controle do crime organizado em todos os Estados do País” Estadão, January 07, 2017, available at <http://brasil.estadao.com.br/noticias/ geral,27-faccoes-disputam-controle-docrime-organizado-em-todos-os-estados-do-pais,10000098770>.

${ }^{31}$ Leonardo Coutinho, “O Cartel," VEJA, October 05, 2016, available at <http://faccoesmafiosas.blogspot. com/2016/10/>.

${ }^{32}$ Tristan Clavel, “'Most Wanted’ Peru

Drug Trafficker Captured in Brazil," InSight Crime. Org, September 26, 2017, available at <http://www.insightcrime.org/news-briefs/ most-wanted-peru-drug-trafficker-captured-in-brazil $>$.

${ }^{33}$ Rogerio Jelmayer, Kejal Vyas and Samantha Pearson, "Brazilian Gang Enlists FARC Rebels for Drug Trade,” The Wall Street Journal. January 31, 2017, available at < https://www.wsj.com/articles/brazilian-gang-enlistsfarc-rebels-for-drug-trade-1485858609>.

34 "Revista diz que Beira-Mar confirmou elo com as Farc," BBC Brasil, May 06, 2012, available at <https:// www.bbc.com/portuguese/noticias/2002/020506_colombiaro.shtml>.

35 "Relatorio da Comissão Parlamentar de Inquérito Destinada a Investigar as organizações criminosas do tráfico de armas," Câmara dos Deputados, Brasília (DF), 2006. http://www.observatoriodeseguranca.org/files/relatorio_cpiTraficoArmas_0.pdf

${ }^{36}$ Interviews with the author March, 2018.

${ }^{37}$ Evan Ellis. "Brazil-Between Cooperation and Deterrence," Global Americas Smart News \& research for Latin America's Changemakers, December 18, 2017.

38 "Derrame de fuzis fortalece tráfico e desafia a segurança", O Dia, March 09, 2015, available at <https://odia. ig.com.br/_conteudo/noticia/rio-de-janeiro/2015-03-08/ derrama-de-fuzis-fortalece-trafico-e-desafia-a-seguranca.html>.

39 "Levantamento Nacional de Álcool e Drogas", Universidade Federal de São Paulo, 2012, available at $<$ https://inpad.org.br/lenad/resultados/relatorio-final/>.
${ }^{40}$ Leonardo Coutinho, “O Cartel," VEJA, October 05, 2016, available at <http://faccoesmafiosas.blogspot. com/2016/10/>.

${ }^{41}$ Leonardo Coutinho. "A Amazônia é o novo Rio," VEJA, São Paulo, April 24, 2018.

${ }^{42}$ The official numbers are not known. The data were obtained independently, according to the author's investigation, from the companies responsible for receiving the damaged equipment and its replacement.

43 "Anuário Brasileiro de Segurança Pública 2018," Fórum Brasileiro de Segurança Pública, Rio de Janeiro, August, 2018, available at <http://www.forumseguranca. org.br/wp-content/uploads/2018/08/FBSP_Anuario_ Brasileiro_Seguranca_Publica_Infográfico_2018.pdf $>$.

${ }^{44}$ Interviews conducted by the author with public security managers in the states of Amazonas, Acre, Bahia, Ceará, Minas Gerais, Pará, Rio de Janeiro, Rondônia, Roraima and São Paulo.

${ }^{45}$ Leonardo Coutinho, "Hugo Chávez, o espectro. Como o presidente venezuelano alimentou o narcotráfico, financiou o terrorismo e promoveu a desordem global," Vestígio, São Paulo, March, 2018.

${ }^{46}$ Luís Flávio Sapori e Gláucio Ary Dillon Soares, "Por que Cresce a Violência no Brasil?" Autêntica Editora e Editora Puc Minas, 2014.

${ }^{47}$ Afonso Benites, "PCC movimenta mais de 100 milhões de reais nos EUA e na China," El País, January 18,2015 , available at <https://brasil.elpais.com/brasil/2015/01/16/politica/1421442251_840140.html>.

${ }^{48}$ Francisco Leali, "Polícia Federal aponta elo entre facção brasileira e Hezbollah" O Globo, November 9, 2014, available at <http://oglobo.globo.com/brasil/ policia-federalaponta-elo-entre-faccao-brasileira-hezbollah-14512269>.

${ }^{49}$ U.S. Department of Treasury, "List of Specially Designated Nationals and Blocked Persons," Office of Foreign Assets Control, available at $<$ http://www.treasury. gov/ofac/downloads/sdnlist.txt $>$.

${ }^{50}$ Leali (2014).

${ }^{51}$ Graziele Oliveira e Marcos Coronato, "Como o Brasil entrou, sozinho, na pior crise da história," Época,São Paulo, April 04, 2016, available at < https:// epoca.globo.com/ideias/noticia/2016/04/como-o-brasilentrou-sozinho-na-pior-crise-da-historia.html>.

\section{Photos}

Page 56. Copyrighted photo reproduced with permission by Folhapress. Photo unaltered.

Page 60. Copyrighted photograph reproduced with permission by Folhapress. Photo unaltered.

Page 63. Copyrighted photpgraph reproduced with permission by Folhapress. Photo unaltered. 


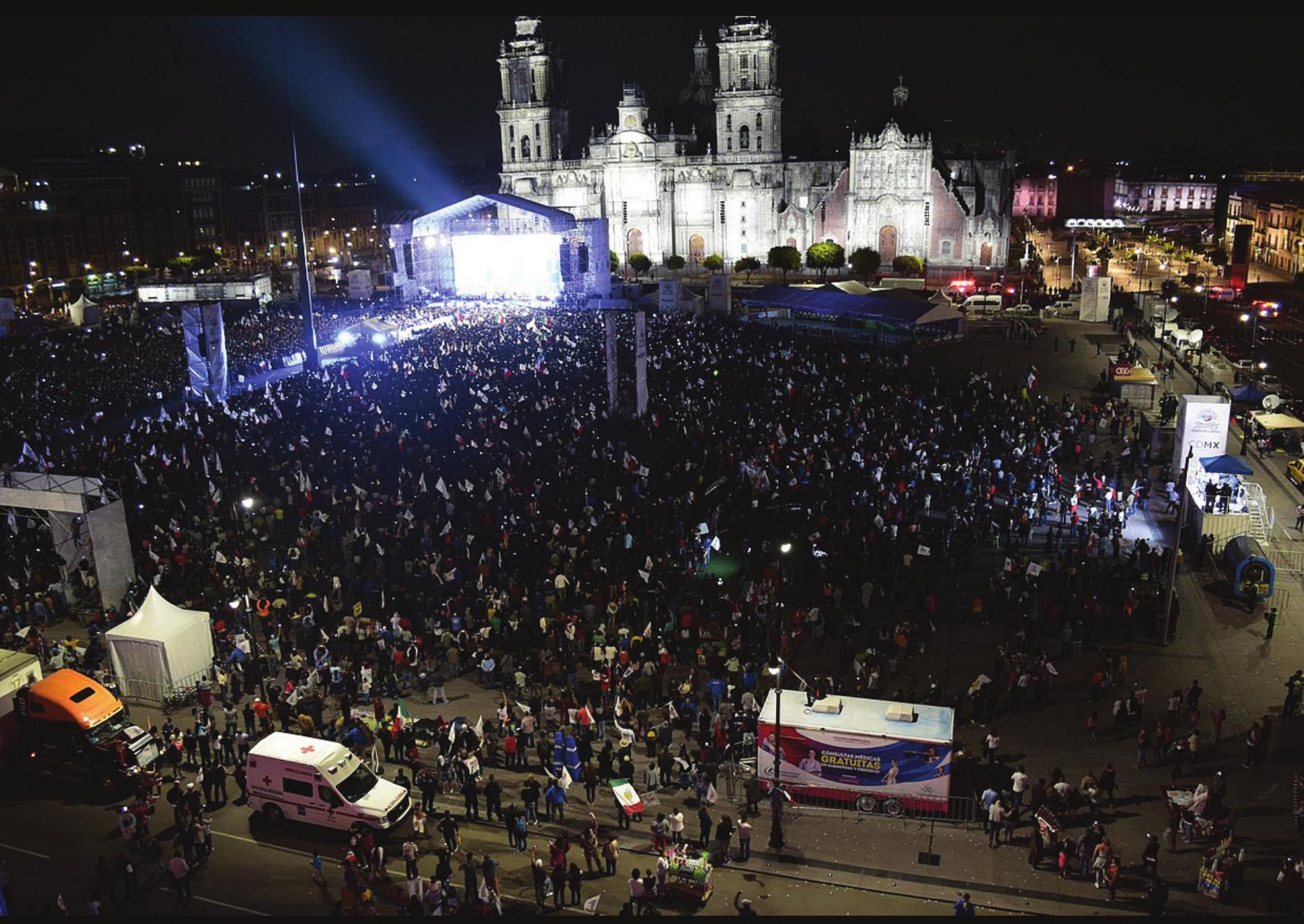

Celebration of Andrés Manuel López Obrador in Mexico City after being declared winner in Mexico's federal election of July 1, 2018. (Wikimedia/Salvador alc) 


\section{Great Expectations and Grim Realities in AMLO's Mexico}

By Mary Speck

ndrés Manuel López Obrador-known simply as AMLO_assumed Mexico's presidency on Dec.
1,2018, with a robust mandate. He won a clear majority in the July 1 national elections, trouncing
rivals from both the conservative National Political Action Party (PAN) and the ruling Institutional Revolutionary Party (PRI). His National Regeneration Movement (MORENA) and its electoral allies will dominate both houses of Congress and took five of the nine state governorships in contention, along with their state legislatures.

Such margins could give López Obrador more federal power than any president since 2000, when Mexico ended seven decades of single-party rule. ${ }^{1} \mathrm{He}$ has promised to use his mandate to launch a "fourth transformation"-i.e. epoch-defining change on the order of Mexican independence in 1821, the liberal reforms of the mid-nineteenth century, and the popular revolution that convulsed the country from 1910 to about 1920. Though as President-elect López Obrador toned down his rhetoric-sounding more like the pragmatic politician he proved to be as mayor of Mexico City—he must still manage high expectations. He has promised voters that he will address poverty and inequality by launching universal pensions for the elderly and providing paid apprenticeships for 200 million youths; help the struggling middle class by freezing fuel prices; revive the energy sector through massive investments in the country's troubled state-owned oil company-all without increasing the deficit. ${ }^{2}$

AMLO must also fulfill hopes for peace in a country plagued by some of the world's most vicious drug gangs. Some 230,000 people were murdered between 2008 and 2017, more than double the number killed in the previous decade. Experts blame up to one-half of these homicides on criminal gangs. ${ }^{3}$ Tens of thousands more have reportedly disappeared. ${ }^{4}$ This tsunami of violence has continued to crest-in July 2018 police recorded the highest level of homicides for any month on-record. ${ }^{5}$

Fulfilling his promise to drastically reduce this violence is López Obrador's most complicated challenge. The president-elect has ignited controversy by seeming to contradict the pacifist promises and slogans-such as offering "abrazos no balazos" or "hugs not bullets" - that characterized his campaign. ${ }^{6}$ But his security policies are still evolving. As President-elect he struggled to define his position on such thorny issues as the

Dr. Mary Speck is a Senior Associate (non-resident) with the Americas Program at the Center for Strategic and International Studies. 
militarization of law enforcement. Nor has he explained how he will finance the country's ongoing justice reforms and strengthen local police. Like his predecessors, López Obrador must grapple with the reality that federal power alone is unlikely to bring the country's highly localized violence under control. There is no populist playbook for building effective police and efficient courts.

As candidate, AMLO vowed to de-militarize the fight against organized crime, but as Presidentelect he has proposed creating a military-controlled National Guard. The new force-drawn largely from the ranks of army and navy-would start at 50,000, growing to 150,000 within three years. ${ }^{7}$ It would operate under command of the Secretary of Defense, an active-duty general. Human rights groups immediately condemned the proposal, urging López Obrador to instead strengthen civilian police forces. ${ }^{8}$

As candidate, López Obrador floated the idea of offering an amnesty to drug traffickers. As President-elect, after hearing from irate victims, he stressed justice, with forgiveness only for low-level, non-violent offenders, and promised that truth commissions would investigate the worst abuses and provide reparations to victims. ${ }^{9}$ During the campaign, AMLO also spoke of legalizing marijuana and permitting the cultivation of opium poppies, though his team may be reconsidering this stance. As President-elect AMLO stressed that Mexico will work within the United Nations to modify international drug control conventions. ${ }^{10}$

The United States has a huge stake in Mexico's success: The criminal organizations responsible for rising violence in Mexico have also fueled a U.S. drug epidemic resulting in 72,000 fatal overdoses during 2017 alone. U.S. agencies have worked closely with Mexican police and military forces to capture drug kingpins; Congress has also appropriated nearly $\$ 3$ billon in equipment, training, and capacity building assistance. ${ }^{11}$ This is only a fraction of the approximately $\$ 14$ billion Mexico spends each year. But by accepting shared responsibility for the illegal drug trade-long a Mexican demand — the United States has secured cooperation on security issues that would have been unthinkable less than a generation ago.

This article examines the evolution of security policy under AMLO's most recent predecessors: Presidents Felipe Calderón (PAN) and Enrique Peña Nieto (PRI). The first began his term with a frontal attack on drug cartels, though he came to understand that Mexico could not control organized crime without social programs and institutional reforms. The second preached demilitarization, embracing violence prevention. But he failed to sustain these efforts, opting instead to institutionalize military interventions. Both failed to enact reforms that would strengthen local police.

\section{Calderón's Crusade}

Calderón took the Mexican public by surprise when he decided to confront the cartels with military force at the start of his term, proclaiming a "national crusade" against crime. ${ }^{12}$ As candidate, he had not placed security issues at the forefront of his campaign, much less argued for a military offensive against organized crime. In his memoir, Calderón would reject the phrase "war on drugs,"-which he dismissed as a slogan coined in the U.S - saying his intention was to end the "cynical impunity" enjoyed by powerful criminals who had infiltrated Mexican institutions..$^{13}$ But those institutions were ill-equipped to handle the fallout as federal troops fought organized crime on multiple fronts. Instead of taking preventive measures, Calderón launched his offensive without considering "how the criminals would respond." 14

He was not the first president to deploy troops in counter-narcotics operations. The army had been eradicating marijuana and poppy crops for decades. His predecessor, Vicente Fox, sent troops to the northern border states under his "Secure Mexico" program beginning in 2005, when the military 


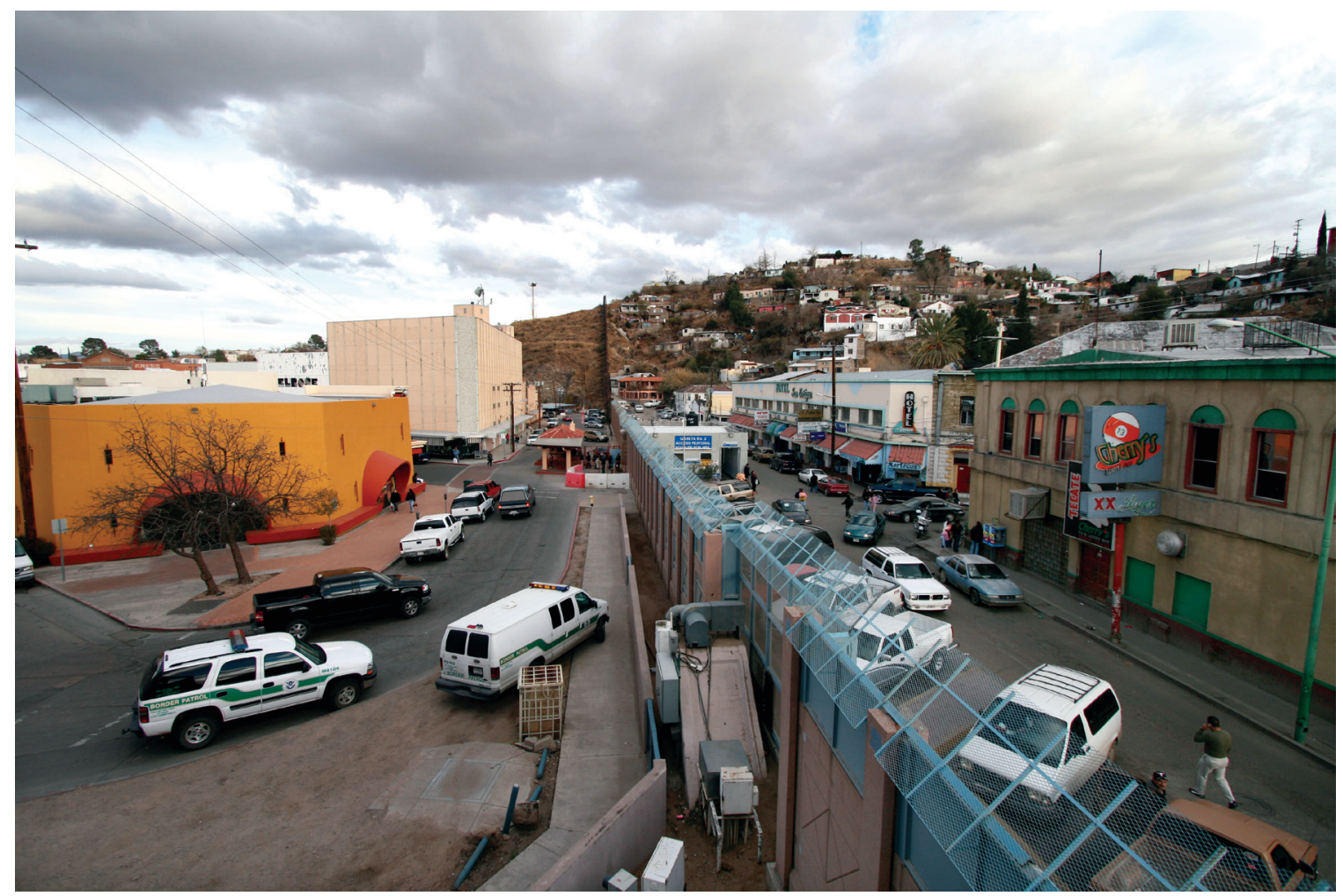

In 2007 the towns of Nogales, Arizona (United States), left, and Nogales, Sonora (Mexico), stand separated by a concrete and steel fence. (U.S. Army/ Gordon Hyde)

removed hundreds of police in Nuevo Laredo for conspiring with drug traffickers. ${ }^{15}$ But Calderón's efforts were on a much larger scale: By the end of 2007, the federal government had launched joint military/police operations in nine of the country's 32 states; at the height of the offensive in 2011 it was deploying about 50,000 soldiers. Calderón also strengthened the federal police, dramatically increasing the force from 6,000 agents in 2006 to 36,000 by $2012 .{ }^{16}$

The mission quickly racked up impressive results, including the seizure of more than $\$ 200$ million in cash crammed into closets, cabinets, and suitcases at an upscale home in Mexico City and the confiscation and destruction of some 23 tons of cocaine (with an estimated street value of about $\$ 2.7$ billion) found in a container ship at the port of Manzanillo. ${ }^{17}$ Calderón also went after so-called "high-value targets" or kingpins, capturing or killing dozens of major traffickers. Powerful organizations, such as the Beltran-Leyva, Tijuana, Juárez, and Gulf cartels, lost top leaders. The hyper-violent Zetas (formed by ex-Gulf hitmen with military experience) were especially hard hit, by both the government and former allies. ${ }^{18}$

It also quickly secured backing from the United States. In March 2007, Calderón and U.S. President George Bush met in the city of Merida, Yucatán, to begin a "new and intensified level of bilateral cooperation" against drug trafficking. From 2008 to 2010, Congress appropriated about $\$ 1.5$ billion for the initiative, including $\$ 421 \mathrm{mil}-$ lion in foreign military funding, which allowed Mexico to purchase aircraft and helicopters. The Obama administration would provide an additional \$425 million from 2011-12. ${ }^{19}$ 
As much or more important than U.S. funding-which represented only a small fraction of the $\$ 14$ billion the Mexican government itself spent each year on security toward the end of Calderón's term-was U.S. cooperation. The Drug Enforcement Administration, along with other U.S. law enforcement and intelligence agencies, worked with vetted Mexican military or federal police units to capture or kill "high-value targets." ${ }^{20}$ Fusion centers allowed U.S. and Mexican agencies to exchange intelligence. Cooperation was especially close with the Mexican navy-a nimbler, less insular institution than the army-whose marine units often took the lead in high-profile counter-narcotics operations. ${ }^{21}$

The United States also helped ensure that captured kingpins would face trial, relieving Mexico's overburdened justice system. Extraditions to the United States increased dramatically under Calderón, who sent nearly 600 suspects to face trial in the United States, twice as many as the total number extradited by the two previous presidents combined. ${ }^{22}$

Less visible-though potentially more important-were efforts to fortify Mexican institutions. The Calderón government passed a series of constitutional reforms in 2008 to transform its judicial system during a period of eight years from a closed-door process based on written dossiers to an adversarial model where defendants can challenge the evidence against them in open court. Mexico has both a federal-court system and 32 state (including the federal district) systems, all of which needed to train judges, prosecutors, and defense attorneys in oral trial procedures for more serious crimes and alternative dispute resolution mechanisms for lesser offenses. ${ }^{23}$

The Calderón government also tried to address deficiencies in law enforcement. It raised selection standards, enacted vetting, and improved training for the federal police while also expanding subsidies for state and municipal police to do the same. It created a national database designed to allow police at all levels to share information. However, it failed to pass its key initiative: a constitutional reform establishing "unified commands" that would have placed municipal forces under the control of state governors.

Although homicides initially fell during 2007, they rose sharply in 2008, peaking at more than 27,000 in 2011, almost three times their level just four years before. The rise was especially steep in states along the border and the Pacific coast where Calderón had sent federal forces to confront the cartels. The government's assault had left drug trafficking groups wounded, but still dangerous. Fragmented criminal organizations engaged in bloody battles for succession or territory, in some cases outsourcing enforcement to street gangs. Federal forces were stretched thin as they took over local law enforcement in multiple hot spots; patrolling urban and rural areas, manning checkpoints, sometimes even directing traffic. ${ }^{24}$ Aggressive tactics led to abuse. Complaints against both the federal police and the military for human rights violations quintupled between 2007-12. ${ }^{25}$

\section{Juárez}

Ciudad Juárez on the U.S. border became a virtual war zone. Aas federal forces took control of law enforcement, homicides accelerated from less than 200 in 2007 to 3,000 in 2010 - a rate of more than 200 per 100,000 people, or about 12 percent of the country's total homicides. Thousands fled across the border into Texas. Outrage over mounting casualties erupted into protests, especially in January 2010 after gunmen, apparently looking for rival gang members, burst into a birthday party in the working-class neighborhood of Villas de Salvárcar, killing 15 people, mostly teenagers. ${ }^{26}$

The massacre of high-school students in a city occupied by federal forces made national and international headlines. The Calderón government, which was already preparing to change tack, decided to make the northern border city its test case for a new approach. "Military action is not 
enough," Calderón told the citizens of Juárez when he announced a major initiative to address violence in February 2010. His government invested more than $\$ 380$ million in the city under a program dubbed Todos Somos Juárez" (We are all Juárez), which financed social programs designed to make communities-especially those with large numbers of un- or underemployed youth-more resistant to violent crime. The idea was to create a multi-sectoral model to address risk-factors while strengthening institutions of justice and law enforcement. The crisis also spurred institutional reforms at the Chihuahua state-level. The state prosecutors' office was purged, subjected to vetting, and offered better training and work conditions. ${ }^{27}$

Although homicides remained historically high, violence was ebbing when Calderón left office in 2013. It subsided especially rapidly in Juárez, which the government cited as vindication of its approach. But the Calderón government remained identified with the militarized counter-narcotics operations blamed for tens of thousands of deaths. The incoming president would publicly repudiate his predecessor's actions even as he adapted or continued many of the same policies.

\section{Peña Nieto's Pact}

When Enrique Peña Nieto took office in December 2012, some feared the PRI's return to power meant restoration of the "democratic authoritarianism"-i.e. periodic elections within a system of de-facto single-party rule - that had characterized PRI governments during most of the $20^{\text {th }}$ century. ${ }^{28}$ He assumed office with great political strength. The PRI controlled not only the presidency but also 21 of the 32 state governments in the country. Although his party failed to win a majority in either house of Congress, the president had already secured support from the country's three major parties for an ambitious reform program dubbed the "Pact for Mexico" before he took office.
By the end of 2013, the Peña Nieto government had passed finance, telecommunications, and education reforms, plus a controversial energy bill that permitted foreign investment in the oil and gas sector for the first time since Mexico expropriated foreign oil companies in $1938 .{ }^{29}$ The youthful president's free-market agenda won him high international praise, including a cover photo on the international edition of Time with the headline, “Saving Mexico: How Enrique Peña Nieto's Sweeping Reforms Have Changed the Narrative in his Narco-Stained Nation." ${ }^{30}$

Peña Nieto also moved quickly to put his stamp on security policy by dissolving the Secretariat of Public Security, created in 2000 under President Vicente Fox, and moving federal police and civilian intelligence back into the interior secretariat. $\mathrm{He}$ promised to take the military out of counter-narcotics operations by deploying a new civilian-controlled gendarmería, a paramilitary force recruited largely from former military officers, which would have 40,000 members. ${ }^{31}$ During his first year in office, Peña Nieto also appeared to put the Merida Initiative on hold, by requiring, for example, that all cooperation go through a "single window" in the interior secretariat, which delayed dispersal of millions in assistance. ${ }^{32}$

The PRI government embraced violence prevention citing efforts in Ciudad Juárez as a model. It created the National Program for the Social Prevention of Violence and Delinquency (PRONAPRED) to channel federal subsidies to state governments for disbursal in more than 50 districts identified as violent hot spots in 2013 and to more than 80 two years later. Municipal governments and civil society groups were to use the funding to identify and address risk factors, reclaim public spaces and strengthen local capacity. ${ }^{33}$

Peña Nieto's new approach soon fell apart. His government never managed to secure political support for the idea of a gendarmerie, which 


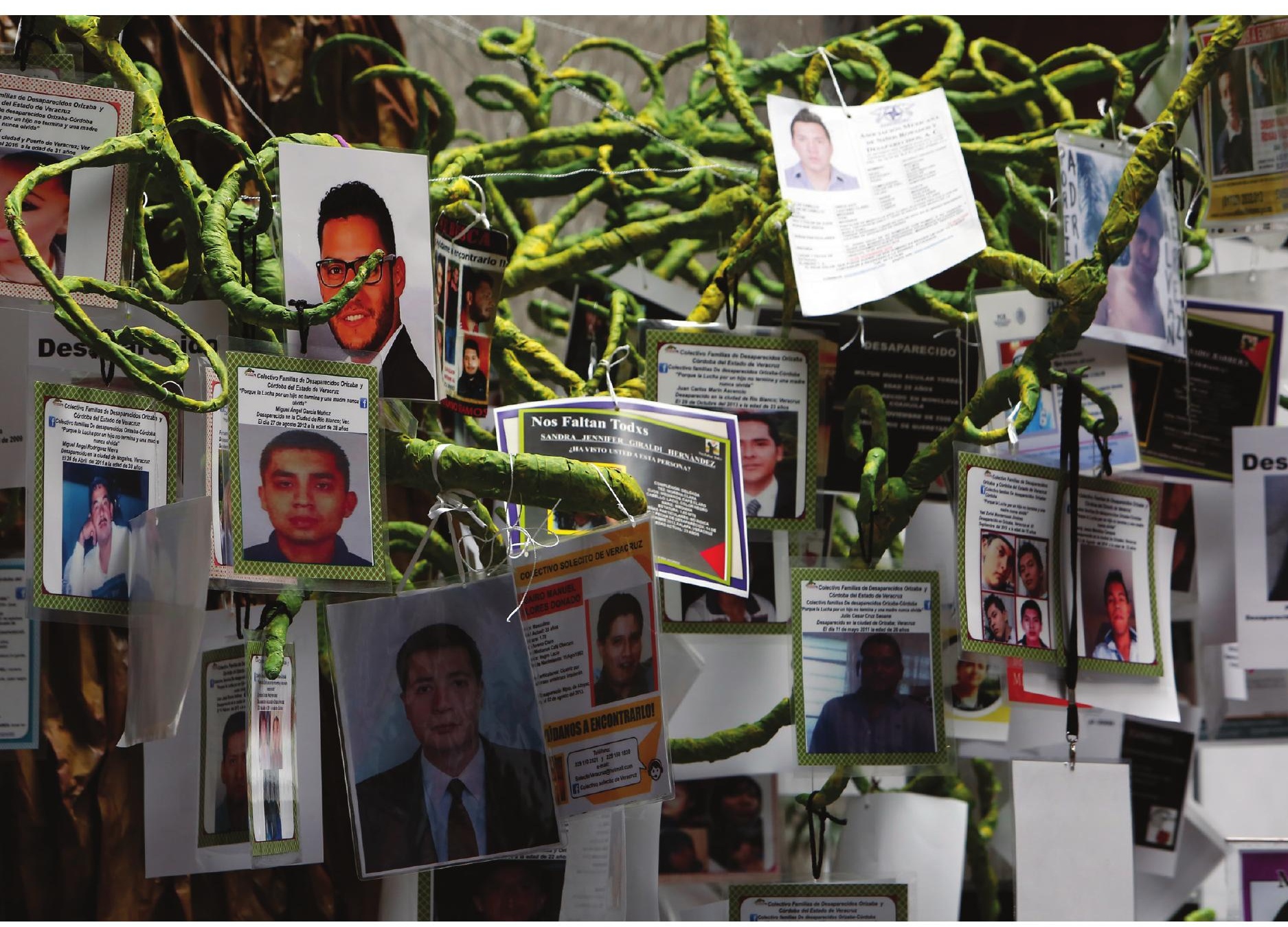

Memorial for the victims of the September 26, 2014 attack by local police on students from the rural college of Ayotzinapa in the city of Iguala, Guerrero, Mexico leaving six people dead and 43 missing. (Inter-American Commission on Human Rights)

fell prey to bureaucratic infighting over responsibilities and budgets. When the new force finally debuted in August 2014, it had been reduced to only 5,000 members. Peña Nieto's proposed constitutional reform mandating unified police commands at the state-level stalled in Congress. Major cities objected to putting their forces under state control and critics questioned whether state police were any more effective or honest than municipal forces. The idea limped along as some states negotiated unified commands municipality by municipality, but results were mixed. ${ }^{34}$

His national violence prevention plan also succumbed to confusion and controversy. The program never developed clear criteria for selecting projects or rigorous procedures for evaluating them. Civil society groups complained that it provided only short-term funding, which arrived months behind schedule, making planning impossible, and that municipal governments selected projects based on 
political, not community, impact. After 2015, the federal government slashed and then eliminated the subsidies amid a series of budget cuts, though some funding returned in 2018. Peña Nieto never overcame the perception that his signature violence prevention program had degenerated into an exercise in political patronage. ${ }^{35}$

Peña Nieto's security policies ended up looking much like his predecessor's. He continued to arrest high-value targets with the help of U.S. intelligence, capturing or killing 109 of the 122 traffickers that his government considered most dangerous. The government had less success in bringing these alleged kingpins to justice. By mid-2018 Mexican courts had convicted only four of them. ${ }^{36}$ Like Calderón, Peña Nieto sent the most notorious to the United States for trial, including Joaquín Guzmán, the Sinaloa Cartel chief known as "El Chapo," who after escaping twice from Mexican prisons faced trial at a federal district court in Brooklyn, NY. ${ }^{37}$

Peña Nieto's reliance on the military to capture "high-value targets" and to patrol high-crime areas sparked opposition both from human rights groups and within the military itself. "We did not train to pursue criminals," Defense Secretary Salvador Cienfuegos told journalists in December 2016, voicing an unusually public critique. "We are assuming duties that are not ours because there is no one else." ${ }^{38}$ The president acceded to the military's demand that its role be "regularized," pushing a new Internal Security Law through Congress in December 2017. The law gives the president authority to order the armed forces to take on police functions in high-crime areas, while giving the military greater autonomy to identify threats, lead operations and collect intelligence. Critics argue, however, that it violates Mexico's constitution by expanding the armed forces' jurisdiction over civilians without subjecting them to civilian oversight. The Supreme Court started to review various challenges to the law-including suits filed by eight municipal governments-in early 2018. ${ }^{39}$

While he institutionalized use of the military for domestic security, Peña Nieto did little to strengthen police. The size of the federal police remained at about 37,000, increasing by only 400 during six years. The federal government also failed to increase the subsidies sent to the states for security, though according to its own diagnosis, the country should double the number of state police. Of those currently serving, only about 40 percent had passed basic competency exams and only 10 percent had completed training in criminal investigation. Thousands remain on state forces, despite failing background checks. ${ }^{40}$

Peña Nieto's government faced problems beyond its control, such as weak oil prices that shrank government revenues and slowed economic growth. Anger over corruption and cronyism-especially his wife's purchase of a $\$ 7$ million home on favorable terms from a government contractor-also undermined his popularity. But the greatest scandal faced during the Peña Nieto government was its bungled response to one of the country's most horrific atrocities.

\section{Ayotzinapa}

On September 26, 2014, local police in the city of Iguala, Guerrero, attacked several busloads of students from the rural teaching college of Ayotzinapa leaving six people dead and 43 missing. Instead of immediately ordering a federal investigation, the Peña Nieto government spent eight days dithering with the state government over who should take responsibility. Then it launched a massive federal probe that arrested more than 100 people, including 70 municipal police who allegedly turned the students over to local gang members who then executed them, incinerating their remains. But it dismissed allegations that federal and state authorities - who reportedly knew about the disappearances in real time and failed to act-were at all complicit or negligent. 
Prosecutors rushed to close the case with the attorney general himself presenting their findings in January 2015 as "the historic truth," though investigators had been unable to find or identify most of the students' remains. To quell the outcry, the government invited international experts to review its investigation. That too backfired when the commission issued a scathing 500-page report detailing inconsistencies and irregularities, including the possible torture of suspects. ${ }^{41}$ Meanwhile the search for the missing students spurred the relatives of other missing persons to demand justice. Around the city of Iguala, relatives-who called their loved ones "the other disappeared"- -discovered dozens of unmarked graves, often acting on anonymous tips. Human and victims' rights groups also intensified efforts to find such clandestine cemeteries in other states with unsolved disappearances, which according to a government registry have reached about 37,000 nationwide. ${ }^{42}$

Peña Nieto invoked the Ayotzinapa tragedy when he launched a ten-point security strategy in November 2014. It repackaged some previous proposals, such as Calderón's state-led unified police commands, and added a reform that would establish procedures for the federal government to take over corrupt municipal governments. He even echoed his predecessor's slogan about the still-popular initiative in Ciudad Juárez, declaring "We are all Ayotzinapa" as he proposed additional social and economic investment in the region. ${ }^{43}$ The constitutional amendments affecting local governance-which would have transferred considerable authority away

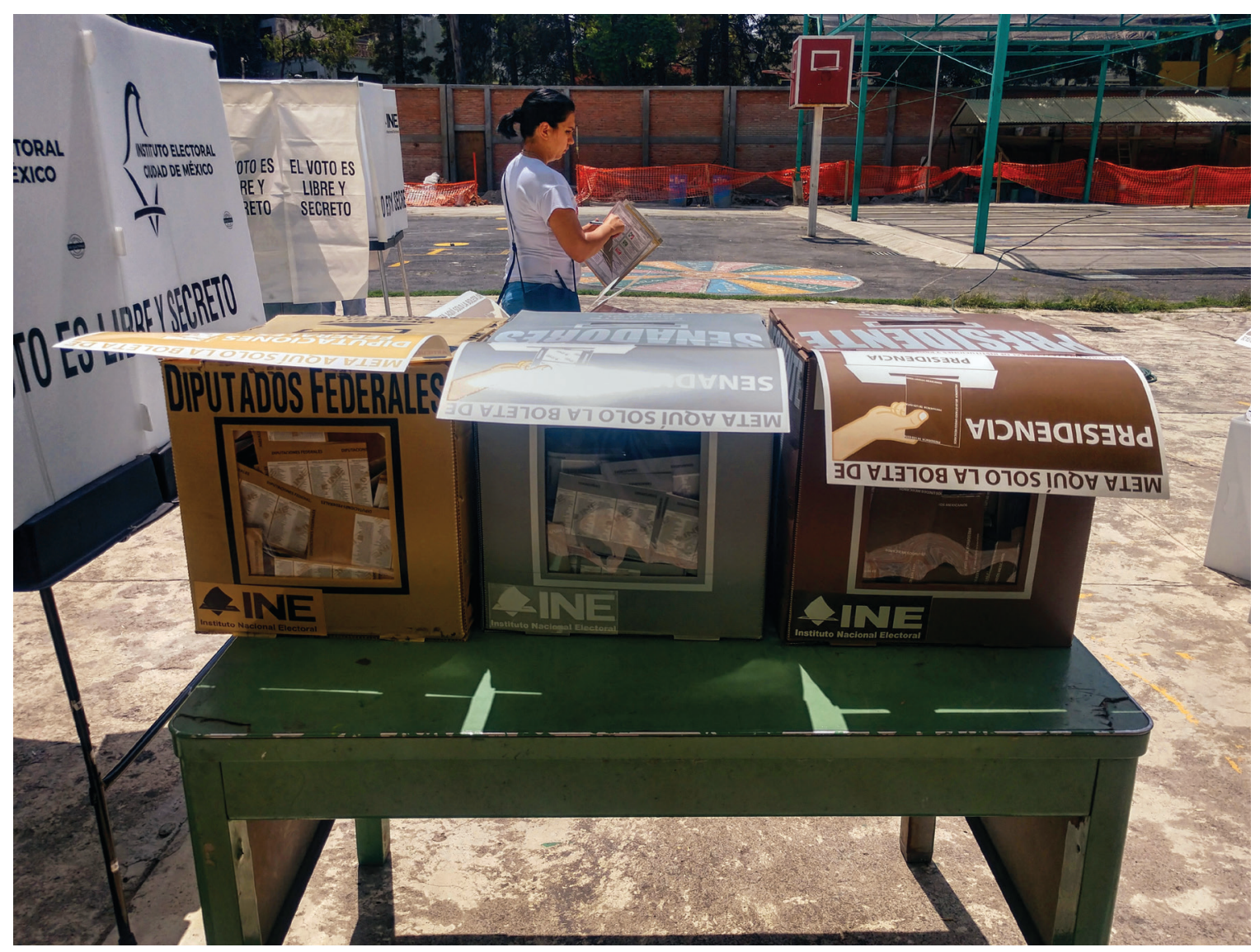

A woman votes in Mexico City during the country's general election on July 1, 2018. (Wikimedia/ProPlasmaKid) 
from municipalities—-died in congress, though the government did push through legislation to strengthen laws on torture and enforced disappearance. A year later Peña Nieto, whose approval ratings had fallen sharply, appeared to have abandoned much of his November strategy. ${ }^{44}$

With local police reform impossible, the federal government's main tool remained the deployment of military force. In the wake of the Ayotzinapa disappearances, the government sent troops to take over law enforcement in a dozen Guerrero municipalities. Nonetheless homicides continued to rise in the state, including in the municipalities where federal police or military troops provided public security. Locals complained that while federal forces set up checkpoints and patrolled highways in heavily armed convoys, they did little to protect ordinary people from violence or predatory crimes, such as extortion. Criminal gangs could simply retreat to outlying areas, temporarily lowering their profile until federal forces withdrew. ${ }^{45}$

The Ayotzinapa disappearances were not the only atrocities involving security forces during Peña Nieto's government, nor were local police the only perpetrators. In July 2014, the army shot 15 alleged kidnappers in Tlatlaya, Guerrero; in January 2015, federal police shot at least six demonstrators in Apatzingán, Michoacán; and in May 2015 federal police killed 42 alleged members of the Jalisco New Generation Cartel in Tanhuato, Michoacán. In the Tlatlaya and Tanhuato cases, the National Human Rights Commission found evidence that federal forces shot the victims after they had surrendered and then tried to make it appear they had died in a fire fight. In Apatzingán it found that federal police used excessive force against unarmed civilians, executing at least one of the victims. ${ }^{46}$

Ayotzinapa struck an especially deep chord, however, because it involved young students with no apparent link to organized crime. The Escuela Normal Rural Raúl Isidro Burgos in Ayotzinapa, moreover, has a long history of leftist activism, giving its supporters the determination and means to keep the issue alive. Peña Nieto's government would never recover from its mishandling of the tragedy, especially as homicides, which had declined during the first two years of his term, started trending upward.

\section{Diffusion and Diversification}

On July 2, while many Mexicans were celebrating López Obrador's historic victory, gunmen intercepted a red pickup truck in Tecalitlán, Jalisco, killing Victor Díaz, the municipality's 28-year-old mayor, in a barrage of AK-47 fire. ${ }^{47}$ The assassination was far from unique; criminals murdered some 152 politicians and activists during the 2018 campaign, plus more than 350 non-elected officials. Most of these political cadres (125) were involved in municipal politics; a much smaller number were competing at the state level (26); only one was campaigning for federal office. ${ }^{48}$ Many bore the hallmarks of organized crime hits; interception by a vehicle filled with heavily armed men who quickly dispatch their victims with automatic weapons fire.

Police are also dying in record numbers. 2017 was the deadliest year yet for police; nearly 400 , mostly municipal officers, were killed on duty. 2018 may match that record-240 had suffered violent deaths by late August. ${ }^{49}$

Tecalitlán (once best known for its mariachis) had already made national news twice before in 2018. In January, the president and secretary of defense visited the town to inaugurate a new army base, one of three new facilities planned to provide security in the region..$^{50} \mathrm{~A}$ month later, three Italian businessmen went missing while visiting the area. Investigators say they were kidnapped by local police and then turned over to the Jalisco New Generation Cartel or CJNG, a relatively new group now believed to be one of the country's most powerful cartels. ${ }^{51}$

The municipality, which has a population of about 16,000 , is in a dangerous neighborhood; it sits 
within the western Sierra Madre mountain system, which extends along Mexico's Pacific Coast and produces most of the heroin consumed in the U.S. Its mountainsides not only offer an ideal climate for growing opium poppies and marijuana, but also provide cover for labs that fabricate synthetic drugs, using chemicals often made in China and then smuggled via cargo ship to Pacific coast ports. ${ }^{52}$ The five states on the U.S. State Department's "do not travel” list for August 2018 are located either within this corridor (Sinaloa, Michoacán, Colima, and Guerrero) or along the United States border (Tamaulipas). ${ }^{53}$

But while violence remains high along these drug production and trafficking routes, it has also spread to central Mexico. Guanajuato-a major automobile manufacturing center that has opened four new plants since 2014- suffered more homicides in the first six months of 2018 than in all of 2017, when it had an already historically high annual rate of 38 per 100,000 people. ${ }^{54}$ Homicide rates also rose during 2017 in neighboring Zacatecas, a mining and manufacturing center (up more than 500 percent since 2013), Hidalgo (up 260 percent), and Puebla (up 180 percent).

The uptick of violence in central Mexico seems related to increased competition over two lucrative rackets that have taken off in recent years; fuel theft and train robbery. Fuel thieves or huachicoleros (from a slang term for adulterated gas or diesel fuel) are costing PEMEX, the state-run oil company, more than $\$ 1.6$ billion a year. They tap pipelines, board ships or oil platforms and siphon fuel from tanker trucks, sometimes aided by corrupt employees. ${ }^{55}$ Train robbers use rocks or vehicles to obstruct tracks or sometimes loosen rail fasteners to cause derailments. Then they break into the freight cars, rapidly loading waiting vehicles with auto parts or appliances or even bulk goods, like grain and cement. ${ }^{56}$

To carry out such crimes, gangs rely on local support and official complicity or, at least, negligence.
As criminal organizations fracture and diversify into new rackets, the control of local territory becomes increasingly important. This puts mayors and other local officials in the cross fire. Many local leaders are victims of extortion themselves; they pay local gangs off out of municipal coffers to guarantee their own and their community's protection. ${ }^{57}$

\section{Basic Lessons}

There is no single strategy that can quickly overcome the violence consuming many Mexican communities. AMLO can no more save Mexico through massive social programs than Peña Nieto could by enacting sweeping economic reforms or Calderón by deploying tens of thousands of federal forces. Mexico's criminal groups have proven to be as complex as the country itself, with an uncanny ability to mutate and migrate. Change will come community by community, municipality by municipality, and state by state by initiating effective violence prevention programs, ensuring genuine transparency, strengthening civilian law enforcement, and building a justice system that is both efficient and fair.

López Obrador - who repeatedly stated during his campaign that "only I can fix corruption"-must modulate his own insurgent instincts. Institution building is a painstaking process that will require collaboration not only across regions and political parties, but across Mexico's vibrant and vociferous civil society groups, from business and professional associations to universities and think tanks to social activists and human rights defenders. To avoid the mistakes that undermined previous governments, the new president must undertake reforms guided by certain goals or principles:

\section{Violence prevention programs should be} based on evidence, not political expediency, and adapted to achieve outcomes, not political expediency. This means the next government 
needs to define a clear methodology for selecting the municipalities or districts eligible for funding and then help local authorities or non-profit groups develop projects designed to produce measurable results.

2. Transparency is essential to avoid the clientelism and corruption that has undermined both anti-poverty and anti-violence efforts in the past. The selection, monitoring and evaluation of all publicly funded social programs should be subject to public scrutiny and outside evaluation by recognized experts from Mexican universities and think tanks.

3. Demilitarization and police reform should go hand-in-hand. The next president should work with state governors to establish benchmarks for the military to gradually withdraw from its police duties while empowering specially trained and vetted federal police units to take on criminal organizations. States and municipalities must also obtain the funding necessary to recruit more and better police officers by offering them higher salaries, better training and equipment, and merit-based promotions. Police cannot purge themselves of corrupt and abusive officers. External oversight-through independent auditors or civilian review boards-is essential at the federal, state, and municipal level.

4. Justice reform must continue. Truth commissions and special tribunals are necessary but insufficient to address widespread impunity. The new government must find the resources and will to strengthen the capacity of independent prosecutors and the courts, both at the state and federal levels. Although some changes are controversial-especially limits on pre-trial detention-the new system remains Mexico's best opportunity to create a justice system that is both efficient and fair.
The United States, for its part, should continue to accept its shared responsibility for the rise of transnational drug trafficking organizations. Both governments must work together to stop the northward flow of illegal drugs that kill U.S. consumers and the southward flow of firearms that slaughter Mexican civilians. U.S. policymakers must also stop repeating past mistakes-whose costs in blood and treasure are born largely by the Mexican public-by focusing not only on stopping drug trafficking but also, and most importantly, on preventing violence and strengthening law enforcement. In the absence of strong police and a capable justice system, capturing high-value targets has fractured criminal groups, igniting more violence, with little impact on the drug trafficking business itself. The United States should instead concentrate on the long-term task of helping Mexico strengthen law enforcement by sharing expertise to create a new generation of professional police, prosecutors, and judges. PRISM

\section{Notes}

${ }^{1}$ María Amparo Casar, "Morena toma todo," Nexos, August 1, 2018.

2 “Mexico’s López Obrador promises $\$ 7.5$ billion for aid to the elderly and job training for youth," Los Angeles Times, July 4, 2018; “Mexico's Struggling State Oil Company Awaits New President's Risky Fix,” Bloomberg, August 14, 2018.

${ }^{3}$ This article uses the annual homicide statistics collected by Mexico's National Institute of Statistics and Geography, available at < They can be downloaded at: www.inegi.org.mx/sistemas/olap/proyectos/bd/continuas/ mortalidad/defuncioneshom.asp?s=est $>$.

${ }^{4}$ See the federal government registry of missing persons at www.gob.mx/sesnsp/acciones-y-programas/ registro-nacional-de-datos-de-personas-extraviadas-o-desaparecidas-rnped.

${ }^{5}$ Laura Calderón, Octavio Rodríguez Ferreira, and David A. Shirk, "Drug Violence in Mexico: Data and Analysis through 2017," Justice in Mexico, University of San Diego, April 2018, 7; Kate Linthicum, "Mexico opened 2,599 homicide investigations in July - the most ever recorded in a month," Los Angeles Times, August 22, 2018.

${ }^{6}$ Critics accuse AMLO of reneging on long-standing promises. See Josué Eduardo Gómez López, “AMLO 
rompe otra promesa: Ejército seguirá en las calles," La Otra Opinión, August 24, 2018; Sanjuana Martínez, "AMLO, el nuevo rehén del Ejército y la Marina," August 27, 2018.

${ }^{7}$ Jude Webber, "Mexico to create new national guard to fight spiraling crime,” Financial Times, November 1, 2018.

${ }^{8}$ Human Rights Watch, "Mexico: Military

Policing Threatens Rights," November 16, 2018, available at <https://www.hrw.org/news/2018/11/16/ mexico-military-policing-threatens-rights- $0>$.

${ }^{9}$ David Agren, "Fury as Mexico presidential candidate pitches amnesty for drug cartel kingpins," Guardian, Dec. 4, 2017; "Mexico's president-elect pledges justice at security forum," Associated Press, Aug. 7, 2018, www. apnews.com/c10d601c5f9740359c254cb35039f212.

10 "Despenalizar mariguana y amapola: equipo de AMLO dice que acudirá a la ONU para cambiar tratado antidrogas," Animal Político, August 22, 2018.

${ }^{11}$ Claire Ribando Seelke, "Mexico: Evolution of the Mérida Initiative, 2007-2019," Congressional Research Service, July 23, 2018.

${ }^{12}$ Claudia Herrera, Alfredo Méndez, "Ofrece Calderón ganar la guerra al crimen organizado," $\mathrm{La}$ Jornada, January 23, 2007.

${ }^{13}$ Calderón, Retos, 26.

${ }^{14}$ For analysis of Calderón's precipitous decision and his strategic errors, see Eduardo Guerrero Gutiérrez, "La estrategia fallida," Nexos, December 1, 2012.

${ }^{15}$ See Raúl Benítez Manaut, "La seguridad nacional en la indefinida transición: mitos y realidades del sexenio de Vicente Fox" in Paradigmas y paradojas de la política exterior de México: 2000-2006, ed. Humberto Garza, (Mexico City: El Colegio de México-Centro de Investigación y Docencia Económicas, 2010), 184-208.

${ }^{16}$ Benito Jiménez, "Militarizan más; suben muertes," Reforma, July 18, 2018, "Mexico's Drug Cartels,"

Congressional Research Service, Oct. 16, 2007.

${ }^{17}$ Eduardo Castillo, "Mexico Seizes \$206M in Drug Money," Washington Post, March 17, 2007, "Mexico Tries to Show Resolve with Big Drug Seizure,” The New York Times, November 29, 2007.

${ }^{18}$ See "Peña Nieto's Challenge: Criminal Cartels and Rule of Law in Mexico," International Crisis Group, March 19, 2013. For a defense of Calderón's counter-narcotics policies by a former head of the Drug Enforcement Administration, see Robert C. Bonner, “The Cartel Crackdown: Winning the Drug War and Rebuilding Mexico in the Process," Foreign Affairs, May 1, 2012.

19 "U.S.-Mexican Security Cooperation: The Mérida Initiative and Beyond," Congressional Research Service, June 29, 2017, 11.

${ }^{20}$ See journalist Dana Priest on U.S.-Mexican cooperation under Calderón: "U.S. role at a crossroads in Mexico's intelligence war on the cartels," Washington Post, April 27, 2013.

${ }^{21}$ Nick Miroff and William Booth, "DEA intelligence aids Mexican marines in drug war," Washington Post, December 4, 2010.

${ }^{22}$ See "U.S.-Mexican Security Cooperation," Congressional Research Service, for extraditions from 1996 to 2016. Mexico's constitution only allows extradition of its citizens in extraordinary cases. Prior to 1996, Mexico did not consider any cases involving its citizens to be extraordinary. See Mary Beth Sheridan, "Mexico Quietly Extradites 2 to U.S." Washington Post, April 29, 1996.

${ }^{23}$ On the advantages of the new system - and the challenges of implementing it-see Clare Ribando Seelke, "Supporting Criminal Justice System Reform in Mexico: The U.S. Role," Congressional Research Service, March 18, 2013 and the Justiciabarómetro reports published by the University of San Diego's Justice in Mexico Project (justiceinmexico.org).

${ }^{24}$ Ibid.

${ }^{25}$ National Human Rights Commission data cited in Maureen Mayer, "Mexico's Police Many Reforms, Little Progress," Washington Office on Latin America, 3-4.

${ }^{26}$ Calderon, Retos, 62.

27 "Back from the Brink: Saving Ciudad Juárez," February 25, 2015, 12.

${ }^{28}$ See, for example, the commentary of historian Lorenzo Meyer and other prominent academics in "Regreso del PRI, dilema entre autoritarismo y democracia: Lorenzo Meyer," Aristegui Noticias, September 3, 2012.

${ }^{29}$ See "Mexican Expropriation of Foreign Oil, 1938," Milestones: 1937-45, Office of the Historian, U.S. Department of State.

${ }^{30}$ Time, February 24, 2014. See also the opinion column by Pierpaolo Barbieri and Niall Ferguson, both of Harvard University, "Mexico's Economic Reform Breakout," Wall Street Journal, December 26, 2013. The column nodded only briefly toward the problem of drug violence: "In the 1980s and 1990s, Mexico was almost as well known for its financial crises as for its drug wars. Those days are gone.”

${ }^{31}$ Richard Fausset, "Mexico civic groups seek Congress debate on gendarmerie," Los Angeles Times, March 27, 2013; Michael Kane, "Peña Nieto Discusses Proposed Security Force,” InSight Crime, July 19, 2012.

${ }^{32}$ Maureen Meyer, "One Year after Enrique Peña Nieto's Election," Washington Office on Latin America, July 2, 2013.

33 "Back from the Brink," Crisis Group, 17.

${ }^{34}$ Marcos Muedano, "A seis años, Mando Único opera en 17.5 de municipios," El Universal, August 1, 2016; Edna Jaime, "El espejismo del mando único," El 
Financiero, June 8, 2018.

${ }^{35}$ José Andrés Sumano Rodríguez, "Pronapred: mismos problemas, menos recursos," Nexos, February 19, 2018.

${ }^{36}$ Zorayda Gallegos, "El fracaso de Peña Nieto contra los delincuentes más buscados en su Gobierno," El País, July 18, 2018.

${ }^{37}$ Alan Feuer, "Gridlock on the Brooklyn Bridge? Blame El Chapo,” New York Times, August 14, 2018.

${ }^{38}$ Jorge Carrasco Araizaga, "Reprocha Cienfuegos falta de apoyo de Segob; 'no estamos a gusto persiguiendo delincuentes', dice,” Proceso, December 8, 2016.

${ }^{39}$ Ricardo Moya, "Suprema Corte admite 8 controversias contra Ley de Seguridad," El Universal, February 9, 2018.

40 "Modelo Óptimo de la Función Policial: Diagnóstico nacional sobre las policías preventivas de las entidades federativas," Secretaría de Gobernación (SEGOB), April 30, 2018. See also Alejandro Hope, “Algunos números del naufragio," September 3, 2018.

41 "Informe Ayotzinapa: Investigación y primeras conclusiones de las desapariciones y homicidios de los normalistas de Ayotzinapa," Grupo Interdisciplinario de Expertos Independientes (GIEI), September 2015.

${ }^{42}$ See Lizzie Wade, "Mapping Mexico's hidden graves," Science, January 26, 2017.

${ }^{43}$ Dave Graham, "Mexico president vows police reform in bid to quell massacre anger," Reuters, November 27, 2014.

${ }^{44}$ Jesús Badillo, "Un año del decálogo en seguridad de Peña ... sin concretarse,” Milenio, November 25, 2015.

${ }^{45}$ See "Disappeared: Justice Denied in Mexico's Guerrero State," International Crisis Group, October 23, 2015.

${ }^{46}$ Charges against seven soldiers for the Tlatlaya case were thrown out for lack of evidence, though a judge ordered the case re-opened in August 2018. "Juez ordenó a la PGR corregir su investigación para esclarecer el caso Tlatlaya: Centro Prodh,” Animal Político, Aug. 12, 2018. Eight people died when federal broke up a demonstration involving citizen self-defense groups in Apatzingán; the National Human Rights Commission (CNDH) blamed police for six deaths, including one execution. Eugenia Jiménez Cáliz, "En Apatzingán hubo uso excesivo de la fuerza: CNDH,” Milenio, November 26, 2015. In Tanhuato, many of those killed were shot in the back, at close range or in gunfire from a police helicopter, according to the commission, which also found that police had moved the bodies and planted weapons. "10 claves sobre la matanza en Tanhuato-Ecuandureo (Documento de CNDH)," Aristegui Noticias, August 19, 2016.

47 "Tecalitlan, Jalisco: PRI Municipal President Assassinated," Borderland Beat, July 3, 2018.
${ }^{48}$ Etellekt Consultores, "Séptimo Informe de Violencia Política,” July 9, 2018, 16.

${ }^{49}$ Manuel Espino Bucio, "2017, También el más violento para policías,” El Universal, Dec. 28, 2017. Causa en Común, a Mexican NGO, maintains an interactive map of murdered police agents by state. See "Registro de policías asesinados 2018" available at <http://causaencomun.org. $\mathrm{mx} /$ beta/registro-de-policias-asesinados-2018/>.

50 "Inauguran 79 Batallón de Infantería en Tecalitlán, Jalisco, El Debate, January 15, 2018.

51 “Tecalitlán. El ultimo rastro de los italianos," El Universal, March 26, 2018. The state temporarily disbanded the municipal police, sending officers to another town for retraining. Abraham Acosta, "Policías de Tecalitlán no están detenidos, sino en un curso: Fiscalía," Excelsior, February 22, 2018.

52 These include the chemical precursors used for methamphetamines and fentanyl, a synthetic opioid often added to heroin, with potentially lethal consequences. See Kristina Davis and Sandra Dibble, "Fentanyl has taken over America's drug market. Where is it coming from?" San Diego Union, June 17, 2018.

53 "Mexico Travel Advisory," U.S. Department of State-Bureau of Consular Affairs, August 16, 2018.

${ }^{54}$ Andrés Mendoza, "Guanajuato rompe récord en homicidios," Excelsior, July 28, 2018.

${ }^{55}$ Christopher Woody, "Mexico's oil company is losing more than a billion dollars a year to cartels-and its own employees are helping them out," Business Insider, April 13, 2018.

56 "Mexico train robberies rise as thieves block tracks," Associated Press (www.apnews.com) May 28, 2018.

${ }^{57}$ See "Disappeared: Justice Denied in Mexico's Guerrero State," International Crisis Group, October 23, 2015, 19.

\section{Photos}

Page 68. Licensed under Creative Commons Attribution-ShareAlike 4.0 International License. Photo produced unaltered.

Page 71. (U.S. Army/ Gordon Hyde)

Page 74. Transferred from Flickr2Commons to Wikimedia by Warko. Licensed under Creative Commons Attribution 2.0 Generic License. Photo unaltered.

Page 76. Licensed under Creative Commons Attribution-ShareAlike 4.0 International License. Photo produced unaltered. 


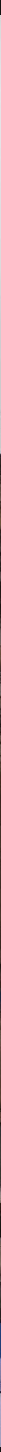

Iván Duque assumes the Presidency; August 7, 2018 at the Bolivar Square in Bogota, Colombia.(Presidency of the Mexican Republic) 


\title{
Security Challenges of the New Colombian Administration
}

\author{
By David E. Spencer
}

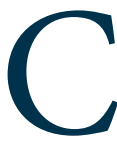

olombia faces one of the most complex security situations in its recent history, as it is simultaneously confronted by four intertwined security challenges-increased drug production, increased organized crime, peace negotiation complications, and a volatile border with Venezuela-that have formed a perfect Gordian Knot. The new administration led by President Iván Duque must cut this knot to maintain the security advances made by its preceding administrations during the past two decades.

Drug trafficking reached new records in 2017; during this year coca crops were estimated to extend to 209,000 hectares, with 921 metric tons of cocaine production annually. ${ }^{1}$ By contrast, there were 136,000 hectares of coca producing around 500 metric tons of cocaine when the U.S. Congress deemed it enough of an emergency to implement Plan Colombia in 1999. ${ }^{2}$ Many of the peasants who had hoped to benefit from reconstruction and crop substitution programs have instead opted for the higher profits and greater market security of coca cultivation. The increased cocaine production has caused a corresponding explosion of organized crime and violence, to include the presence of Mexican cartels, strengthened criminal groups; National Liberation Army (ELN) guerrillas; and an increasing number of FARC (Revolutionary Armed Forces of Colombia) dissidents. Progress on peace accord implementation has been weak; resources have been inadequate, and implementation has been inefficient and poorly coordinated. Further destabilizing Colombia's security situation, Venezuela's political, economic and social crisis, threatens to spillover and derail Colombia's peace process.

In many ways Duque's election in June, was a referendum on the country's unhappiness with the peace accord negotiated by his predecessor, Juan Manuel Santos, with the FARC guerrillas. Duque, representing the opposition coalition led by former president Alvaro Uribe, won a clear victory over former senator and Bogota mayor Gustavo Petro, 54 to 42 percent. ${ }^{3}$

However, the election also revealed how divided the country is over the peace agreement, not so much because of the voting percentages, but rather because of the significantly polarized platforms of the two leading candidates. One of the principle aspects that facilitated the enormous security gains of the pre-Santos, Uribe administration (2002-10) was the remarkable consensus that came together behind the President to prosecute the war against the FARC and ELN insurgencies, combat drug trafficking, and demobilize the so-called paramilitaries. An equally remarkable consensus developed in the United States among Democrats

Dr. David Spencer is an Associate Professor at the William J. Perry Center for Hemispheric Studies. 
and Republicans in Congress that provided significant moral and material support to three successive Colombian presidents to combat drug trafficking and defeat terrorism through Plan Colombia. Disagreements over the peace negotiations with the FARC during the Santos administration shattered the consensus in Colombia. Surprisingly, the consensus in the United States has remained intact, but has grown fragile given the recent accelerated growth of coca crops and the fragility of the peace process. It may remain intact as the new Colombian administration's positions are closely aligned to the United States' concerns. However, these challenges may be greater than the time and resources allotted to President Duque. Reviewing these challenges in detail will help us understand what he is up against.

\section{Increased Drug Production}

Coca crop reduction is a top priority for the Duque administration. The 2016 peace accords agreed to end aerial spraying and replace it with crop substitution and voluntary eradication, with which the FARC had agreed to help. Experimentation with crop substitution in Catatumbo and Putumayo began in 2013 but did not go well. Coca crops expanded and money spent on the substitution programs failed to produce demonstrable results. Nevertheless, nationwide crop spraying effectively ended in the last quarter of 2015 as a demonstration of good faith by the government to FARC, but crop substitution and voluntary eradication did not start up until the end of 2016. As a result, coca crops shot up from around 78,000 hectares in 2012 to 209,000 hectares in $2017^{4}$

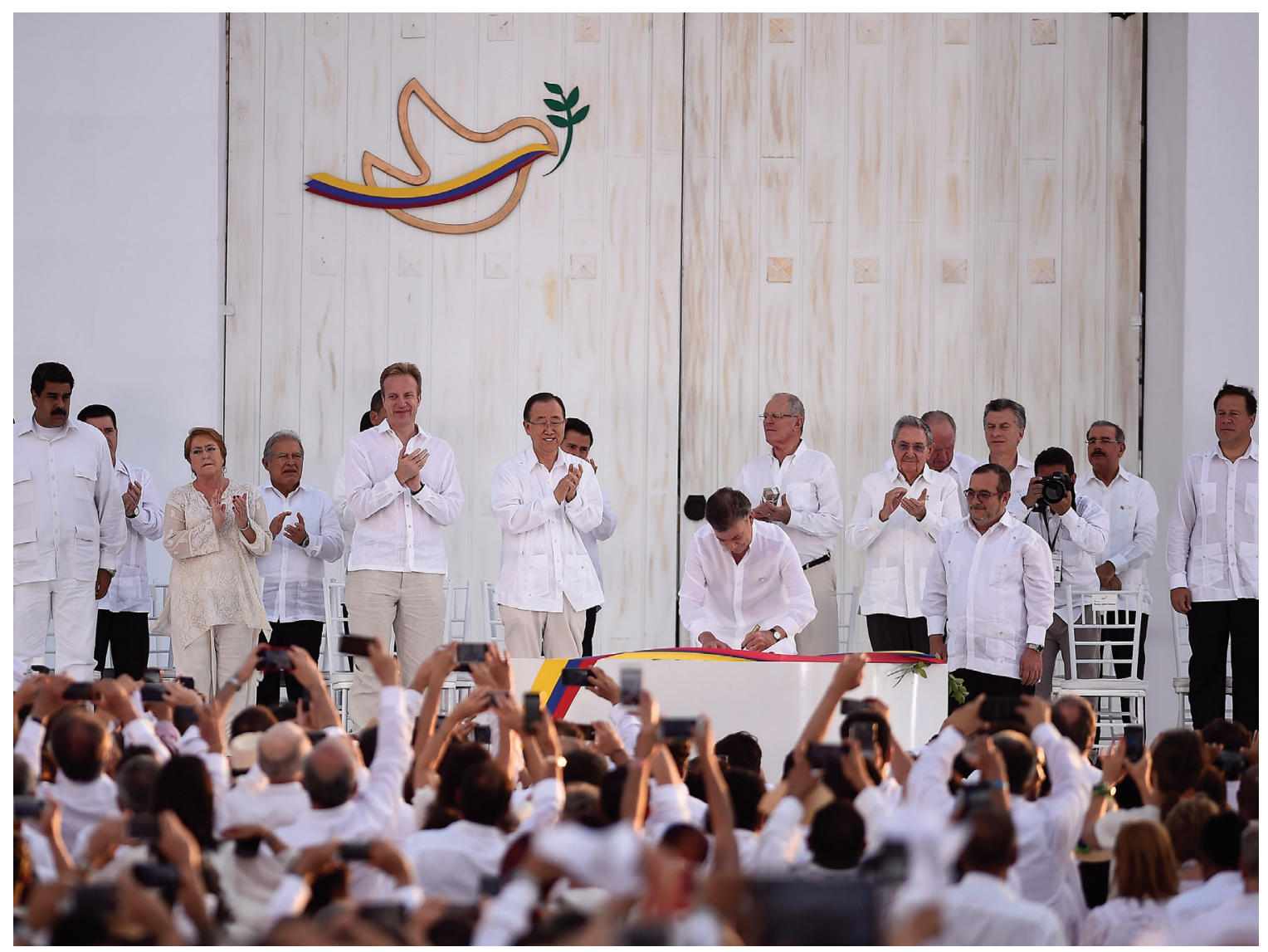

On September 26, 2016 Colombian President Juan Manuel Santos signs historic peace agreement with the FARC. 
Substitution and manual eradication simply have not been able to keep up with the explosion of coca cultivation. So far, the estimated 83,000 families that have signed up for the substitution program only control an estimated 49,000 hectares of coca, or 23 percent of Colombia's 2017 coca crop. As of August, first payments had been made to some of the families, and more than 26,000 (56 percent) hectares of a planned 50,000 for 2017 had been voluntarily eradicated and verified by the UN (12.4 percent of all of Colombia's 2017 coca estimate). ${ }^{5}$ Coca eradication goals for 2017 were 100,000 hectares of coca (50,000 via voluntary eradication and 50,000 via forced eradication). Last year the goal was 110,000 hectares of coca (40,000 voluntary and 70,000 forced). By the end of June, the combined results from 2017 and 2018 reported by the government were the forced eradication of 70,000 (58 percent of goals) and 26,000 voluntarily eradicated hectares (29 percent of overall target). Between voluntary and forced eradication they have reached just under 46 percent of their combined 2017/18 goals. ${ }^{6}$ What is clear, is that the efforts of the past two years are simply not keeping up with replanting as the overall crop figures continue to grow despite eradication. From $2016-17$ they grew by 11 percent.?

Furthermore, there are at least a similar number of families, controlling a roughly equivalent number of coca hectares that are eligible for the crop substitution if the government is serious about having a real impact. However, the substitution program is enormously expensive for dubious results. If we extrapolate from the figures above, to voluntarily eradicate 100,000 hectares of coca, or roughly half of the 2017 crop estimate, the government would need to sign up a total of 166,000 families. Under the current program, each family receives a benefit package equivalent to $\$ 11,000$ per family during two years. In other words the amount needed would be $\$ 1.8$ billion total or roughly $\$ 900$ million per year. By comparison, the drug spraying operations funded by the United States cost about 65 million dollars per year. ${ }^{8}$ So far, the Colombian state has not been able to provide that level of funding. From 2016-18 the Colombian government spent 525 billion pesos or roughly $\$ 175$ million on the program (less than 50 percent of the cost for the families currently in the program and far less than amount required to make a real dent in cultivation). ${ }^{9}$ Clearly something additional needs to be done, and the Duque administration is convinced that reviving spraying is the answer they seek.

Legislation to revive aerial spraying is already in the works. However, to avoid the accusations of collateral damage, the administration is talking about spraying with drones versus aircraft, although it is not clear whether such drones currently exist or if they will have to be invented (experimentation with off-the-shelf drones has not been encouraging).${ }^{10}$ How to resolve the crop reduction problem while striking a balance between eradication and substitution is a conundrum which the Duque administration needs to make a top priority.

\section{Narcotics Lead to Increased Organized Crime}

The main reason Colombia is interested in reducing coca crops is to reduce the accompanying criminality and violence that is making governance of the rural areas and peace implementation so difficult. Violence inevitably accompanies the illicit drug trade because, since there is no law that regulates it, the only way to make sure that agreements are fulfilled is through force. It logically follows that where there is more at stake, the need for force is greater, so the violence accompanying drug trafficking is very high due to the enormous profits that are generated. Force is used to prevent rivals from taking over the business, to take business away from others, to enforce agreements and to resist the efforts of the state to disrupt the criminal enterprise. 
As the global demand for illicit cocaine burgeons, in Europe, in Asia and even Latin America, criminal organizations that dominate the trade have become more sophisticated, often now resembling armies, in many cases using equipment and carrying weapons that are more advanced than those being carried by the police and militaries that confront them. ${ }^{11}$

Colombia did initially experience a significant reduction of violence in the rural zones where the FARC had been dominant before demobilization. However, soon afterward guerrilla organizations, criminal organizations, the ELN guerrillas, and dissident FARC immediately began filling the vacuum. The levels of violence have been rising ever since. ${ }^{12}$ One of the most disheartening developments is the growth of the dissident FARC.

When the FARC demobilized, the Colombian government anticipated that a small minority would refuse to adhere to the peace process. Just as anticipated, several hundred guerrillas did not join the rest in the demobilization camps. It was expected that these groups would devolve into purely criminal gangs without ideology that would be gradually hunted down and incarcerated. However, instead of shrinking, the dissidents have grown. An article in Semana magazine last July asserted that some of the 29 dissident groups were attempting to reconstitute the FARC..$^{13}$ It indicated that the number of dissidents, reported as less than 500 shortly after demobilization, has now tripled to nearly 1,500 . They are comprised of the initial group that never demobilized, those that demobilized and have now returned to the jungle, but more importantly, new members who have been aggressively recruited by the groups. According to Semana, the dissidents' objective was to reach 8,000 by the end of this year. This would be at least as many, if not more than the number of FARC guerrillas that demobilized in early 2017. Another source of potential recruitment are the thousands of FARC militias that were never identified or demobilized with the main force.

The one puzzling aspect of the new FARC is although they talk of revolution, according to Semana, they do not seem to be interested in taking power, but instead in dominating the drug trafficking industry. They reportedly control routes in Colombia, Brazil and Venezuela, and assassinate community leaders advocating for voluntary eradication in exchange for government benefits packages. ${ }^{14}$

The real issue of concern is the nature of the relationship between the dissident FARC and the demobilized FARC. While it has been commonly asserted that there was little or no connection between demobilized and dissidents, recent events provide the basis to question that assertion. In April 2018, the Colombian Fiscalia (Prosecutor General) arrested FARC leader, Seuxis Paucis Hernández Solarte, AKA Jesus Santrich, for allegedly conspiring to traffic 10 tons of cocaine to the United States. Santrich was a member of the FARC High Command and the headquarters staff of the Caribbean Bloc. He was also one of the principal negotiators of the peace agreement in Havana, Cuba. His arrest was an enormous political embarrassment to the FARC. Santrich was slated to occupy one of the 10 non-competitive legislative positions, conceded to the FARC as part of the peace agreement for two electoral periods. After that, the FARC will have to compete for those positions. The FARC has not named a replacement to fill this seat.

The Fiscalia also arrested Marlon Marin, the nephew of FARC Secretariat member Ivan Márquez, ${ }^{15}$ who was also the commander of the Caribbean Bloc and another chief member of the peace delegation in Havana. The Fiscalia and the U.S. Drug Enforcement Administration (DEA) had overwhelming evidence that Santrich was going to provide the Mexican cartels with 10 tons of cocaine to ship to the United States. ${ }^{16}$ That cocaine was being provided, at least in part, by FARC dissidents. ${ }^{17}$ 
Although the public presumption has been that Santrich was acting alone and without FARC sanction, this is a probably a pleasant fiction that does not hold up under closer examination.

The FARC - particularly their leadership—is a highly disciplined organization that makes collective decisions and executes them according to a concise plan. Although the FARC may not always succeed, the movement has consistently demonstrated the ability to collectively execute plans designed by their leadership. Early each year, each FARC front, column and company held a conference, where they reviewed the past year's activities, dissected successes and failures, and then made plans for the current year in accordance to the strategic plan. The resulting reports and plans were then submitted to higher headquarters for review and approval. This respect for hierarchy and adherence to strategy was among the reasons that the FARC proved so difficult to defeat.

In this context, it is very out of character for a long-time member of the FARC High Command, and one of the prominent peace negotiators to have carried out something like this without being instructed from above. This not only put his personal reputation at risk, but also the entire peace process. Had he acted alone, it would have been logical for his former comrades to abandon him; instead they jumped to his defense, advocating against his extradition, threatening that this would spell the end of the peace process. ${ }^{18}$

Furthermore, two prominent guerrilla leaders-Ivan Márquez, who is also designated to occupy a Senate seat, and "El Paisa," a former FARC special forces commander known for his daring kidnapping operations, executions and arms trafficking, each left their demobilization areas and went to historical FARC regions in the Southeast where the FARC dissidents have established presence as well. It has been reported that Ivan Márquez is also being investigated for drug trafficking and was probably working in concert with Santrich. ${ }^{20}$ However, the evidence was not consolidated yet, when the Fiscalia decided to move against Santrich. Not surprisingly, it was Ivan Márquez, who was the most vocal in defense of Santrich.

In September 2018, the UN announced that seven additional prominent FARC leaders had abandoned the demobilization zones across the country, evading their security details in violation of the peace accords. ${ }^{21}$ Besides the aforementioned leaders, the deserters include Romaña, Albeiro Córdoba, Iván Alí, Fabián Ramírez Cabrera, Zarco Aldinever, Manuel Político, and Enrique Marulanda-all prominent first-and second-tier FARC commanders. ${ }^{22}$ Other sources indicate that as much as 60 percent of the demobilized guerrillas have left the demobilization zones, many of whom have joined the dissidents, ELN or criminal groups. ${ }^{23}$ While it is too early to predict a collapse of the peace accord, and while other peace processes have gone through similar and even greater crises, these developments are certainly of great concern. The bottom line is that these events call into question FARC's sincerity in terms of truly abandoning crime and points to a possible attempt to use narcotics financed politics to achieve what they could not on the battlefield, an increased share of political power.

\section{Peace Negotiation Complications}

Independent of the FARC or the FARC dissidents, narcotics is undermining the peace agreement in another important way. It is undermining the government's ability to carry out the terms of the peace agreement, and perhaps more importantly to be sufficiently competitive to reduce the attractiveness of participating in the illicit market.

How one views the progress on the peace accords depends on whether one takes the view of a glass half empty or a glass half full. Notre Dame's Kroc Institute has been monitoring and analyzing peace implementation. In August the Institute 
reported that, compared to other peace accords, progress in Colombia was advancing at an average pace. ${ }^{24}$ Of the 578 stipulations in the accord, 61 percent had been acted on to some degree and 39 percent had not yet been implemented at all. Of the 61 percent of the enacted stipulations in the peace accord, about half had been fully or intermediately implemented ( 21 percent and 9 percent respectively) and half minimally implemented (31 percent). ${ }^{25}$ Implementation has been relatively successful in terms of the concentration, disarmament, and demobilization of FARC combatants. Where there are significant concerns is in security and protection for human rights advocates and social leaders; the slow pace of long-term political, economic and social integration, and required implementation legislation. There have also been significant difficulties to implement gender, ethnic, and territorial approaches that are key features of the peace agreement. ${ }^{26}$

The Kroc Institute puts a positive spin on the progress of the peace accord. However, the disappearance of 60 percent of the demobilized guerrillas from the concentration zones, (an estimated 4,200 of the 7,000 that are estimated to have demobilized) and several top leaders of the FARC calls into question this positive view. This is especially true given the evidence that most of these demobilized members are returning to an illegal life with either the dissidents, ELN or criminal bands. It is precisely the government's failure to fully implement the provisions of the accord as identified by the Kroc Institute, that are providing justification for abandonment of the demobilization zones by the former guerrillas.

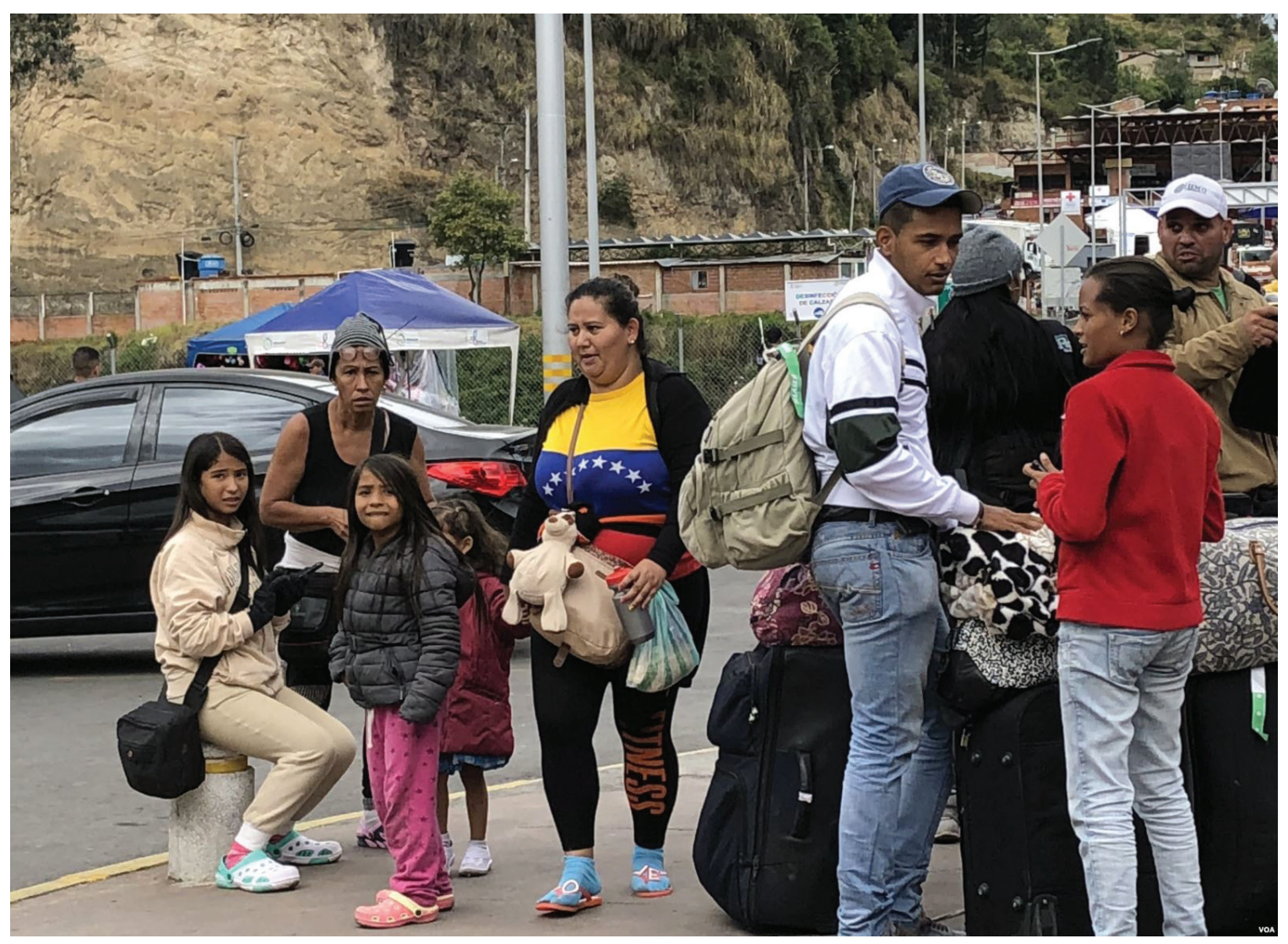

Venezuelans cross the border between Ecuador and Colombia in search of new opportunities. (VOA) 
The Duque government has repeatedly stated that it will not abrogate the peace accord, but has also said that it wants to modify the peace accord to make it viable. One of the major areas where it wants to make the greatest modification is in the treatment of drug trafficking activities. A great triumph for the FARC was when the Santos government agreed to make the crime of drug trafficking by FARC members an offense connected to the conflict; in other words, a crime that was eligible for much reduced penalties and no extradition under the transitional justice agreement known as the Special Jurisdiction for Peace, or "JEP" by its Spanish acronym. Duque wants to go back on this agreement and make drug trafficking activities ineligible for the JEP. He also wants to make drug trafficking organizations ineligible to receive peace benefits as was proposed by some of the militarized criminal bands, and considered by the Santos government.

This could produce a major change in the peace accord, as a large proportion of the FARC fronts were involved to some degree in drug trafficking as a primary source of financing. Large numbers of these fronts' personnel were dedicated to controlling and taxing the illicit business in their areas of operation. While Colombian justice would not likely go after the low-level guerrillas, virtually all of the cadre in these fronts were heavily involved in directing and controlling the illicit business. This could ultimately derail the peace agreement.

One of the things that many analysts keep forgetting is that this is really the first peace agreement that has been implemented in the world in the context of such a large parallel narcotics economy that can be accessed by nearly anyone. Narcotics undermines the government programs because it is more consistent, reliable, and pays at least as much or more, than the government social and development programs which are not as well run, and are significantly underfunded, and inconsistent. Unless the Duque administration makes significant progress against coca cultivation and the drug industry, it is very possible that further progress on peace implementation will be difficult at best, if not impossible.

\section{Volatile Border with Venezuela}

The immediate threat from neighboring Venezuela is mass migration that is overwhelming Colombia's humanitarian and social institutions. However, it is more than just a humanitarian crisis as desperate, unattended migrants are being aggressively recruited by illicit organizations, causing a surge of criminal activity along both sides of the border. These problems are being fed by Venezuelan government mismanagement that has produced hyperinflation, resource scarcity, and economic depression.

In the past couple of years more than 2.3 million people have migrated from Venezuela. This is nearly 8 percent of Venezuela's entire population. This does not include illegal migration or those still in transit, which means the number could be much higher. Some estimates place the figure as high as 4 million. ${ }^{27}$ This is the largest mass migration in recent history on the continent--not due to war, but due to economic collapse and scarcity of basic needs, especially food. The top destinations of Venezuelan migrants in 2017 were Colombia, the United States, Spain, Chile, and Peru. Colombia absorbed the most-more than the next two highest combined. ${ }^{28}$ The Red Cross has reported that from 2014-18 more than a million Venezuelans sought refuge in Colombia. ${ }^{29}$

The quantity of Venezuelan refugees is overwhelming Colombia's absorptive capacity. Additionally, where Colombian policy was initially very generous toward Venezuelan migrants, since February 2018, it has become increasingly restrictive. The current rules lock out many Venezuelans from the formal economy, so that a large proportion are now working informally. This makes them easy prey for armed groups and criminal organizations. Venezuelan youth are being recruited by both along 
the border which operate their enterprises on both sides of the frontier. ${ }^{30}$

These criminal enterprises have a first and second degree cyclical impact on Colombia; they directly impact Colombia with violent criminal activity, and they sustain Venezuela's humanitarian crisis that, in turn, impacts Colombia through an immigration crisis. Many analysts have been dismayed at the ability of the Venezuelan government to stay in power. Historically, many governments have collapsed in the face of similar onslaughts of social protest and international condemnation. Yet, the Venezuelan government continues to survive. Why?

First, the Venezuelan opposition is not as unified as it needs to be, and they are riddled with elements that have been compromised by the regime. Once in power, Chavez found that it was easier to control the opposition by co-opting them with money, rather than to repress them. Many are still receiving benefits from the regime. This makes it impossible for the opposition coalition to be effective, both because significant sectors within the opposition refuse to take a hard line against the regime, and because these same actors keep the government apprised of all of the opposition's plans.

Second, the basic needs emergency in the country has increased the government's control. The government keeps track of those who oppose the government, and those who do not vote for the official candidates or support them. These people do not receive their weekly Local Supply and Production Committee (CLAP) boxes of basic needs supplies. ${ }^{31}$ If one cannot emigrate, receiving a CLAP box can literally determine the difference between life and death. These boxes keep people in line. However, even those who receive the boxes still experience hunger, so they only keep the population in line to a certain degree. Furthermore, the opposition members who do not receive the CLAP boxes are essentially forced to leave; with only the loyalists and those without options remaining behind.

Generally, there are two factors that are keeping the Venezuelan government in power. The first factor is support from China and Russia, seemingly aimed at foiling U.S. policy interests in the region. Even though Venezuela is not repaying their loans, these countries continue to extend credit to Venezuela, for the only apparent reason of sustaining an opponent of the United States in power. Besides money, Russia also sends humanitarian support, such as large shipments of wheat. ${ }^{32}$ The thinking may be that as long as Venezuela irritates the United States, the superpower will pay less attention to Russian and Chinese activities elsewhere. Equally critical to propping up the Venezuelan government is the second factor: criminalization of the State. Venezuela has driven its economy, and its oil industry, into the ground through mismanagement and undisciplined spending; meanwhile, criminal enterprise has systematically taken over. For some years it has been well known that elements of the Venezuelan government, with the encouragement of Hugo Chavez, and now Nicolás Maduro, have increasingly gotten involved in drug trafficking. This may have started out as a way of generating personal wealth, and of generating untraceable money for clandestine activities. However 
now, drug trafficking seems to be a major source of regime income. Colombian cocaine is shipped by land through Vichada and Arauca departments, across the border into Venezuela and flown from that country to the United States and other destinations. This was facilitated by the Chavez' regime's shutting down of U.S. drug trafficking monitoring radars that operated on its territory by agreement with previous regimes. According to deserters it is also known that the Venezuelan government and military officials have been involved in trafficking cocaine from Bolivia to Venezuela and then on to other destinations, including Cuba. ${ }^{33}$ Moreover, the government's involvement has not been limited to drug trafficking, but has extended to nearly all imaginable types of illegal activity.

Whether it is drug trafficking, illegal mining, money laundering, or other criminal enterprises, both the government as a whole, and government officials individually, have been and are heavily involved. Venezuela's national oil company, PDVSA, essentially bankrupt as an oil company, has reportedly become a huge money laundering mechanism for criminal profits. ${ }^{34}$ Therefore, as the regime's money is increasingly from criminal activity, their dependence on the licit economy is much reduced. So, in the short and maybe even mid-term, the Venezuelan government is not vulnerable to traditional international measures such as economic sanctions or other forms of isolation. However, the pressure on Venezuela's legal economy does have an impact on Venezuela's population, particularly those not associated with the regime.

Coca production and trafficking in Colombia feed a vicious cycle that makes the border crisis with Venezuela even more acute. Increased criminality creates increased chaos in Colombia and generates money that strengthens the Venezuelan regime. Thus strengthened, the regime maintains policies which perpetuate the humanitarian crisis, increasing the impact on Colombia through mass migration as well as the increasing numbers of desperate Venezuelans who are being recruited by Colombian criminal and terrorist organizations. Additionally, propped up by Chinese and Russian money and aid that fill the gaps, the regime can sustain itself in the short and perhaps even mid-term. No one should be surprised at the longevity of the regime compared to similar regimes in the past. The criminalization of the Venezuelan state has changed the rules.

The final question is whether or not Venezuela poses a conventional threat to Colombia. Could Venezuela attempt a conventional war to distract its population from the internal crisis? On paper, Venezuela's military looks formidable. Under President Chavez it acquired large amounts of mostly Russian, but also some Chinese military equipment, to include advanced tanks, armored personnel carriers, anti-aircraft missiles, artillery, helicopters, and aircraft, particularly the Sukhoi SU-30 fighter. However, it appears that most of this weaponry might be useful to intimidate the political opposition in Caracas; it looks good on parade, but not much more.

In 2008, Chavez ordered ten battalions to the Colombian border to up the ante with that country, after the latter raided a camp just inside Ecuadorean territory, killing Raul Reyes, one of the members of the FARC secretariat. ${ }^{35}$ The battalions never did fully arrive, and elements of them were strewn for weeks along the entire route between Caracas and the border. Although this was ten years ago, this was also at the apex of Venezuela's power. So, if they were unable to mobilize adequately in 2008 , it is not likely they could do any better today. Subject to the same politicization and mismanagement as the rest of the country, it is highly improbable that Venezuela could mobilize, much less sustain, a conventional conflict with Colombia. This conclusion is supported, for example, by the many videos being circulated on social media of Venezuelan troops looking for food in garbage cans 
like much of the rest of the population. ${ }^{36}$ They have no time to prepare for training or war with Colombia; it takes all of their energy just to survive.

A more likely, but also equally irrational scenario is that after some kind of escalation of tensions between Colombia and Venezuela, the Venezuelans would carry out some sort of single strike against an either symbolic or economic target within Colombia. Venezuela's SU-30s are capable of such a strike against which Colombia is vulnerable. Government buildings in Bogota are obvious political targets, and Colombia's oil refineries are potential economic targets. Colombia's F-21 Kfir fighter aircraft are outdated, and totally outmatched by Venezuela's modern SU-30s. Furthermore, Colombia has little anti-air defense. However, Colombia has a highly developed irregular warfare capability and could carry out guerrilla-style raids nearly at will against Venezuelan forces, lines of supply, communications and infrastructure. So, while a conventional strike from Venezuela is possible, it would produce consequences that the regime could not control, and therefore is highly unlikely. Unless things suddenly change, Colombia need not waste time and resources on worrying about this threat.

\section{Conclusion}

The Colombian government faces a complex mix of internal and external security challenges: implementing peace, criminal organizations, old and new terrorist organizations, and external pressure from a neighboring Venezuela in crisis. All of these are complicated by an exploding narcotics economy caused by a well-intentioned but inadequate crop substitution and manual eradication program in place of the old spraying program. Without narcotics trafficking, or with a much reduced drug trafficking industry, the situation would probably be manageable. But, given the current levels of narcotics cultivation and trafficking, will the Duque administration be able to successfully overcome these threats?
Certainly, the Duque administration seems to be saying the right things. However, so far that is all it has seemed to be, just talk. No substantial new policies have been forthcoming. This is unlike the presidency of Duque's mentor, Álvaro Uribe Velez who, from very early in his 2002 administration, implemented a series of revolutionary initiatives that quickly began to turn the security situation around.

A significant obstacle to this kind of revolutionary policy has been the reduction of state funds due to inflation and a stagnating economy, while there has been a simultaneous increase in obligations due to the peace accords. So, in effect, strengthening of one policy area, has necessarily meant the weakening of another. These trade-offs have caused Duque some problems in a political game where his best outcome may be to minimize losses, rather than maximize gains. Having to deal with problems that he inherited from the Santos government, Duque has claimed that he is not at fault. True or not, now that he in charge these have become his problems. He has to make the tough choices to find the solutions and bear the blame or glory of their outcome.

Duque is not a career politician, but is rather a technocrat and intellectual; this is perhaps simultaneously a strength and weakness. He seems to think that if he can just craft a sufficiently cogent argument, he can convince his opponents of its merits and overcome their opposition. Additionally, he seems to be reluctant to say hard things in an attempt to be friends with everyone. He is not the master political brawler like his mentor Uribe, who could outmaneuver his opponents at every turn, and he is not the coalition builder that was his immediate predecessor, Santos, who orchestrated multi-partisan legislation and policies by doling out quotas of the resulting power to the members.

Duque has renounced Santos' methods because of the real and perceived corruption that it attracted, and he is too nice to practice Uribe's methods. His virtue is his personal morality and his native 
intelligence. However, that leaves him vulnerable to political spin by those who would do him harm. Gustavo Petro, Duque's rival who lost the presidency to him, has used just about any less popular proposal or law to call for social protest, such as Duque's defense of public university education, and most recently, the raising of taxes. ${ }^{37}$ These social protests are becoming larger and increasingly violent. If Duque does not react with intelligent strength, they will make it impossible for him to govern.

This is the key to his success or failure-Duque needs to get out of his comfort zone and demonstrate strong leadership, break a few political eggs (not laws), and not be afraid to assume the consequences. So much of politics is perception, and so far the perception of President Duque has been as a consummate moderate, neither satisfying his would-be supporters, nor pacifying his opposition. His first 100 days have not been decisive. If he does not change the perception and get out in front of the issues, he will lose the support not only of his opponents, but his would-be supporters, becoming a lame-duck president, only holding the line against the security problems until a more decisive government from either side of the political spectrum replaces him, or the country is overwhelmed. PRISM

\section{Notes}

${ }^{1}$ Office of National Drug Control Policy, "New Annual Data Released by White House Drug Policy Office Shows Record High Cocaine Cultivation and Production in Colombia," press release, July 20,2018 , available at $<$ https://www.whitehouse. gov/briefings-statements/new-annual-data-released-white-house-drug-policy-office-shows-record-high-cocaine-cultivation-production-colombia/>.

${ }^{2}$ United States Government Accounting Office, "Drug Control: Coca Cultivation and Eradication Estimates in Colombia," GAO-03-319R Coca Estimates in Colombia, GAO Code 320115, January 16, 2003, available at <https://www.gao.gov/new.items/d03319r.pdf >.

3 "Resultados Electorales 2018," Colombia.com, June 17,2018 , available at $<$ https://www.colombia.com/elecciones/2018/resultados/presidente.aspx?C=P2>.

${ }^{4}$ Office of National Drug Control Policy, “Coca in the Andes," available at <https://obamawhitehouse. archives.gov/ondcp/targeting-cocaine-at-the-Source >.

${ }^{5}$ Fundación Ideas para la Paz, En qué va la sustitución de cultivos ilícitos: Desafíos y recomendaciones para el nuevo gobierno [How is Crop Substitution Doing: Challenges and Recommendations for the New Government], Informe 05, August 2018.

${ }^{6} \mathrm{CNN}$ Español, "Colombia llega a niveles de récord en cultivos de coca y producción de cocaína, según informe de EE.UU" [Colombia Reaches New Record Levels in Coca Cultivation and Production of Cocaine, According to U.S. Report], CNN Español, June 25, 2018, available at $<$ https://cnnespanol.cnn.com/2018/06/25/ colombia-coca-cocaina-record-niveles-altos-estados-unidos-ondcp/>; "El plan para erradicar 110.000 hectáreas de coca en Colombia este año" [The Plan to Eradicate 110,000 Hectares of Coca in Colombia This Year], El Tiempo.com, available at $<$ https:// www.eltiempo.com/justicia/conflicto-y-narcotrafico/ plan-del-gobierno-para-erradicar-cultivos-de-coca-en-colombia-en-2018-236160>.

${ }^{7}$ Ibid.

${ }^{8}$ Notes from a meeting with the Colombian government on crop substitution attended by the author on March 8, 2017.

${ }^{9}$ Op cit Fundación Ideas para la Paz.

${ }^{10}$ David Alejandro Mercado, “'Drones no fumigan coca con la rapidez esperada' [Drones Don't fumigate Coca as Quickly as Expected]: Luis Pérez," ElTiempo.com, December 1, 2018, available at <https://www.eltiempo. $\mathrm{com} /$ colombia/medellin/luis-perez-dice-que-los-dronesno-fumigan-la-coca-con-la-rapidez-esperada-300436>.

${ }^{11}$ Brazil is now the second largest consumer of cocaine in the world, after the United States. See United Nations Office on Drug Control, "World Drug Report 2018," UNODC.org, available at <https://www.unodc.org/ wdr2018/>.

12 "Este año van 3.491 asesinatos: lanzan alerta por aumento del 7 \%" [This year there have been 3,491 murders so far: an alert is sent because of increase of 7\%], El Tiempo.com, available at $<$ https://www.eltiempo.com/ justicia/conflicto-y-narcotrafico/narcotrafico-enemigo-de-la-paz-asegura-fiscal-general-207270>.

${ }^{13}$ Semana magazine was given access to government intelligence for this article. Editorially, Semana has been supportive of the peace accord, so the intelligence was compelling for them to publish this article. Furthermore, this information squares with other reports viewed by the author.

14 "El Plan Para Refundar las Farc" [The Plan to Reorganize the FARC], Semana.com, July 15, 2018, available at $<$ https://www.semana.com/nacion/articulo/ 
refundar-las-farc-el-plan-de-los-disidentes-de-la-guerrilla/575195>.

${ }^{15}$ No relation to President Duque.

${ }^{16}$ Ana Marcos, "Detenido Jesús Santrich, Exlíder de las FARC, por Narcotráfico a Petición de Estados Unidos" [Jesus Santrich Arrested, Ex FARC Leader, for Drug Trafficking by Request of the United States], El Pais.com, April 10, 2018, available at <https://elpais.com/internacional/2018/04/10/colombia/1523315848_436100.html>.

${ }^{17}$ Mimi Yagoub, "4 Troubling Takeaways From FARC Leader's Arrest," Insightcrime.org, April 12, 2018, available at $<$ https://www.insightcrime.org/news/analysis/4-troubling-takeaways-from-farc-leaders-arrest/>.

${ }^{18}$ Noticiascaracol.com, "Iván Márquez y 'el Paisa' Exigen Liberar a Santrich para Salvar Proceso de Paz", [Ivan Marquez and El Paisa Demand Liberation of Santrich to Save Peace Process], Noticiascaracol. com, April 23, 2018, available at $<$ https://noticias. caracoltv.com/el-acuerdo-final-paz-en-colombia/ ivan-marquez-y-el-paisa-exigen-liberar-santrich-para-salvar-proceso-de-paz-ie134>.

${ }^{19}$ Colprensa, "Autoridades están tras la pista de Iván Márquez y 'El Paisa' en zonas fronterizas" [Authorities are Following the Trail of Ivan Marquez and El Paisa in the Border Zones], Elpais.com.com, April 22, 2018, available at $<$ https://www.elpais.com.co/proceso-de-paz/ autoridades-estan-tras-la-pista-de-ivan-marquez-y-elpaisa-en-zonas-fronterizas.html>.

${ }^{20}$ Juan Forero and Kejal Vyas, "Colombia CocaineTrafficking Probe Poses Risk to Peace Accord," The Wall Street Journal, April 28, 2018 <https://www.wsj.com/ articles/colombia-cocaine-trafficking-probe-poses-riskto-peace-accord-1524937015>.

21 "Varios líderes de las FARC abandonaron zonas de reincorporación" [Several FARC Leaders Abandon the Reincorporation Zones], CNN Español, September 7, 2018, available at $<$ https://cnnespanol.cnn. com/2018/09/07/varios-lideres-de-las-farc-abandonaron-zonas-de-reincorporacion/>.

${ }^{22}$ Stiven Lopez, "Líderes de Farc abandonan espacios territoriales" [FARC Leaders Abandon Territorial Spaces], Lafm.com, September 6, 2018, available at $<$ https://www.lafm.com.co/colombia/ lideres-de-farc-abandonan-espacios-territoriales $>$.

23 "Los exguerrilleros de las FARC abandonan zonas de transición" [Ex Guerrillas of the FARC Abandon the Transition Zones], Hispantv.com., May 23, 2018, available at $<$ https://www.hispantv.com/noticias/colombia/377903/ farc-acuerdo-paz-zonas-transicion $>$.

24 "Second Kroc Institute Report Shows Steady Progress of Peace Accord Implementation in Colombia," Kroc Institute for International Peace Studies, August
9, 2018, available at <https://kroc.nd.edu/news-events/ news/second-kroc-institute-report-shows-steady-progress-of-peace-accord-implementation-in-colombia/> .

${ }^{25}$ Ibid.

26 "Segundo Informe sobre el estado efectivo de implementación del Acuerdo De Paz en Colombia" [Second Report on the Actual State of Implementation of the Peace Accord in Colombia], Kroc Institute for International Peace Studies, December 2016 $\neg$ May 2018, 7.

${ }^{27}$ Luisa Feline Freier and Nicolas Parent, "A South American Migration Crisis: Venezuelan Outflows Test Neighbors' Hospitality," Migration Policy Institute, July 18, 2018, available at <https:/www.migrationpolicy.org/ article/south-american-migration-crisis-venezuelan-outflows-test-neighbors-hospitality>.

28 "Venezuela: 3 Gráficos que Muestran la Enorme Dimensión del éxodo en los últimos años por culpa de la crisis" [Venezuela: 3 Graphs that Demonstrate the Enormous Size of the Exodus in the Last Years Caused by the Crisis], BBC.com, available at <https://www.bbc.com/ mundo/noticias-america-latina-45262411>.

${ }^{29}$ Ibid.

${ }^{30}$ Geoff Ramsey and Gimena Sánchez-Garzoli, "Responding to an Exodus-Venezuela's Migration and Refugee Crisis as Seen from the Colombian and Brazilian Borders," Reliefweb.int, July 26, 2018, available at $<$ https://reliefweb.int/report/colombia/ responding-exodus-venezuela-s-migration-and-refugee-crisis-seen-colombian-and- $0>$.

31 “QQué son los CLAP y cómo funcionan en Venezuela?"[What are the CLAP and how do they work in Venezuela?], CNN Español, September 5, 2017, available at $<$ https://cnnespanol.cnn.com/2017/09/05/ que-son-los-clap-y-como-funcionan-en-venezuela/> .

${ }^{32}$ CNN Español, “¿Por qué Rusia le está enviando tantas toneladas de trigo a Venezuela?" [Why is Russia Sending so Many Tons of Wheat to Venezuela?], CNN Español, September 4, 2017, available at $<$ https://cnnespanol.cnn.com/2017/09/04/ trigo-venezuela-rusia-cargamento-toneladas/ $>$.

${ }^{33}$ Leonardo Coutinho, Hugo Chávez: O Espectro [Hugo Chavez: the Spectre] (Sao Paulo: Vestigio, 2018), 47-78.

34 "Denuncian ante el Senado de EEUU que PDVSA es la principal estructura de lavado de dinero del régimen de Nicolás Maduro" [Accusations Before the US Senate that PDVSA is the Main Money Laundering Structure of the Nicolas Maduro Regime], Infoebae.com, September 12,2017 , available at <https://www.infobae.com/america/ venezuela/2017/09/12/denuncian-ante-el-senado-deeeuu-que-pdvsa-es-la-principal-estructura-de-lavadode-dinero-del-regimen-de-nicolas-maduro/>; see also 
"Crimen organizado utiliza PDVSA para lavar dinero de narcotráfico" [Organized Crime uses PDVSA to launder drug trafficking money], Venezuelaldia.com, August 1, 2018 available at <http://www.venezuelaaldia. com/2018/08/01/crimen-organizado-utiliza-pdvsa-lavar-dinero-narcotrafico/>.

35 "Chávez manda 10 batallones a la frontera"

[Chavez Sends 10 battalions to the Border], Eltiempo.com, March 3, 2008, available at <https:/www.eltiempo.com/ archivo/documento/MAM-2848752>.

${ }^{36}$ See "En 'revolución' hasta los soldados venezolanos buscan comida entre la basura" [In the Revolution Even the Venezuelan Soldiers are Looking for Food Among the Trash] YouTube video, posted online by Lapatilla Patillavideo on March 11, 2017, available at <https://www. youtube.com/watch? $v=$ wd9MUfBwEQw $>$.

${ }^{37}$ Noticias Caracol, "Con marchas en varias ciudades, oposición da la 'bienvenida' al presidente Duque" [With Marches in Several Cities the Opposition Welcomes President Duque], Noticias.caracoltv.com, August 7, 2018, available at $<$ https://noticias.caracoltv. com/politica/con-marchas-en-varias-ciudades-oposicion-da-la-bienvenida-al-presidente-duque-ie128>; "Estudiantes no quieren que la marcha sea aprovechada por políticos" [Students don't want the march to be taken advantage of by politicians], Eltiempo.com, December 10, 2018 <https://www.eltiempo.com/vida/educacion/ marcha-de-los-estudiantes-por-la-universidad-publica-279468>, Diario El Cauca, "Petro convoca a un paro nacional general en rechazo al IVA en la canasta familiar" [Petro Convokes a National Strike to Reject the Value Added Tax on Family Basic Needs], Diarioelcauca.com, November 12, 2018, available at <http://diariodelcauca. com.co/noticias/pol\%C3\%ADtica/petro-convoca-un-paro-nacional-general-en-rechazo-al-iva-e-479469>.

\section{Photos}

Page 82. Credit: Licensed under Creative Commons Attribution-ShareAlike 4.0 International License. Photo produced unaltered.

Page 84. Credit: Licensed under Creative Commons Attribution 2.0 Generic License. Photo unaltered.

Page 88. (Voice of America) 


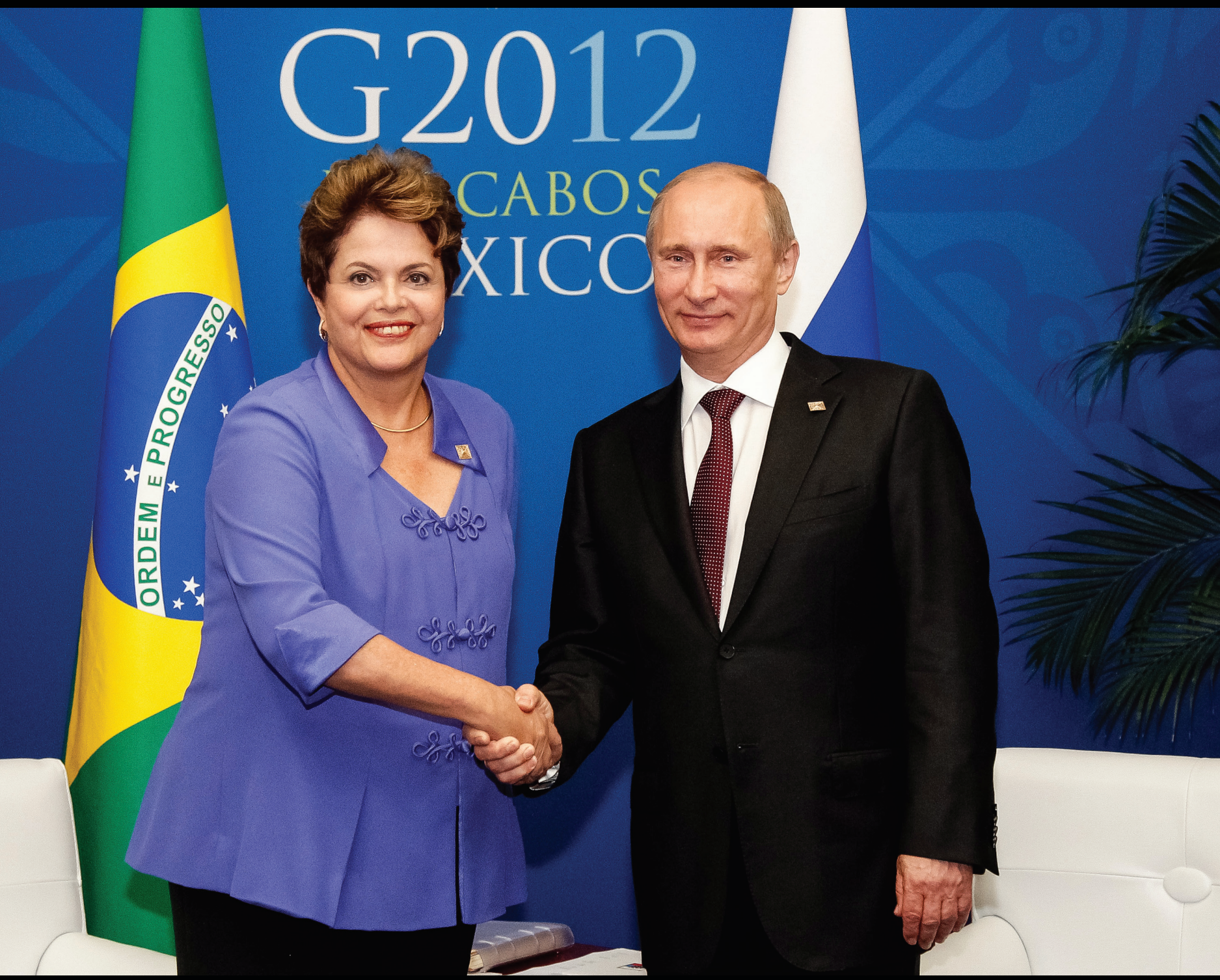

In 2012, Brazilian President Dilma Roussef and Russian President Vladimir Putin shake hands in Mexico. 


\section{Extra-regional Actors in Latin America: The United States is not the Only Game in Town}

By Douglas Farah and Kathryn Babineau

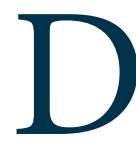

uring the past two centuries, the United States has enjoyed a largely unchallenged geopolitical, economic, and social influence in Latin America. However, in an increasingly multipolar world, Russia and China - and Iran to a lesser extent-have emerged to fill the vacuum left by diminished U.S. engagement in the region. Each with different interests, these three foreign actors exploit a growing, widespread disillusionment towards the United States. This regional disillusionment coupled with endemic corruption, violence, and erosion of the rule of law marks the conditions under which the extra-regional actors are engaging Latin America. All three actors have made significant gains-and suffered important setbacks - as they move aggressively to position themselves as alternatives to traditional U.S. hegemony in Latin America. Their success has not been total, nor has it gone completely unchallenged. However, their efforts are a new constant in the Western Hemisphere, as the United States increasingly pursues an agenda that is sharply divorced from the once-shared interests of the majority of the region's governments.

Russian President Vladimir Putin has made no effort to hide his desire to reestablish his country as a viable power player and competitor to U.S. influence in the region. Viewed through the lens of the Gerasimov Doctrine, this engagement is both rational from the Russian perspective and dangerous to the United States. So far, Russia has primarily focused its outreach efforts on allies in the Bolivarian Alliance, led by Venezuela and including Cuba, Nicaragua, Bolivia, El Salvador, and Suriname, all of whom share a strong anti-U.S. ideology with each possessing deeply criminalized governments. ${ }^{1}$ Often operating as a sort of "parasite state," the public outreach of the Putin regime in Latin America is designed to maximize impact at low cost. To date, this approach consists largely of weapons sales and donations, high level stateto-state visits, military and police training in areas of U.S. specialization such as counternarcotics, and financial assistance in avoiding the U.S.-based banking system. Within international forums, Russia has used its seat on the UN Security Council to protect Venezuela and Nicaragua from international sanctions, and has aggressively moved to open up financial operations-including banks and a crypto currency-to help its allies blunt the impact of U.S. and EU sanctions. The Russian presence, increasingly accompanied by Russian organized crime groups operating under the protection of the Russian state, is viewed by most

Mr. Douglas Farah is a visiting Senior Fellow with the Institute for International Strategic Studies at National Defense University and is President of IBI Consultants. A former Research Coordinator at IBI Consultants, Ms. Babineau is now a Ph.D candidate at the University of Virginia. 
U.S. stakeholders as presenting the biggest strategic challenge of the three countries discussed.

In comparison to Russia, China is primarily an economic competitor, actively seeking to expand its areas of influence globally. China's outreach has been much broader across Latin America where it has sought to build long-term economic relationships with any willing partner in the region. China's growing regional presence is focusing on trade and on increasing diplomatic ties at the expense of the Republic of China (Taiwan), while presenting itself as a global superpower capable of providing military training, business opportunities and unconditional foreign assistance in a more reliable, long-term way than the United States. Rather than wooing only the Bolivarian bloc and ideological allies, China engages across the region, recently convincing Panama and the Dominican Republic, key U.S. allies, and El Salvador to drop their diplomatic recognition of Taiwan. In exchange, both received large amounts of aid and promises of investment from the People's Republic of China (PRC).

Of the three external actors, Iran's revolutionary government has the smallest footprint in Latin America of the three countries and the most opaque agenda. Unlike Russia and China, Iran offers neither economic nor military support, but instead focuses on a narrower set of state and non-state actors through limited political outreach and illicit activities meant to further Iran's national interest and nuclear program. That influence diminished with the death of former Venezuelan president Hugo Chávez and the end of the presidency of Mahmoud Ahmadinejad in Iran, but may increase again contingent upon current developments.

Prior to the January 2016 implementation of the Joint Comprehensive Plan of Action (JCPOA) agreed to by Iran and the West, the Iranian government maintained an active network in Latin America to purchase dual use equipment for its nuclear program, and sought to build close partnerships with the Bolivarian bloc of nations that were belligerently anti-U.S. in tone and focus. ${ }^{2}$ Iran used the Bolivarian banking structures to evade sanctions, along with its primary allies: Venezuela, Bolivia, Ecuador, and Nicaragua. Attempts at a rapprochement with Argentina ended in 2016 with the end of the Kirchner government, and ties to Brazil in the past decade have fizzled.

Upon the initial implementation of the JCPOA, the visible Iranian presence in Latin America dropped significantly, although the infrastructure of the clandestine network remained in place. That network appears to be reactivating again in possible anticipation of the likely collapse of the JCPOA in the wake of the U.S. withdrawal from the pact. Closely tied to the Iranian government's formal structures are the Hezbollah-linked networks that engage in widespread criminal activities, such as contraband, money laundering, and drug trafficking needed to finance the Iranian proxy force.

\section{Impact of Changing Regional Dynamics}

Because Russia and Iran tied their Latin American agendas to the nations of the Bolivarian Alliance, the state of their relationships and relative importance in the region have mirrored that of their allies. During the ascendance of the Alliance in the early years of the $21^{\text {st }}$ century, Chávez, Putin, and Iran's president Mahmoud Ahmadinejad made several joint appearances to celebrate regional electoral victories. The three nations announced grand plans and joint projects that would cost billions of dollars and herald the dawn of the Alliance's motto: "Socialism for the $21^{\text {st }}$ Century." The strategic alliance produced an alternative to the United States on every front including economic aid, military training, equipping and doctrine, large-scale investment, and geopolitical orientation. The years since 2016, however, have seen a dramatic weakening of the Bolivarian Alliance. Powerful 


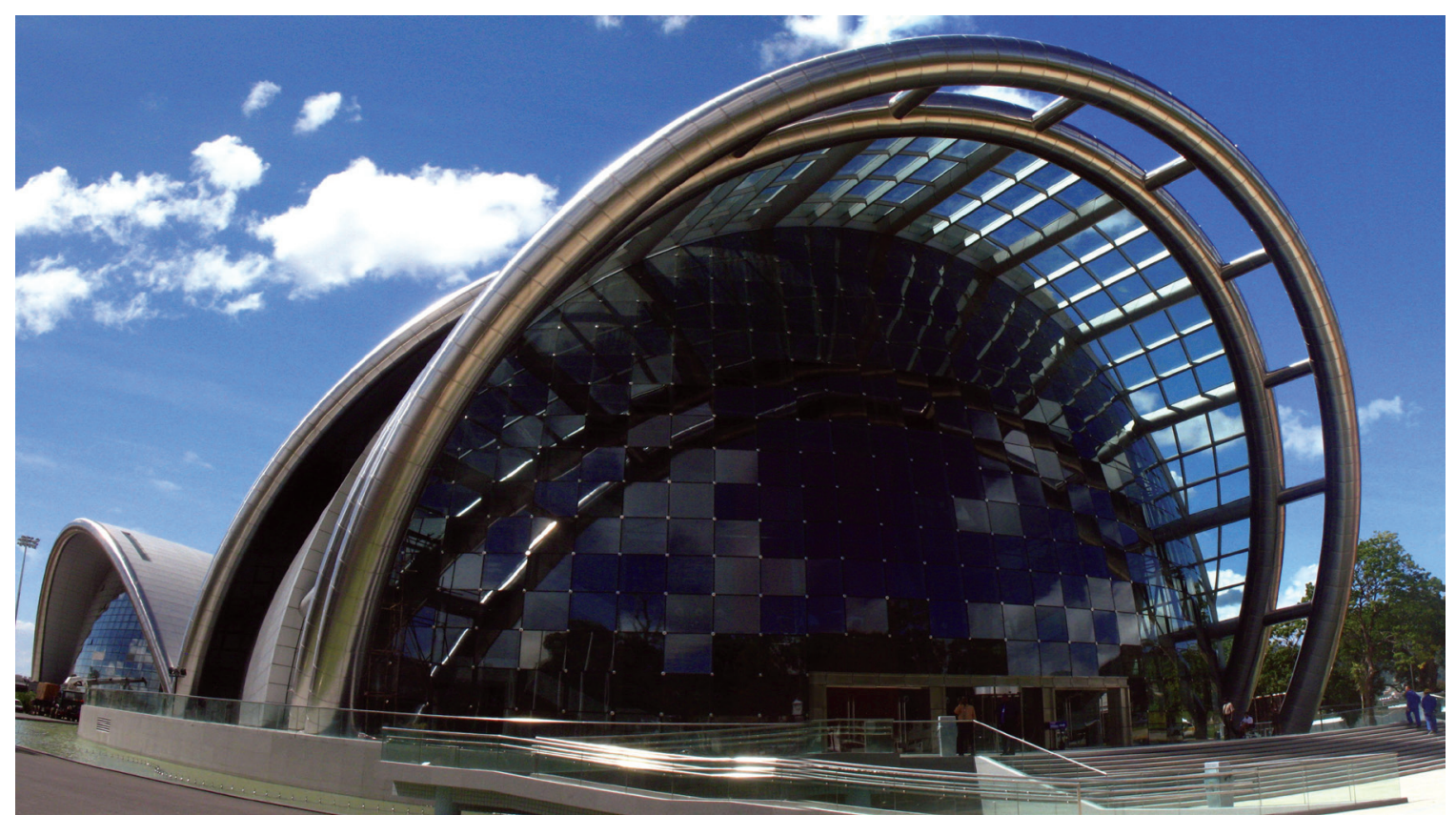

Port of Spain National Academy for the Performing Arts in Trinidad and Tobago, built by the Shanghai Construction Group. (Wikipedia/Belchman9006)

Alliance members-including Ecuador, Argentina, and Brazil-left the alliance, while other membersincluding Nicaragua and El Salvador-continue to experience major domestic challenges. As a result, Russia and in particular Iran, have far fewer willing partners in Latin America than even a few years ago.

China, playing a long game founded on pragmatism rather than ideology, has not seen the same downturn in influence and relationships as have Russia and Iran. By decoupling its economic and outreach agenda from an explicitly anti-U.S. message, China has been able to work across the region without significant opposition. While China has bailed out the Maduro government in Venezuela to keep it from default and has allowed Ecuador to accrue a massive debt, it has also maintained cordial ties with Colombia, Peru, and other U.S. allies. As noted above, since March 2017 Panama, El Salvador, and Dominican Republic dropped their historic recognition of Taiwan and recognized the PRC, leaving only 18 countries in the world that recognize Taiwan. ${ }^{3}$
The constant in the new regional dynamic is that the United States, less engaged in the region and no longer the sole external influence, is not driving ebbs and flows of the influence of the extra-regional actors in Latin America. Rather, it is a dynamic largely driven by the Latin American nations' perceived self-interests at any given time. The permanent presence of Russia, China, Iran, and others who are setting a proactive rather than reactive agenda means a new normal in Latin America.

\section{Growing Russian Influence in Latin America}

As Russia seeks to both expand and deepen its regional ties, the seminal Gerasimov Doctrine provides the framework for understanding the Russian strategy and tactics aimed at weakening U.S. influence, challenging U.S. dominance-military, economic, and political—and establishing a multipolar world order. As Commander of U.S Southern Command, Admiral Kurt W. Tidd outlined in his 
February 2018 Posture Statement to the U.S. Senate Armed Services Committee:

\section{Russia's increased role in our hemisphere is} particularly concerning, given its intelligence and cyber capabilities, intent to upend international stability and order, and discredit democratic institutions... Left unchecked, Russian access and placement could eventually transition from a regional spoiler to a critical threat to the U.S. homeland. ${ }^{4}$

This Russo-Bolivarian partnership has opened the door not only for political and economic influence but also for; the expansion of Russia's state-linked media to blanket the continent with an anti-U.S., pro-Russia propaganda via Sputnik News, Russia Today (RT TV), and other outlets; the installation of intelligence gathering platforms in close proximity to the United States, including numerous satellite tracking stations; and multiple commitments to nuclear expansion in the Hemisphere. In addition to the shared desire to minimize U.S. influence in the region, Russia's expanded outreach to the Bolivarian bloc provides a powerful friend on the UN Security Council capable of vetoing any efforts to hold them accountable for human rights violations or electoral fraud.

In addition to establishing strong traditional diplomatic relations, Russia is also now deeply engaged in activities helping its allies to; develop new cyber capabilities, including cyber-attacks and hacking; expand the sophistication and reach of surveillance equipment, mostly used against political enemies and journalists; participate in joint maneuvers and multiple military exercises; and purchase more sophisticated weapons systems that generate revenue and enhance Russian influence while diminishing that of the United States.

As part of this partnership, Russia has worked closely to prop up the Maduro regime in Venezuela both financially-through the advance purchase of increasingly scarce oil, coupled with debt forgiveness-and politically, by blocking sanctions and punitive measures in the United Nations and other international forums. The Putin government also enjoys a special rapport with its former revolutionary allies in the region, particularly those in Nicaragua and El Salvador. These nations have only grown in importance to Russia in recent years, particularly as the security and economic situation in Venezuela deteriorates and compromises its status as a reliable ally. In Nicaragua, President Daniel Ortega's long-standing ties with the former Soviet Union, forged during his days as the leader of the Marxist Sandinista National Liberation Front (FSLN), have allowed Russia to easily rekindle a relationship with his friendly government. In El Salvador, the governing Farabundo Marti National Liberation Front (FMLN) is the most recent reliable Russian partner in the region, based on the former Sovient Union's support for the FMLN's guerilla army during El Salvador's civil war. ${ }^{5}$

\section{The Gerasimov Doctrine in Latin America}

The strategic underpinning of the multi-faceted Russian activities in Latin America is the 2013 "Gerasimov Doctrine," put forward by General Valery Gerasimov, the Chief of Staff of the Armed Forces of Russia, a position that gives him operational control of Russian military intelligence (GRU). ${ }^{6}$ Gerasimov posited that Russia is in a state of permanent warfare, rather than facing a choice of war or peace. Within the continuum of blurred lines between war and peace is a new form of non-linear, or hybrid, warfare, in which all elements of the state are continually engaged, with greater or lesser emphasis. ${ }^{7}$

A recent NATO report unpacked this doctrine and the implications for Russia's new approach to warfare, and in particular hybrid warfare, noting:

Such a war, they argue, goes way beyond the frames of the traditional understanding of 
these wars. They include political intrigues, fights over resources and financial flows, and irreconcilable civilizational conflicts. On the battlefield in these wars, regular forces act alongside a number of new actors-irregular forces of rebels and fighters, criminal gangs, international terrorist networks, private military companies, and legions of foreign mercenaries, units of spetsnaz and intelligence formations from different countries, military contingents of peacekeepers from international organizations, and even non-governmental and humanitarian organizations and structures, representatives from printed and electronic mass media, volunteers, and activists from civil society. ${ }^{8}$

Viewed through the prism of this doctrine, Russia's activities in Latin America come into clearer focus. While the U.S. position remains preeminent-due to geographic proximity, cultural ties, and trade ties-Russia has advanced further and faster as a competitive adversary than is often understood.

A review of Russia's activities in the region shows that, despite limited resources, the Gerasimov Doctrine is being implemented through a policy that incorporates multiple elements of soft power, coupled with military training and hardware, to directly displace U.S. influence. This includes counternarcotics and disaster relief, as well as engagement in regional Latin American forums created by the Bolivarian Alliance for the express purpose of excluding the United States and Canada.

\section{Diverse Forms of Engagement}

Russia's desire to establish a stronger foothold in Latin America is evidenced by the constant highlevel government visits with its Latin American allies. In addition to more recent visits by senior officials - including to Ecuador and Surinamean analysis of visits by senior Russians to Latin American countries from 2015 to 2017, (including a vist from president Putin in November 2016 to attend the Asia-Pacific Economic Cooperation (APEC) summit in Peru), demonstrates a far greater level of engagement between high-level (the equivalent of an assistant secretary or above) officials of Latin American and Russian governments than that of the United States. ${ }^{9}$ As demonstrated in news articles and official government statements, Latin American officials from an estimated 20 countries visited Russia 44 times during those three years. ${ }^{10}$ Additionally, high-ranking Russian officials visited six Latin American countries on 11 occasions. This high-level presence decreased after 2017, with president Putin only visiting Latin America once in 2018, and even then only because the G20 summit was held in Argentina. ${ }^{11}$

Admittedly, U.S. engagement with the region extends far beyond highlevel or state visits, so this record does not suggest that Russian influence now exceeds that of the United States, but it does provide a useful point of reference. Equally important, experts widely agree that Russia's domestic political and economic troubles will likely prevent it from fully displacing the preeminent position that U.S. economic, security, and aid partnerships currently hold 
in the region. Nevertheless, these visits indicate that Russia is actively seeking partners in Latin America and is finding many countries in the region that are willing to consider such overtures.

Although still dwarfed by weapons sales from the United States and elsewhere, Russia has made significant inroads in recent years throughout Latin America, primarily with friendly countries, to expand its arms sales in the region. A recent NATO report noted the significant military purchases of Russian equipment by the Maduro regime, as well as President Ortega in Nicaragua:

Since 2005, Venezuela has purchased \$11 billion worth of equipment from Russia, including fighter jets, helicopters and rifles. Moscow provided loans to Caracas to help purchase the S-300VM anti-ballistic missile system to protect Venezuelan waters in 2013. The recent acquisition made Venezuela the second biggest importer of Russian arms between 2012 and 2015, after India. Lately, Russia also sent warships to the Caribbean to perform drug patrols. Colombians were outraged in October 2013, when two Russian supersonic bombers, capable of carrying nuclear warheads, flew from Venezuela to Nicaragua over San Andres, disputed territory between Colombia and Nicaragua. In March 2015, Venezuelan President Nicolás Maduro ordered the major military exercise "Bolivarian shield," with Russian participation, as a response to U.S. sanctions against seven Venezuelan officials. ${ }^{12}$

The Russian news agency TASS recently reported that since 2000, the Russian arms exporter Rosoboronexport has sold $\$ 10$ billion in weaponry and military equipment to Latin American nations. ${ }^{13}$ The company is working with Argentina, Brazil, Colombia, Mexico, and Peru to broker deals for both ground and air equipment, in particular Ural trucks and motor vehicles. In addition to Rosoboronexport, the Russian companies Rostec and Irkut Aircraft Corporation are also known to be operating in the region, including attending military expositions in Latin America.

Although producing few tangible results, Russia has also publicly expressed its willingness to partner on nuclear projects in Latin America. In October 2016, Russia and Paraguay announced a new Pacific nuclear energy partnership, which begins a new wave of investments and technology sharing between the two countries. ${ }^{14}$ Similarly, in January 2018 Argentina announced a recent memorandum of understanding with Russia's state nuclear corporation Rosatom, which covered uranium exploration in Argentina as well as assistance in the construction of nuclear power plants. ${ }^{15}$

Russia has also made a concerted effort to deepen its partnerships with Bolivia, recently announcing that it would assist Bolivia in building a "nuclear center to research radiation technologies applied in agriculture, medicine and various industries." ${ }^{\prime 16}$ After announcing that he had met with a number of Russian officials, and was considering additional partnerships in a number of other areasincluding lithium production-Bolivian President Evo Morales, who recently visited Russia, commented warmly on the growing Russian presence in the region. ${ }^{17}$

\section{Organized Crime and Money Laundering Structures}

In his discussion of Russian foreign policy in June 2018, Admiral Tidd noted that the arrival of a Russian diplomatic presence anywhere in the world is almost immediately followed by the presence of Russian organized crime, which often allies itself with existing transnational criminal networks. ${ }^{18}$ These criminal activities are often sanctioned by the Russian government and are considered among the tools of statecraft under the Gerasimov Doctrine. 
There have been several cases in Latin America recently where the Russian state and transnational criminal networks have merged to the mutual benefit and profit of both.

Perhaps the most notorious case of such collaboration came to light in February 2018, when Argentine authorities seized approximately 400 kilograms of cocaine destined for Russia, which they discovered housed in an annex of the Russian embassy. Former Russian diplomatic officials, as well as Argentine police, were among those arrested as part of the operation, which aimed to move the cocaine in diplomatic luggage to Moscow. ${ }^{19}$ The head of the criminal network identified as "Mr. K," Andrey Kovalchuck, was reported to have a relationship with the Russian ambassador in Argentina. ${ }^{20} \mathrm{He}$ was arrested in Germany in March $2018 .{ }^{21}$ Testimony from one of the men arrested in the case, Ali Abyanov, indicated that the Russian embassy in Uruguay was heavily involved in the drug smuggling operation, which Abyanov said has been running for years. ${ }^{22}$

\section{Propping up Venezuela}

Russia has continued to serve as a staunch supporter of the Venezuelan regime, even announcing before the completion of vote counting that the May 2018 presidential elections-widely considered to be fraudulent and undemocratic by most of the international community - were valid. ${ }^{23}$ Experts note that the Maduro government, alienated from much of the regional and international community, views its relationship with Russia as symbiotic, as it reaches out to autocratic partners for survival.
As oil rich nations that currently have great difficulty accessing global financial systems, primarily as the result of effective sanction regimes in the West, Russia and Venezuela have grown their partnership in recent years. And while other nations and multinational companies look to cut their losses in Venezuela, Russian oil giant Rosneft continues to invest heavily. According to recent reporting, Rosneft is swapping debt for 100 percent control of the largest Venezuelan gas reserves; furthermore, as Russia bails out the struggling Venezuelan state-owned oil and natural gas company, Petróleos de Venezuela, S.A. (PDVSA), Rosneft's agreements allow them to export 100 percent of what they produce. According to oil industry expert Francisco Monaldi, Rosneft produces around 140,000 barrels per day and is one of the three largest oil companies in the country. Russia has loaned Venezuela an additional $\$ 5$ billion and as part of these deals, Rosneft received nearly 50 percent ownership of the U.S. CITGO refinery as collateral for further debt refinancing. ${ }^{24}$

Additionally, President Maduro received Russian assistance in the development of an official Venezuelan cryptocurrency-known as the petroto avoid the financial constraints of U.S. sanctions. ${ }^{25}$ Venzuela followed the late 2017 creation of the petro with a January 2018 announcement by Maduro that 100 million "tokens" would be released in the initial sale of the petro for which-given the oil backing of the currency - analysts calculated the total value to be about $\$ 6$ billion. ${ }^{26}$ And yet, while it relies on the value of Venezuelan oil, the Venezuelan government has indicated that the petro cannot actually be 
exchanged for barrels. The petro, designed with the help of a Russian cyber expert Fedor Bogorodsky (living in Uruguay), was officially offered for presale beginning in February 2018. Between February $15^{\text {th }}$ and March $15^{\text {th }}, 38$ million of 100 million tokens were auctioned with financial analysts estimating the total sale at $\$ 1.3$ billion. ${ }^{27}$

In response to the petro, in March the United States officially banned:

all transactions related to, provision of financing for, and other dealings in, by a United States person or within the United States, any digital currency, digital coin, or digital token [issued by the Venezuelan government since January 9]. ${ }^{28}$

Only one little-known Russian bank, Evrofinance Mosnarbank, handles the currency. Evrofinance is comprised of a consortium of sanctioned Russian banks (50.1 percent) and a sanctioned Venezuelan state entity (49.9 percent). ${ }^{29}$

\section{Russian Media Influence}

During the past three years, Russia has moved aggressively to expand its state media presence in Latin America and has, with each passing year, grown more sophisticated in the Spanish-language services it offers on multi-media platforms. These networks have quickly expanded their reach across the Hemisphere. A recent report succinctly outlined the overall aim of these efforts, which is to encourage pro-Russian sentiment throughout the region:

Moscow uses RT, other official media, social networks, and culture to change the perception that the region, including Argentina, has of Russia. Currently its image is of a country that is a continuation of the Soviet Union, which was the embodiment of hard, militarized power. Looking to the future, Moscow's goal is to promote a more culturally and technologically inclusive image, which is seen as key to being perceived as a modern, preeminent power, not just a strategic one. ${ }^{30}$

The two primary vehicles are RT Español and Sputnik Mundo, both closely tied to the Russian state and both carrying exclusively pro-Russia, and antiU.S. messages. Much of the news on the websites of both outlets relates to Latin America through the lens of Russian "value-added," including the aid and assistance the Putin regime can offer in the region, primarily to the nations comprising the Alianza Bolivariana para los Pueblos de Nuestra América (ALBA). ${ }^{31}$ These Russian state media outlets are reproduced and linked back and forth to a large network of websites and programming run by the Bolivarian Alliance and their proxies across the Hemisphere, greatly amplifying the Russian media reach in Latin America.

\section{China's Long-Term, Economics-First Approach}

China's growing influence in Latin America looms large, second only to its influence and commercial exchanges with the United States. Primarily, although not exclusively economic in nature, China's activities in the region have been extensively documented in other academic and policy analysis. ${ }^{32}$ While China has certainly not yet replaced the United States in the Western Hemisphere, the gap continues to close at a significant pace. The United States has far larger foreign direct investment in Latin America than does China, although exact comparisons are not possible given that most of the Chinese enterprises are tied to the state. In addition, according to one analysis, Latin America constitutes almost 25 percent of total U.S. trade; and its producers export three times more to Latin America than to China." ${ }^{33}$

Chinese influence is perhaps best demonstrated by official high-level Chinese visits to Latin American countries. The PRC's top three officials dealing with 
foreign relations-President Xi Jinping, Foreign Minister Wang Yi, and Prime Minister Li Keqiangmade a combined 29 visits to Latin America between 2015-18. Moreover, almost half of these visits occurred in 2018, indicating an accelerating pace of Chinese interest and engagement in the Hemisphere. In the last two months of 2018 the presidents of El Salvador, Panama, the Dominican Republic, and Cuba all visited China as well. There were dozens of other visits by senior Chinese officials (the equivalent of an assistant secretary or above ) to Latin America and Latin American officials to China. ${ }^{34}$ Thus while Russian presence-at least high-level, public visitshas decreased during the past two years, Chinese visits are increasingly common.

As Chinese President Xi said when welcoming Argentine President Mauricio Macri to Beijing in May 2017, "Latin America is the natural extension of the $21^{\text {st }}$ century Maritime Silk Road." ${ }^{35}$ While seeking to extend the new Silk Road China, like Russia in recent years, has been attempting to replicate programs that have long propagated American influence, such as military-to-military training programs where the United States has long-held sway. Indeed, China now offers similar programs, and often outperforms what the United States can offer. According to U.S. military officials in 2015, China for the first time trained more Latin American military officers than the United States, and the difference has grown every year since. Participants in Chinese military exchanges said that in addition to more opportunities in Chinese programs than U.S. programs, China offers several other advantages. Participants travel business class, stay in 5-star hotels, and often all expenses are paid during their time in China. In contrast, the United States generally offers economy class travel, non-luxury accommodations, and non- paid tourism excursions. ${ }^{36}$

Another key priority for China is to consolidate its position as the sole legitimate Chinese government in the Hemisphere. As a result, China has made significant efforts to woo Taiwan's long-time allies in the region to recognize the Beijing government. The efforts have yielded results, with Panama switching its recognition in June 2017 and becoming the first country in Latin America to join China's muchtouted One Belt One Road (OBOR) initiative. ${ }^{37}$ The Dominican Republic shifted recognition in May 2018 and El Salvador followed suit in August, leaving only nine nations in the Hemisphere-mostly Caribbean islands-that still recognize Taiwan. ${ }^{38}$

As R. Evan Ellis noted in June 2017, China's policy toward Latin America is unique in its opaqueness; in contrast to Russia (and the Soviet Union before that), China's discussion of engagement abroad solely on the basis of mutually beneficial investment opportunities belies hidden strategic goals:

In contrast to the Cold War struggle between the U.S. and the Soviet Union, the $P R C$ does not explicitly seek to impose a particular model of governance or economic organization on the world. Yet that does not mean that China's engagement is benign or without significant adverse consequences. With self-interest that is understandable but stunning in its global implications, the PRC is seeking to leverage its growing economic weight and capabilities, through a combination of statecraft, trade, loans, investment, and other forms of engagement, to structure a world order in which global commercial flows, political relationships, and institutions support expanding China's wealth and power. ${ }^{39}$

China is also moving aggressively to use its growing economic clout to shape hemispheric events. Last year, for the first time ever, China was granted observer status at the Summit of the Americas held in Lima, Peru in April. It was also the first summit the U.S. President did not attend, offering a stark reminder of the shifting regional priorities for both nations. As one observer noted, 
"This is particularly significant at a time when China-LAC trade has reached almost historic heights - in 2017 it totaled $\$ 266$ billion - and China has become the top trading partner for a number of countries in the region, including some of the biggest economies, like Brazil, Chile, and Peru, as well as smaller ones like Uruguay." ${ }^{30}$ In addition, according to the Brookings Institution, by 2017 China had invested almost $\$ 250$ billion in Latin America during the previous decade, making it a critical player in the region's economic outlook. ${ }^{41}$ As the Chinese investments, trade, and training grow, according to fiscal year (FY) 2018 budget requests, the Trump Administration requested $\$ 1.1$ billion for Latin America and the Caribbean in foreign assistance, an estimated $\$ 600$ million decrease from FY 2017 aid numbers. ${ }^{42}$ This includes both economic assistance and a number of security assistance programs managed by the U.S. State Department. ${ }^{43}$

Furthermore, in his discussion of Beijing's foreign policy, Ellis argues that, given how China does not ascribe to the key tenants of the liberal world order, a world in which Chinese influence is on the rise likely represents a threat to "the rights and liberties of the rest of the world," goals that the United States has actively sought to further through its foreign policy. ${ }^{44}$ This pragmatic approach, consistent with the pledge of non-interference in the affairs of other countries and the desire to gain hemispheric leverage, is largely devoid of considerations for issues such as environmental degradation, rule of law, functioning democratic institutions, and internal repression. This helps explain China's willingness to lend massive amounts of money to the Maduro regime in Venezuela. The debt stood at $\$ 62$ billion in mid-2017 and grew by at least $\$ 5$ billion more in early 2018 despite the deteriorating economic, political and human rights situation..$^{45}$ Much of the debt is to be repaid with oil, and the infusions of Chinese cash, despite Venezuela falling continually far behind on its oil shipments, has been a key factor in keeping the Maduro regime from debt default and complete collapse. It is worth noting that the price of trying to exchange debt for energy security could be very high, given that the opposition in Venezuela has promised to tear up the contracts with the Chinese. In this scenario, China could end up with all debt and no oil.

\section{Chinese Media: Reinforcing the Long Game}

Like its Russian counterpart, in Latin America the Chinese leadership spends a great deal of effort and resources on shaping the narrative of China's expanding presence through state-controlled media. Unlike the Russians, and increasingly less like the United States, the Chinese government hosts annual meetings between Latin America media leaders and Chinese leaders, usually with expense paid trips to Beijing. A recent report noted:

In true digital age fashion, Chinese outlets in Latin America have skipped over traditional print media in favor of virtual platforms, which host content tailored to local audiences. Though slightly less up-to-date than their Chinese-language versions, newspapers Xinhua and People's Daily produce daily Spanish and Portuguese-language content, as does China Radio International (CRI). China Central Television (CCTV), meanwhile, boasts a 24-hour channel, CGTN Spanish, which is available online, free of charge. Even the magazine China Today, which remains one of the few examples of Chinese print media in Latin America, maintains not one, but two Spanish-language websites, in addition to its two print publications in Mexico and Peru. Nearly all of these outlets have Spanish-language accounts on social media that are banned in China, including Facebook, Twitter, and YouTube. ${ }^{46}$

Xinhua, the official state-run press agency of China, has 21 bureaus in 19 Latin American countries, along 
with 200 media subscribers (who get the new feed for free or at greatly discounted prices) and 200 non-media subscribers, including government ministries across the region. The purpose of the expansion, according to Cai Mingzhao, the director of Xinhua, is to use the agency's 50 years' experience in the region to "play a larger role in shaping a China, Latin America and Caribbean community of common destiny." ${ }^{47}$

That destiny may ultimately prove not as rosy as it currently appears to many in Latin America. A recent analysis by the C4ADS research group indicates that in the case of the Indo-Pacific, China's OBOR initiative may provide the perfect cover for China's strategic expansion of the international security infrastructure. They argue:

The BRI [Belt and Road Initiative], China's guiding foreign policy doctrine and one of the most ambitious economic initiatives in modern history, is portrayed by Chinese leaders as creating win-win economic development for all nations. Yet, some states question whether China's infrastructure investments are driven by strategic interests... The authors find that Chinese analysts unofficially discussing port investments routinely prioritize China's national security interests over the objective of mutually beneficial economic development, contradicting the position of official policy documents. Chinese analysts argue that the BRI's Maritime Silk Road component can help ensure Beijing's access to vital sea lines of communication. Port investments are viewed as vehicles with which China can cultivate political influence to constrain recipient countries and build dual-use infrastructure to facilitate Beijing's long-range naval operations. ${ }^{48}$

Studies like this one help to show the true nature of Chinese investment, and time will only tell how this model will also be applied to Latin America. As engagement with the region deepens, it is undoubtedly possible that China's economic program gives way to a more overt national security agenda, as appears to be the case in other areas of the world.

\section{Iran in Latin America: A Plan of Proximity}

Since the triumph of the Iranian Revolution in 1979, the Islamic republic has viewed Latin America as a fertile field for expansion, both in political and religious influence and in building a nuclear arsenal. Its first primary theater of expansion was Argentina, and included signing a nuclear agreement that, when abrogated by Argentina at the request of the United States, led to the 1994 Iranian-sponsored attack on a Jewish AMIA center in Buenos Aires. The attack left 85 people dead and more than 100 wounded. ${ }^{49}$ In 2015, on the eve of prosecutor Alberto Nisman's presentation of an indictment against Argentina's then President Cristina Fernández de Kirchneron charges of secretly reopening talks with Iran regarding a nuclear program-he was murdered inside his apartment. There are serious indicators that the murderers were directly tied to the Iranian state. ${ }^{50}$ In other countries throughout the region, Iran has made use of Latin America's proximity to the United States as a staging ground for attacks. For example, public trial records show that Iran, operating through Guyana, was behind the 2007 attempted attack on JFK airport in New York City. ${ }^{51}$ Furthermore, the U.S. Government officially blamed senior Iranian government officials, operating in Mexico of funding a failed 2011 attempt to assassinate the Saudi ambassador in Washington, D.C. ${ }^{52}$

Iran has relied on the Bolivarian Alliance and its staunchest allies to make inroads across the region, largely focused on the expansion of its diplomatic presence and Shi'a Islamist cultural centers within the safe confines of the Bolivarian Alliance member countries. By 2015, Iran or its proxy Hezbollah controlled some 80 cultural centers 
across the hemisphere, many of them carrying out activities with radical populist groups that share the same anti-American agenda. Radical imams such as Abdul Karim Paz, Suhail Assad and others traveled the region visiting the cultural centers, particularly those in San Salvador, El Salvador and Iquique, Chile. Oscar Rodriguez, a Salvadoran Islamic convert who changed his name to Mustafa al Salvatori, spent nine years studying in Iran and returned to the region in 2016 as a representative of Iran in Central America.

These cultural activities, however, have recently diminished significantly. With the Bolivarian Alliance in retreat and Iran under intense internal and international pressure because of its involvement in hot wars in Syria and Afghanistan, Iran's standing in the region has weakened. As a result, visits by Irananian public officials to the region have all but ended.

At its height in 2011, the embrace of the Iranian and the Bolivarian revolutions demonstrated striking similarities in the language and strategic framework used to define themselves. Both revolutions, the Iranian and the Bolivarian, used identical words to describe their struggle in favor of the "oppressed" and against "oppressor states," and both defined the United States as the fulcrum of oppression. Not only were the words similar, but the two revolutions found a common point of departure for their visions of the need to attack the United States, based on their individual interpretations of the 1979 Iranian revolution. For the Iranians, the revolution was an act of Allah striking the infidel the United States; for the Bolivarian Alliance, the revolution was a lesson in successful asymmetrical warfare. This analysis by the Bolivarian leaders led to the adoption of a doctrine of asymmetrical warfare, which embraces the use of weapons of mass destruction against the United States and the belief that both revolutions face a common enemy in the United States. ${ }^{53}$

As their relationship grew, the Iranians and the Bolivarians turned their shared ideology into partnership. Desperate for access to the U.S. banking structure as international sanctions kicked in, in 2012 the Iranian government successfully negotiated with then Ecuadoran President Rafael Correa to establish a clandestine banking relationship between an Ecuadoran dollarized bank and a consortium of sanctioned Iranian financial institutions. The plan called for encrypted communications between the banking structures in both nations, with the decryption key to be held by the Iranian ambassador in Quito, Ecuador. ${ }^{54}$ Given that the highest priority of the Iranian government in rebuilding its Latin American network was primarily focused on acquiring dual-use technology, access to the Western banking system and revenue streams from illicit state-to-state activities, it was narrowly focused both conceptually and geographically.

When the JCPOA was adopted, the need for most of the services acquired from the Bolivarian Alliance diminished. Iran once again had access to the global banking structure, the acquisition of most technology on the open market, and oil sales to generate revenue.

This is the most likely explanation for the rapid disappearance of the visible activity of the Iranian network in most of Latin America. Once vibrant cultural centers, like that in San Salvador, have gone quiet and are no longer hosting the large pro-Iranian events that once filled their calendars. The recruitment of dozens of students from each country in the Hemisphere to attend seminars and training in Iran, begun around 2009 , has largely ceased. Visits by senior Iranian officials to the hemisphere, frequent under then Iranian president Ahmadinejad, are now few and far between, and almost none of the joint projects announced (a bicycle factory in Venezuela, a dairy processing plant in Nicaragua, and dozens of others) have come to fruition.

Given the decision of the Trump Administration to withdraw from the JCPOA in May 2018, it is likely that the Iranian network and the networks of its proxies like Hezbollah will again 
become more active, as some of the same necessities for the survival of the Iranian regime will reappear. What is unclear is how much support the Iranian government can still garner from what is left of the Bolivarian Alliance. With Ecuador having withdrawn its banking support and unlikely to reinstate it, Venezuela and Nicaragua in existential crisis and El Salvador weakened, there are few allies left to come to the rescue. Nevertheless, Iran began building its clandestine network in the early 1980s and it has proved resilient and durable in less fertile terrain than currently exists. This suggests that Iran will remain active around the margins where necessary and in a more active and visible form where possible.

\section{Conclusion}

As Admiral Tidd noted in June, the United States "is no longer the only game in town" in Latin America, and its adversaries are engaged in "indirect assaults" on U.S. interests to broaden the competitive spaces in the hemisphere. ${ }^{55}$ While USSOUTHCOM views threat networks as the biggest strategic challenge in its AOR, these threat networks are growing with the expanding influence of the three extra regional actors.

In a multipolar world, jockeying for a geopolitical edge is not uncommon nor necessarily a threat. However, in the case of Latin America, none of the primary competitors with the U.S. shares any of its fundamental values of fostering democracy and rule of law, nor strategic objectives such as drug interdiction, halting migrant flows, or building a mutually beneficial regional security structure. In fact, each of the three extra-regional actors discussed sees the United States as an enemy and views diminishing U.S. influence and weakening its standing as strategic imperatives. In the cases of Russia and Iran, friendships with the Bolivarian Alliance are built on a foundation of hatred toward the United States and the fusion of highly criminalized states with transnational organized crime groups, often wielded as instruments of statecraft. China's interests are primarily pragmatic economic and geopolitical strategic concerns. While none of the three currently represent a clear strategic military challenge to the United States, all have positioned themselves to be able to grow beyond economic and political competition to something much more dangerous if left unchecked. This is particularly true for Russia, which is quietly building cyber and military capacities with the intention of targeting the United States when possible.

As the Bolivarian Alliance is weakened, the United States has yet to successfully put together an active coalition to reclaim the space seized by Russia, nor has it succeeded in creating a community of interest to keep Iran from reactivating its clandestine networks in the hemisphere. Given the current economic and budgetary realities in the United States, there will be little effort to challenge China's expanding economic reach in the Hemisphere.

Most countries outside the Bolivarian Alliance would prefer to deal with the United States rather than its adversaries. Furthermore, most of the Bolivarian Alliance nations are in crisis and offer relatively few competitive advantages to the United States' extra-regional adversaries at this time. But U.S. disengagement in the region, coupled with the emergence of well-funded alternatives, has given many potential allies a reason to hedge their bets. The growing anti-U.S. narrative, fed by Russian disinformation, Chinese state media, and Iranian websites and outreach linked to a vast network of cyber allies is also taking its toll on how the United States is perceived.

The current trajectory in the Hemisphere cannot be altered solely with displays of military power or occasional threats and sanctions against bad actors. A genuine whole-of-government strategic approach, including diplomatic, economic, intelligence, and military components, is the only option to shrink the operational space of adversaries intent on diminishing the influence and effectiveness of the United States in Latin America. PRISM 


\section{Notes}

${ }^{1}$ The Bolivarian Alliance, officially La Alianza Bolivariana Para los Pueblos de Nuestra América (Bolivarian Alliance for the Peoples of Our America) was created in 2004 by Venezuela and Cuba, and has grown to include Bolivia, Ecuador, Nicaragua, Suriname and several small Caribbean island nations. For a closer look at criminalized states in the Bolivarian Alliance see: Douglas Farah, "Transnational Organized Crime, Terrorism and Criminalized States: An Emerging Tier-One Security Challenge," U.S. Army War College, Strategic Studies Institute, Carlisle, PA, August 2012.

${ }^{2}$ The JCPOA, negotiated by Iran with the United States, Russia, China, United Kingdom, Germany, France, and the European Union, committed Iran to stop development of its nuclear weapons program in exchange for a lifting of international economic sanctions. The United States unilaterally withdrew from the agreement in May 2018.

${ }^{3}$ Austin Ramzy, "Taiwan's Diplomatic Isolation Increases as Dominican Republic Recognizes China," The New York Times, May 1, 2018.

${ }^{4}$ Hearing to Receive Testimony on the United States Northern Command and Southern Command in Review of the Defense Authorization Request for 2019 and the Future Years Defense Program Before the U.S. Senate Armed Services Committee, 115th Congress (2018), February 15, 2018 (Statement of Admiral Kurt W. Tidd, Commander, United States Southern Command), 6-7.

${ }^{5}$ The FSLN was first a Marxist guerilla army responsible for the overthrow of the Somoza dictatorship. President Ortega's FSLN first governed Nicaragua from 1979-90, and then again from 2007-present.

${ }^{6}$ For a look at the significance and power of the Russian chief of staff see: Charles K. Bartles, "Getting Gerasimov Right," Military Review, January-February 2016, available at $<$ http://usacac. army.mil/CAC2/MilitaryReview/Archives/English/ MilitaryReview_20160228_art009.pdf >.

${ }^{7}$ Full English translation of General Gerasimov's article is available at $<$ https://inmoscowsshadows.wordpress.com/2014/07/06/ the-gerasimov-doctrine-and-russian-non-linear-war/>.

${ }^{8}$ Gudrun Persson, "The War of the Future: A Conceptual Framework and Practical Conclusions Essay on Strategic Thought," NATO Defense College Russian Studies Series 3/17 (July 2017), 3, available at < http://www.ndc.nato.int/news/news.php?icode=1078>. There is not universal agreement that that Gerasimov was expressing a formal military doctrine, as in his initial work he was discussing how Russia viewed the Arab Spring and other "color" movements. However,
Gerasimov, who has visited Latin America, offers a useful prism through which to view Russian behavior in the hemisphere.See: Mark Galeotti, "I'm Sorry for Creating the 'Gerasimov Doctrine," Foreign Policy, March 5, 2018, available at $<$ https://foreignpolicy.com/2018/03/05/ im-sorry-for-creating-the-gerasimov-doctrine/>.

9 "Ecuador Highlights Close, Multidimensional Relationship with Russia," Latin American Herald Tribune, May 17, 2018, available at <http://www.laht.com/ article.asp?ArticleId=2456769\&CategoryId=14089>; and Ray Chickrie, "Suriname Pivots towards Russia; Foreign Minister to Visit Moscow," Caribbean News Now, October 17,2017 , available at $<$ https://wp.caribbeannewsnow. com/2017/10/17/suriname-pivots-towards-russia-foreign-minister-visit-moscow/>.

${ }^{10}$ The data collection for high-level visits by senior officials was conducted through open-source data scraping. This includes government press releases, multilateral meeting rosters (like for the G20 summit) and local and national news reviews of major newspapers in China, Russia, the United States, and all Latin American countries.

11 "Putin Lands in Argentina for G20."

Reuters, November 30, 2018, available at $<$ https://www.reuters.com/video/2018/11/30/ putin-lands-in-argentina-for-g20?videoId $=486977218>$.

${ }^{12}$ Robert Helbig and Guillaume Lasconjarias, "Winning Peace and Exporting Stability: Colombia as NATO's next Global Partner?” NATO Defense College Research Paper no. 138 (May 2017), 13.

13 "Russia Delivers Modern Weaponry Worth Over \$10 Billion to Latin America," Russia Beyond the Headlines, April 28, 2017, available at $<$ https://www.rbth. com/news/2017/04/28/russia-delivers-modern-weaponryworth-over-10-billion-to-latin-america_752344>.

14 "Rusia y Paraguay Cooperán en el uso pacífico de la energía nuclear [Russia and Paraguay Cooperate in the Peaceful use of Nuclear Energy]," TRT, October 8, 2016, available at <http://www.trt.net.tr/espanol/ ciencia-y-tecnologia/2016/10/18/rusia-y-paraguay-cooperaran-en-el-uso-pacifico-de-la-energia-nuclear-592135> .

15 "Russia to Assist Argentina in Uranium Mining," World Nuclear News, January 24, 2018, available at < http://world-nuclear-news.org/UF-Russia-to-assistArgentina-in-uranium-mining-2401184.html>.

16 "Moscow to Assist Bolivia Building Nuclear Research Center-Russian Envoy," Sputnik News, June 23, 2018, available at <https://sputniknews.com/ latam/201806231065689341-bolivia-russia-nuclear-research-center/>.

17 "Moscow to Assist Bolivia Building Nuclear Research Center-Russian Envoy," Defence Monitor Worldwide, June 25, 2018, accessed via Nexis. 
${ }^{18}$ Admiral Kurt W. Tidd, "Prepared Remarks: Adm. Tidd at Center for Naval Analysis," Center for Naval Analysis,June 7, 2018, available on the U.S. Southern Command website <http://www.southcom.mil/Media/ Speeches-Transcripts/Article/1543839/prepared-remarksadm-tidd-at-center-for-naval-analyses/>.

${ }^{19}$ Angelika Albaladejo, "Cocaine Ring in Russia's Argentina Embassy Dismantled," InSight Crime, February 23, 2018, available at <https://www.insightcrime.org/news/ brief/cocaine-ring-russia-embassy-argentina-dismantled>.

${ }^{20}$ Mariano Gaik Aldrovandi, "Narcovalijas Rusas: en las Escuchas los Traficantes Mencionan al Embajador." Clarin, February 24, 2018, available at <https://www. clarin.com/policiales/narcovalijas-rusas-escuchas-traficantes-mencionan-embajador_0_S1DzcOkuf.html>.

${ }^{21}$ Andrew Roth and Uki Goni, "Senor K: Russia and Argentina Split Over Mysterious Drug Smuggling Case," The Guardian, March 3, 2018.

22 "Russian Embassy in Uruguay Says Information Regarding its Involvement in Argentinian Cocaine Crisis Is Bogus," Crime Russia, March 3, 2018, available at $<$ https://crimerussia.com/drugmafia/ posolstvo-rossii-vurugvae-nazvalo-vymyslom-informatsiyu-o-svyazi-skokainovym-skandalom/>.

23 "Russia Considers Venezuelan Presidential Polls Valid," TASS, May 21, 2018, available at < http://tass.com/ politics/1005355>.

${ }^{24}$ Alexandra Ulmer, "Exclusive: U.S. Investors Seek to Acquire Russia's Rosneft Lien in Citgo," Reuters, February 26, 2018, available at $<$ https:// www.reuters.com/article/us-usa-oil-citgo-exclusive/ exclusive-u-s-investors-seek-to-acquire-russias-rosneftlien-in-citgo-idUSKCN1GA2J4>.

${ }^{25}$ Simon Shuster, "Exclusive: Russia Secretly Helped Venezuela Launch a Cryptocurrency to Evade U.S. Sanctions," Time Magazine, March 20, 2018, available at <http://time.com/5206835/ exclusive-russia-petro-venezuela-cryptocurrency/>.

26 "Venezuela Says Will Pre-Sell 'Petro' Cryptocurrency on Feb.," CNBC, January 31, 2018, available at <https://www. cnbc.com/2018/01/31/venezuela-says-will-pre-sell-petro-cryptocurrency-on-feb-20.html>.

${ }^{27}$ Emiliya Atanasova, "The Petro: Venezuela Woos Qatar as Maduro Hangs Onto Crypto Dream," Cryptovest, January 19, 2018, available at <https:// cryptovest.com/news/the-petro-venezuela-woos-qatar-as-maduro-hangs-onto-crypto-dream/>.

${ }^{28}$ Gideon Long, "US Bans Trade in Venezuela's Digital Currency," Financial Times, March 20, 2018, available at $<$ https://www.ft.com/content/2d2086ee-2ba0-11e8-9b4b-bc4b9f08f381? desktop=true\&segmentId=7c8f09b9-9b61-4fbb-9430-92 08a9e233c8\#myft:notification:daily-email:content>. 29 "Venezuela's Oil-Backed Crypto Petro Grows Thanks to a Little-Known Russian Bank," CCN.com, May 14, 2018, available at <https://www.ccn.com/ venezuelas-oil-backed-petro-is-expanding-thanks-to-alittle-known-russian-bank/>.

${ }^{30}$ Juan Pablo Cardenal, "Navigating Political Change in Argentina," In Sharp Power: Rising Authoritarian Influence. National Endowment for Democracy (December 5, 2017), 60, available at <https://www.ned. org/sharp-power-rising-authoritarian-influence-forum-report/>.

${ }^{31}$ ALBA is the Spanish acronym for the Bolivarian Alliance to the Americas, an economic and political alliance begun by the late former Venezuelan president Hugo Chavez and led by Venezuela. See Joel D. Hirst, "A Guide to ALBA," Americas Quarterly, available at <https://www. americasquarterly.org/hirst/article>.

${ }^{32}$ See for example R. Evan Ellis, China on the Ground in Latin America (United States: Palgrave MacMillan, 2014).

${ }^{33}$ Ricardo Barrios and Benjamin Creutzfeldt, "Thinking Strategically about China and the U.S. in Latin America: A Riposte to Evan Ellis," Global Americans, February 12, 2018.

${ }^{34}$ Like the Russian visits, Chinese senior offiicials' visits to Latin America were conducted through an opensource review of publications related to visits.

${ }^{35}$ Antonio C. Hsing, "As America Withdraws from Latin America, China Steps In," The Diplomat, January 4, 2018, available at <https://thediplomat.com/2018/01/ as-america-withdraws-from-latin-america-china-steps-in/> .

${ }^{36}$ Author interviews with Latin American and U.S. military officials involved in the U.S. exchange programs.

${ }^{37}$ R. Evan Ellis, "Panama's recognition of the PRC: Strategic implications and recommendations for the U.S.," Global Americas, June 13, 2017, available at < https:// theglobalamericans.org/2017/06/panamas-recognition-prc-strategic-implications-recommendations-u-s/>.

${ }^{38}$ Ministry of Foreign Affairs of the People's Republic of China, available at <http://www.fmprc.gov. cn/mfa_eng/zxxx_662805/t1556546.shtml $>$.

${ }^{39}$ R. Evan Ellis, "Latin America and the

Emerging Ideological Struggle of the 21st Century," Global Americans, June 17, 2018, available at $<$ https://theglobalamericans.org/2018/06/ latin-america-and-the-emerging-ideological-struggle-of-the-21st-century/>. In recent months, China has looked to actively expand this activity into Latin America. See Fabian Cambero and Dave Sherwood, "China Invites Latin America to Take Part in One Belt, One Road," Reuters, January 22, 2018, available at $<$ https://www.reuters.com/article/us-chile-china/ 
china-invites-latin-america-to-take-part-in-one-belt-oneroad-idUSKBN1FB2CN $>$.

${ }^{40}$ Jorge Heine and Anders Beal, "The Strategy Behind China's Diplomatic Offensive in Latin America," Americas Quarterly, May 14, 2018.

${ }^{41}$ David Dollar, "Chinese Investment in Latin America Continues to Expand," The Brookings Institution, March 20, 2018, available at <https://www.brookings.edu/ research/despite-slowdown-chinese-investment-in-latin-america-continues-to-expand/>.

${ }^{42}$ Peter J. Meyer, "U.S. Foreign Assistance to Latin America and the Caribbean: FY2018 Appropriations." Congressional Research Service, May 9, 2018, available at <at https://fas.org/sgp/crs/row/R45089.pdf>.

${ }^{43}$ For a comprehensive overview of the U.S. Department of States's foreign assistance budget, see their website at: <https://www.state.gov/f/budget/index.htm $>$. Conversely, the Department of Defense is not required to publicize the funding that it provides to Latin America and other regions in the form of security cooperation and assistance, and so there are no numbers available to estimate the levels of military aid provided by the United States to Latin America; .

${ }^{44}$ R. Evan Ellis, "Latin America and the Emerging Ideological Struggle of the 21st Century," June, 17, 2018, availabale at <https://theglobalamericans.org/2018/06/ latin-america-and-the-emerging-ideological-struggle-ofthe-21st-century/>.

${ }^{45}$ Bloomberg Editorial Board, "China could have a say on Venezuela's Future,” Bloomberg News, July 18, 2017, available at $<$ https://www.bloomberg.com/view/ articles/2017-07-18/china-could-have-a-say-on-venezuela-s-future>; Fabiola Zerpa, "Venezuela Says China Investing \$250 Million to Boost Oil Output," Bloomberg, July 3, 2018, available at <https://www.bloomberg.com/ news/articles/2018-07-03/venezuela-says-china-investing-250-million-to-boost-oil-output>.

${ }^{46}$ Ricardo Barrios, "China's State Media in Latin America: Profile and Prospects," Asia Dialogue, May 28, 2018, available at $<$ http://theasiadialogue. com/2018/05/28/chinese-state-media-in-latin-americaprofile-and-prospects/>.

47 "Xinhua News Agency ready to Deepen Media Cooperation in LatAm: Xinhua president," Xinhua, November 26, 2016, available at <http://www.xinhuanet. com/english/2016-11/26/c_135859661.htm >.

${ }^{48}$ Devin Thorne and Ben Spevack, "Harbored Ambitions: How China's Port Investments Are Strategically Reshaping the Indo-Pacific," C4ADS, 2017, available at $<$ https://staticl.squarespace.com/ static/566ef8b4d8af107232d5358a/t/5ad5e20ef950b777a94b55c3/1523966489456/
Harbored+Ambitions.pdf $>$.

${ }^{49}$ Joseph M. Humire, After Nisman: How the Death of a Prosecutor Revealed Iran's Growing Influence in the Americas," Center for a Secure Free Society, June 21, 2016, available at <http://www.securefreesociety.org/ publications/after-nisman-how-the-death-of-a-prosecutor-revealed-irans-growing-influence-in-latin-america/>.

${ }^{50}$ Douglas Farah, "The Murder of Alberto Nisman: How the Government of Cristina Fernández de Kirchner Created the Environment for the Perfect Crime," International Assessment and Strategy Center, March 2015.

${ }^{51}$ For a more comprehensive look at this plot see: Hearing on Threat to the Homeland: Iran's Extending Influence in the Western Hemisphere before the U.S. House of Representative's Committee on Homeland Security Subcommittee on Oversight and Management Efficiency, 113th Congress (2013), Statement of Dr. Matthew Levitt, Director, Stein Program on Counterterrorism and Intelligence, The Washington Institute for Near East Policy.

${ }^{52}$ Benjamin Weiser, "Man Sentenced in Plot to Kill Saudi Ambassador," New York Times, May 30, 2013, available at <http://www.nytimes.com/2013/05/31/nyregion/ mansour-arbabsiar-sentenced-for-plot-to-kill-saudiambassador.html >.

${ }^{53}$ For a more complete look at the Venezuela-Iran relationship and the doctrine of asymmetrical warfare see: Douglas Farah, "Transnational Organized Crime, Terrorism and Criminalized States in Latin America: An Emerging Tier-One National Security Threat," Strategic Studies Institute, U.S. Army War College, August 2012. This information comes from sources with direct knowledge of events in both Argentina and Venezuela.

${ }^{54}$ Douglas Farah and Pamela Philips Lum, "Ecuador's Role in Iran's Latin American Financial Structure: A Case Study of the Use of COFIEC Bank," International Assessment and Strategy Center, May 2013.

${ }^{55}$ Admiral Kurt W. Tidd, "Prepared Remarks" Center for Naval Analysis", June 2018, available at <http://www.southcom.mil/Media/Speeches-Transcripts/ Article/1543839/prepared-remarks-adm-tidd-at-centerfor-naval-analyses/>.

\section{Photos}

Page 96. Licensed under Creative Commons Attribution 2.0 Generic License. Photo unaltered. 


\section{CENTER \\ ONIRREGULAR WARFARE ANDARMED GROUPS}

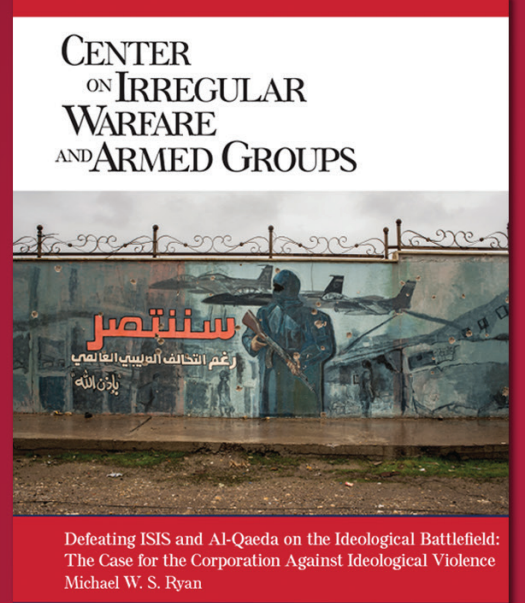

United States Naval War College Newport, Rhode Island

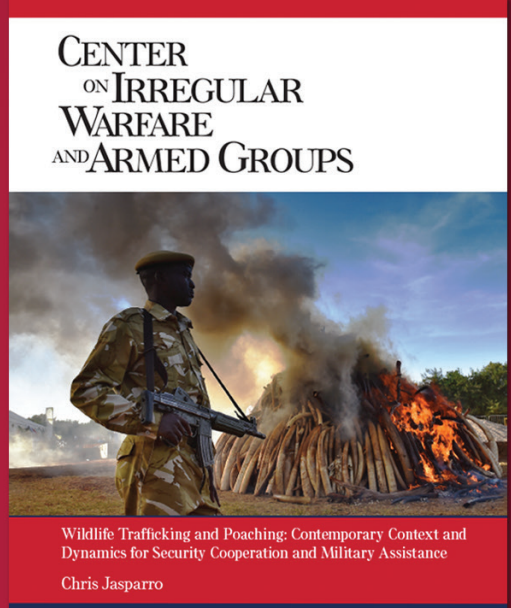

United States Naval War College Newport, Rhode Island
(9)

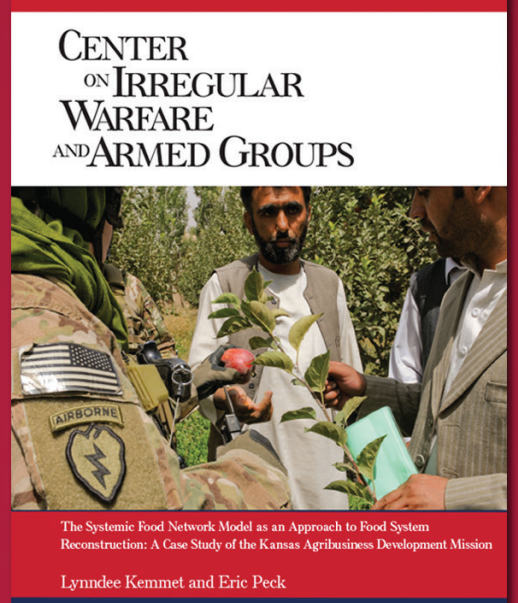

United States Naval War College Newport, Rhode Island

The Center on Irregular Warfare and Armed Groups is dedicated to the interdisciplinary study of the challenges presented by irregular warfare and non-state actors. CIWAG's aim is to produce cutting edge research case studies that assist professionals preparing to meet the complex challenges of the post-9/11 world, while aiding the work of operators, practitioners, and scholars of irregular warfare.

Visit us online at www.usnwc.edu/ciwag

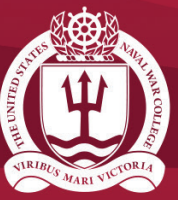




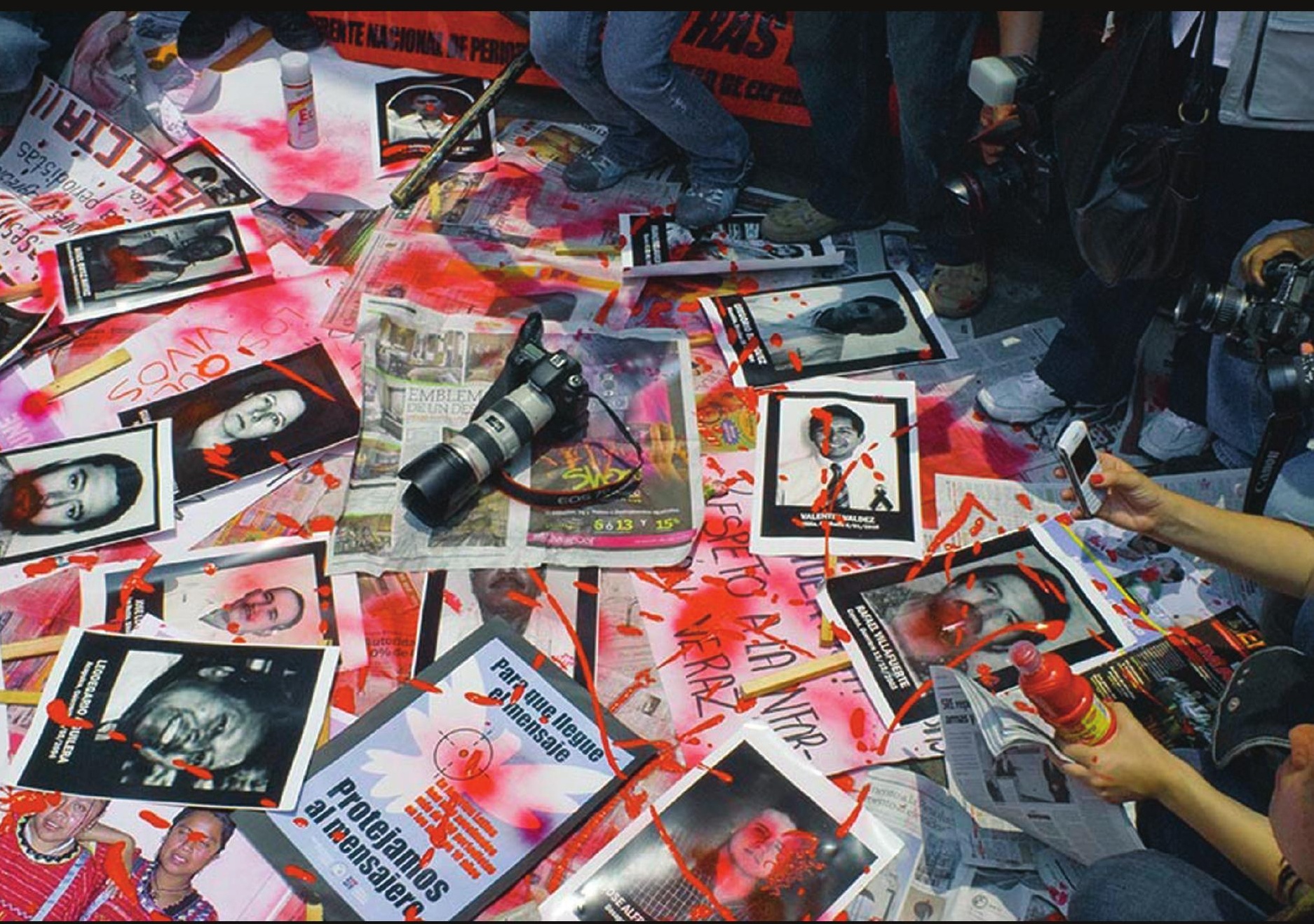

In August 2010, hundreds of Mexican journalists silently marched in downtown Mexico City in protest of the kidnappings, murder and violence against their peers throughout the country. (Knight Foundation) 


\section{Only Connect: the Survival and Spread of Organized Crime in Latin America}

By Ivan Briscoe and David Keseberg

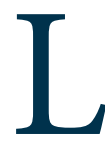
egend has it that Pope John Paul II, during his visit to Guatemala at the height of that country's civil war in 1983, handed down a highly undiplomatic refrain to his official hosts: "you like to kill." It is a conclusion that, decades on from the Cold War era of military dictatorships, left-wing revolutionary regimes, and embattled democracies, is still largely valid across Latin America, although for quite different reasons. This is the region of the world that is now least affected by armed conflict, yet most exposed to a daily dose of largely criminal violence. In 2016, 17 of the 20 countries and 43 of the 50 cities with the world's highest rates of homicide- excluding those affected by armed conflict—were to be found in Latin America. ${ }^{1}$ In absolute terms, one in four global homicides occurs in only four countries: Brazil, Mexico, Venezuela, and Colombia. ${ }^{2}$ This lethal yet commonplace violence is most closely associated with those countries saddled with the presence of vibrant criminal organizations, groups which are in turn associated in the minds of many Latin Americans with the spread of sinister tentacles across poor urban communities, peripheral rural areas, prisons, police forces, judges, eminences of the political establishment, and international bankers and lawyers. Crime no longer appears as a mere underworld, but has become a source of fear, resentment, popular entertainment and, perhaps most crucially, livelihood and opportunity; it has become a culture.

However, this broad-brush depiction of Latin America as a fertile territory for bloodthirsty cartels does not do justice to the complex path that organized crime has taken in the past four to five decades. From the time when the first major independent drug trafficking organizations emerged and the Cold War regimes of the region, often with their own flourishing illicit enterprises, began to subside, the region's criminal groups have morphed towards ever higher levels of complexity, differentiation, and selectivity in their areas of influence. Their presence and the violence they mete out is highly uneven: rates of murder not only vary greatly between countries, but also within them. ${ }^{3}$ The safest region of Mexico, Yucatán, suffered a mere 2 percent of the murders recorded in 2017 in the country's most murderous state, Guerrero, and notched up roughly the same homicide rate as Belgium. ${ }^{4}$ Similarly extreme disparities in murder rates are found in Brazil and Guatemala.

An extraordinarily diverse array of criminal groups and armed factions is now engaged in illicit activity across the region, each with its own mores and footprints. These range from street gangs or maras in the

Dr. Ivan Briscoe is the Program Director for Latin America and the Caribbean of the International Crisis Group, based in Bogota, Colombia. Mr. David Keseberg is a research assistant in the Americas Research Division, Stiftung Wissenschaft und Politik, in Berlin, Germany. 
Northern Triangle of Central America to criminal fiefdoms in Brazil, from drug cartels and criminal syndicates in Mexico to guerrilla forces and dissidents in Colombia, Mexico, and Paraguay, and from militias formed by former members of the security forces in Brazil to neo-paramilitary groups in Colombia. Whereas peripheral and border territories across Latin America-themselves shaped by a historically limited state presence-have provided plenty of opportunities for criminal groups to thrive, these organizations have grown and diversified in complicity; direct or indirect; overt or tacit; active or passive alongside their local communities, security forces, and state authorities at multiple different levels. ${ }^{5}$ Strategic trading hubs such as the port cities of Tumaco and Buenaventura on Colombia's Pacific Coast or border cities such as Ciudad Juárez in Mexico or Ciudad del Este, located in the tri-border area of Paraguay, Argentina, and Brazil, have lost none of their appeal to organized crime and commercial hustlers. Peripheral areas of major cities, for their part, now act as magnets for gangs and extortion rackets. Meanwhile, the deep rural hinterlands of Colombia and Venezuela have become hubs for multiple forms of illicit trafficking, coveted by competing armed factions often acting in league with military and state officials. ${ }^{6}$

Aside from the insecurity and violence they generate, armed criminal groups exert demonstrable political, social, and even electoral influence over certain circumscribed territories, both rural and urban. ${ }^{\text {? }}$ At the same time, their sway over national democratic politics through the use of channels of high-level corruption and influence trafficking remains opaque, although numerous scandals corroborating these connections have fueled public outrage. ${ }^{8}$ Electorates across Latin America have already taken great offense at evidence of these high-level illicit linkages, most notably in Guatemala and Mexico, and tend to regard the infiltration of criminal actors in political life as a large part of the reason for the failure of governments to handle resources properly or provide adequately for their populations. ${ }^{9}$

The combination of chronic criminal violence, selective territorial control, and supposed national political influence together represent an interconnected series of threats, to both public well-being and the stability of democracies. More immediately, they have prompted across Latin America an assortment of public responses that have included traditional demands for tougher law enforcement (so-called mano dura) but have more recently featured calls to prosecute corrupt officials, purge state bodies and security forces, or recast entirely the ruling paradigms of security policy. Meanwhile, vigilante violence and eroding faith in democracy show some of the risks of failing to address public anxieties over lawless streets and venal practices in high office.

\section{The Reconfiguration of Organized Crime}

More than a decade after then-President Felipe Calderón declared Mexico's war on drugs, the country's public security crisis has descended into a trough. The year 2017 went down as the country's bloodiest since official records began some 20 years ago, with 29,168 registered homicides. An even greater number of violent deaths are expected in $2018 .{ }^{10}$ Instead of disrupting command structures, debilitating criminal organizations and reducing criminal violence, the cure promulgated by Calderón and perpetuated by his successor Enrique Peña Nieto has proven worse than the disease. The war on drugs, the deployment of troops and militarized policing strategies to wage it, and the targeting of high-ranking members of organized crime groups in effect accelerated an incipient process of fragmentation in the criminal underworld towards horizontal networks of smaller outfits.

\section{Adapting to Crackdowns}

Major drug cartels that once had the means to control the entire drug trade between Colombia and 
the United States have splintered into an inter-connected array of national and regional cartels, local mafias, and national and transnational trafficking networks (transportistas). At the end of Peña Nieto's sexenio (six-year term), estimates suggest up to 300 criminal groups could have been operating across Mexico. In comparison, during Calderón's tenure only eight major cartels fought for access to and control over drug trafficking routes to the north. ${ }^{11}$

In the course of this fragmentation, criminal groups that lost access to or were left in control of minor segments of the trafficking routes diversified their illicit activities, which in turn fueled turf wars in which local communities bore the brunt of intensifying cartel violence. ${ }^{12}$ Opting primarily for predatory or extractive criminal rackets, including (but not limited to) extortion, kidnapping, human smuggling, and resource theft, particularly illegal siphoning of oil (huachicoleo), many of these new criminal groups have tended to prey on local communities in order to make up for their losses in traditional drug-related revenue streams. ${ }^{13}$ At the same time, narco-trafficking still remains a major source of income and a cause of fighting between a few powerful cartels, such as the Jalisco New Generation Cartel.

Extortion rackets, paired with extraordinarily violent behavior and increased rootedness in local communities and institutions, have become the means par excellence for numerous criminal groups to demonstrate and reinforce social and territorial control. As a result, local communities and authorities are both co-opted and intimidated. In the Northern Triangle of Central America-El Salvador, Guatemala, and Honduras-small-scale extortion has transformed from what was a "relatively smalltime, hyper-local revenue stream" into the most "emblematic crime" of the region, and has become inextricably linked to the phenomenon of gang violence and to the rise of other illicit activities. ${ }^{14}$ In Honduras "some 79 percent of registered small businesses ... and 80 percent of the country's informal traders report they are extorted."15 In neighboring El Salvador, maras extort up to 70 percent of businesses, in particular transportation companies, in municipalities where they are present (estimated to be 247 out of 262 municipalities). ${ }^{16}$ With 692 transportation workers killed in El Salvador between 2011 and 2016 compared to 93 police officers, until quite recently "it has been more dangerous to drive a bus than to fight gang crime."17

During the past 15 years, governments in the Northern Triangle repeatedly opted for mano dura (iron fist) policies-Cero Tolerancia in Honduras, Plan Mano Dura in El Salvador, and Plan Escoba in Guatemala-in a bid to crack down on gang violence. But indiscriminate mass arrests of thousands of alleged gang members did little to weaken criminal structures. On the contrary, the decision to segregate imprisoned gang members according to the group to which they belonged, triggered a structural reorganization, as a result of which the maras evolved into "sophisticated criminal organizations." "Segregation allowed the gangs to turn the prisons into their own criminal fiefdoms and bases of both internal and external operations, facilitating the development of a gang hierarchy where power flowed down from incarcerated gang leaders." ${ }^{\prime 19}$ This transformation process simultaneously mirrored a shift in the scope and nature of illicit activities as maras on the outside set up sophisticated extortion schemes to tax local businesses. Originally a response to the financial needs of their incarcerated gang leaders, these rackets enabled maras to consolidate and extend their territorial and social control in the long term. ${ }^{20}$

The transformation into more vertical and sophisticated criminal organizations was one of the most notable effects of Central America's crackdown on street gangs. But iron fist policies also provoked another subtle yet equally pernicious effect that served to further reinforce street gangs' grip on local communities. Indiscriminate detention of individuals on grounds of suspect behavior and appearance 
rather than proven criminal activity has tended to further alienate both individuals and communities from local and state authorities. The result of this disaffection with the state is all the more significant in the Northern Triangle given that street gangs are, first and foremost, a social phenomenon, rooted in the socioeconomic exclusion of large parts of the population and sustained by pride in their estrangement from mainstream society. ${ }^{21}$ As one expert on street gangs pointed out, in the case of $\mathrm{El}$ Salvador "gangs did not steal the territory from the state, they simply occupied it when it was empty [after the armed conflict]."22 Nowadays, maras in El Salvador draw on a broad estimated social support base of 500,000 people, equivalent to 8 percent of the country's population. Perceived mistreatment by El Salvador's police, in this context, is more likely to drive gang growth than weaken the gangs: one young man observed to Crisis Group that "If they call me a gang member, treat me like a gang member, maybe I am one of them."23

\section{The Social Roles of Crime}

Security policies that address the threat of criminal groups purely through law enforcement fail to take sufficient account of the psychosocial roots of these organizations, and the multiple social and economic roles they have come to play. Adolescents in El Salvador turn towards street gangs for multiple reasons, whether to gain protection from repressive policing or attain a source of identity, pride, and belonging in a context marked by scarce economic opportunities and negligible upward mobility. Meanwhile, firms in Guatemala
City's municipal market have turned to street gangs for protection from more predatory groups, paying extortions on a regular basis. ${ }^{24}$ Naturally, criminal groups are often eager to provide these services to local communities, ranging from the provision of security, mechanisms of conflict resolution and basic economic opportunities, to a sense of collective identity.

Colombia provides perhaps the most prominent regional example, first of the initial success of robust and highly militarized security policies, followed by the subsequent entrenchment of criminal and armed groups' territorial and social control. In 2000, the U.S.-backed initiative Plan Colombia started assisting and financing the Colombian government's strategy to combat drug cartels and left-wing insurgencies. This campaign undeniably weakened the FARC (Revolutionary Armed Forces of Colombia), the country's main insurgent group, and eventually nudged the guerrilla towards negotiations with the Colombian government and the landmark 2016 peace accord. Throughout this period, the country's appalling levels of homicide fell consistently, although credit for this must be shared by activist local governments in Colombia's major cities and by judicial and police reforms and modernizations.

Forced eradication of coca crops formed a backbone of Plan Colombia, based on the understanding that the illicit drug trade drives criminal violence and internal armed conflict. However, massive aerial and manual eradication provoked disenchantment among local communities in peripheral territories, where the revenues generated by coca crops helped 
sustain people's precarious livelihoods. Under the pressure of counter-narcotic offensives, illicit crop production shifted towards the most peripheral and economically deprived parts of the country-notably to border or coastal regions such as Nariño, Cauca, and Putumayo in the south, or to Norte de Santander on the frontier with Venezuela-where it became the life-blood of communities that were already steeped in illicit activity or had few other livelihood options. Criminal groups involved in the drug trade-small-scale drug cartels, left-wing guerrillas, paramilitary groups and their criminal successors, sometimes linked to the armed forces, police, or the state-were able to establish close links with local communities in need of protection services and a market to sell their illegal crops.

This evolution strengthened the legitimacy of criminal groups vis-à-vis perceived corruptible, weak, or absent state authorities that often lacked the means or commitment to enforce the rule of law, resolve local disputes, or boost development in the country's sparsely populated periphery. For example, in 2014 less than 50 percent of Colombia's municipalities-453 out of 1,122-counted on the presence of a public prosecutor's office. ${ }^{25}$ Under recently elected conservative president Iván Duque, whose party led opposition to the peace accord, a failure to deliver on core elements of the agreement such as rural reform and voluntary illicit crop substitution programs risks generating a further backlash in these local communities. ${ }^{26}$ In a context marked by a proliferation and expansion of nonstate armed groups vying to occupy the space left behind by the FARC, this approach could drive disenchanted communities into the arms of these groups, all of them eager to embrace marginalized communities' "orphanhood vis-à-vis the state," as Alma Guillermoprieto has aptly put it. ${ }^{27}$

While organized crime's "transformation into a supplier of resources and goods in marginalized social sectors" has earned it a degree of often grudging social acceptance in Colombia, parts of Central America, and urban Brazil excessively coercive security policies have reinforced the mutual interdependence between criminal groups and local communities. ${ }^{28}$ This is not to say that local communities are intrinsically criminal, nor is it to argue that criminal groups are genuinely interested in the greater welfare of communities in which they operate. For instance, "one community leader in ELN territory in Cauca called the group a 'necessary evil,' because without them thieves and rapists would 'invade' her town." ${ }^{29}$ However, a pronounced shift towards criminal rackets operating within clearly defined territorial limits, and the failure or inability of state authorities to provide basic services, have provided criminal groups with opportunities to shore up a social support base, and fertile ground to undermine, contest, and to a certain degree, erode state authority and legitimacy. As a leader of Brazil's Comando Vermelho fittingly put it, "The gangs, no matter which, are part of the favelas. We come from it and blend into it, are part of the fabric."30

\section{Territorial Control and State Linkages}

The shift toward firm control over relatively small parcels of territory can be regarded as one of the defining features of contemporary organized crime in Latin America. While the move toward territorial control derives in large part from the evolution in criminal markets, and the rising significance of extortion and other predatory rackets, repeated and prolonged exposure to coercive, often militarized security policies have obliged criminal groups to develop more complex coping strategies to mitigate the potential threat to their operations. For instance, patterns of criminal violence in Latin America show how extraordinarily selective these groups have become in terms of who is being targeted, where, and for what purpose. High profile and outspoken members of society such as local politicians, journalists, 
community leaders, and human rights activists are on the front line of communities exposed to the ambitions of criminal groups. In 2017, at least 212 human rights defenders were killed in Latin America and the Caribbean, equivalent to an estimated 68 percent of all registered homicides of human rights defenders globally; 156 murders or 50 percent of the global death toll, took place in Brazil and Colombia. ${ }^{31}$ In the runup to Mexico's general elections in July, an estimated 80 percent of acts of political violence, including homicides, assaults, and threats, pointed to the involvement of organized crime. ${ }^{32}$

The trend toward highly selective use of violence is underscored by its uneven geographic spread, even within confined areas exposed to high levels of homicide. At present, 80 percent of homicides in Latin America's large- and medium-sized cities occur on just 2 percent of streets. ${ }^{33}$ Not all of this concentrated violence can be ascribed to menacing shantytowns or deprived urban areas. Somewhat surprisingly, Mexico remains one of the world's top ten tourism destinations despite homicides skyrocketing in some of its major beach resorts. ${ }^{34}$ Indeed, the resort of Los Cabos in Baja California ranked first and Acapulco, in the state of Guerrero, third among the world's most homicidal cities with more than 300,000 inhabitants not affected by armed conflict, with homicide rates of 111.33 and 106.63 respectively. ${ }^{35}$ Los Cabos nevertheless continues to sustain a thriving trade in foreign tourism, even as the internecine criminal violence occasionally intrudes onto beaches and into hotel lobbies. ${ }^{36}$ In spite of the tremendous violence criminal groups are disposed to deploy, they also seek to divert or minimize the attention of state authorities and security forces by keeping a low profile or by controlling local media (in Mexican argot, they seek to enfriar la plaza). ${ }^{37}$ Especially in the Baja California peninsula, where vested economic interests are at stake-control over drug trafficking routes further north and the potential drug trade servicing tourists in beach resorts-criminal rivalry for spoils is fierce, but the desire to become involved in a prolonged war with security forces is scant.

Large-scale atrocities such as the Piedras Negras and Allende massacres in Coahuila state committed by the Zetas cartel in response to former Zetas operatives' collaboration with U.S. authorities in March and April 2011, and the disappearance of 43 students in Iguala, Guerrero, in September 2014, have seemingly become less frequent. Although extremely effective in terms of cowing local communities, major atrocities run counter to efforts to establish rigorous local control by stirring public indignation at the national and international level, or stoking calls for a military crackdown on territories infested by crime. ${ }^{38}$ Rather than perpetrating mass killings or displaying excessive levels of violence, enforced disappearances have instead become one of the preferred methods of exerting criminal control in Mexico. From 2007 to April 2018, more than 36,000 cases of disappeared people have been registered at the national level..$^{39}$ In the Mexican state of Veracruz, where murder rates prior to 2016 were relatively low compared to other regions, 2,750 cases of disappearances have been reported to state prosecutors; civil society organizations fear the numbers could reach as high as $20,000 .^{40}$ 
Illustrating the sheer magnitude of enforced disappearance, these numbers hint to a yet more sinister feature of contemporary organized crime: the porosity of barriers between state, security forces, and crime as the latter blends into its host societies. The perpetration of such large-scale human rights violations would certainly not have been possible without multiple links between state and non-state agents, which have created a permissive environment for state-criminal collusion. This phenomenon has been particularly pervasive in the case of Mexico as a consequence of its prolonged war on drugs, with criminal groups marshaling resources to neutralize potential security responses before they materialize. And yet, the Mexican case is in no way unique. Widespread links between criminal non-state and state actors have been evident throughout the region, especially in Guatemala, Honduras, Colombia, Brazil, and Venezuela.

John Sullivan has coined the term "neo-feudal zone" to characterize territories not only contested by criminal groups but also marked by a high depth of criminal penetration, including the maintenance of mercenary armies, taxation of economic activities via entrenched extortion schemes, and the extraction of resources, as well as domination over local political and community authorities to avert potential security responses. ${ }^{41}$ Far from being a one-sided relationship, however, "neo-feudal zones" need not subsist solely in the dominion of organized crime. State officials have continuously co-opted criminal groups to pursue their own economic and political interests. And in this respect, the crackdowns and law enforcement strategies preferred in most Latin American countries as the means to fight crime have spurred major shifts in the nature of illicit networks among criminal groups, the private sector, and state agents. State agents have in some cases managed to appropriate the contemporary dynamics of organized crime for their own purposes, and thereby redefine the scope and nature of state-criminal collusion.

\section{Latin America's Modern Democracies}

More than three decades into the Third Wave of Democratization, Latin America at large has consolidated the foundations of liberal democracy. Strengthened state, judicial, and electoral institutions across the region, though far from perfect, have mostly allowed for the peaceful alternation in power between opposing political parties, with both right and left wing forces competing for mass public support. This is a far cry from prolonged periods of military dictatorship and authoritarian rule, whether in the Cold War or interspersed throughout the region's post-colonial history.

\section{Subnational Authoritarians}

In the 1990s, new parties began to eclipse their disgraced but long dominant forerunners. The fragmentation and decay of traditional parties and the high tide of alternative political forces from across the ideological spectrum have exacerbated the dependence of national forces on local party structures for electoral backing. The nature of relations between local-level and national politics, especially in times of elections, has enticed scholars to argue that formal advancement towards and consolidation of democracy "has been territorially uneven and mostly limited to the national level." ${ }^{\text {"2 }}$ Referred to as "regime juxtaposition," scholars argue that the transition towards democracy at the national level does not necessarily go hand-in-hand with the abandonment or withering of subnational undemocratic regimes, or "subnational authoritarianism." ${ }^{\text {"3 }}$ Under these local authoritarian enclaves, systemic corruption, practices of electoral fraud, restriction of civil rights, and targeted violence as means to pursue vested political interests belie the creation of formal democracies, and prepare the way for the consolidation of "neo-feudal zones." 44

The transition of Mexico toward a multiparty democracy in 2000 after 71 years of hegemonic rule by the Institutional Revolutionary Party (PRI) is 
the example par excellence of this political opening. Mexico's transition has profoundly reshaped the relations between federal and state governments, transferring considerable powers to the latter and earning them the epithet "viceroyalties," in reference to the omnipotent jurisdictions of colonial Spanish America. ${ }^{45}$ In fact, Mexico's state governors have come to embody the very core of what constitute subnational undemocratic regimes: 14 former and current state governors are being investigated for corruption and links to organized crime. ${ }^{46}$

The Mexican state of Veracruz is a case in point, illustrating the extent to which criminal groups, especially the Zetas cartel and its successors, have been able to infiltrate and corrupt state authorities, and vice versa. According to a Crisis Group report, under former governors Fidel Herrera Beltrán and Javier Duarte, "Veracruz played host to increasingly fluid political and criminal interconnections, accelerating its descent into extreme insecurity." ${ }^{\prime 47}$ An illicit network bridging organized crime and state agents, including high officials in the police force, the state attorney's office, and the state government, enabled the installation of a regime of fear designed to loot public resources, prey on civilians and, if necessary, eliminate dissenting voices within state authorities and beyond. With 23 assassinations and 8 enforced disappearances since 2011, Veracruz has become Mexico's most dangerous state for journalists to work in. ${ }^{48}$ The strategy of the Zetas cartel and its fragmented successor groups to actively blend into and assimilate local and state power structures protected them in large part from repressive state interventions and judicial prosecution. Collusion between organized crime and state authorities at the highest level, created a permissive environment in which criminal organizations could engage in illicit activities while shielded behind a cloak of impunity.

Furthermore, police chiefs, emboldened by complicity with organized crime groups, used their authority over lower level police officers to establish a "regime of terror" within the force designed to serve criminal purposes.

One way was to adopt a passive response to crime. Officers were explicitly instructed to reject citizens' requests of help and assistance, to arrive late at crime scenes, to not report sightings of suspicious vehicles and armed individuals or groups, and to stay clear of ongoing armed confrontations, according to a former police officer... Active participation in criminal operations, including kidnappings-for-ransom and forced disappearances, formed another part of police operations. ${ }^{49}$

This level of criminal influence over the security force is increasingly echoed elsewhere in Mexico, such as in the states of Michoacán and Guerrero. In Coahuila, the Zetas cartel infiltrated the security forces to the degree that they could use state prisons as a safe haven to escape persecution.

Colombia's "parapolitics scandal" is another case in point, and remains one of Latin America's emblematic cases regarding the scope and nature of state-criminal collusion. Subnational undemocratic regimes flourished across Colombia in the wake of the opening of its political system and decentralization of state power, a process that began with the introduction of local elections for mayors in 1986 and was enshrined in the constitutional reform process of 1991. As a perverse result of reforms intended to deepen the country's democracy, local political elites frequently engaged in alliances with paramilitary groups, and vice versa, to preserve the status quo. Following the demobilization of the United Self-Defense Forces of Colombia (AUC), the national paramilitary umbrella organization, in late 2006, revelations emerged regarding what would come to be known as the "parapolitics scandal:" an extensive web of links between paramilitaries and politicians, ranging from mayors and local politicians 
to governors and members of Colombia's National Congress. By April 2016, 102 members of Congress and 97 Senators were under investigation, 42 of whom had been convicted..$^{50}$ "[R]eflecting the degree of political ambition of different paramilitary fronts, economic interests and local conflict dynamics," the depth of criminal penetration of local political life as well as the preferred means of exerting power over communities-whether through intimidation, violence, social and territorial control, or briberydiffered across the country. ${ }^{51}$ This recent history of criminal co-option of political life continues to resonate deeply within contemporary Colombia. ${ }^{52}$

Driven by their hunger for votes in highly competitive electoral arenas, the dependence of relatively new, fragile, and weakly structured national parties on local party bosses to secure votes has reinforced subnational authoritarian regimes. Of course, national politics is hardly free of illicit influences, particularly as power fragments across various parties and interest groups. The complex transactions between executive and legislative powers, opaque public procurement practices, and opportunities to secure future favors through illicit financing of election campaigns have provided the main avenues for corruption across national politico-economic elites in the region. Latin America's largest and most resonant corruption scandals in recent years, those of Petrobras and Odebrecht in Brazil, exemplify how these domestic political arrangements and powerful business and government cabals fostered corruption rackets, which were later redeployed across Latin America's political elites. ${ }^{53}$

Local political contexts shaped by cronyism and rent-seeking have been at the forefront of the interests of organized crime due to the opportunities to co-opt underpaid local police forces, gain public contracts to launder money and divert public funds for illicit enrichment, while also benefiting from comparatively lower levels of institutional oversight and media coverage. Tellingly, the entire police force of the municipality of Ocampo, in the Mexican state of Michoacán, was arrested on charges of alleged links to the organized crime and its involvement in the assassination of a candidate running for mayor in June 2018. ${ }^{54}$ Political opportunism and vested interests have created natural incentives for incumbents and criminal groups alike to engage in mutually beneficial relationships, and for state authorities and national parties to turn a blind eye to their illicit and often violent nature.

\section{Political Violence and Influence}

For more than 70 years, the hegemonic rule of Mexico's PRI forged a system of mutual accommodation between criminal groups and state agents at multiple levels, establishing a "state-sponsored protection racket" that granted license and impunity to illicit organizations in exchange for their readiness to observe certain controls over their activities. ${ }^{55}$ Mexico's transition towards a multiparty democracy, while raising the potential benefits to political parties and candidates of colluding with criminal groups, also caused the breakdown of established arrangements that reached to the heart of the central state. The emerging political divisions and rivalries between municipal, state, and federal levels within a multiparty system meant that guarantees of impunity traditionally enjoyed by organized crime under the system of vertical one-party rule could not be vouchsafed. In a bid to recover these benefits, criminal groups resorted to violence, intimidation, and co-option as leverage in negotiations with the new political authorities, above all at the local level. As a result, illicit networks now find themselves in a constant state of flux, with violence spiking during election campaigns as relations between criminal groups and state officials or political candidates are reshuffled. 
While it is not always clear whether a particular case of political violence in Latin America is the work of organized crime or of inter- and intra-party feuds, targeted violence against politicians has become pervasive, especially in Mexico and Brazil. Ranging from coercive actions to prevent undesirable candidateseither those affiliated with rival groups or others pushing for reforms that could have potentially adverse effects on illicit revenuesfrom running for office to killings of political contenders, a dominant pattern has become the targeting of politicians, especially from the opposition, at the municipal level prior to polling day. At least 152 political candidates and activists were assassinated in Mexico during the 2018 election campaign. ${ }^{56}$

An estimated 80 percent of these murders targeted politicians at the municipal level, and 60 percent of the victims formed part of the opposition. ${ }^{57}$ In Brazil, homicidal violence against politicians is lower, with 9 incumbents murdered on average per year since 2007. But of the 98 political assassinations registered over the past decade 28 of them, or 32 percent, were in 2017. During the decade all reported victims held office at the municipal level: 85 town council members, four mayors, and one deputy mayor. ${ }^{58}$

Criminal groups' readiness to resort to violence by no means represents the only way they exert influence over local authorities. The shift towards tighter territorial control by illicit groups, against a background of political fragmentation and weakened party structures, has spurred other avenues for collusion. Criminal groups' control over local communities is of particular interest to political forces as these organizations have the power to stifle opponents' electoral campaigns, or hand over blocks of voters to a preferred candidate. In Brazil's urban peripheries, especially in Rio de Janeiro and São Paulo, the nature of illicit activities effectively shapes "criminalized electoral politics" between criminal and political actors. While criminal groups engaging in non-extractive illicit activities (e.g. drug retail) primarily target political rivals, predatory criminal groups capitalize on their control over local communities to influence voter intentions during elections and translate it into political power. ${ }^{59}$ Although the extent and degree of this phenomenon is hard to quantify, militias formed by former security force members are reckoned to control 45 percent of Rio de Janeiro's favelas-an estimated two million people - and drug gangs a further 37 percent. $^{60}$ Revelations that political leaders of both ARENA and FMLN allegedly made payments of $\$ 350,000$ to El Salvador's major street gangs, MS-13 and Barrio-18, prior to the 2014 presidential elections in exchange for votes highlight their potential influence over the country's electoral processes. ${ }^{61}$ As a veteran government official put it:

Let's be honest: every single party in this country talks to gangs, how they would not, since they have to organize rallies in their territories? ${ }^{62}$

\section{Corruption and Eroding Confidence}

High levels of electoral competitiveness have driven up the costs of electoral campaigning across Latin 
America. Patchy regulations and lax enforcement of election financing across the region have traditionally propelled illicit funding, and private companies have made extensive use of these channels of influence to gain preferential access to public contracts or other favors from the state. ${ }^{63}$ These practices reached an extreme in the case of Brazilian construction company Odebrecht, accused of paying $\$ 788$ million in bribes across 12 countries, most of them in Latin America. Even though the Odebrecht case has not pointed to any intimate links between political and business elites and violent organized crime, it does, at the very least, cast light on a certain proximity and overlap between different types of illicit activities. In fact, in Colombia the Odebrecht payments have been primarily made to politicians that were investigated or allegedly linked to the "parapolitics scandal," as was the case of Senators Álvaro Ashton and Musa Besaile. ${ }^{64}$

While the judiciary is traditionally intended to serve as a check on abuses of power, judicial systems across the region have not been spared involvement in outrageous corruption cases. In 2017, the highest spheres of Colombia's judicial system were rocked by the "Cartel de la Toga" case, which appeared to point to the sale of impunity to rich, high-level politicians. Accordingly, members of Colombia's Supreme Court and now disgraced anti-corruption prosecutor Luis Gustavo Moreno set up a sophisticated extortion scheme to manipulate ongoing prosecutions in exchange for bribes, targeting in particular politicians investigated for corruption charges and linked to the "parapolitics scandal." ${ }^{35}$ Again, although collusive actions between violent criminal organizations and state or judicial actors do not lie at the core of the "Cartel de la Toga" case, as with the Odebrecht scandal, parapoliticians seemingly constitute the nexus between distinct illicit networks which, at the very least, share labyrinthine channels of influence and meeting spaces.

The perceived ease with which politicians, the judiciary, business elites, and criminal groups have

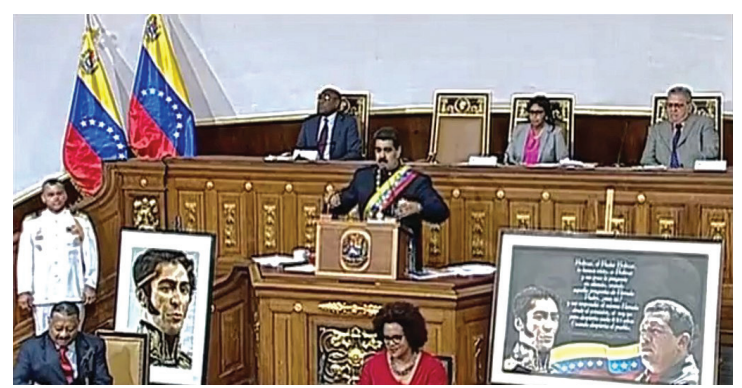

President Maduro speaking at a Venezuelan Constituent Assembly session on August 10, 2017. (Presidency Press)

been able to share these spaces of encounter within democratic systems-engaging in the process in all manner of illicit secondary markets in state and judicial power-has helped to sow deep public disenchantment with democracy. According to the 2017 regional survey by Latinobarómetro, despite the region's authoritarian past a mere 53 percent of the population on average prefer democracy over other political systems, and only 30 percent are satisfied with democracy. On the contrary, a staggering 79 percent believe that the system is designed to benefit elites rather than the public interest-a figure that has risen in recent years. Unsurprisingly, democratically elected institutions such as government and congress, as well as the judiciary and political parties, make up the least trusted institutions within the state, with 25 percent of Latin Americans or less approving of them. Once again, these rates are also falling. ${ }^{66}$

\section{Populist Responses and Risks}

Rampant insecurity and pervasive levels of systemic corruption and impunity have provided fertile ground for populist attacks on the political establishment by modern caudillos from the left and right. Playing on public concerns over insecurity and corruption, charismatic leaders have evoked the prospect of providing quick, comprehensive solutions to these maladies, whether through crackdowns on crime, eradication of corruption or the prospect of generating economic miracles. As a result, the complex issues that are intimately bound up with the region's 
public security crises, whether as cause or consequence-such as illicit coca cultivation in Colombia, socio-economic and ethnic exclusion in Brazil, or illegal migration in Central America's Northern Triangle-are frequently simplified and demonized, thereby concealing and misrepresenting the problems that governments should address as a priority and in a holistic fashion. With crime and corruption reportedly the region's main concerns, it is not surprising that the armed forces traditionally fare the best after churches in public opinion surveys in Mexico, Central America's Northern Triangle, Colombia, Venezuela, and Brazil, even though support for them is wavering as a result of excessive use of violence and human rights violations. ${ }^{67}$ At the same time, exceptions to the clamor for iron fist security approaches are becoming far more prominent, most notably in the anti-corruption drive in Guatemala, and in Colombia's various peace processes under former President Juan Manuel Santos. Most recently, the newly elected president of Mexico Andrés Manuel López Obrador has vowed to dismantle the 12-year "war on drugs," although it is still too early to determine the potential political consequences of his huge electoral success, given its basis in his personal integrity and resolve rather than on concrete policy proposals.

Venezuela now constitutes the outstanding example of how the concentration of executive power and veneration of a messianic leader has only served to exacerbate the original condition that the public had voted to cure. With pledges to dismantle the highly corrupt politico-economic establishment that ruled the oil-rich country and quash the inequity it perpetuated, the populist government, first led from 1999 by Hugo Chávez and since 2013 by Nicolás Maduro, has progressively weakened liberal democratic safeguards and created a factionalized authoritarian regime in which crime and corruption have become the glue keeping the system alive. "The creeping authoritarianism of the latter years of former President Hugo Chávez's rule and the first years under Maduro has metastasized into full-blown partisan exploitation of state and judicial institutions." ${ }^{\text {68 }}$ Venezuela's armed forces have long been co-opted by the chavista government through the positioning of high-ranking military officers in strategic positions in ministries and state companies; to a large extent the military have come to form the cornerstone of Maduro's regime. In February 2016, Maduro issued a presidential decree to establish the Arco Minero, a 100,000 square kilometer area for mining south of the Orinoco River in Bolívar and Amazonas states. To run mining operations, potential private investors are obliged to form a joint venture with state-owned companies, such as the newly founded, military-controlled Anonymous Military Company of Mining. ${ }^{69}$ However, independent reports suggest that, despite frequent clashes between the armed forces and criminal groups including gangs, paramilitary structures, and Colombian guerrillas that all operate in the area, the military are colluding with several of these to loot the natural resources within the Arco Minero. "Former [Bolivar] state governor Liborio Guarulla, who left office in 2017, said that in his state, 'those in control [of illegal mining] are the guerrillas, under an unofficial agreement with the armed forces." 70 Tellingly, following the landslide victory of the ruling United Socialist Party of Venezuela (PSUV) in the October 2017 regional elections, clear evidence of electoral fraud surfaced in Bolívar state-for the first time ever in any elections during the chavista era. ${ }^{71}$

\section{Conclusions}

Deeply entrenched over decades, organized crime has married with systemic corruption and high levels of impunity to generate multiple forms of political and economic capital across the ideological spectrum in Latin America. But recent experience gives some provisional grounds for optimism. The end point of popular disaffection with flawed democracies and illicit links between criminal 
groups, political elites, and the private sector need not inevitably result in an embrace of authoritarianism and/or charismatic caudillos. In Guatemala, the UN-backed International Commission against Impunity in Guatemala (CICIG) has gained huge public support after it filed charges of corruption against high-ranking government officials, elected representatives, and military officers, including former President Otto Pérez Molina and former Vice-President Roxana Baldetti, both currently in jail. ${ }^{72}$ The Support Mission Against Corruption and Impunity in Honduras (MACCIH) has also assumed the tall order of disentangling extensive illicit networks in the face of hostile headwinds from the Honduran Congress. ${ }^{73}$ Meanwhile, the Colombian peace agreement has formally set the stage for the Colombian government and former FARC guerrillas to engage in joint endeavors aimed at reducing coca production and dismantling organized crime. ${ }^{74}$

In Mexico, López Obrador's landslide victory in July underlined the failure of the country's war on drugs, and, as in Guatemala, the scale of public support for a clean-out of state and security institutions as well as a more holistic approach to the country's appalling levels of violence. Such an approach could include, but should not be limited to, the greater professionalization of security forces, increased external oversight of police and military, greater use of evidence-based community policing, improved urban planning to prevent segregation and exclusion, progressive and context-specific drug legislation, efforts to reform the jail system and rehabilitate prisoners, and stricter gun controls. Severing the illicit networks that allow criminal groups to collude with political forces and state officials across the region would also require strengthened judicial and prosecution systems, as well as tighter controls on political financing and public procurement practices. It should be obvious that none of these proposals are remotely easy to achieve. There is no simple solution to the corruption and collusion generated by electoral competition and fraught executive-legislative relations aside from greater respect for and enforcement of the law in each country's commanding heights. Nor is there any quick and non-painful corrective to the region's inequality, the absence of the state from peripheral areas, or cross-border illicit trade.

Where disgruntled citizens have led an open revolt against corrupt security forces and rampant crime, the results have proved discouraging. A handful of towns and cities across Mexico have gone to great lengths to effectively secede from the national state in an effort to restore law and order. In Tancítaro, Michoacán, a public uprising led by militias pushed out both cartels and the local police. Yet despite Tancítaro's nominal self-rule-the local government fled in the wake of the revolt-the militias have come to impose themselves in a way painfully reminiscent of the days when drug cartels roamed the streets in league with corruptible local police and government officials. ${ }^{75}$

In short, neither new security policies nor public uprisings are assured of success. Opponents of every reform endeavor are robust and relentless, and a definitive escape from Latin America's vortex of crime, sub-national authoritarianism, corruption, and impunity remains elusive. Governments from both left and right have reinforced coercive and militarized security policies even though the evidence suggests any short-term operational successes are unlikely to be matched by a long-term reduction in criminal violence. A set of "extraordinary measures" introduced by the El Salvadoran government in April 2016 to break the maras' sophisticated jail-based command structures-ironically, the result of the first set of iron fist policies-aims to cut down on communication between incarcerated gang members and their peers outside. ${ }^{76}$ Following the decision by Brazil's federal government to put the military in charge of Rio de Janeiro's police force 
in February 2018, shootouts between the security forces and criminal groups as well as police-related killings have been on the rise. ${ }^{77}$ This drift to coercive security policies is now set to intensify. In a country shaken by major corruption scandals, and where the public darling, former President Lula da Silva, has been imprisoned on corruption charges, populist right-wing hardliner Jair Bolsonaro exploited anti-establishment sentiments to win the presidential election in late October. ${ }^{78}$

Awareness of the counterproductive effects of existing security policies, and the way they have hit, decapitated, and dismantled criminal organizations without preventing the entrenchment of organized crime and its nexus with state and society, is on the rise. But the complementary policies needed to address these chronic dilemmas have not yet been underwritten by a political mobilization strong enough to implement and sustain them. Neither governments nor civil society have yet grasped how to unpick the roles of crime as a livelihood, source of identity, and route to power. Reducing this pervasiveness will require tremendous persistence across politics, the judiciary, and the security forces, possibly more than fragmented democracies allow for, yet certainly more than authoritarian leaders care for. PRISM

\footnotetext{
Notes

${ }^{1}$ Robert Muggah and Katherine Aguirre Tobón, Citizen Security in Latin America: Facts and Figures, Igarapé Intitute, Rio de Janeiro, April 27, 2018, available at <https:// igarape.org.br/wp-content/uploads/2018/04/CitizenSecurity-in-Latin-America-Facts-and-Figures.pdf $>$.

2 "Shining light on Latin America's homicide epidemic," The Economist, 2018, op. cit.

${ }^{3}$ For analysis of the differing murder rates in Latin America in 2017, from Venezuela at the top to Chile at the bottom, see Tristan Clavel, "InSight Crime's 2017 Homicide Round-Up," InSight Crime, January 19, 2018, available at <https://www.insightcrime.org/news/ analysis/2017-homicide-round-up/>.

${ }^{4}$ Laura Calderón, Octavio Rodríguez Ferreira, and David A. Shirk, "Special Report: Drug Violence in Mexico:
}

Data and Analysis Through 2017” Justice in Mexico.Org (San Diego, CA: University of San Diego, April, 2018), available at $<$ https://justiceinmexico.org/wp-content/ uploads/2018/04/180411_DrugViolenceinMexico-12mb.pdf>.

${ }^{5}$ See for example: Ivan Briscoe, Catalina Perdomo and Catalina Uribe Burcher (eds.), Illicit Networks and Politics in Latin America. The Hague: Netherlands Institute for Multiparty Democracy and Netherlands Institute of International Relations (Clingendael, 2014), available at <https://www.idea.int/sites/default/files/publications/illicit-networks-and-politics-in-latin-america. pdf>; José Miguel Cruz, "State and Criminal Violence in Latin America," Crime, Law and Social Change 66, no. 4: 1-22; Ivan Briscoe and Pamela Kalkman, "Illicit Networks: Rethinking the Systemic Risk in Latin America,” PRISM, Vol. 5, No. 4, 151-71.

${ }^{6}$ International Crisis Group, "Containing the Shock Waves from Venezuela," Latin America Report, No. 65, March 21, 2018, available at <https://www. crisisgroup.org/latin-america-caribbean/andes/ venezuela/65-containing-shock-waves-venezuela>.

${ }^{7}$ Enrique Desmond Arias, Criminal Enterprises and Governance in Latin America and the Caribbean. (Cambridge: Cambridge University Press, 2017); Markus Schultze-Kraft, Fernando Chinchilla and Marcelo Moriconi (eds.), "New perspectives on crime, violence and insecurity in Latin America," Crime, Law and Social Change 69, no. 4 (June 2018): 465-73, available at <https:// doi.org/10.1007/s10611-017-9758-3>.

${ }^{8}$ Pew Research Center. Crime and Corruption Top Problems in Emerging and Developing Countries: Most National Institutions Respected, Especially Military, November 6, 2014, available at <http://www.pewglobal. org/2014/11/06/crime-and-corruption-top-problems-inemerging-and-developing-countries/>.

${ }^{9}$ Ivan Briscoe and Pamela Kalkman, op. cit., 2015.

${ }^{10}$ Secretariado Ejecutivo del Sistema Nacional de Seguridad Pública, Informe de víctimas de homicidio, secuestro y extorsión 2017. Mexico City, March 20, 201, available at <http://secretariadoejecutivo.gob.mx/docs/ pdfs/victimas/Victimas2017_022018.pdf>; Karina Suárez, "México alcanza un nuevo récord de asesinatos.," El País, June 22, 2018, available at < https://elpais.com/internacional/2018/06/22/mexico/1529620697_155674.html>.

${ }^{11}$ R. Evan Ellis, "Mexico's Fight against Transnational Organized Crime." Military Review: The Professional Journal of the U.S. Army, Online Edition, May 24, 2018: 4-5, available at <https:// www.armyupress.army.mil/Journals/MilitaryReview/Online-Exclusive/2018-OLE/May/ Transnational-Organized-Crime/>.

${ }^{12}$ Ibid. 
${ }^{13}$ Juan Carlos Garzón Vergara, "From Drug Cartels to Predatory Micro-Networks: The "New" Face of Organized Crime in Latin America," in Reconceptualizing Security in the Americas in the Twenty-First Century. Lanham, edited by Bruce M. Bagley, Jonathan D. Rosen, and Hannah S. Kassab, (Lanham: Lexington Books, 2015), 117-31.

${ }^{14}$ Steven Dudley and James Bargent, The Prison Dilemma: Latin America's Incubators of Organized Crime, InSight Crime, Jan 19, 2017, available at <https://www.insightcrime.org/images/PDFs/2017/ The_Prison_Dilemma-Latin_Americas_Incubators_of_ Organized_Crime_InSightcrime.pdf $>$.

${ }^{15}$ International Crisis Group, op. cit., April 6, 2017, 11 and 15.

${ }^{16}$ International Crisis Group, "El Salvador's Politics of Perpetual Violence," Latin America Report, No. 64, December 19, 2017, Guatemala City-Brussels, 9.

${ }^{17}$ Óscar Martínez, Efren Lemus, Carlos Martínez and Deborah Sontag, "Killers on a Shoestring: Inside the Gangs of El Salvador," The New York Times, Nov 20, 206, available at <https://www.nytimes.com/2016/11/21/world/ americas/el-salvador-drugs-gang-ms-13.html $>$.

${ }^{18}$ International Crisis Group, op. cit., April 6, 2017, 7.

${ }^{19}$ Steven Dudley and James Bargent, op. cit., 2017, 12.

${ }^{20}$ Ibid.

${ }^{21}$ International Crisis Group, op. cit., April 6, 2017; InSight Crime / Center for Latin American and Latino Studies. 2018. MS13 in the Americas: How the World's Most Notorious Gang Defies Logic, Resists Destruction, available at < https://www.insightcrime.org/wp-content/ uploads/2018/02/MS13-in-the-Americas-InSight-CrimeEnglish-3.pdf $>$.

${ }^{22}$ Crisis Group interview, Otto Argueta, Interpeace program coordinator, Guatemala City, February 6, 2017, quoted in: International Crisis Group, op. cit., December 19, 2017, 22.

${ }^{23}$ Crisis Group interview, Carlos Martínez, Journalist at El Faro, July 11, 2017.

${ }^{24}$ International Crisis Group, op. cit., April 6, 2017, 15.

${ }^{25}$ International Crisis Group, op. cit., October 19, 2017, 25.

${ }^{26}$ International Crisis Group, "Risky Business: The Duque Government's Approach to Peace in Colombia," Latin America Report, No. 67, June 21, 2018, available at <Bogotá-Brussels. https://www.crisisgroup.org/ latin-america-caribbean/andes/colombia/67-risky-business-duque-governments-approach-peace-colombia>.

${ }^{27}$ Alma Guillermoprieto, The Heart That Bleeds: Latin America Now (New York: First Vintage, 1995), xii. ${ }^{28}$ Marcelo Moriconi, "Reframing illegalities: crime, cultural values and ideas of success (in Argentina)." Crime,
Law and Social Change, Vol. 69, No. 4, (2018): 497-518.

${ }^{29}$ International Crisis Group, "The Missing

Peace: Colombia's New Government and Last Guerrilla," Latin America Report, No. 68, July 12, 2018, Bogotá-Brussels, 12=, available at <https:// www.crisisgroup.org/latin-america-caribbean/andes/ colombia/68-missing-peace-colombias-new-government-and-last-guerrillas>.

${ }^{30}$ Brad Brooks, "Unfazed by Brazil's Army, Rio drug gangs willing to wait out occupation," Reuters, April 24, 2018, available at <https://www. reuters.com/article/us-brazil-rio-violence-insight/ unfazed-by-brazils-army-rio-drug-gangs-willing-to-waitout-occupation-idUSKBN1HV1TM>.

${ }^{31}$ Front Line Defenders. 2017. Annual Report on Human Rights Defenders At Risk In 2017. Dublin-Brussels, available at $<$ https://www.frontlinedefenders.org/sites/ default/files/annual_report_digital.pdf $>$.

32 "México: ya son 102 los políticos asesinados en poco más de ocho meses de campaña," Nodal, May 29, 2018, available at <https://www.nodal.am/2018/05/ mexico-ya-son-102-los-politicos-asesinados-en-pocomas-de-ocho-meses-de-campana/>.

33 "Shining light on Latin America's homicide epidemic," The Economist, 2018, op. cit.

${ }^{34}$ United Nations World Tourism Organization, UNWTO Tourism Highlights 2017 Edition, available at <https://www.google.com/search?q=UNWTO $\% 20$ Tourism\%20Highlights\%202017\%20Edition\&cad=h>; Kirk Semple, "Where Tourism Thrives in Mexico, Bloodshed and Poverty Are Blocks Away," The New York Times, September 16, 2017. https://www.nytimes.com/2017/09/16/ world/americas/los-cabos-mexico-crime-tourism.html; Elaine Glusac, "Despite Violence, Tourism Is Strong in Mexican Resort Areas," The New York Times," April 27, 2018., available at <https://www.nytimes.com/2018/04/27/ travel/mexico-tourism-violence.html $>$.

${ }^{35}$ Seguridad, Justicia y Paz. Consejo Ciudadano para la Seguridad Pública y Justicia Penal A.C. 2018. Metodología del ranking (2017) de las 50 ciudades más violentas del mundo. Mexico City, available at <http:// www.seguridadjusticiaypaz.org.mx/biblioteca/prensa/ send/6-prensa/242-las-50-ciudades-mas-violentas-del-mundo-2017-metodologia $>$.

36 "James Beal, "Blood in the Sand," The Sun, April 2, 2018. https://www.thesun.co.uk/travel/5952055/ worlds-most-dangerous-city-beach/; Kirk Semple, "Los Cabos: un paraíso para los turistas; un infierno para sus habitantes," The New York Times, September 18, 2017, available at $<$ https://www.nytimes.com/es/2017/09/18/ violencia-los-cabos-mexico-turismo/>.

${ }^{37}$ Noe Zavaltea, El infierno de Javier Duarte. Mexico 
City, 2016, chapter 5 .

${ }^{38}$ The strategic decisions guiding whether cartels increase or decrease levels of violence are multiple and complex. See Benjamin Lessing,, op. cit., 2015.

${ }^{39}$ Number of people registered until April 30, 2018 by Mexico's National Registry for Missing or Disappeared Persons (Registro Nacional de Datos de Personas Extraviadas o Desaparecidadas, RNPED), available at $<$ http://secretariadoejecutivo.gob.mx/rnped/estadisticas-fuerocomun.php $>$.

${ }^{40}$ International Crisis Group, "Veracruz: Fixing Mexico's State of Terror," Latin America Report, No. 61, February 28, 2017, Mexico CityBogotá-Brussels, 1, available at <https://www. crisisgroup.org/latin-america-caribbean/ mexico/61-veracruz-fixing-mexicos-state-terror $>$.

${ }^{41}$ John P. Sullivan "Chapter 10: How Illicit Networks Impact Sovereignty", in Convergence: Illicit Networks and National Security in the Age of Globalization, ed. Michael Miklaucic and Jacqueline Brewer (Washington, D.C.: NDU Press, 2013), 171-87.

${ }^{42}$ Agustina Giraudy, A. 2010. "The Politics of Subnational Undemocratic Regime Reproduction in Argentina and Mexico." GIGA Journal of Politics in Latin America, Vol. 2, No. 2, 54.

${ }^{43}$ Ibid.

${ }^{44}$ For more on this see Edward L. Gibson, "Boundary Control: Subnational Authoritarianism in Democratic Countries., World Politics, Vol. 58, No. 1, (2015), 101-32.

${ }^{45}$ International Crisis Group, op. cit., February 28, 2017,8 .

${ }^{46}$ Maureen Meyer and Gina Hinojosa, Mexico's National Anti-Corruption System: A Historic Opportunity in the Fight against Corruption, May 17, 2018. Washington, D.C., available at < https://www.wola.org/wp-content/ uploads/2018/05/ENGL-Corruption-Report.pdf>.

${ }^{47}$ International Crisis Group, op. cit., February 28, 2017, 1.

${ }^{48}$ Noé Zavaleta, “Grave deuda” de justicia para periodistas asesinados y desaparecidos en Veracruz: CEAPP”, Proceso, June 7, 2018, available at < https://www.proceso. com.mx/537484/grave-deuda-de-justicia-para-periodistas-asesinados-y-desaparecidos-en-veracruz-ceapp $>$.

${ }^{49}$ International Crisis Group, op. cit., February 28, 2017, 14.

50 "El informe que indica que la parapolítica no es cosa del pasado," Revista Semana, April 17, 2016, available at <https://www.semana.com/nacion/articulo/ procuraduria-adelanta-519-investicaciones-por-parapolitica-y-bacrimpolitica/470010>.

${ }^{51}$ International Crisis Group, "Cutting The Links Between Crime And Local Politics: Colombia's 2011 Elections," Latin America Report, No. 37, July
25, 2011, 3-4, available at <https://www.crisisgroup. org/latin-america-caribbean/andes/colombia/ cutting-links-between-crime-and-local-politics-colombia-s-2011-elections>. For more information see: Claudia López Hernández, (ed.). Y refundaron la patria...De cómo mafiosos y políticos reconfiguraron el Estado colombiano. (Bogotá: Corporación Nuevo Arco Iris, 2010).

${ }^{52}$ International Crisis Group, op. cit., June 21, 2018, 15.

${ }^{53}$ Jonathan Watts, "Operation Car Wash: Is this the biggest corruption scandal in history?" The Guardian, June 1, 2017, available at <https://www.theguardian.com/ world/2017/jun/01/brazil-operation-car-wash-is-thisthe-biggest-corruption-scandal-in-history> ; Anthony Faiola, "The corruption scandal started in Brazil. Now it's wreaking havoc in Peru." The Washington Post, January 23, 2018, available at <https:/www.washingtonpost.com/ world/the_americas/the-corruption-scandal-started-inbrazil-now-its-wreaking-havoc-in-peru/2018/01/23/0f9bc4ca-fad2-11e7-9b5d-bbf0da31214d_story. html?utm_term $=.256 \mathrm{c} 3 \mathrm{c} 0 \mathrm{fcc} 98>$.

54 "Violencia en México: por qué en el municipio de Ocampo metieron a la cárcel a todos los policías," BBC Mundo, June 25, 2018, available at <http://www.bbc.com/ mundo/noticias-america-latina-44592026>.

${ }^{55}$ International Crisis Group, op. cit., February 28, 2017, 7.

56 "Durante todo el proceso electoral fueron asesinados 152 políticos," Excelsior, July 11, 2018, available at https://www.excelsior.com.mx/nacional/ durante-todo-el-proceso-electoral-fueron-asesinados-152-politicos/1251535.

57 " 132 políticos asesinados en el actual proceso electoral; la violencia, focalizada a nivel municipal: Etellekt," Aristegui Noticias, June 26, 2018, available at $<$ https://aristeguinoticias.com/2606/mexico/132-politicos-asesinados-en-el-actual-proceso-electoral-la-violencia-focalizada-a-nivel-municipal-etellekt/>; "México: una campaña pasada por sangre y fuego con 120 políticos asesinados," CNN Español, June 25, 2018, available at https:/cnnespanol.cnn.com/2018/06/25/ mexico-violencia-campana-120-politicos-asesinados/>.

${ }^{58}$ Ana Rita Cunha, Luiz Fernando Menezes, and Bárbara Libório. "9 políticos são assassinados por ano no Brasil," Aos Fatos, March 22, 2018, available at < https://aosfatos.org/ noticias/9-politicos-sao-assassinados-por-ano-no-brasil/>.

${ }^{59}$ Juan Albarracín, "Criminalized electoral politics in Brazilian urban peripheries." Crime, Law and Social Change, Vol. 69, No. 4 (2018), 553-75.

${ }^{60}$ Vanessa Barbara, "The Men Who Terrorize Rio," The New York Times, May 22, 201, available at <https:// www.nytimes.com/2018/05/22/opinion/rio-janeiro-terrorize-militias.html >; Ana Paula Pellegrino, Dandara 
Tinoco, Renata Giannini and Robert Muggah, "Rio de Janeiro's militia on the rise (again)," Igarapé Institute, May 22, 2018, available at < https://igarape.org.br/en/ rio-de-janeiros-militia-on-the-rise-again/z>.

${ }^{61}$ International Crisis Group, op. cit., December 19, 2017, 10 .

${ }^{62}$ International Crisis Group interview, government official, San Salvador, November 22, 2017, quoted in: International Crisis Group, op. cit., December 19, 2017, 11.

${ }^{63}$ Ivan Briscoe and Pamela Kalkman , op. cit., 2016; Deterring the Influence of Organized Crime on Elections. Stockholm, International IDEA, available at < https:// www.idea.int/publications/catalogue/protecting-politics-deterring-influence-organized-crime-elections $>$.

${ }^{64}$ Mica Rosenberg and Nate Raymond, "Brazilian firms to pay record $\$ 3.5$ billion penalty in corruption cases," Reuters, December 21, 2016, available at < https:// www.reuters.com/article/us-brazil-corruption-usa/ brazilian-firms-to-pay-record-3-5-billion-penalty-in-corruption-case-idUSKBN14A1QE>;Tomas Besín, "Fiscalía pide indagar a ocho congresistas por Odebrecht," $E l$ Heraldo, November 15, 2017, available at <https://www. elheraldo.co/politica/fiscalia-pide-indagar-ocho-congresistas-por-odebrecht-423622>; "Musa Besaile, también detenido por parapolítica," El Espectador, May 23, 2018, available at <https:/www.elespectador.com/noticias/ judicial/musa-besaile-tambien-detenido-por-parapolitica-articulo-790278>; "Álvaro Ashton, a juicio por parapolítica,” El Espectador, June 1, 2018, available at <https://www.elespectador.com/noticias/judicial/ alvaro-ashton-juicio-por-parapolitica-articulo-792012>.

${ }^{65}$ Camilo Gómez Forero, "Seis lecturas para entender el cartel de la toga," El Espectador, October 1, 2017, available at <https://www.elespectador.com/ node/715926>.

${ }^{66}$ Corporación Latinobarómetro, Latinobarómetro Informe 2017, Buenos Aires, Argentina, available at <http://www.latinobarometro.org/latContents. jsp?CMSID $=$ Datos $>$.

${ }^{67}$ Corporación Latinobarómetro, op. cit., 2017; Pew Research Center, op. cit., 2014.

${ }^{68}$ International Crisis Group, op. cit., March 21, 2018, i.

${ }^{69}$ Bram Ebus, "Militarization and mining a dangerous mix in Venezuelan Amazon," MONGABAY, December 7, 2017, available at <https://news.mongabay. com/2017/12/militarization-and-mining-a-dangerous-mix-in-venezuelan-amazon/>.

${ }^{70}$ International Crisis Group, op. cit., March 21, 2018, 18.

${ }^{71}$ Ibid.

${ }^{72}$ Ana Rita Cunha, Luiz Fernando Menezes e Bárbara Libório , "Guatemala Stumbles in Central America's Anti-corruption Fight," International Crisis
Group, September 1, 2017, available at <https://www. crisisgroup.org/latin-america-caribbean/central-america/ guatemala/guatemala-stumbles-central-americas-anti-corruption-fight $>$.

${ }^{73}$ Center for Latin American and Latino Studies, 2018, "Avances y Desafíos: Informe sobre los primeros dos años de la Misión de Apoyo contra la Corrupción y la Impunidad en Honduras (MACCIH)," CLALS Working Paper Series, No. 16, available at <https://www.american.edu/centers/latin-american-latino-studies/upload/ MACCIH_Spanish_final.pdf >; "La lucha contra la corrupción y la impunidad bajo ataque," Confidencial HN, July 10, 2018, available at < https://confidencialhn.com/la-luchacontra-la-corrupcion-y-la-impunidad-bajo-ataque/ $>$.

${ }^{74}$ Markus Schultze-Kraft, "Making Peace in Seas of Crime: Crimilegal Order and Armed Conflict Termination in Colombia," Crime, Law and Social Change 69, no. 4: 475-96.

${ }^{75}$ Max Fisher, Amanda Taub and Dalia Martínez, "Losing Faith in the State, Some Mexican Towns Quietly Break Away," The New York Times, January 7, 2018, available at < https://ww w.nytimes.com/2018/01/07/world/ americas/mexico-state-corruption.html $>$.

${ }^{76}$ International Crisis Group, op. cit., December 19, 2017.

${ }^{77}$ Observatório da Intervenção, "Cinco Meses de Intervenção Federal: Muito Tiroteio, Pouca Inteligência," July 16, 2018, available at < http://observatoriodaintervencao.com.br/wp-content/uploads/2018/07/ CINCO-MESES.pdf>.

${ }^{78}$ Brian Winter, "System Failure: Behind the Rise of Jair Bolsonaro," Americas Quarterly, Vol. 11, No. 1, available at < http://www.americasquarterly. org/content/system-failure-behind-rise-jair-bolsonaro>; Bruno Carazza, "Will Brazil's Next President Be a Far-Right Nationalist?” Foreign Affairs, July 12, 2018, available at <https://www. foreignaffairs.com/articles/brazil/2018-07-12/ will-brazils-next-president-be-far-right-nationalist $>$.

\section{Photos}

Page 114. Licensed under Creative Commons Attribution 2.0 Generic License. Photo unaltered.

Page 125. Licensed under Creative Commons Attribution-ShareAlike 3.0 Unported License. Photo produced unaltered. 


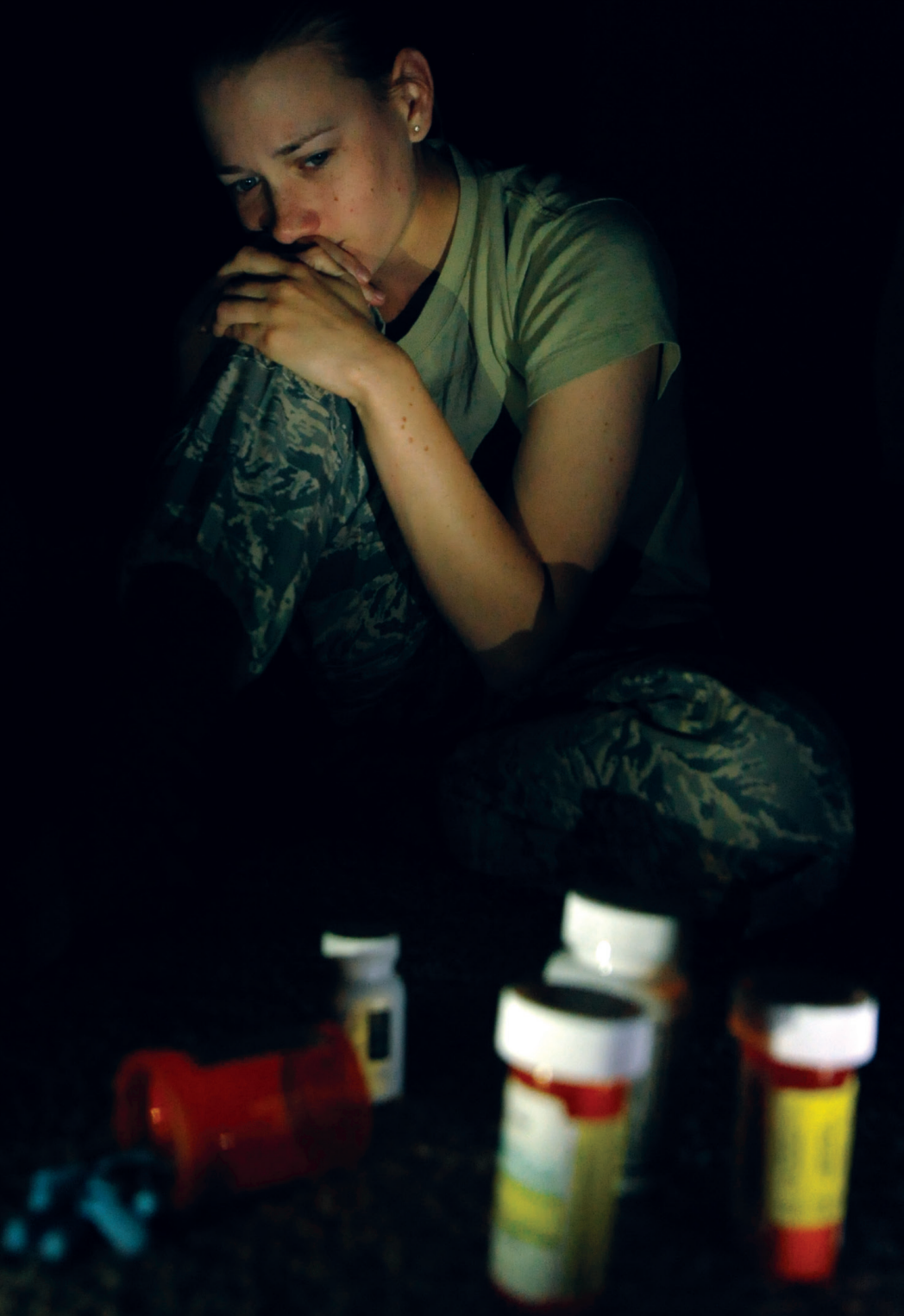

Members of the armed forces are not immune to the substance use problems that affect the rest of society. Most of the prescription drugs misused by service members are opioid pain medications. (U.S. Air Force photo illustration/ Sean Martin) 


\title{
The New Opium War: A National Emergency
}

\author{
By Celina B. Realuyo
}

$\mathrm{F}$ or decades, cocaine was the narcotic of choice in the United States. For decades it drove the so-called "war on drugs" against Colombian and Mexican drug cartels, depicted in films like "Clear and Present Danger" and more recently in the popular Netflix series "Narcos." Narcotics consumption in the United States, however, has recently shifted from cocaine to opioids like heroin and, increasingly, from plantbased to synthetic drugs like methamphetamines and fentanyl.

Heroin use has spread into suburban and rural communities and is growing among most socioeconomic classes, age groups, and races. Potent synthetic opioids like fentanyl have become mixed into black-market supplies of heroin, cocaine, and methamphetamine and are fueling a high-mortality rate, and compounding the crisis. ${ }^{1}$ Unfortunately, U.S. military veterans, many of whom suffer from chronic pain as a result of their service, are twice as likely as the average American to die from a drug overdose involving an opioid. ${ }^{2}$

This crisis is adversely impacting public health, social welfare, the economy, and the national security of the United States. Canada and Mexico are similarly experiencing increased opioid trafficking, use, and addiction. This article will describe the evolution of the opioid trade and epidemic, examine current policies that address supply and demand reduction in the United States and abroad, and advocate the urgent need for more prevention, treatment, and interdiction efforts through interagency, inter-sectorial, and international collaboration.

\section{Opioid Epidemics are not New}

Ancient Egyptians traded opium, then known as the "joy plant," an effective painkiller, throughout the Mediterranean. It is believed that Arab merchants brought it to China in the $7^{\text {th }}$ century. English merchants, led by the British East India Company, from 1772-1850 established extensive opium supply chains to dominate sales in Europe and East Asia, creating the world's first drug cartel. ${ }^{3}$ When the number of Chinese addicts had grown to an estimated 4-12 million by 1838 , the Chinese emperor banned opium. This led to the First Opium War (1839-42) between the United Kingdom and Qing dynasty. The United Kingdom won and forced the Qing Dynasty to allow British merchants to sell Indian-grown opium in China. The opium trade was lucrative, and smoking opium had become quite popular during the $19^{\text {th }}$ century in both Asia and Europe.

Ms. Celina B. Realuyo is a Professor of Practice at the William J. Perry Center for Hemispheric Defense Studies at National Defense University. 
In 1868, the United Kingdom enacted the Pharmacy Act to help curb addiction and death rates by allowing only pharmacists to sell drugs. The Act purportedly reduced the death rate caused by opium from 6.4 per million population in 1868 to 4.5 in 1869 , but after a decade it had risen to more than 5 per million, and by the end of the century it was back at the 1868 level. ${ }^{4}$

In the United States, opium use spread after the Civil War with veterans addicted to morphine as pain relief for their wounds, and Americans consuming opium recreationally in opium dens and medicinally to alleviate coughing and even diarrhea in children. In 1895, the German drug company Bayer introduced a new wonder drug, more powerful than Aspirin, which worked phenomenally well as a cough suppressant, marketed in the United States under the brand name Heroin. Along with cocaine, it was recommended as a safe alternative to morphine for addicts trying to shake their dependency, and flooded the market in many forms.

By the late $19^{\text {th }}$ century opioid addiction was a nationwide crisis, afflicting urban and rural areas and across the country's social classes. The passage of the Pure Food and Drug Act of 1906 forced manufacturers to disclose the contents of their products, so consumers wary of the drug would know if it was in their children's cough syrup. In 1909, Congress passed the Opium Exclusion Act, banning its import for the purpose of smoking.

In 1911, U.S. President Theodore Roosevelt appointed Dr. Hamilton Wright as the nation's first Opium Commissioner. Dr. Wright had led an American delegation to the First International Opium Commission in Shanghai in 1909 and then led another to The Hague in 1912 that produced the first global attempt to regulate narcotics. Wright continued to press for U.S. legislation, despite the objections of drug manufacturers, which resulted in the Harrison Narcotics Tax Act of 1914 that taxed and tightly regulated the sale and distribution of opium and cocaine-based products.

At the peak of the $19^{\text {th }}$ century addiction crisis in 1895, an estimated 300,000 Americans were hooked. ${ }^{5}$ Today the United States has four times as many people but perhaps 10 times as many addicts and the crisis is far more lethal.

\section{Increased Usage and Increased Potency: Dangerous Crossroads}

In 2017, drug overdoses killed an estimated 72,000 Americans-a record number that reflects a rise of about 10 percent over the previous year-according to the Centers for Disease Control and Prevention (CDC). This is a death rate higher than the peak yearly death totals from H.I.V., car crashes, or gun deaths. ${ }^{6}$ Analysts attribute the recent increase to two major causes: a growing number of Americans are using opioids, and drugs are becoming deadlier.

In the late 1990s, healthcare providers began to overprescribe opioid pain relievers after assurances from the pharmaceutical industry- "It's not hypnotic," and "there's no danger of acquiring a habit," - that patients would not become addicted. Opioid pain relievers generally are safe when taken for a short time and as prescribed by a doctor, but because they produce euphoria in addition to pain relief, they can be misused (taken in a different way or in a larger quantity than prescribed, or taken without a doctor's prescription). ${ }^{8}$ Regular use-even as prescribed by a doctor-can lead to dependence and, when misused, opioid pain relievers can lead to addiction, overdose, and potentially death. To satisfy intense cravings, users began purchasing heroin on the black market.

Since 2010, heroin availability in the United States has increased commensurately with the shift by Mexican transnational criminal organizations (TCOs) to heroin and fentanyl trafficking, and reduced poppy eradication efforts in Mexico. Heroin is small in volume and extremely lucrative; much more profitable than marijuana and cocaine. 
Figure 1: Overdose Death Rates Involving Opioids, by Type, United States, 2000-16.

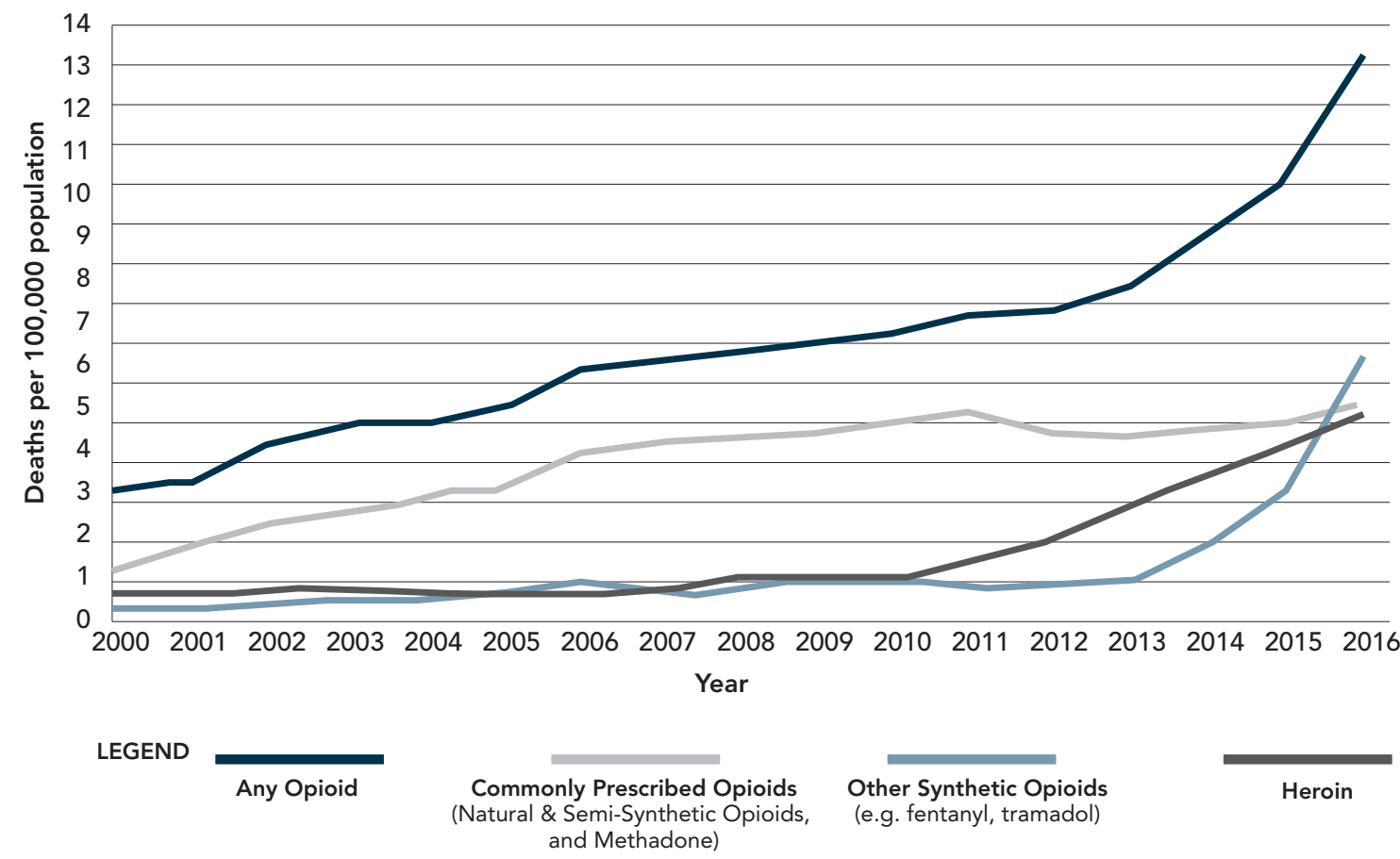

Source: CDC/NICH, National Vital Statistics System, Mortality. CDC Wonder, Atlanta, GA: U.S. Department of Health and Human Services, CDC, 2017, available at <https://wonder.cdc.gov>.

Traffickers can increase their profits and heighten the potency (and the "high") from low-quality heroin by "cutting" it—or mixing it—with fentanyl." Due to its potency - 30 to 50 times that of heroinonly very small amounts of fentanyl are added, but even a small amount can be lethal.

\section{Mexico is a significant source and transit} country for heroin, marijuana, and synthetic drugs including methamphetamine and fentanyl destined for the United States. In 2015, 93 percent of the heroin analyzed entering the United States came from Mexico. ${ }^{10}$ Most opium poppy is cultivated in the Mexican states of Sinaloa, Chihuahua, Durango, and Guerrero where it can be intermingled with other crops and is difficult to detect.

Since poppy has such a short growing cyclefrom seed to harvest in just four months-it is a very efficient crop. ${ }^{11}$ The extracted sap from poppy pods is pressed into a brick-shaped form and then wrapped in cloth or leaves to be sold to a dealer and sent, through the black market, to a heroin-processing facility. Many of these facilities are close to the original fields, because the raw sap is harder to transport and smuggle than the product of the next steps, the morphine base. Heroin laboratories located close to poppy fields are heavily dependent on precursor chemicals coming from China that transform the raw opium from poppy pods into the highly addictive narcotic.

Heroin is not actually produced in the United States, but wholesale quantities of heroin, typically a white or brownish powder, are delivered to the "mill," usually a private home or apartment, where the traffickers break down the heroin into smaller quantities using coffee grinders, blenders, or food processors. They add inexpensive adulterants like caffeine, diphenhydramine, or quinine and diluents such as lactose or mannitol to increase profits. As 
discussed, traffickers can also increase their profits and heighten the potency of low-quality heroin by mixing in fentanyl. In 2016, all Drug Enforcement Administration (DEA) Domestic Field Divisions with white powder heroin markets reported the presence of heroin supplies laced with fentanyl and/ or fentanyl disguised as heroin. ${ }^{12}$

According to the DEA, fentanyl and similar compounds are mostly manufactured overseas and transported to America through the southwest border as in the case of heroin, or through the mail, with Mexico and China serving as the major sources. Based on U.S. Customs and Border Protection seizure data, China is the principal source country of illicit fentanyl and fentanyl-related compounds in the United States, including both scheduled and non-scheduled substances. ${ }^{13}$ Fentanyl analogues and precursor chemicals used to make fentanyl are illicitly manufactured in Chinese labs and then sold on the dark web and shipped in bulk to the United States and Mexico. The anonymity and decreased exposure to law

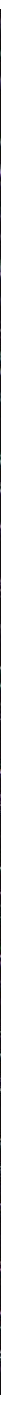

Comparison of a U.S. penny to a potentially lethal dose of fentanyl. (U.S. Drug Enforcement Administration) 
enforcement interdiction make the use of the dark web a preferred method of fentanyl trafficking. Similarly, non-pharmaceutical fentanyl is increasingly being manufactured in Mexico and transported into the United States via well-established Mexican drug trafficking routes.

Since fentanyl emits no odor, it is particularly difficult to detect and interdict. ${ }^{14}$ According to a bipartisan report issued last year by U.S. Senators Rob Portman (R-OH) and Tom Carper (D-DE), studies found that fentanyl sellers in China find it relatively easy to send the drugs through the U.S. Postal Service because "the risk of seizure is small and delivery is basically guaranteed." ${ }^{15}$ In a related statement, Senator Portman said that "We know the depth to which drug traffickers exploit our mail system to ship fentanyl and other synthetic drugs into the United States. . . The Federal Government can and must act to shore up our defenses against this deadly drug and help save lives."

\section{A National Emergency}

In October 2017, President Donald Trump declared the opioid crisis a national Public Health Emergency under federal law and directed all executive agencies to use every appropriate emergency authority to fight the crisis, to include interdiction, treatment, and prevention efforts. In early 2018, President Trump authorized $\$ 6$ billion for opioid crisis programs in the federal budget, with $\$ 3$ billion allocated for 2018 and $\$ 3$ billion allocated for 2019. This crisis does not discriminate based on gender, race, age, economic status, or affect only rural or urban populations. All sectors of society-public, private, and civic-are affected and must take a more active role in countering it through education, prevention, treatment, or interdiction efforts.

\section{That Demands a Whole-of-Community Response}

The White House Office of National Drug Control Policy (ONDCP) aims to reduce drug use and its consequences by leading and coordinating the development, implementation, and assessment of U.S. drug policy. ${ }^{16}$ Working with the Departments of Health and Human Services (HHS) and Justice (DOJ), and other agencies, ONDCP is addressing opioid consumption by promoting community-based drug prevention efforts, detecting early signs of opioid addiction, monitoring prescription drug programs, and increasing access to the opioid-overdose-reversing drug naxalone. ${ }^{17}$

In June the White House, ONDCP, and other partners unveiled a new, multimillion-dollar public awareness campaign aimed at curbing opioid addiction among young people. The first four 30 -second public service announcements illustrate the extreme measures taken by young adults to obtain oxycodone $\left(\right.$ OxyContin $\left.{ }^{\odot}\right)$ and hydrocodone $\left(\right.$ Vicodin $\left.^{\oplus}\right)$-from smashing their hands or arms, to wrecking their cars or even breaking their backs. In speaking about the initiative, White House counselor Kellyanne Conway told reporters:

We hope these ads will spark conversation to educate teens and young adults to talk to their doctors about alternatives to opioids; that pain management may not always mean extended pain medication use; safe disposal practices for leftover, unused prescription; and also, to arm them with specific yet very simple knowledge about opioids. ${ }^{18}$

Other initiatives aimed at curbing drug overdoses have been rolled out at the national level, including expanded access to naxalone, and new opioid prescription guidelines limiting the availability of prescription painkillers. In October, Congress almost unanimously passed and the President signed the Support for Patients and Communities Act that is considered a big breakthrough that will expand access to addiction treatment, enhance law enforcement efforts against the flow of illicit drugs, and combat the over-prescription of opioids. ${ }^{19}$ 


\section{And Requires International Collaboration}

ONDCP is also coordinating with the DOJ, Department of Homeland Security (DHS), Department of State (DOS), and international partners to help disrupt the trafficking of heroin and fentanyl, fentanyl analogues, and precursor chemicals onto U.S. soil. Drug trafficking continues to be the most lucrative illicit activity in the world and a destabilizing force that finances and empowers terrorists and criminal groups. The United States is focusing efforts to reduce drug supplies, like heroin and fentanyl, at their source and dismantle the TCOs that profit from them, particularly in the Western Hemisphere.

The United States is also complementing partner nation efforts to reduce crime and corruption in key drug source and transit countries, and their efforts to professionalize police and other security forces through various foreign assistance programs. These programs also seek to strengthen the rule of law, promote judicial reform, improve information sharing with our law enforcement partners, target criminals and corrupt leaders and disrupt illicit trafficking. The United States and Mexico are working hand-in-hand to address the opioid crisis by stemming the production and flow of heroin and fentanyl into the U.S. market. Meanwhile, the United States is cooperating with Mexico, China, and Canada to address the movement of precursor chemicals and synthetic opioids like fentanyl.

\section{U.S.-Mexico Cooperation}

The Mexican TCOs have capitalized on Mexico's proximity to the United States and Americans' voracious appetite for illegal drugs, traditionally for marijuana and cocaine, and more recently for heroin and opioids. They have dominated the drug trade, and confronted the Mexican municipal, state, and federal governments for decades, and are engaged in a new opium war.

Mexico experienced a record number of homicides in 2017. The Mexican National Institute of Statistics and Geography reported that the country had 31,174 homicides in 2017, an increase of 27 percent compared with 2016, which saw 24,559 homicides. These newly released numbers also show an increase in Mexico's homicide rate to 25 homicides per 100,000 inhabitants nationwide, up from 20 per 100,000 in 2016. Traffickers use violence to settle disputes and control routes and territory; threats of violence maintain employee discipline and a semblance of order with suppliers, creditors, and buyers. The violence in Mexico has escalated astronomically and is now directed toward the government, political candidates, and the news media and not just rival cartels. ${ }^{20}$ Public authorities there estimate that 40 percent of the country is subject to chronic insecurity, with homicidal violence, disappearances, and population displacement at all-time highs. ${ }^{21}$ After a decade of Mexican military deployment on law enforcement missions and continued violence and allegations of human rights abuses, there is a vibrant public debate over the appropriate role of the military and police in the continued fight against TCOs. ${ }^{22}$ The United States and Mexico have one of the most extensive bilateral military and law enforcement relationships in the world. Through the Merida Initiative initiated in 2008, the United States has helped build the capacity of Mexican authorities 
to more effectively eradicate opium poppy, disrupt and prosecute drug production and trafficking, and enhance border security.

The Mexican government eradicates both opium poppy (from which heroin is derived) and cannabis, and it increased its eradication efforts of both plant-based drugs in 2016. Despite these efforts poppy cultivation in Mexico increased to 32,000 hectares (ha) in 2016, from 28,000 ha in 2015, according to the State Department Bureau of International Narcotics and Law Enforcement Affairs. ${ }^{23}$ The U.S. Government estimated that Mexico's potential production of heroin in 2016 totaled 81 metric tons, three times its estimated production in 2013. In 2016, Mexican forces seized roughly 13 metric tons of cocaine, 26 metric tons of methamphetamine, and about 235 kilograms of opium gum, while shutting down 136 clandestine drug laboratories.

In 2018, the Trump Administration intensified its efforts to help Mexico get a more detailed picture of its poppy problem and has begun to supply Mexican authorities with drones and geolocation technology. The Administration is also funding studies to pinpoint how much poppy is being planted and how much heroin is produced from it. ${ }^{24}$

To further broaden cooperation, the United States and Mexico held the first Cabinet-level Strategic Dialogue on Disrupting TCOs in May 2017, to define a new approach to addressing the business model of TCOs, with emphasis on drug production, drug distribution, cross-border movement of cash and weapons, drug demand markets, and illicit revenue. That month, the United States and Mexico also held the first-ever trilateral National Fentanyl Conference for forensic chemists from Mexico, the United States, and Canada to share best practices on the detection, analysis, and handling of fentanyl. The United States also engaged with Mexico and Canada at the 2017 North American Drug Dialogue to produce the first Trilateral Assessment on Opioid
Trafficking. These ongoing dialogues are advancing efforts to disrupt drug trafficking in North America and to end impunity for the TCOs profiting from it.

It is unclear if and how the bilateral cooperation on poppy eradication, interdiction operations, and the fight against the cartels will continue between the United States and Mexico under newly elected Mexican President Andrés Manuel López Obrador (AMLO). He assumed office in December, having won the presidential election in July as a leftist populist with 53 percent of the vote, pledging to fight corruption and end the violence plaguing Mexico. On the campaign trail, AMLO repeated catchy slogans and rhymes to show his opposition to the militarized drug war. These included phrases like "Abrazos no balazos" (hugs, not gunshots), "Becarios sí, sicarios no," (scholars yes, killers no), and "No puedes apagar el fuego con el fuego" (you cannot fight fire with fire). ${ }^{25}$

AMLO is expected to focus more on domestic matters like socio-economic development and anti-corruption rather than on counternarcotics efforts. There is concern that he will adopt the antiU.S. stance that he advocated during his campaign and decrease bilateral cooperation on security matters. ${ }^{26}$ AMLO's new National Plan for Peace and Security (2018-24) diverges from previous Mexican government policies and from U.S. law enforcement and counternarcotics interests. Specifically, the Plan aims to reform the Mexican security services by creating a Mexican National Guard, demilitarizing the conflict with the cartels, consider granting amnesty to drug traffickers, and legalizing marijuana and opium poppy cultivation..$^{27}$

\section{U.S.-China Cooperation}

China is one of the world's top producers and exporters of precursor chemicals and synthetic drugs like fentanyl. The majority of precursor chemical production and export from China is intended for legitimate use; however, precursors and synthetics are being diverted by TCOs and are also 
manufactured in large, sophisticated, illegal factories within China. Chinese criminal organizations traffic illicit drugs domestically and to international markets, and Chinese authorities have noted the presence of international drug trafficking organizations originating from Africa and Mexico operating within the country. China's role as a major international financial center has also fueled an increase in illicit drug and precursor chemical-related money laundering activities.

The United States is cooperating with China to reduce the production and trafficking of illicit fentanyl and fentanyl analogues originating from China through joint law enforcement operations and information-sharing. In 2017, the United States and China regularly shared law enforcement information on new and emerging fentanyl analogues and illegal manufacturing and trafficking activity. For example, DHS and DOJ officials in Hong Kong worked with local customs and law enforcement authorities in 2017 to seize an estimated 50 packages containing fentanyl that were bound for the United States and Canada. ${ }^{28}$ The Bilateral Drug Intelligence Working Group and the Counter Narcotics Working Group, which reports to the U.S.-China Joint Liaison Group on Law Enforcement, also meet annually to exchange views and information on trends in drug abuse and trafficking, discuss pertinent laws, regulations, policies and procedures in the respective countries, address challenges in precursor chemical control, and find mechanisms to cooperate on investigations and cases of mutual interest.

The challenges posed by trafficking synthetics via the internet and small parcel trafficking patterns are formidable and will test the cooperative spirit and ingenuity of the law enforcement authorities in the United States and China. ${ }^{29}$ U.S. law enforcement continues to make inroads in building working relationships with provincial public security bureaus, with oversight by central authorities. ${ }^{30}$ In early
December, on the margins of the G20 Summit in Buenos Aires, President Trump met with Chinese President Xi Jinping, who agreed to designate fentanyl as a controlled substance, meaning that those who sell fentanyl to the United States will be subject to China's maximum penalty under the law-a promising development in efforts to reduce the supply and production of opioids.

\section{U.S.-Canada Cooperation}

Canada is the second largest per capita consumer of prescription opioids in the world after the United States, according to the International Narcotics Control Board. Canadian authorities reported that 65 percent of all analyzed heroin seizure samples tested during the first six months of 2017 contained fentanyl or its analogues. ${ }^{31}$ That year, prosecutors in Canada brought manslaughter charges against drug traffickers accused of selling fentanyl to hundreds of drug users who died as a result of fentanyl overdoses.

Canada is also a supplier of fentanyl, MDMA (ecstasy), and marijuana to the United States, so U.S. agencies cooperate extensively with Canada to enhance regulatory frameworks to prevent access to precursor chemicals and lab equipment for criminal use and stem the flow of illegal drugs across our shared border. Integrated teams of Canadian and U.S. law enforcement authorities operate in several locations along the northern border and the two countries also share information and conduct coordinated operations targeting the trafficking of synthetic drugs, particularly fentanyl and fentanyl precursors. ${ }^{32}$

\section{Conclusion}

Sadly, the current opioid crisis is reminiscent of past periods of addiction and overdose deaths in the United States. The crisis today, however, is on a much larger scale owing to how the American appetite for opioids has changed the nature of the drug trade in North America, from the consumption of marijuana and cocaine to that of heroin and 
fentanyl, and that Mexican TCOs have been quick to capitalize on this demand signal at the expense of record levels of drug-related violence and homicides in Mexico. The opioid epidemic is now a health, security, social, economic welfare, and national security crisis, with some 300 Americans dying from heroin overdoses per week-a rate that contributed to the second straight annual decline in U.S. life expectancy.

The United States Government is doubling down on its prevention, treatment, and supply interdiction measures at the national, state, and local levels to tackle the opioid epidemic. The public, private, and civic sectors must take a more active role in raising awareness of drug abuse and addiction to reduce the demand for opioids, particularly since this opioid epidemic does not discriminate against gender, race, age, economic status, or location. As a transnational crisis, international cooperation to address the supply of illicit opioids is also essential. This whole-of-society approach is required to triumph in the new opium war and overcome this latest opioid epidemic in North America. PRISM

\section{Notes}

${ }^{1}$ Office of National Drug Control Policy, "Prescription Opioid Misuse, Heroin, and Fentanyl," available at $<$ https://www.whitehouse.gov/ondcp/ key-issues/prescription-opioid-misuse/>.

${ }^{2}$ Robert Wilkie, "Fighting Pain and Addiction for Veterans," White House Media Release, October 26, 2018, available at $<$ https://www.whitehouse.gov/articles/fighting-pain-addiction-veterans/>. For additional background see: Claire Felter, "The U.S. Opioid Epidemic Backgrounder," Council on Foreign Relations, December 26, 2017, available at <https://www.cfr.org/backgrounder/ us-opioid-epidemic $>$.

${ }^{3}$ Eric Gutierrez, "Lessons from the Past Could Help Tackle Today's Narcotics Trade," New Internationalist, November 11, 2015, available at $<$ https://newint.org/ blog/2015/11/11/drugs-cartels $>$.

${ }^{4}$ Virginia Berridge and Griffith Edwards, Opium and the People, Opiate Use in Nineteenth-Century England, (New York, Saint Martin's Press: 1982), available at <https://web.archive.org/web/20131225190914/http:// www.druglibrary.eu/library/books/opiumpeople/pharmact.html $>$.

5 "Inside the Story of America's Opioid Addiction," Smithsonian.com, available at $<\mathrm{https}$ ://www. smithsonianmag.com/history/inside-story-americas-19th-century-opiate-addiction-180967673/>.

${ }^{6}$ Margot Sanger-Katz, "Bleak New Estimates in Drug Epidemic: A Record 72,000 Overdose Deaths in 2017," The New York Times, August 15, 2018, available at $<$ https://www.nytimes.com/2018/08/15/upshot/opioids-overdose-deaths-rising-fentanyl.html $>$.

${ }^{7}$ Miroff, op.cit. Opioids are a class of drugs that include the illegal drug heroin, synthetic opioids such as fentanyl, and pain relievers available legally by prescription, such as oxycodone (OxyContin ), hydrocodone (Vicodin ${ }^{\circ}$ ), Codeine, Morphine, and many others.

${ }^{8}$ Opioids are a class of drugs that include the illegal drug heroin, synthetic opioids such as fentanyl, and pain relievers available legally by prescription, such as oxycodone (OxyContin ${ }^{\circledR}$ ), hydrocodone (Vicodin $\left.{ }^{\circledR}\right)$, Codeine, Morphine, and many others.

${ }^{9}$ Leslie Cooley Dismukes, "How Did We Get Here? Heroin and Fentanyl Trafficking Trends, A Law Enforcement Perspective," North Carolina Medical Journal, 79 no. 3 (MayרJune 2018), 181 784 , available at $<$ http://www.ncmedicaljournal.com/content/79/3/181. full $>$. This tragedy has been well depicted in Sam Quinones' powerful book, Dreamland: The True Tale of America's Opiate Epidemic, (Bloomsbury Press, 2015).

${ }^{10}$ U.S. Department of Justice, "National Drug Threat Assessment, 2017" Drug Enforcement Administration, available at $<$ DEA 2017 National Drug Threat Assessment, https://www.dea.gov/sites/default/files/docs/ DIR-040-17_2017-NDTA.pdf >.

${ }^{11}$ Joshua Partlow, "U.S. Has been Quietly Helping Mexico with New, High-tech Ways to Fight Opium," The Washington Post, April 15, 2018, available at $<$ https://www.washingtonpost.com/world/ the_americas/us-has-been-quietly-helping-mexicowith-new-high-tech-ways-to-fight-opium/2018/04/15/ dc18eda0-26d5-11e8-a227-fd2b009466bc_story. html?noredirect $=$ on\&utm_term $=.89 \mathrm{e} 2 \mathrm{fa} 6 \mathrm{be} 902>$.

${ }^{12}$ U.S. Department of Justice "National Drug Threat Assessment." The DEA does not just interdict illegal narcotics and reduce drug flows but is also actively engaged in education and prevention programs. DEA's 360 Strategy to combat heroin/opioid use issued on November 10, 2015 has three main goals: stopping the deadly cycle of heroin and opioid pill abuse by eliminating drug trafficking organizations and gangs fueling violence on the streets and cycles of addiction in our communities; partnering with the medical community and public 
to raise awareness of the dangers of prescription opioid misuse and conducting the National Prescription Drug Take Back Day for Americans to safely dispose of any unwanted, unused or expired prescription medications and strengthening community organizations best positioned to provide long-term help and support for building drug-free communities.

${ }^{13}$ U.S. Department of State "2018 International Narcotics Control Strategy Report,” Bureau for International Narcotics and Law Enforcement Affairs, available at $<$ https://www.state.gov/documents/organization/278759.pdf $>$.

${ }^{14}$ Ibid.

${ }^{15}$ Madeline Mitchell, “This Drug-busting Agency has More Power than the DEA, but We Can't Tell How They Use It," Cincinnati Enquirer, August 18, 2018, available at <https://www.cincinnati.com/story/news/crime/ oh-crime/2018/08/13/drugs-mail-how-postal-servicefighting-drugs-cincinnati-mystery/673509002/> The top priority of the U.S. Postal Inspection Service is protecting the U.S. Mail and its consumers. According to the U.S. Postal Service, inspectors seized more than 40,000 pounds of illegal drugs along with $\$ 22,487,980$ from packages, resulting in 1,954 arrests in 2017.

${ }^{16}$ White House Office of National Drug Control Policy, "Mission Statement," available at<https://www. whitehouse.gov/ondcp/>.

${ }^{17}$ Ibid.

${ }^{18}$ The 30-second ads, reminiscent of Nancy Reagan's "Just Say No" Campaign, were produced in partnership with the Truth Initiative, the Ad Council, and the White House Office of National Drug Control Policy will air on television and digital platforms. The ad funding mostly came private partners, including Facebook, Google, YouTube, NBC, Amazon, VICE, and Turner.

${ }^{19}$ German Lopez, “Trump Just Signed a Bipartisan Bill to Confront the Opioid Epidemic," Vox.com, October 24, 2018, available at <https://www. vox.com/policy-and-politics/2018/9/28/17913938/ trump-opioid-epidemic-congress-support-act-bill-law $>$.

${ }^{20}$ U.S. Library of Congress, Congressional Research Service, Mexico: Organized Crime and Drug Trafficking Organizations, by June S. Beittel, R41756 (July 3, 2018), available at $<$ https://fas.org/sgp/crs/row/R41576.pdf $>$.

${ }^{21}$ Robert Muggah and John P. Sullivan, "The Coming Crime Wars," Foreign Policy, September 21, 2018, available at <https://foreignpolicy.com/2018/09/21/ the-coming-crime-wars/ $>$.

${ }^{22}$ Christopher Woody, "After a Decade Fighting the Cartels, Mexico May be Looking for a Way to Get its Military Off the Front Line," Business Insider, February 13, 2017, available at <http://www.businessinsider.com/ mexican-military-role-in-fighting-drug-war-and-cartels-2017-2>.

${ }^{23}$ U.S. Department of State "2018 International Narcotics Control Strategy Report,” 221.

${ }^{24}$ Joshua Partlow, "U.S. has Been Quietly Helping Mexico with New, High-tech Ways to Fight Opium," The Washington Post, April 15, 2018, available at <https://www.washingtonpost.com/world/ the_americas/us-has-been-quietly-helping-mexicowith-new-high-tech-ways-to-fight-opium/2018/04/15/ dc18eda0-26d5-11e8-a227-fd2b009466bc_story. html?noredirect=on\&utm_term $=.89 \mathrm{e} 2 \mathrm{fa6be} 902>$.

${ }^{25}$ James Fredrick, "Mexico's New President has a Radical Plan to End the Drug War," Vox, August 15, 2018, available at <https://www.vox.com/2018/8/15/17690420/ mexico-president-amlo-drug-war-cartels-violence-legalization>.

${ }^{26}$ U.S. Library of Congress, 7.

27 "Los 8 Ejes del Plan Nacional de Paz y Seguridad de AMLO" [The 8 Axes of AMLO's National Peace and Security Plan]," El Financiero, November 14, 2018, available at <http://www.elfinanciero.com.mx/nacional/ los-8-ejes-del-plan-nacional-de-seguridad-y-paz-de-amlo $>$.

${ }^{28}$ DHS involvement included Immigration and Customs Enforcement (ICE) and Homeland Security Investigations (HSI), whereas DOJ involvement included the Drug Enforcement Administration (DEA). U.S. Government Accountability Office (GAO), Illicit Opiods: While Greater Attention Given to Combating Synthetic Opioids, Agencies Need to Better Assess their Efforts, GAO1825, Washington D.C., March 2018, available at <https:// www.gao.gov/assets/700/690972.pdf>.

${ }^{29}$ Ibid.

${ }^{30}$ Ibid.

${ }^{31}$ U.S. Department of State "2018 International Narcotics Control Strategy Report,” 131.

32 These include Border Enforcement Security Taskforces (BEST), Integrated Border Enforcement Teams (IBET), and the Integrated Crossborder Maritime Law Enforcement Operations (aka "Shiprider"); see also the U.S. Department of State "2018 International Narcotics Control Strategy Report.” 


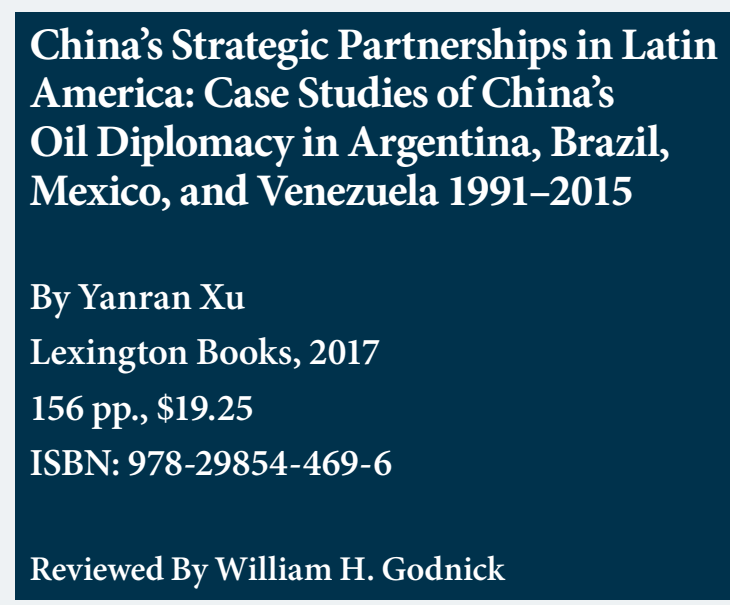

$\mathrm{I}$ n 2011, the Peruvian drug czar appointed by incoming President Ollanta Humala announced that U.S.-supported coca eradication was suspended in favor of locally-based alternative development and targeted efforts to dismantle organized crime rings. The American Embassy was not consulted on this decision and it took several days before the U.S. Ambassador could get a formal briefing from the Peruvian government. ${ }^{1}$ This would have been unthinkable several years earlier. ${ }^{2}$ More recently, U.S Defense Secretary James Mattis, during a tour of four South American countries this August, expressed serious concern about growing Chinese influence in Latin America and issued a warning to partner nations about the risk of losing their sovereignty. ${ }^{3}$

However, the conditions encountered by Secretary Mattis during his trip are a natural result of the convergence of factors including the attention devoted by the U.S. defense and national security enterprise to other parts of the world, the relatively diminished level of American soft power due to the 2008/2009 financial crisis, and the emergence of China as South America's most important trading partner. Yanran Xu's book, China's Strategic Partnerships in Latin America, addresses this third factor through an examination of the Chinese government's strategic partnerships and oil diplomacy in three South American countries and Mexico.

As a trilingual (English, Spanish and Mandarin Chinese) lecturer at the School of International Studies at Renmin University of China, Xu provides unique insights and sourcing. The book probably is best categorized within the field of international political economy (IPE) with its use of official government statistics and statements as well as a detailed secondary literature review. While the work understandably departs from some of the more suspicious views on China's presence in Latin America put forth by authors such as R. Evan Ellis at the U.S. Army War College, it is by no means an uncritical examination of China's policies toward the Western Hemisphere. ${ }^{4}$

The primary focus of the book is examining the impact of China's "Going Out Policy" (also referred to as Going Global Strategy) initiated in 1999 and consolidated globally and regionally in Latin America and the Caribbean during the course of the past two decades. Xu does this using the case study method, in particular looking at China's investments in and purchases of oil from Argentina, Brazil, Mexico and Venezuela. It also places China's engagement in the context of the One China Policy taking into consideration that half of the countries that maintain official diplomatic relations with Taiwan are found in Latin America and the Caribbean, even if those numbers are dwindling. Only as recently as August, the Central American republic of El Salvador changed its allegiance from Taiwan to mainland China. ${ }^{5}$ In resource rich South America, only Paraguay maintains official diplomatic relations with Taiwan.

While not good literature in the novelistic sense, $\mathrm{Xu}$ walks the reader through a clear and understandable research methodology based on the testing of four hypotheses paraphrased here. First, if a country

Dr. William H. Godnick is a Professor of Practice at the William J. Perry Center for Hemispheric Defense Studies at National Defense University. 
is an ally of the United States its economic relations with China will be more balanced (realist). Second, if a country is economically interdependent with China its economic relations will also be balanced (IPE). Third, if a country is more economically diversified it is more likely to get a balanced deal from China (dependency theory). Fourth, if a country is left-leaning it will get a more balanced deal from China economically speaking (constructivist).

There is not sufficient space in this review to comprehensively summarize the author's detailed findings for each of these hypotheses. Nonetheless, it useful to note that a number of the more general findings. First, China's strategic investments and oil diplomacy generate important short-term economic benefits to governments in power, though the commercial relationships that emerge tend to undermine local industries making it difficult to compete with Chinese imports over the medium and long terms. Second, while the Chinese government is happy to be a thorn in the side of U.S. hegemony in Latin America it is careful not to cross any red lines and acts more cautiously in countries geographically closer to the United States. Third, Venezuela represents a problem for China but the natural resource access and political benefits that problem creates in stifling the U.S. political and military positions in Latin America outweigh any costs incurred to date.

According to Xu's framework Brazil, under the two governments of the Workers Party met the second and third criteria, being economically interdependent with China, having the region's most diversified economy and being governed by left-leaning governments, all suggesting that Brazil's strategic partnership is more balanced than not. She points to the fact that Brazil not only exports primary products, but has more developed technologies of interest such as those related to hydro-power and aviation. As Brazil appears to have tilted more rightward, at least in the near-term, it is not clear how Xu thinks this will affect the balance in the strategic partnership.

On the other hand, Venezuela only meets two of the element of Xu's framework, being economically inter-dependent and being governed by a left-leaning government. However, Xu's analysis shows there is more than meets the eye in regards to the Bolivarian government's strategic partnership with China. First, while still engaged in hostile bilateral politics, nearly half of all Venezuelan oil still goes to the United States. Second, through Venezuela's Petrocaribe alliance, China benefits from the oil diplomacy exercised with the numerous Caribbean islands through their votes in the United Nations General Assembly and the Organization of American States even in cases where these island nations maintain diplomatic relations with Taiwan. $\mathrm{Xu}$ points out that for Venezuela the strategic partnership is tilted heavily in China's favor through ownership of current and future oil production. What is less clear is how much of the evolving Venezuelan crisis the Chinese will own.

Xu's analysis of Argentina was completed just as the right of center government of Mauricio Marci took power. Her framework analyzes the two Kirchner governments' strategic partnerships with China: highly inter-dependent with China in terms of soybean and petroleum exports and a left-leaning government. ${ }^{6}$ Argentina is a relatively diversified economy, but not in terms of its exports. Her analysis suggest that China has a strong upper hand in the relationship, evidenced by the inability of the current Macri government to shut down a Chinese satellite station set up by the previous government fearing retaliation by China withcommodities exports. ${ }^{7}$

Finally, Mexico appears to have the most balanced strategic partnership with China due to its interdependence with the United States, though the China falls well behind the United States and Canada as a top trading partner. What China sees in Mexico, according to $\mathrm{Xu}$, is geographical proximity to the U.S. 
market and the ability to use Mexico as an export and trading platform to North America. In essence, Mexico has a balanced, but small strategic partnership with China lacking the interdependence and ideological affinity though this may change once Manuel Lopez Obrador takes power at the end of this year.

China's Strategic Partnerships in Latin America only discusses issues of military cooperation in passing. This makes sense in that Chinese military cooperation and arm sales to Latin America are limited, most notably the case of the satellite facility in Argentina. In stark contrast to Russia's interest in Latin America, the arms trade is a relatively minor part of China's economic ties with the region. While it has always probably been the case in one way or another, geostrategists increasingly look at the interaction of military and security concerns with the economic, technological, social, and environmental spheres. This raises a number of questions, to include how the U.S. Government decision in 2017 to withdraw from the Trans-Pacific Partnership that economically unites North and Latin America with the Asia-Pacific regions will affect the American defense and security postures in the Western Hemisphere. Ten former U.S. combatant commanders in March 2018 expressed their concern for this decision in a letter to President Trump, which suggests the debate about the relationship between legitimate domestic economic concerns and national security continues. ${ }^{8}$ Will it be possible for the United States to compartmentalize economic and security issues globally and within Latin America in the face of growing economic and political bonds with China? Will China's developing defense industry, unattached to criteria on good governance and human rights, eventually become more attractive to Latin American governments?

China's gains in Latin America achieved through strategic partnerships and oil diplomacy are probably an inevitable result of the country's unprecedented economic growth and need for commodities.
However, the relative reduction in U.S. influence is largely a result of inattention and the lack of a coherent strategy for the Western Hemisphere within the U.S. official strategic community. Xu's book, unsurprisingly, demonstrates that the Government of China takes a longer view on these issues showing a willingness to accept short-term difficulties in the name of longer-term objectives. PRISM

\section{Notes}

${ }^{1}$ Colletta A Youngers, "Peru Sends Mixed Signals on Drug Policy," World Politics Review, June 16, 2014, available at <https:// www.worldpoliticsreview.com/articles/13860/ peru-sends-mixed-signals-on-drug-policy>.

${ }^{2}$ It should be noted that the Peruvian government returned to the status quo in 2012 in large part towing to pressure by the armed forces to avoid losing ground to narco-insurgent groups such as the Shining Path.

${ }^{3}$ Martin Arostegui, “James Mattis: Latin American Countries Selling out their Sovereignty to Russia and China," Washington Times, August 16, 2018, available at $<$ https://www.washingtontimes.com/news/2018/aug/16/ james-mattis-south-american-countries-selling-sove/>.

${ }^{4}$ See Robert E.Ellis, The Strategic Dimension of Chinese Engagement with Latin America, Perry Paper Series No. 1,(William J. Perry Center for Hemispheric Defense Studies: Washington DC, 2013).

${ }^{5}$ Yimlou Lee and Phillip Wen, "Tawain Says China 'out of control' as it Loses El Salvador to Beijing," Reuters, August 20, 2018, available at $<<\mathrm{https://}$ www.reuters.com/article/us-taiwan-diplomacy/ taiwan-says-china-out-of-control-as-it-loses-el-salvadorto-beijing-idUSKCN1L6058>.

${ }^{6}$ Nestor Kirchner, served as President from 2003-07 but did not run for reelection, and was proceeded by his wife, Christina Fernandez de Kirhcner, who was elected in 2007 and served as President of Argentina until 2015.

${ }^{7}$ Arostegui.

${ }^{8}$ General Bantz J. Craddock, Commander SOUTHCOM (2004-06) and Former SOUTHCOM and NORTHCOM Commanders, et.all, March 15, 2018.

Letter, Inside Defense, available at $<$ https://insidedefense. com/document/former-northcom-southcom-commanders-letter-trump-nafta>. 

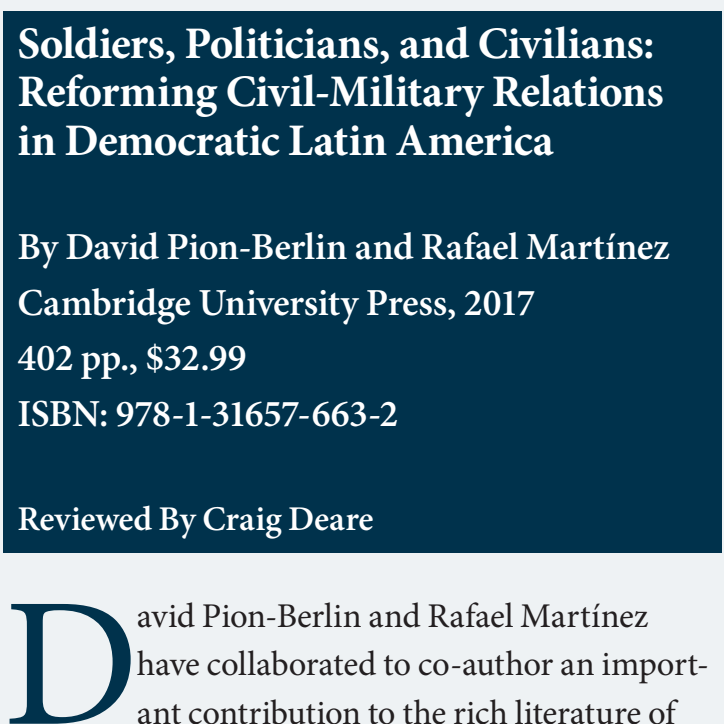
avid Pion-Berlin and Rafael Martínez have collaborated to co-author an important contribution to the rich literature of civil-military relations in Latin America. Both are well-known scholars in this specific field: Their partnership in this project adds another contribution with an emphasis on what they term "a multidimensional approach" to "examining what is a complex set of relations between soldiers, politicians, and civilians." As they acknowledge at the outset of the book, the civil-military relations field is extensive, and is pursued from a number of angles, "perhaps too many."

Although the study of civil-military relations was launched with the late Samuel Huntington's classic The Soldier and the State in 1957, research on the theme of Latin America began in earnest in the 1980s as the transitions from authoritarian rule to democratic governments were underway. Part of the civil-military relations challenge stems from the basics: What is the question? From the Spanish conquest in the 16th century, through the independence movements of the 19th century, continuing through today, Latin American political history has been heavily affected by the strained relationship between society and its political system with the military. In the post-1980s environment, scholars have examined a variety of issues regarding the role of the military in democracy, including (among others) the structures of military regimes, the role of the military in the transition to democracy, civilian control over the military, institutional reforms (such as the creation of and/or reforms of defense ministries), security sector reform, and militarization of internal security. That said, the civil-military relations conversation is typically linked to the discussion of democratic breakdown, authoritarianism, democratization, and democratic consolidation. It is squarely within this discussion-democratization and consolidation - that Pion-Berlin and Martínez engage.

Their purpose is to "contemplate what the entire complex of civil-military relations looks like" in order to lead to military reform "so that it compliantly services the democratic state." In particular, they seek to examine the "triangular relations between solders, politicians, and society." More on this later. To assess civil-military relations, their research examines four countries in South America: Argentina, Brazil, Chile, and Uruguay. Pion-Berlin and Martínez use these four because of geographical proximity, a similar low-risk environment, and a shared history of diplomatic settlements, treaties, and economic consensus. They also note that the four countries all experienced military authoritarian rule in the 1960s and 1970s, and began their transitions away from those regimes in the 1980s.

Pion-Berlin and Martínez broaden their analysis by establishing their "multidimensional" framework around six variables: power, law, institutions, knowledge, values, and performance. Further structure is provided through the disaggregation of these six "dimensions" into 25 components, and an additional five sub-components. The book is organized around chapters that analyze each of these dimensions and components sequentially, examining each country in terms of how it has evolved over

Dr. Craig Deare, a former U.S. Army Latin America Foreign Area Officer, is the Chair, Department of Strategic Initiatives and Leadership at National Defense University's College of International Security Affairs. 
time employing that specific lens. Prior to doing so, however, the first chapter explains the elements of the framework and its relation to the broader political system. The second chapter undertakes the task of establishing the larger historical environment in which each of the four countries developed their individual civil-military relationships, and is a very useful overview.

Pion-Berlin and Martínez undertake their very ambitious task with great attention to detail, and the book is filled with excellent historical evidence and valuable analysis. Each chapter systematically examines the cases of Argentina, Brazil, Chile, and Uruguay-in that order-through an assessment of progress from "authoritarian to full-fledged democratic rule" using "ordinal-ranked benchmarks for success (none, little, moderate, and substantial)." This methodology is innovative and laudable, and provides an excellent structure with which to assess the evolution of the progress toward more effective civilian control, which Pion-Berlin and Martínez posit is the process by which to move an authoritarian institution into one which is democratically abiding. As they argue, the key is to devise "a system that assures that this non-democratic entity falls in line with the decisions made by its executive overseers, whether it wants to or not, and whether it agrees with the policies or not." The challenge, of course-as it is with themes that are difficult to quantify-is the difficulty of accurately evaluating the inherently idiosyncratic nature of the themes; the evaluation of whether the progress is none, little, moderate, and substantial, however objective the intent, remains subjective at the end of the day.

The net result of their extensive analysis is that the "average level of progress achieved for all the dimensions and countries is 1.9 , which means slightly less than moderate gains." They note that over 60 percent of all their established dimensions are either in a transition or consolidation phase; only 36 percent have been fully consolidated (and the majority of that consolidation is in Argentina). Pion-Berlin and Martínez conclude that it "should not be surprising that much more work needs to be done in reforming CMR across the four nations." The key findings that I took away from their analysis are these: the importance for politicians and their appointed civilians to conduct military reform through a civil-military relations construct; to step in and assume their proper roles with regard to strategy development and assessment; and to find ways to incentivize their legislatures to play a stronger institutional authorization and oversight role.

Despite a very-well researched and beautifully written volume, I continue to have reservations with the bias of much of the literature, which this volume supports. As a retired military officer, and based on decades of interacting with military professionals throughout the region, I view the literature from a different perspective than many of the scholars in the field. The very title of the PionBerlin and Martínez book-Soldiers, Politicians, and Civilians - betrays the prevailing bias. The continuing presence of the armed forces performing internal security functions throughout the region is the unintended consequence of democratically elected politicians' (and their appointed subordinates) collective failure to strengthen civilian institutions across the board. More fundamentally, the low esteem in which politicians and political parties (the executive) and the legislative authorities are routinely ranked (at the very bottom of regional surveys) strongly suggests that most societies have failed to develop institutions capable of delivering effective governance. A large segment of the literature tends to stress the military's role in the civil-military relations milieu, implicitly implying that the civilians and politicians bear lower levels of responsibility; I dissent from that view. Soldiers, Politicians, and Civilians is not-in my view-the correct order to assess the quality of civil-military relations; rather, Civilians, Politicians, and Soldiers, 
in that order, makes more sense in terms of who should be held to account for the state of play. After all, both politicians and soldiers were civilian members of their societies before embarking on their chosen professions, and for that reason the examination must begin with the society itself.

Pion-Berlin and Martínez are clearly supportive of the Soldiers, Politicians, and Civilians perspective of how the debate should be structured. As they note, "What is critical to democratic governance is the need to reduce the military's political clout," and "The ultimate goal for a democracy is to irreversibly transform the armed forces into an administrative instrument of the state." While it is without dispute that a nation's armed forces should indeed be "instruments of the state," I would argue that this is not the "ultimate goal for a democracy." And although I do not minimize the importance of ensuring the military has no political clout, this is to confuse cause and effect. That is to say, the extent to which the military has any degree of clout is the net effect of a society's failure to create structures and processes by which the political class effects governance; the residual clout is the unintended consequence of the absence of strong, effective, and honest political leadership. Effective democratic governance is a function of many interrelated factors, but I would submit that a reduced level of military clout is not at the top of the list. Indeed, Pion-Berlin and Martínez would appear to acknowledge this to some degree: "After all, civil-military transformations do not occur in isolation; they exist within and are shaped by the larger democratic system of which they are a part."

My other concern with the Pion-Berlin and Martínez contribution has to do with what I assess to be a very ambitious and yet not terribly helpful comparison between their choice of cases. The model (perhaps with some additional refinement from other scholars) could prove to be a useful yardstick of sorts with which to generate some type of coherent comparative analysis. That said, comparing four countries as different as Argentina, Brazil, Chile, and Uruguay leaves one with a bit of a "So what?" sensation. As Pion-Berlin and Martínez themselves acknowledge, "This Latin American Southern Cone subregion has provided, in a sense, a difficult test for CMR reforms because of the very low-threat security environment." Although they make a persuasive case that studying this subregion has certain advantages, as one looks at the current levels of insecurity across Latin America and the roles being played by various countries' militaries, the case selection (with the exception of Brazil) may seem less important than those of Colombia, Nicaragua, Venezuela, or Mexico (to name only a few). As most regional specialists acknowledge, each individual country has its own unique set of challenges and opportunities.

That said, the net takeaway of the Pion-Berlin and Martínez project is a well-researched, thoughtfully constructed, highly informative, and most readable contribution to the extensive civil military relations literature. Any student or scholar interested in the ongoing discussion of the role of the armed forces in Latin America should have this volume on their bookshelf. PRISM 


\section{SUBSCRIPTIONS}

Keep up to date with global and national security affairs, including sources, effects, and responses to international insecurity, global policy and development, nation-building and reconstruction, counterinsurgency, and lessons learned. To request your journal of complex operations, contact the PRISM editorial staff at $<$ prism@ndu.edu $>$. Please include your preferred mailing address and desired number of copies in your message. 
(10)
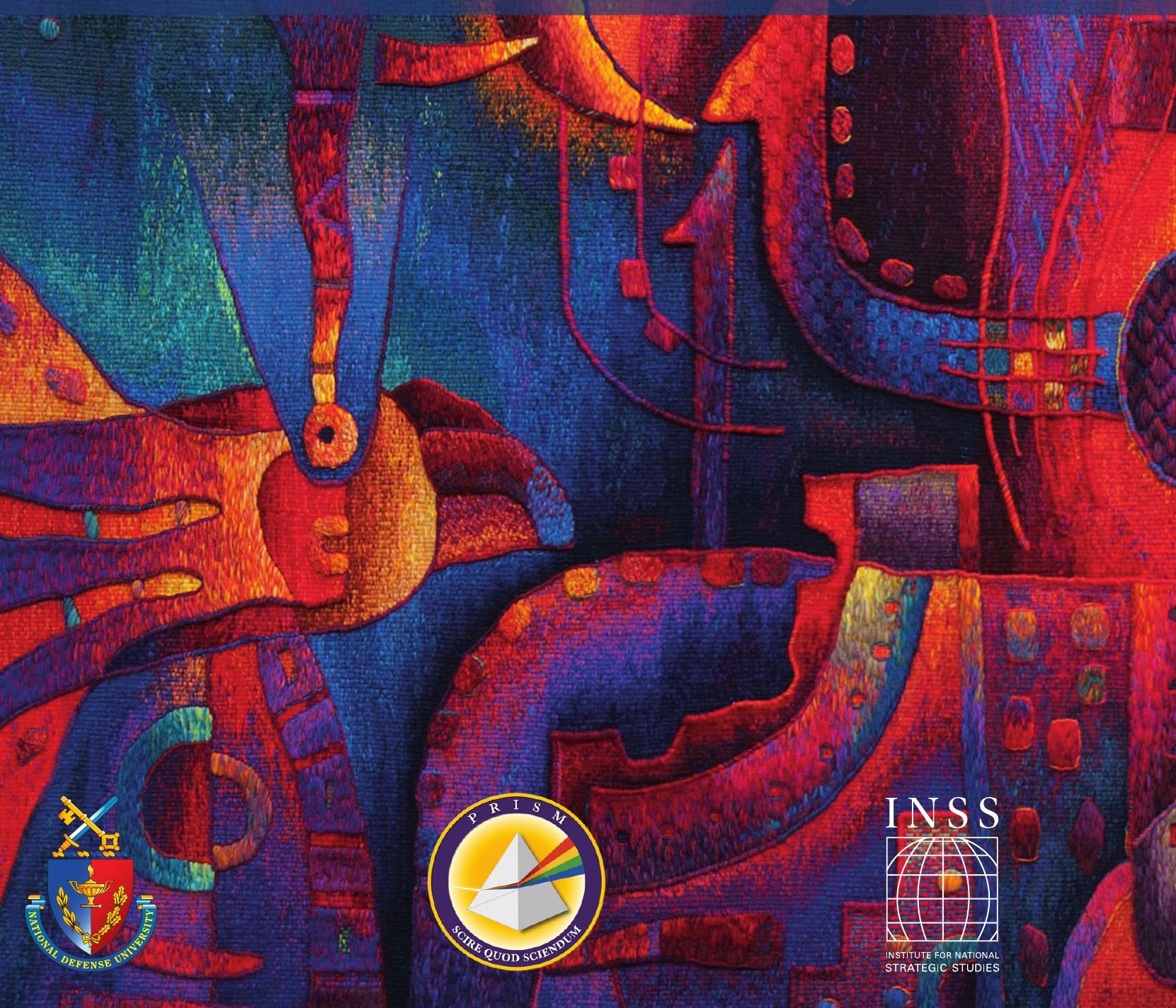

2. 